POLIANA AVELAR GUIMARÃES

ESTUDO DA ADERÊNCIA ENTRE CAMADAS ASFÁLTICAS DE PAVIMENTOS 
POLIANA AVELAR GUIMARÃES

\section{ESTUDO DA ADERÊNCIA ENTRE CAMADAS ASFÁLTICAS DE PAVIMENTOS}

Dissertação apresentada à Escola Politécnica da Universidade de São Paulo para obtenção do Título de Mestre em Engenharia.

Área de Concentração:

Engenharia de Transportes

Orientadora: Profa. Dra. Kamilla Lima Vasconcelos 
Este exemplar foi revisado e alterado em relação à versão original, sob responsabilidade única do autor e com a anuência de seu orientador.

São Paulo, de fevereiro de 2013.

Assinatura do autor

Assinatura do orientador

\section{FICHA CATALOGRÁFICA}

Guimarães, Poliana Avelar

Estudo da aderência entre camadas asfálticas de pavimentos / P.A. Guimarães. -- ed.rev. -- São Paulo, 2013. $189 \mathrm{p}$.

Dissertação (Mestrado) - Escola Politécnica da Universidade de São Paulo. Departamento de Engenharia de Transportes.

1. Pavimentos flexíveis 2. Asfalto I. Universidade de São Paulo. Escola Politécnica. Departamento de Engenharia de Transportes II. t. 
Ao meu pai, meu sorriso.

À minha mãe, meu orgulho. 


\section{AGRADECIMENTOS}

Agradeço a todos aqueles que, de alguma forma, contribuíram para o desenvolvimento deste trabalho. Seja com palavras de apoio, com uma pipoca no meio da madrugada ou um café depois do almoço. São muitas as pessoas que fizeram parte desta minha jornada.

Em primeiro lugar, à minha mãe que sempre nos incentivou a estudar e buscar o conhecimento como uma forma de enxergar além. Aos meus irmãos Túlio, Paulo e Taís. À tia Bia, João Pedro, Caroles e Buruno, meu segundo lar. Ao Adriano, por segurar a minha mão nas melhores e nas piores horas. À família, que sempre foi a minha base e a todos os amigos, que souberam lidar com essa fase ausente da minha vida, e se fizeram presentes, mesmo com a distância.

Ao Márcio Belluomini, por ser o idealizador desse sonho e aos queridos Liedi Bernucci e José Carlos Valsecchi por possibilitarem sua realização.

À ARCADIS Logos, pelo incentivo. Aos companheiros do dia a dia, Daniela, Osvaldo, Marta, Pamela, Adriana, Bruno, Ana Cândida, Flavinha, Belisa, Clarissa, Rafa, Hugo"s", SidneyOno e Mari. Um "muito obrigada" pelo apoio, paciência e compreensão. Vocês sabem o quanto foram importantes para que esse trabalho se consolidasse e sempre terão um lugar especial na minha vida.

Ao pessoal do LTP e da EPUSP. Em especial à preciosa "Kamis, mamis, mamãe", muita admiração e carinho, por cada gargalhada, cada desespero, cada braço dado daquele jeitinho que só uma mãe cuida de um filho. À professora Liedi (novamente) por toda atenção e palavras de apoio ao longo desses dois anos. Ao Erasmo, que é quase um sócio desse trabalho. Ao Kendi, pela ajuda infinita. E a todos que fizeram parte das "terças-feiras": Dio, Ed, Robson, Vanderley, Rô, Mateus, John, Márcia, Igor, Antônio, Daniel, Cláudio, Tiago, Sérgio, Amanda, Ana, Manu, Rodrigo, Danielle, Mariana, Lúcio. À Patrícia Santana, que sabe que sem ela não seríamos nada, e aos professores Suzuki, Carlos Pinto e Balbo.

Ao grupo Ecorodovias e à Ecopistas, pelo incentivo e apoio na construção do trecho experimental. Ao Adolfo, Everton e Wendell que estavam sempre prontos 
para nos atender em quaisquer esclarecimentos. À Dynatest, especialmente ao Felipe Camargo, à Usina PSI, à S\&P Reinforcements (Paulo Murgel e Filipe Dourado) e à Vale do Rio Novo, pela ajuda com o levantamento de dados necessários à pesquisa, fornecimento de materiais e execução do trecho experimental, respectivamente.

A todos que aqui não foram citados, mas também contribuíram de forma direta ou indireta para a conclusão deste trabalho, muito obrigada. 


\section{RESUMO}

A aplicação de pintura de ligação entre camadas asfálticas é prática comum em obras de pavimentos novos ou restaurações, sendo importante para garantir a aderência entre as camadas. Esse tratamento da interface geralmente é feito com emulsão asfáltica, que faz com que a estrutura do pavimento trabalhe como um sistema monolítico, evitando problemas de trincamento precoce por fadiga, ou escorregamentos. Esse trabalho tem como objetivo estudar a variabilidade de comportamento dos revestimentos asfálticos quanto à aderência na interface, tendo em vista a taxa aplicada de pintura de ligação, o tipo de emulsão (convencional ou modificada por polímero), a superfície de contato entre as camadas e a presença, ou não, de um sistema anti-reflexão de trincas (geotêxtil e grelha de fibra de vidro). A aderência foi medida por meio do ensaio de cisalhamento direto Leutner, em amostras produzidas em laboratório e extraídas de pista. Foram produzidas placas com dupla camada de revestimento asfáltico, sendo a camada superior um CBUQ (Concreto Betuminoso Usinado a Quente) e a inferior, ora SAMI (Stress Absorbing Membrane Interlayer), ora $\mathrm{CB \cup Q}$, variando a taxa de aplicação de pintura de ligação na interface $\left(0,0 ; 0,25 ; 0,5\right.$ e $\left.0,75 \mathrm{~L} / \mathrm{m}^{2}\right)$ e o tipo de emulsão aplicada (RR-1C, RR1C-E e RR-2C-E), além de testar duas diferentes dimensões para as amostras cilíndricas ensaiadas (100 e $150 \mathrm{~mm}$ de diâmetro). Os ensaios de cisalhamento direto foram feitos com carregamento monotônico, à taxa de deslocamento de $50 \mathrm{~mm} / \mathrm{min}$ e à temperatura de $20^{\circ} \mathrm{C}$. Realizou-se o mesmo ensaio também com velocidade de $1 \mathrm{~mm} / \mathrm{min}$ para avaliar a influência desse parâmetro nos resultados de aderência para as três emulsões testadas. As amostras de pista, com $100 \mathrm{~mm}$ de diâmetro, foram retiradas de um trecho experimental na Rodovia Ayrton Senna (SP070), do km 38,000 ao 39,500. Os resultados do teste de aderência em laboratório demonstraram influência do tipo de emulsão, da presença de geotêxtil/grelha na interface, do diâmetro da amostra, da textura superficial entre camadas e da velocidade de ensaio nos valores de tensão cisalhante máxima e na taxa ótima de aplicação de emulsão. Os valores de taxa ótima de pintura de ligação foram maiores quando na presença de geotêxtil na interface e para superfícies de contato com maior macrotextura. Quanto à aderência, as amostras com grelha não apresentaram diferença significativa comparadas ao uso de interface somente com pintura de ligação, enquanto as amostras com geotêxtil na interface resultaram em valores bem 
inferiores de tensão cisalhante máxima. Para ensaios com diferentes tipos de pintura de ligação, as amostras com emulsão modificada nem sempre apresentaram melhores resultados em relação às amostras com emulsão convencional.

Palavras chave: Aderência, Pintura de ligação, Emulsão Asfáltica, Geossintéticos, Ensaio de Cisalhamento Leutner. 


\begin{abstract}
Asphalt tack coat is commonly applied at the interface between asphalt layers during new pavement construction or overlay to ensure proper bond between the layers. This treatment at the interface, usually done with asphalt emulsion, allows the pavement structures to function as a monolithic system, avoiding problems like premature fatigue cracking, or slippage. This study aims to evaluate: (i) the influence of the tack coat type (neat or polymer modified asphalt emulsion), (ii) the application rate, (iii) the surface type, and (iv) the presence, or not, of an anti-reflective cracking interlayer (geotextile and fiber glass grid), in the adhesion properties between asphalt concrete layers. The adhesion between layers was tested through the Leutner shear test in laboratory and field samples. A double-layer system was produced with HMA as the top layer and SAMI (Stress Absorbing Membrane Interlayer), or HMA, as the bottom layer, varying the tack coat type (RR-1C, RR-1C-E e RR-2C-E), the application rate at the interface $\left(0,0 ; 0,25 ; 0,50\right.$ and $\left.0,75 \mathrm{~L} / \mathrm{m}^{2}\right)$ and the samples diameter (100 and $150 \mathrm{~mm}$ diameter). It was used the standard shear displacement rate of $50 \mathrm{~mm} / \mathrm{min}$, and the test temperature was set at $20^{\circ} \mathrm{C}$. The same procedure was run with a displacement rate of $1 \mathrm{~mm} / \mathrm{min}$ to evaluate its influence on the adhesion of three asphalt emulsions used as the tack coat. An experimental test section was constructed on Rodovia Ayrton Senna (SP-070), from km 38,000 to 39,500, and core samples (100 mm diameter) were extracted. The results of maximum shear stress demonstrate the influence of the tack coat type, the surface type, the sample diameter, the test displacement rate and the presence of a geotextile/grid on the adhesion at the interface between the asphalt layers,. Samples with grid at the interface presented similar results when compared with the samples with only tack coat at the interface. Samples with geotextile, however, presented significant lower values of maximum shear stress. The Leutner results showed that not always the modified asphalt emulsions present higher shear strength when compared to the neat asphalt emulsions.
\end{abstract}

Keywords: Interface Bond, Tack Coat, Emulsified Asphalt, Geoshyntetics, Leutner shear test. 


\section{LISTA DE ILUSTRAÇÕES}

Figura 2.1 - Tensões horizontal e vertical críticas para pavimentos asfálticos flexíveis .30

Figura 2.2 - Seção de pavimento analisada no software WESLEA .33

Figura 2.3 - Interface gráfica do software WESLEA para análise de aderência total ou nula

Figura 2.4 - Parâmetros de entrada para avaliar a interface entre camadas, adaptado de Romanoschi e Metcalf (2001b).

Figura 2.5 - Escorregamento de camada superficial asfáltica perceptível pela curvatura dos groovings. Pavimento do Newark International Airport, New Jersey, EUA (BOGNACKI et al., 2007)

Figura 2.6 - Trincamento por escorregamento entre camadas (MOHAMMAD et al., 2012)

Figura 2.7 - Bipolaridade do composto emulsificante 38

Figura 2.8 - Aplicação de emulsão asfáltica como pintura de ligação por meio de barra espargidora

Figura 2.9 - Aplicação de emulsão asfáltica como pintura de ligação por meio de caneta

Figura 2.10 - Ensaio de cisalhamento direto com aplicação de carga vertical normal (CHEN e HUANG, 2010)

Figura 2.11 - ASTRA (CANESTRARI et al., 2005; SANTAGATA et al., 2009). .52

Figura 2.12 - Leutner Shear Test (Laboratório de Tecnologia de Pavimentação Escola Politécnica da USP)

Figura 2.13 - LPDS (CANESTRARI et al., 2005; RAAB e PARTL, 2004; SANTAGATA et al., 2009) .52

Figura 2.14 - LISST (MOHAMMAD et al., 2012) 53

Figura 2.15 - FDST - Florida DoT Shear Tester (TASHMAN et al., 2006). 53

Figura 2.16 - UPOT - Utep Pull-off Test (TASHMAN et al., 2006) 
Figura 2.17 - Torque Bond Test (TASHMAN et al., 2006)

Figura 3.1 - (a) Visão geral da usina; (b) Material coletado para envio ao LTP/EPUSP

Figura 3.2 - Granulometria das misturas de CBUQ e SAMI 60

Figura 3.3 - Determinação do resíduo por evaporação 61

Figura 3.4 - Ensaio de resíduo por evaporação e viscosidade Brookfield (a) amostras na estufa para evaporação da água; (b) pesagem da massa de ligante residual para certificação da evaporação de toda a água (ensaio de resíduo); (c), (d), (e) e (f) preparação da amostra para o ensaio de viscosidade; (g) e (h) equipamento de ensaio (viscosidade Brookfield) .63

Figura 3.5 - Curvas de viscosidade versus temperatura para ensaio de viscosidade Brookfield nos resíduos das Emulsões 1 e 2 .

Figura 3.6 - Ensaio de recuperação elástica (a) alongamento das amostras; (b) amostras durante retorno elástico

Figura 3.7 - (a) Geotêxtil e (b) Grelha de fibra de vidro, ambos utilizados para confecção das amostras em laboratório. .65

Figura 3.8 - Sistema de dupla camada (SAMI+CBUQ) .65

Figura 3.9 - (a) e (b) Molde de $5 \mathrm{~cm}$ e utilização de placas de madeira $(2 \times 1,5 \mathrm{~cm})$ para compactação da (c) camada de SAMI $(e=2,0 \mathrm{~cm})$.

Figura 3.10 - Pesagem das misturas para compactação com espessuras de 2,0 cm (SAMI) e $5,0 \mathrm{~cm}(\mathrm{CBUQ})$

Figura 3.11 - Misturas em estufa para garantir temperatura de compactação $\left(140^{\circ} \mathrm{C}\right.$ a $\left.150^{\circ} \mathrm{C}\right)$

Figura 3.12 - Compactação da camada de SAMI (a) mesa compactadora LCPC; (b) colocação da mistura de SAMI (140ํㅡ); (c) e (d) compactação; (e) e (f) camadas de SAMl finalizadas. .68

Figura 3.13 - Aplicação de pintura de ligação na interface SAMI-CBUQ (a) controle da taxa de emulsão por pesagem sequencial do conjunto recipiente+pincel+emulsão 
antes e após aplicação; (b) aplicação de pintura de ligação com pincel; (c) e (d) emulsão após aplicação a espera da ruptura

Figura 3.14 - Preparo da interface das placas com reforço de geotêxtil: (a) e (b) recorte de retângulos da manta geotêxtil nas dimensões da placa $(18 \times 50 \mathrm{~cm})$; (c) e (d) manta de geotêxtil sobre a placa de SAMI antes da compactação da camada de CBUQ (placa P4, taxa de emulsão 0,0L/m²) .70

Figura 3.15 - Preparo da interface das placas com reforço de grelha de fibra de vidro (a) recorte de retângulos da grelha de fibra de vidro nas dimensões da placa $(18 \times 50 \mathrm{~cm})$ (b) grelha aplicada sobre a placa de SAMI antes da compactação da camada de CBUQ .70

Figura 3.16 - Aplicação de emulsão após colocação da manta geotêxtil .71

Figura 3.17 - Aplicação de grelha de fibra de vidro (a) queima do filme plástico protetor da grelha; (b) grelha a espera da compactação da camada de CBUQ.......71

Figura 3.18 - (a) Compactação da camada de CBUQ na mesa compactadora LCPC; (b) placa com dupla camada (SAMI+CBUQ) pronta .72

Figura 3.19 - Sistema de dupla camada (CBUQ+CBUQ) .72

Figura 3.20 - Textura das misturas de SAMI e CBUQ (a) placa de SAMI após compactação; (b) placa de CBUQ após compactação .73

Figura 3.21 - (a) Extração de corpos de prova cilíndricos (150 e 100 mm de diâmetro) nas placas somente com pintura de ligação na interface; (b) CPs extraídos, aguardando secagem .75

Figura 3.22 - (a) MTS e (b) aparato para realização do ensaio de cisalhamento Leutner. .75

Figura 3.23 - Corpos de prova antes do ensaio de cisalhamento (a) exemplo de CP (SAMI-CBUQ) com 150 mm de diâmetro e grelha na interface; (b) exemplo de CP (SAMI-CBUQ) com 100 mm de diâmetro e geotêxtil na interface; (c) CP (SAMICBUQ) só com pintura na interface; (d) CP (CBUQ-CBUQ) só com pintura na interface 76

Figura 3.24 - Preparação dos corpos de prova no equipamento Leutner (a) amostra com 150mm; (b) amostra com 100mm. 
Figura 4.1 - Corpos de prova após ruptura por cisalhamento: (a) SAMI-CBUQ somente com pintura de ligação na interface; (b) SAMI-CBUQ com geotêxtil+pintura na interface; (c) SAMI-CBUQ com grelha+pintura na interface; (d) $C B \cup Q+C B \cup Q$ somente com pintura de ligação na interface .78

Figura 4.2 - Corpos de prova que romperam na mistura. 78

Figura 4.3 - Broqueamento feito de forma desnivelada dificultando a definição da interface entre camadas 79

Figura 4.4 - Tensão cisalhante máxima versus taxa de aplicação da pintura de ligação - amostras de $150 \mathrm{~mm}$ de diâmetro só com pintura de ligação na interface 81 Figura 4.5 - Tensão de cisalhante máxima versus taxa de aplicação da pintura de ligação - comparativo entre Emulsão 1, 2 e 3

Figura 4.6 - Tensão cisalhante máxima para diferentes velocidades de ensaio (CP $150 \mathrm{~mm})$

Figura 4.7 - Tensão cisalhante máxima para diferentes tamanhos de amostra (Emulsão 1) .85

Figura 4.8 - Tensão cisalhante máxima para diferentes tamanhos de amostra (Emulsão 2) .86

Figura 4.9 - Tensão cisalhante máxima para diferentes tamanhos de amostra (Emulsão 3) .86

Figura 4.10 - (a) Posição original do broqueamento das amostras com pintura de ligação na interface e (b) novo posicionamento testado (Emulsão 1 a $0,25 \mathrm{~L} / \mathrm{m}^{2}$ ) ....87 Figura 4.11 - Tensão cisalhante máxima para diferentes posicionamentos de extração das amostras cilíndricas .87

Figura 4.12 - Comportamento da curva de tensão cisalhante máxima versus deslocamento para amostras de 100 e 150 mm de diâmetro .88

Figura 4.13 - Tensão cisalhante versus taxa de aplicação da pintura de ligação Amostras de $150 \mathrm{~mm}$ de diâmetro, com pintura e geotêxtil na interface 89 
Figura 4.14 - Tensão cisalhante versus taxa de aplicação da pintura de ligação Amostras de $150 \mathrm{~mm}$ de diâmetro, com pintura e grelha na interface

Figura 4.15 - Corpos de prova com pintura+grelha onde (a) a ruptura ocorreu em direção diagonal à malha da grelha; e (b) a ruptura ocorreu na mesma direção da grelha. (c) Direção de ruptura controlada para ensaios refeitos para Emulsão 1 .......91

Figura 4.16 - Tensão cisalhante versus taxa de aplicação da pintura de ligação Amostras de $150 \mathrm{~mm}$ de diâmetro, com pintura e grelha na interface 92

Figura 4.17 - Tensão cisalhante versus taxa de aplicação da pintura de ligação Amostras de $150 \mathrm{~mm}$ de diâmetro, com pintura e grelha na interface .93

Figura 4.18 - Tensão cisalhante versus taxa de aplicação da pintura de ligação para diferentes texturas superficiais entre camadas (CP $150 \mathrm{~mm}$ )

Figura 4.19 - Tensão cisalhante versus taxa de aplicação da pintura de ligação para diferentes texturas superficiais entre camadas (CP $100 \mathrm{~mm}$ ) .95

Figura 4.20 - (a) Gráficos de tensão cisalhante máxima versus deslocamento e (b) módulo de reação na interface para amostras Emulsão 1, 2 e 3 (CP 150 mm).

Figura 4.21 - (a) Gráficos de tensão cisalhante máxima versus deslocamento e (b) módulo de reação na interface para diferentes velocidades de ensaio

Figura 4.22 - (a) Gráficos de tensão cisalhante máxima versus deslocamento e (b) módulo de reação na interface para amostras com diferentes texturas superficiais (CP $150 \mathrm{~mm}$ ) 99

Figura 4.23 - (a) Gráficos de tensão cisalhante máxima versus deslocamento e (b) módulo de reação na interface para amostras com presença ou não de geotêxtil/grelha (CP $150 \mathrm{~mm}$ ) 100

Figura 4.24 - Módulo de reação na interface para amostras com 150 e 100 mm de diâmetro 101 
Figura 5.1 - Mapa de localização do trecho experimental. Adaptado de www.maps.google.com

Figura 5.2 - Levantamento deflectométrico FWD com carga de 4,1 t (abril de 2010) 104

Figura 5.3 - Levantamento de defeitos no pavimento do trecho experimental

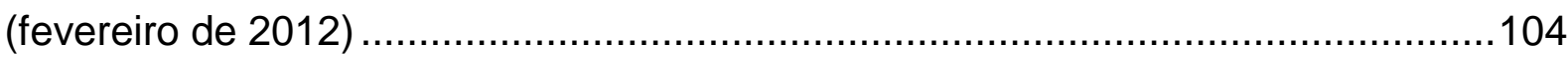

Figura 5.4 - Execução de poço de inspeção de pavimento ………........................105

Figura 5.5 - Camadas do pavimento existente (Poço de inspeção km 38, fornecido pela concessionária Ecopistas) ......................................................................105

Figura 5.6 - Distância entre a Usina PSI e o Trecho Experimental. Adaptado de www.maps.google.com .........................................................................107

Figura 5.7 - Esquema com as seções-teste do trecho experimental......................108

Figura 5.8 - Levantamento FWD antes do início da obra ....................................109

Figura 5. 9 - Levantamento FWD e LWD na caixa fresada ...................................109

Figura 5. 10 - Fresagem de $6,0 \mathrm{~cm}$ da camada asfáltica antiga ............................109

Figura 5. 11 - Limpeza com ar comprimido da superfície após fresagem ................109

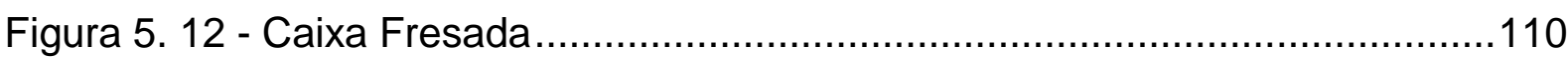

Figura 5. 13 - Fissuras na estrutura remanescente ...........................................110

Figura 5. 14 - Pintura de ligação aplicada sobre a superfície fresada (1) ..............110

Figura 5. 15 - Pintura de ligação aplicada sobre a superfície fresada (2) …...........110

Figura 5. 16 - Execução da camada de SAMI nos trechos T1 e T2 ......................110

Figura 5. 17 - Compactação da camada de SAMI com rolo liso...............................110

Figura 5. 18 - Camada de SAMI pronta........................................................111

Figura 5. 19 - Textura final da superfície da camada de SAMI..............................111

Figura 5. 20 - Aplicação da pintura de ligação sobre as camadas de SAMI, nos trechos T1 e T2, e sobre a camada asfáltica fresada no trecho T3........................111

Figura 5. 21 - Pintura de ligação aplicada ……………...................................111 
Figura 5. 22 - Aplicação do geotêxtil nos trechos T2 e T3

Figura 5. 23 - Fixação do geotêxtil com prego

Figura 5. 24 - Geotêxtil aplicado nos trechos T2 e T3 (1) ......................................112

Figura 5. 25 - Geotêxtil aplicado nos trechos T2 e T3 (2) .....................................112

Figura 5. 26 - Pintura de ligação aplicada com caneta sobre o geotêxtil ................112

Figura 5. 27 - Manta geotêxtil grudando no pneu do caminhão ………………....112

Figura 5. 28 - Aplicação de óleo mineral para evitar que o pneu do caminhão basculante arranque o geotêxtil ......................................................................112

Figura 5. 29 - Aplicação de óleo mineral no rolo de pneu ......................................112

Figura 5. 30 - Execução da camada de CBUQ em todos os trechos .....................113

Figura 5. 31 - Compactação com rolos de pneu e liso .........................................113

Figura 5. 32 - Fresagem de $6,0 \mathrm{~cm}$ da camada asfáltica antiga (1) .....................113

Figura 5. 33 - Fresagem da camada asfáltica antiga (2) ...................................113

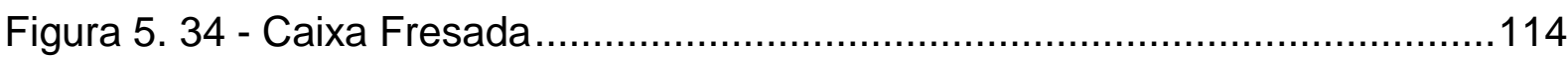

Figura 5. 35 - Trincamento acentuado na caixa remanescente $(\mathrm{km} \mathrm{38,174)}$..........114

Figura 5. 36 - Aplicação de pintura de ligação nas bordas da caixa fresada com

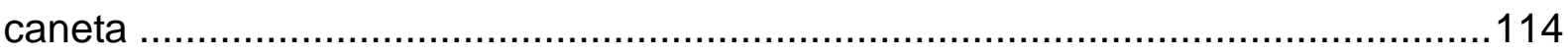

Figura 5. 37 - Superfície fresada com pintura de ligação aplicada por caminhão

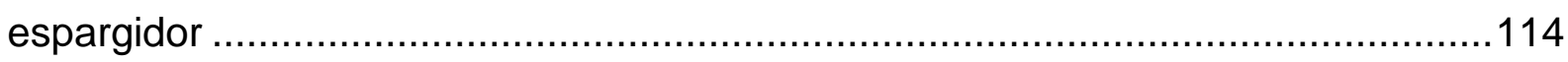

Figura 5.38 - Execução da camada de SAMI do trecho T4 …..............................114

Figura 5.39 - Textura final da superfície da camada de SAMI no trecho T4 ….......114

Figura 5.40 - Aplicação de pintura de ligação com caneta sobre a camada de SAMI

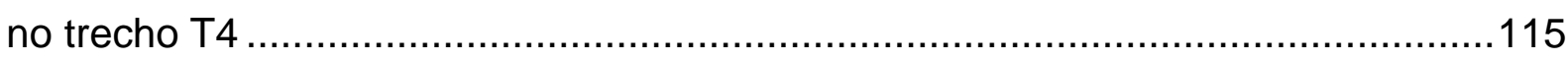

Figura 5.41 - Aplicação da grelha de fibra de vidro (1) .........................................115

Figura 5.42 - Aplicação da grelha de fibra de vidro (2)......................................115

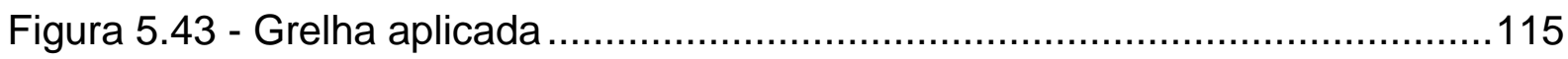

Figura 5.44 - Queima do filme plástico remanescente na grelha ..........................115 
Figura 5.45 - Textura final da superfície com grelha

Figura 5.46 - Aplicação de segunda faixa de grelha

Figura 5.47 - Pintura de ligação na superfície fresada dos trechos T5 e T6

Figura 5.48 - Aplicação de óleo mineral para evitar que o pneu do caminhão basculante arranque a grelha 116

Figura 5.49 - Pintura de ligação com polímero aderindo ao pneu do caminhão......116

Figura 5.50 - Aplicação da camada de CBUQ..................................................116

Figura 5.51 - Compactação da camada de CBUQ …………………………....116

Figura 5.52 - Controle de temperatura na vibroacabadora.................................117

Figura 5.53 - Controle de temperatura em pista após lançamento da mistura ........117

Figura 5.54 - Medidas da taxa de aplicação da pintura de ligação em campo ........119

Figura 5.55 - Pintura de ligação aplicada, (a) antes e (b) depois da ruptura ...........120

Figura 5. 56 - Levantamento Merlin após a obra.................................................120

Figura 5.57 - Resultados do monitoramento com FWD …………......................122

Figura 5.58 - Bacia de deflexão média do levantamento FWD para o trecho T1 (CBUQ+SAMI com pintura de ligação na interface) ............................................123

Figura 5.59 - Bacia de deflexão média do levantamento FWD para o trecho T2 (CBUQ+SAMI com geotêxtil na interface) .....................................................124

Figura 5.60 - Bacia de deflexão média do levantamento FWD para o trecho T3 (CBUQ sobre superfície fresada com geotêxtil na interface)

Figura 5.61 - Bacia de deflexão média do levantamento FWD para o trecho T4 (CBUQ+SAMI com grelha na interface) 125

Figura 5.62 - Bacia de deflexão média do levantamento FWD para o trecho T5 (CBUQ sobre superfície fresada com grelha na interface) 125

Figura 5.63 - Bacia de deflexão média do levantamento FWD para o trecho T6 (CBUQ sobre superfície fresada com pintura de ligação na interface). 126

Figura 5.64 - Extração dos corpos de prova cilíndricos para ensaio de cisalhamento (abril de 2012). 
Figura 5.65 - Extração dos corpos de prova cilíndricos para ensaio de cisalhamento (julho de 2012)

Figura 5.66 - MTS e aparato para realização do ensaio de cisalhamento Leutner.129

Figura 5.67 - CP antes de romper - Trecho T4 - Bordo direito da pista. 129

Figura 5.68 - CP antes de romper - Trecho T4 - Eixo da pista 129

Figura 5.69 - Ruptura por cisalhamento - Trecho T4 (SAMI+Grelha) 130

Figura 5.70 - Ruptura por cisalhamento - Trecho T4 - Eixo da pista 130

Figura 5.71 - Ruptura por cisalhamento - Trecho T2 (SAMI+Geotêxtil) 130

Figura 5.72 - Ilustração da pintura de ligação no geotêxtil de CP já rompido 130

Figura 5.73 - Corpos de prova com geotêxtil rompidos (a) durante a extração em campo e (b) o transporte do campo ao laboratório. 131

Figura 5.74 - Plano irregular de interface entre camadas 131 


\section{LISTA DE TABELAS}

Tabela 2.1 - Resultados de tensão e deformação na fibra inferior da camada asfáltica nova para total aderência e total escorregamento 34

Tabela 2.2 - Valores de correção da taxa de aplicação em função das condições superficiais do pavimento existente (DER-SP, 2006)

Tabela 2.3 - Valores recomendados pelo DER-PR para taxa de pintura de ligação (DER-PR, 2005)

Tabela 3.1 - Matriz da programação de ensaios de cisalhamento com quantidade de amostras moldadas em laboratório 58

Tabela 3.2 - Caracterização do ligante asfáltico utilizado nas misturas 60

Tabela 3.3 - Resultado do ensaio de resíduo por evaporação 61

Tabela 3.4 - Propriedades principais do geotêxtil utilizado no trecho experimental ..64 Tabela 3.5 - Propriedades principais da grelha de fibra de vidro utilizada no trecho experimental. .65

Tabela 3.6 - Macrotextura das superfícies de SAMI e CBUQ, por meio do ensaio de mancha de areia.

Tabela 4.1 - Taxa real de aplicação de pintura de ligação nas placas moldadas em laboratório 80

Tabela 5.1 - Taxas de aplicação da pintura de ligação em campo. 118

Tabela 5.2 - Resumo dos resultados do ensaio de cisalhamento Leutner 132 


\section{LISTA DE ABREVIATURAS E SIGLAS}

ABNT

ASTM

ASTRA

BGTC

BGS

CAP

CAR

CBUQ

CHEV

$\mathrm{CP} / \mathrm{CPs}$

CPA

DNIT

DER-SP

DER-PR

EPUSP

FDST

FWD

LCPC

LISST

LPDS

LROP

LTP

LVDT

LWD

MEF

MTS

NBR

NCAT

PDMAP

PMF

PSI

SAMI
Associação Brasileira de Normas Técnicas

American Society for Testing and Materials

Ancona Shear Testing Research and Analysis

Brita Graduada Tratada com Cimento

Brita Graduada Simples

Cimento Asfáltico de Petróleo

Camada asfáltica remanescente

Concreto Betuminoso Usinado a Quente

Chevron Elastic Layer Analysis Program

Corpo de Prova / Corpos de Prova

Camada Porosa de Atrito

Departamento Nacional de Infra-Estrutura de Transportes

Departamento Estradas de Rodagem de São Paulo

Departamento Estradas de Rodagem do Paraná

Escola Politécnica da USP

Florida Dot Shear Tester

Falling Weight Deflectometer

Laboratoire Central dês Ponts et Chaussées

Louisiana Interlayer Shear Strength Tester

Layer-Parallel Direct Shear Device

Laboratoire Régional de l'Ouest Parisien

Laboratório de Tecnologia de Pavimentos

Linear Variable Differential Transducer

Light Weight Deflectometer

Método dos Elementos Finitos

Material Test System

Norma Brasileira Regulamentadora

National Center for Asphalt Technology

Probabilistic Distress Models for Asphalt Pavements

Pré-Misturado a Frio

Pedreira e Pavimentadora Santa Isabel

Stress Absorbing Membrane Interlayer 
UPOT Utep Pull off Test

WESLEA Waterways Engineering Station Elastic Layer Analysis Pavement Suite 


\section{LISTA DE SÍMBOLOS}

$\begin{array}{ll}K^{\prime} & \text { Módulo de reação ao cisalhamento horizontal } \\ \mu & \text { Atrito Superficial } \\ Q_{D} & \text { Quantidade de ligante de projeto } \\ Q_{S} & \begin{array}{l}\text { Índice de saturação do geotêxtil a ser utilizado } \\ Q_{C}\end{array} \quad \begin{array}{l}\text { Correção baseada na demanda necessária pela superfície do } \\ \text { pavimento existente }\end{array} \\ H_{M} & \text { Altura média de mancha de areia } \\ V & \text { Volume constante de areia de } 25.000 \mathrm{~mm}^{3} \\ D_{M} & \text { Diâmetro médio do círculo de areia } \\ \bar{X} & \text { Média dos valores encontrados nos ensaios } \\ S & \text { Desvio padrão dos valores } \\ F & \text { Força } \\ \text { A } & \text { Área } \\ \delta & \text { Tensão cisalhante } \\ \sigma_{H} & \text { Tensão de tração } \\ \sigma_{V} & \text { Tensão de compressão }\end{array}$




\section{SUMÁRIO}

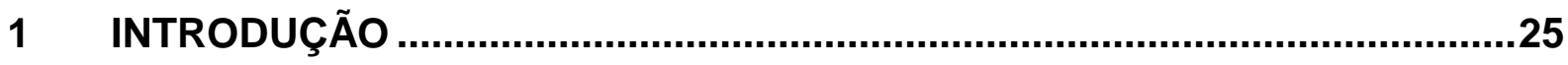

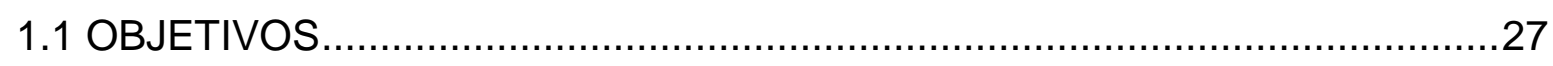

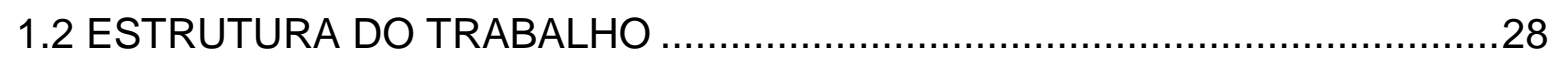

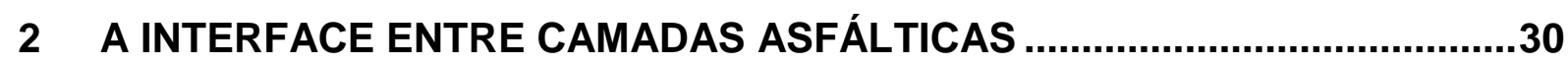

2.1 TENSÕES E COMPORTAMENTO NA INTERFACE....................................30

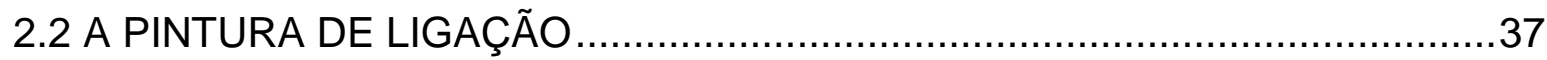

2.3 SISTEMAS ANTI-REFLEXÃO DE TRINCAS - GEOTÊXTEIS E GRELHAS ...43

2.4 SUPERFÍCIE DE CONTATO E O INTERTRAVAMENTO ENTRE AS

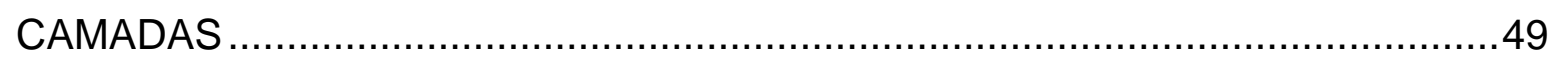

2.5 MEDIDAS DE ADERÊNCIA ENTRE CAMADAS ..........................................50

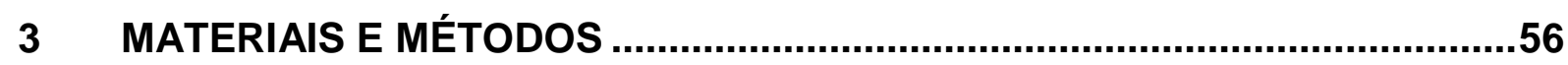

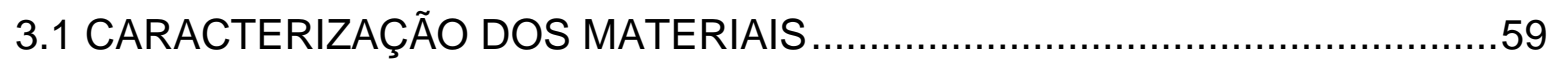

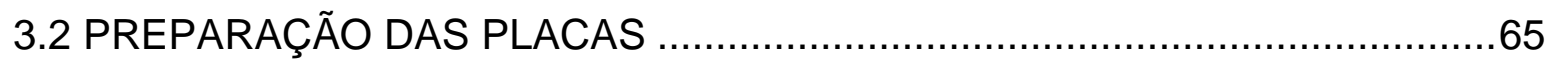

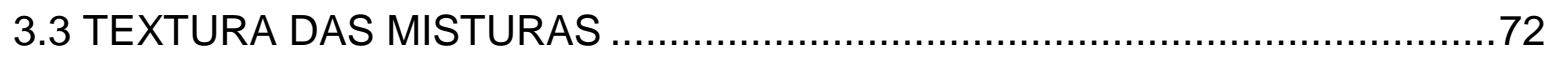

3.4 ENSAIO LEUTNER PARA MEDIDA DA ADERÊNCIA ENTRE CAMADAS ....74

4 APRESENTAÇÃO E DISCUSSÃO DOS RESULTADOS ……….....................77

4.1 EFEITO DA TAXA DE APLICAÇÃO E DO TIPO DE PINTURA DE LIGAÇÃO81 4.2 EFEITO DA VELOCIDADE DE ENSAIO PARA OS DIFERENTES TIPOS DE

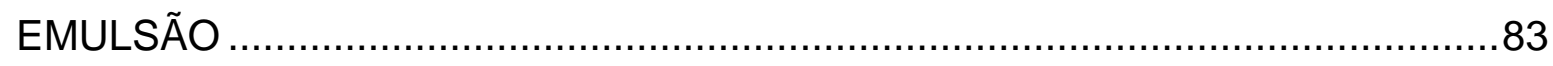

4.3 EFEITO DO TAMANHO DA AMOSTRA NO ENSAIO DE CISALHAMENTO

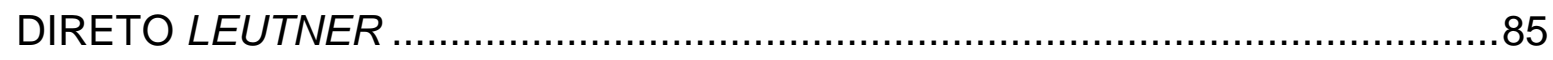

4.4 EFEITO DO USO DE SISTEMAS ANTI-REFLEXÃO DE TRINCAS NA

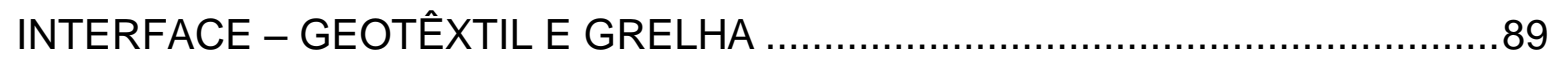

4.5 EFEITO DA TEXTURA SUPERFICIAL DAS CAMADAS ..............................94

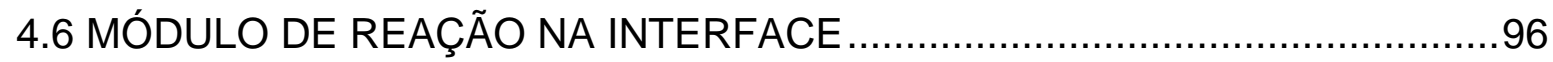

5 TRECHO EXPERIMENTAL …......................................................................102

5.1 CARACTERIZAÇÃO DO TRECHO EXPERIMENTAL ................................103 
5.2 SOLUÇÕES DE RESTAURAÇÃO PARA O TRECHO EXPERIMENTAL......105

5.3 EXECUÇÃO DO TRECHO EXPERIMENTAL ...........................................108

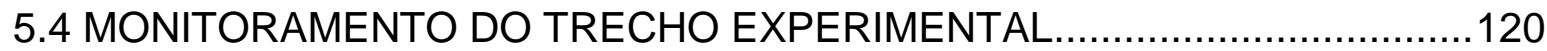

6 CONSIDERAÇÕES FINAIS ..................................................................134

REFERÊNCIAS BIBLIOGRÁFICAS .............................................................137

ANEXOS - ESPECIFICAÇÃO DE MATERIAIS ................................................144

A. Emulsão asfáltica catiônica convencional de ruptura rápida (E1 : RR-1C) ......145

B. Emulsão asfáltica catiônica de ruptura rápida modificada por polímero (E2 : RR-

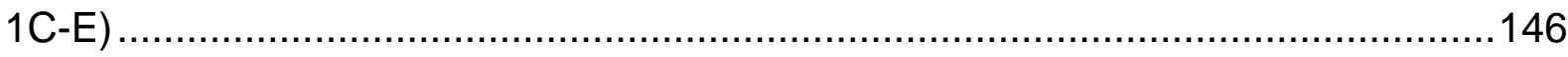

C. Emulsão asfáltica catiônica de ruptura rápida modificada por polímero (E3: RR-

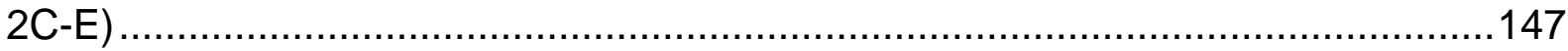

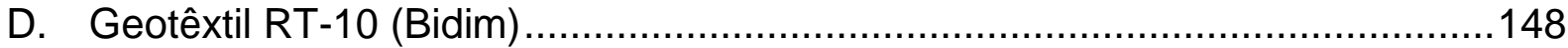

E. Grelha de fibra de vidro (S\&P Reinforcement) .....................................149

F. Ligante utilizado nas misturas de CBUQ .............................................. 150

G. Caracterização das misturas de CBUQ ...........................................151

$\mathrm{H}$. Ligante utilizado nas misturas de SAMI ............................................. 184

I. Caracterização das misturas de SAMI ................................................... 185 


\section{INTRODUÇÃO}

Os pavimentos asfálticos deterioram-se com o tempo pelo efeito combinado do tráfego e do clima. A degradação do pavimento e, principalmente do revestimento asfáltico, além de reduzir a rigidez da camada, aumentando, portanto, as deflexões, muitas vezes permite a entrada de água por meio de trincas, fazendo com que a estrutura fique cada vez mais susceptível à desagregação. $O$ decréscimo da condição de serventia do pavimento ao longo do tempo ainda é caracterizado pela evolução das deformações nas trilhas de roda e da irregularidade longitudinal, impactando no conforto e na segurança dos usuários.

Para melhorar as condições de trafegabilidade, antes que haja comprometimento da vida útil dos pavimentos, as rodovias devem passar constantemente por processos de recuperação, que muitas vezes são feitos por meio de recapeamento com nova camada de revestimento asfáltico. Entre a nova camada e a antiga deve-se aplicar uma pintura de ligação, de modo que a camada nova a ser executada esteja completamente aderida à superfície antiga (DNIT ES395/99; DNIT ES-145/2010; DNIT, 2006; DER-SP, 2005; DER-PR, 2005). A mesma recomendação é feita para a execução de duas camadas asfálticas em um pavimento novo.

A pintura de ligação é a aplicação de uma película delgada de ligante asfáltico, geralmente uma emulsão asfáltica, entre camadas de pavimento (BERNUCCl et al., 2008). A principal função da pintura de ligação é promover perfeita aderência na interface das camadas e garantir um deslocamento contínuo entre elas, fazendo com que o pavimento funcione como uma estrutura monolítica, tal qual foi projetado (MOHAMMAD et al., 2002; TASHMAN et al., 2006; DIAKHATE, 2005; CHEN e HUANG, 2010). Etapa simples e com custo relativamente baixo quando comparado ao valor total da execução de uma obra de pavimentação asfáltica, a pintura de ligação é essencial para o funcionamento adequado e o prolongamento da vida útil de pavimentos novos ou restaurações. 
Quando a aplicação da pintura de ligação ocorre em quantidade insuficiente para garantir boa aderência entre as duas camadas asfálticas, surgem tensões de tração de elevada magnitude na fibra inferior da camada superficial (SHAHIN et al., 1986). Este efeito, muito severo, produz geralmente um trincamento precoce por fadiga do revestimento novo (MUENCH et al., 2008; CHEN e HUANG, 2010). Por outro lado, o excesso de pintura, além de antieconômico, pode causar um escorregamento entre as camadas, representando também um problema para a estrutura do pavimento (ROMANOSCHI e METCALF, 2001a; ZIARI e KHABIRI, 2007; MUENCH et al., 2008; CHEN e HUANG, 2010). Neste caso, a camada asfáltica superior, por trabalhar não aderida, também estará sujeita a tensões de tração na fibra inferior maiores que o esperado e, portanto, ao trincamento precoce por fadiga.

Amostras com dupla camada de misturas asfálticas e pintura de ligação na interface, com diferentes taxas de aplicação de emulsão, sujeitas a ensaios de resistência ao cisalhamento direto, vêm sendo estudadas em outros países desde a década de 1970 (UZAN et al., 1978; PAUL e SHEROCMAN, 1998; MOHAMMAD et al., 2002; CHEN e HUANG, 2010). Esses estudos indicam a existência de uma taxa ótima de pintura de ligação que permita uma interface aderida e sem escorregamentos.

Em todos os estudos, o pico de resistência ao cisalhamento direto obtido nos ensaios é diretamente relacionado à aderência existente no contato entre camadas. Os resultados, porém, são conflitantes devido à grande variedade de fatores que influenciam nesta aderência. Segundo Tashman (2008), Sholar (2004), Cenestrari et al. (2005), Chen e Huang (2010), podem ser citados: o tipo de pintura de ligação, a taxa de aplicação residual, o tempo e a temperatura de cura, e as condições superficiais das camadas, devido ao intertravamento mecânico existente. Problemas de aderência também podem ocorrer quando não se atinge grau necessário de compactação, seja pela energia de compactação insuficiente, execução de camadas muito espessas, baixa temperatura de aplicação e chuva durante a execução da obra (RAAB e PARTL, 2004). A boa compactação da camada superior garante maior resistência ao cisalhamento na interface, o que configura melhor aderência entre camadas (CHEN e HUANG, 2010). 
Em locais com alto grau de trincamento, é comum a utilização de soluções de recapeamento com sistemas anti-reflexão de trincas aplicados na interface. São vários os materiais disponíveis no mercado: geotêxteis e geogrelhas (produzidos com material polimérico), grelhas com fibras de vidro ou fibras de carbono, telas de aço, dentre outros. Esses materiais são aplicados com a função de reduzir as tensões geradas nas camadas superiores e controlar o fenômeno de reflexão de trincas (MONTESTRUQUE, 2002; FIORIN, 2009). Porém, relatos de problemas de escorregamento e, portanto, não aderência entre as camadas, neste tipo de solução são frequentes. O geossintético ou a grelha na interface podem configurar um ponto de fragilidade, porque as fibras que constituem o material impedem o contato pleno entre as camadas (RAAB e PARTL, 2004). A presença desses materiais pode também influenciar no valor da taxa ótima da pintura de ligação em comparação com o sistema somente com a pintura de ligação.

Sendo a aderência entre camadas um fator essencial para o desempenho e a vida de serviço do pavimento, a sua análise é importante para compreender que as estruturas de pavimentos multicamadas nem sempre se comportam como sistemas monolíticos. $\mathrm{O}$ estudo da aderência entre camadas se faz necessário à medida que pode promover um aumento no intervalo entre intervenções, além de uma maior segurança e economia aos usuários.

\subsection{OBJETIVOS}

O trabalho objetiva estudar a variabilidade na aderência entre camadas asfálticas, avaliando a taxa de aplicação da pintura de ligação, o tipo de emulsão (convencional ou modificada por polímero) e a presença ou não de sistemas antireflexão de trincas na interface. Serão analisadas, por meio de ensaios de cisalhamento direto, amostras confeccionadas em laboratório e amostras extraídas de campo. As amostras de campo foram extraídas de um trecho experimental executado na rodovia Ayrton Senna, em São Paulo ( $k m$ 38,000 ao km 39+500, pista leste, sentido São Paulo - Guararema). 
Entre os objetivos específicos encontram-se:

- Comparativo de aderência para pintura de ligação executada com emulsão convencional e emulsão modificada por polímero;

- Comparativo de aderência para diferentes taxas de aplicação da pintura de ligação;

- Estudo da influência dos materiais de reforço anti-reflexão de trincas (geotêxtil e grelha) na aderência, variando tipos e taxas de pintura de ligação;

- Verificação da influência do tamanho da amostra nos resultados de aderência entre camadas medidos através do ensaio de cisalhamento direto Leutner;

- Estudo da influência da textura superficial das camadas na interface de contato e, portanto, na aderência entre elas.

\subsection{ESTRUTURA DO TRABALHO}

Esse documento está organizado em 6 capítulos descritos a seguir:

- O Capítulo 1 traz uma introdução ao tema de interesse da pesquisa, a fim de facilitar o entendimento e transmitir ao leitor uma ideia global da importância do estudo da aderência entre camadas asfálticas. Apresenta ainda os objetivos e a estrutura do trabalho.

- O Capítulo 2 apresenta a revisão bibliográfica, abordando aspectos e temas relevantes ao estudo da aderência entre revestimentos asfálticos. Esse capítulo engloba os estudos e pesquisas, nacionais e internacionais, em desenvolvimento sobre o assunto.

- O Capítulo 3 traz o desenvolvimento da pesquisa em laboratório, a metodologia do programa experimental, a caracterização dos materiais utilizados, e a descrição dos ensaios de cisalhamento direto realizados.

- O Capítulo 4 apresenta e discute os resultados obtidos para amostras produzidas em laboratório. 
- O Capítulo 5 descreve o trecho experimental realizado durante a pesquisa: suas características, metodologia de execução da obra, controles tecnológicos e ensaios executados com as amostras extraídas de pista.

- O Capítulo 6 traz as considerações finais e proposta para trabalhos futuros. 


\section{A INTERFACE ENTRE CAMADAS ASFÁLTICAS}

\subsection{TENSÕES E COMPORTAMENTO NA INTERFACE}

Os pavimentos são estruturas constituídas por um sistema de camadas sobrepostas, com espessuras finitas, sobre uma fundação de espessura infinita. $O$ pavimento é responsável por resistir aos esforços horizontais e distribuir ao subleito os esforços verticais que são produzidos pelo tráfego e por variações climáticas, melhorando as condições de rolamento e a segurança dos usuários (Figura 2.1). 0 dimensionamento desta estrutura para tráfego pesado geralmente é feito através de uma avaliação mecanicista das tensões e das deformações em cada camada, e posterior previsão de desempenho ao longo do tempo por meio de modelos apresentados na literatura. Os parâmetros de entrada para caracterização dos materiais que comporão a estrutura são comumente estimados ou obtidos por meio de ensaios realizados em laboratório. Os modelos empíricos de desempenho, no caso de pavimentos flexíveis, consideram critérios de fadiga e deformação plástica do subleito, prevendo o número de solicitações de carga que a estrutura resistirá (BALBO, 2007).

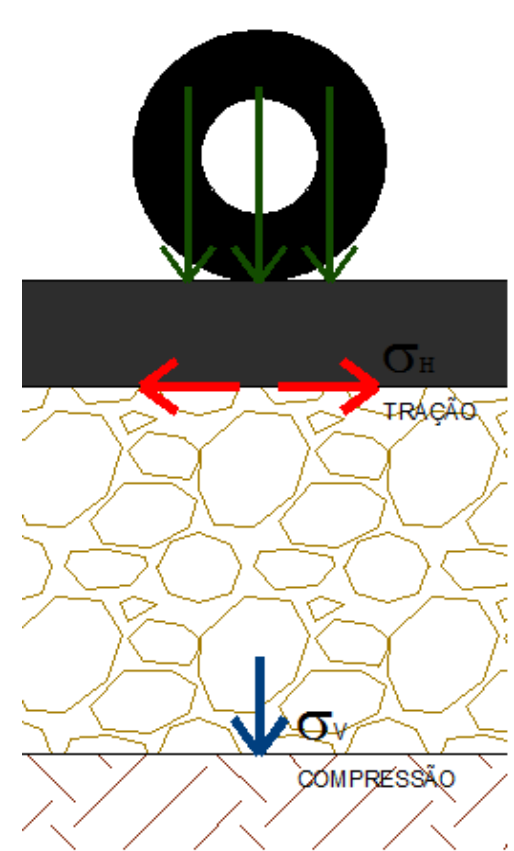

Figura 2.1 - Tensões horizontal e vertical críticas para pavimentos asfálticos flexíveis 
Os estudos para o cálculo das tensões e deformações nas camadas do pavimento iniciaram-se com a utilização da teoria da elasticidade por Boussinesq, em um sistema de única camada homogênea e isotrópica de espessura infinita. Desenvolvendo analiticamente as equações de Boussinesq, Burmister aplicou a teoria para sistemas de duas camadas, em 1943, e três camadas, em 1945 (HUANG, 1993). Posteriormente, a teoria elástico-linear foi estendida para sistemas multicamadas, com o desenvolvimento de softwares específicos, dentre os quais alguns podem ser citados (HUANG, 1993; BALBO, 2007):

- CHEV (Chevron Elastic Layer Analysis Program): Desenvolvido pela Chevron Research Company;

- WESLEA (Waterways Engineering Station Elastic Layer Analysis Pavement Suite): Desenvolvido pelo professor David H. Timm da Universidade de Alburn, Alabama;

- DAMA: Desenvolvido pelo Asphalt Institute;

- BISAR: Desenvolvido pela Shell;

- ELSYM5: Desenvolvido pela Universidade da Califórnia, Berkeley, para dimensionamento de pavimentos com até cinco camadas elásticas submetidas a cargas múltiplas;

- PDMAP (Probabilistic Distress Models for Asphalt Pavements) para previsão de desempenho de fadiga e deformação permanente.

As respostas estruturais das camadas do pavimento, baseadas na teoria elástico-linear de Boussinesq e Burmister, preconizam as seguintes hipóteses (HUANG, 1993; BALBO, 2007): i) todas as camadas são homogêneas, isotrópicas e possuem comportamento elástico linear ao longo da sua espessura; ii) o carregamento é uniforme e distribuído sobre carga circular; iii) existe perfeita aderência entre as camadas garantindo que o sistema funcionará monoliticamente.

No dimensionamento de pavimentos asfálticos considera-se, portanto, que as camadas tenham propriedades elásticas constantes (módulo de elasticidade e coeficiente de Poisson), carregamento distribuído uniformemente e, ainda, uma interface entre camadas completamente aderida. 
A total aderência na interface, porém, é algo que nem sempre ocorre em campo. Em laboratório, Mohammad et al. (2002) fizeram ensaios de cisalhamento entre camadas para corpos de prova monolíticos comparando os resultados em amostras de dupla camada com diferentes taxas e tipos de pintura de ligação na interface. Os melhores resultados das amostras de dupla camada chegaram a apenas $83 \%$ da resistência dos CPs monolíticos (sem interface). A construção de pavimentos em multicamadas garante melhorias no grau de compactação das misturas, mas, por outro lado, cria zonas de fragilidade na estrutura.

Os projetos de pavimentos, sejam de seções novas ou de recapeamentos, não levam em conta a possibilidade de falha na aderência entre camadas (RAAB e PARTL, 2004), e a maioria dos softwares de dimensionamento estrutural de pavimentos não contempla esse aspecto. Poucos, dentre os softwares mais utilizados, quando permitem considerar a aderência na interface, fazem-no por meio de um fator de atrito/escorregamento que pode assumir valor 0 (zero) ou 1 (um) (ZIARI e KHABIRI, 2007). Para o software WESLEA 3.0 (VAN CAUWELAERT et al, 1989; MUENCH e MOOMAW, 2008), por exemplo, o fator igual a 0 indica escorregamento e o fator igual a 1 completa aderência entre as camadas.

Estudos mostram que a falta de aderência entre camadas, seja ela causada pelo excesso ou pela falta de pintura de ligação na interface, provoca aumento de tensões na fibra inferior da camada mais superficial do revestimento (SHAHIN et al., 1986; Uzan et al., 1978). Ziari e Khabiri (2007) modelaram, por meio do software KENLAYER, uma estrutura de pavimento composta por camada asfáltica superficial, camada asfáltica intermediária (binder) e base granular. Os autores avaliaram a distribuição de tensões de tração ao longo das camadas do pavimento, com diferentes condições de interface entre as três camadas, considerando 1 (um) para contato total e 0 (zero) para total escorregamento. Nos casos de falta de aderência entre as duas camadas asfálticas (fator 0 ), as tensões horizontais de tração aumentaram de valor significativamente e surgiram como máximas na fibra inferior da camada superficial, a qual, em condições de total aderência, apresentou-se sob tensões verticais de compressão. As tensões verticais de compressão no topo do subleito também aumentaram para falta de aderência em todos os casos estudados. 
Com objetivo de melhor ilustrar o comportamento do pavimento e a distribuição de tensões ao longo da estrutura, utilizou-se o software WESLEA para analisar o sistema multi-camadas apresentado na Figura 2.2. O software permite a inserção de um fator 0 ou 1 para análise de total escorregamento ou total aderência, respectivamente, entre as camadas (Figura 2.3).

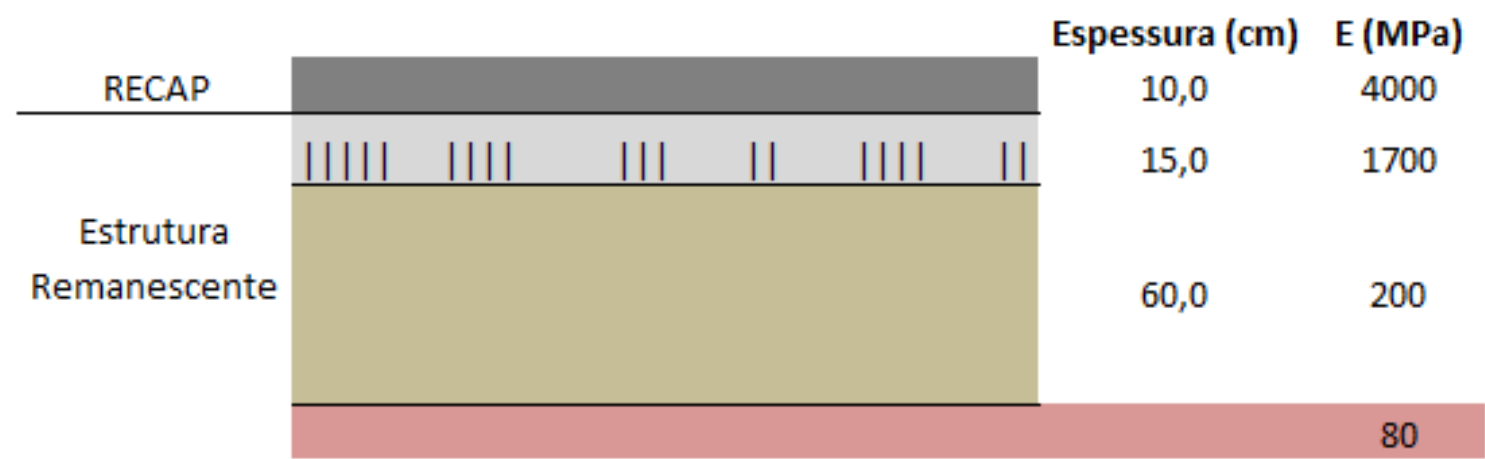

Figura 2.2 - Seção de pavimento analisada no software WESLEA

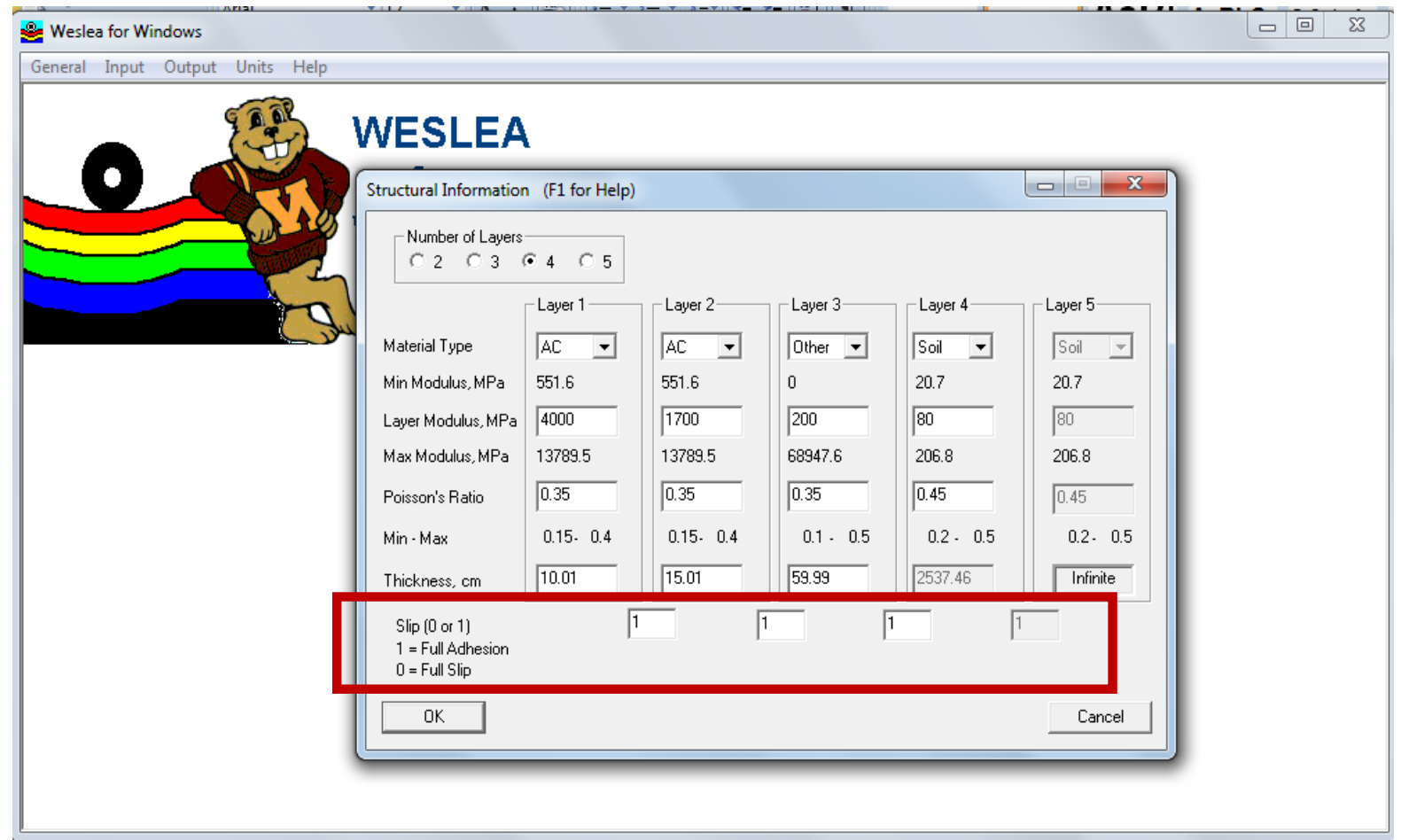

Figura 2.3 - Interface gráfica do software WESLEA para análise de aderência total ou nula

Para pavimentos flexíveis geralmente são testadas as tensões e as deformações de tração nas fibras inferiores das camadas asfálticas e as deformações de compressão e tensões no topo do subleito. Os valores de tensão e deformação na fibra inferior da camada asfáltica nova para casos de total aderência 
e casos com total escorregamento são apresentados comparativamente na Tabela 2.1.

Tabela 2.1 - Resultados de tensão e deformação na fibra inferior da camada asfáltica nova para total aderência e total escorregamento

\begin{tabular}{ccc}
\hline & Total Aderência & Total Escorregamento \\
\hline Tensão de Tração Horizontal (kPa) & $-222,34$ & $-1148,16$ \\
Deformação de Tração Horizontal (10E-6) & $-68,93$ & $-233,35$ \\
\hline
\end{tabular}

As duas situações extremas (total aderência e total escorregamento), porém, não representam uma condição real. Geralmente, a interface entre duas camadas asfálticas não está nem totalmente aderida, nem totalmente descolada (ROMANOSCHI e METCALF, 2001b). Romanoschi e Metcalf (2001b) modelaram um sistema multi-camadas, por meio do software de elementos finitos $A B A Q U S^{1}$, para testar a influência de diferentes graus de aderência na distribuição de tensões na estrutura, sujeita a cargas horizontais (aceleração e frenagem de veículos, por exemplo). O Método dos Elementos Finitos (MEF) permite considerar, em análises estruturais de pavimentos, o comportamento não linear dos materiais, a descontinuidade das camadas (fissuras e interface), o carregamento dinâmico e o efeito da temperatura (ROMANOSCHI e METCALF, 2001b).

Os parâmetros que alimentaram o modelo descrito pelos autores (apresentados na Figura 2.4) derivaram de resultados, em laboratório, de ensaios de cisalhamento direto na interface. São eles: a) a inclinação da curva resultante de tensão versus deslocamento até a tensão cisalhante máxima, denominada módulo de reação na interface $\mathrm{K}$; b) a própria tensão cisalhante máxima; e c) o coeficiente de atrito após ruptura, $\mu$ (dependente de uma tensão normal aplicada durante 0 ensaio).

\footnotetext{
${ }^{1}$ Pacote de software para análise de estruturas por Método de Elementos Finitos (http://www.3ds.com/products/simulia/portfolio/abaqus/overview).
} 


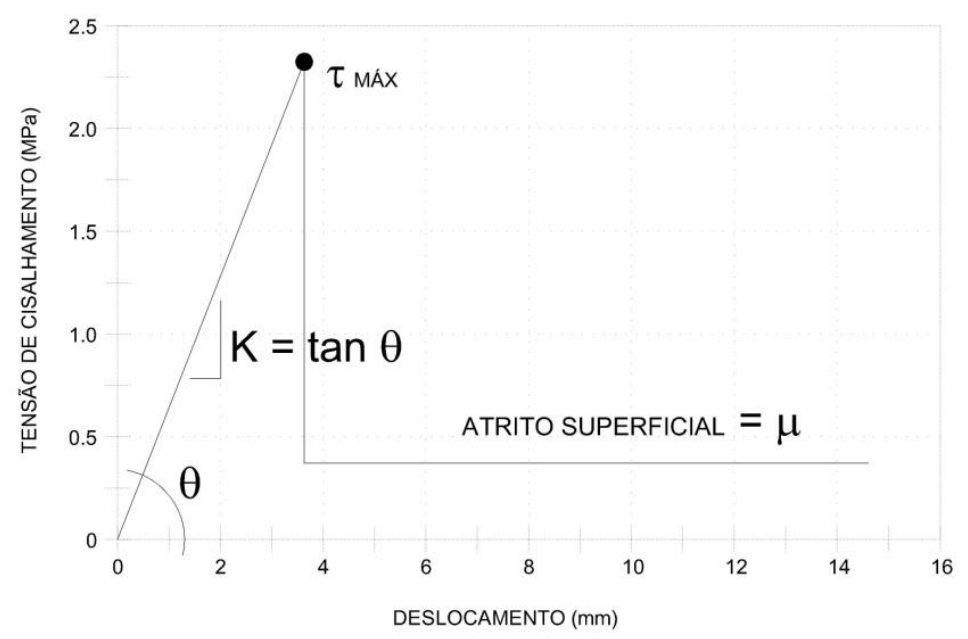

Figura 2.4 - Parâmetros de entrada para avaliar a interface entre camadas, adaptado de Romanoschi e Metcalf (2001b)

Para uma estrutura semi-rígida, composta por camada asfáltica superficial, binder, base cimentada e subleito, os resultados mostraram que as tensões horizontais no topo e na fibra inferior da camada superficial são significativamente influenciadas pelas condições da interface. Quando havia completa aderência no contato entre as camadas asfálticas, a camada superficial, com $3,8 \mathrm{~cm}$, apresentou tensões de compressão. Nos casos de aderência parcial ou nula nesta interface, a distribuição de tensões mudou gradativamente, de forma que a camada superficial passou a trabalhar no domínio da tração na fibra inferior. O ponto crítico de tensão (deformação de tração máxima) estaria então localizado na fibra inferior da camada asfáltica superficial, indicando o provável local de início do trincamento por fadiga.

A mesma análise foi feita para a camada de binder $(5 \mathrm{~cm})$, que apresentou tensões de compressão quando a superfície em contato com a base estava em total aderência e tensões de tração quando a interface não estava aderida.

Kruntcheva et al. (2005), por meio do software BISAR, analisaram o desempenho do pavimento para diversos graus de aderência na interface entre camadas asfálticas e entre camada asfáltica e base. $O$ software de dimensionamento elástico linear considera, da mesma forma que o ABAQUS, o módulo de reação ao cisalhamento horizontal $(K)$ definido pela inclinação na curva de tensão versus cisalhamento. Para casos de total escorregamento, os autores 
encontraram redução na vida de fadiga e aumento da deformação permanente de mais de $80 \%$ em comparação aos casos de total aderência.

O aumento das tensões, gerado for falhas de aderência, diminui a vida de serviço das estruturas dimensionadas e causa patologias estruturais como mostram as Figuras 2.5 e 2.6. Na interface, as duas camadas se deslocam em direções diferentes, destruindo o vínculo existente entre elas e provocando trincamento precoce da camada superficial (MOHAMMAD et al., 2012). O trincamento por escorregamento entre camadas é caracterizado por fissuras parabólicas em meia lua, geralmente na direção do tráfego e em áreas sujeitas frequentemente à frenagem e aceleração - rampas, curvas de raio pequeno, intersecções e paradas de ônibus (HUANG, 1993; MOHAMMAD et al., 2002; ROMANOSCHI e METCALF, 2001a) (Figura 2.4). Considerar um fator de aderência na interface, ainda em fase de dimensionamento dos pavimentos, pode levar à redução no número de intervenções e custos com manutenção das estruturas.

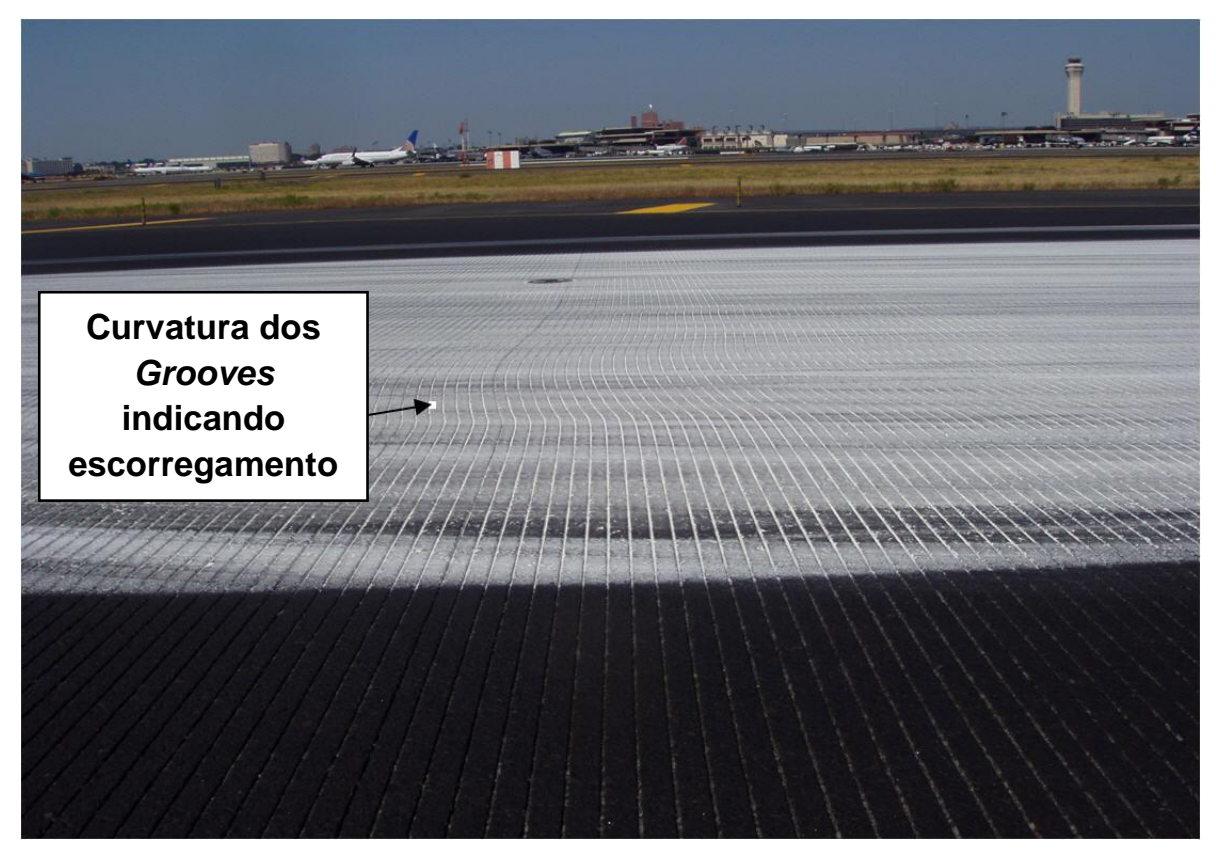

Figura 2.5 - Escorregamento de camada superficial asfáltica perceptível pela curvatura dos groovings. Pavimento do Newark International Airport, New Jersey, EUA (BOGNACKI et al., 2007) 


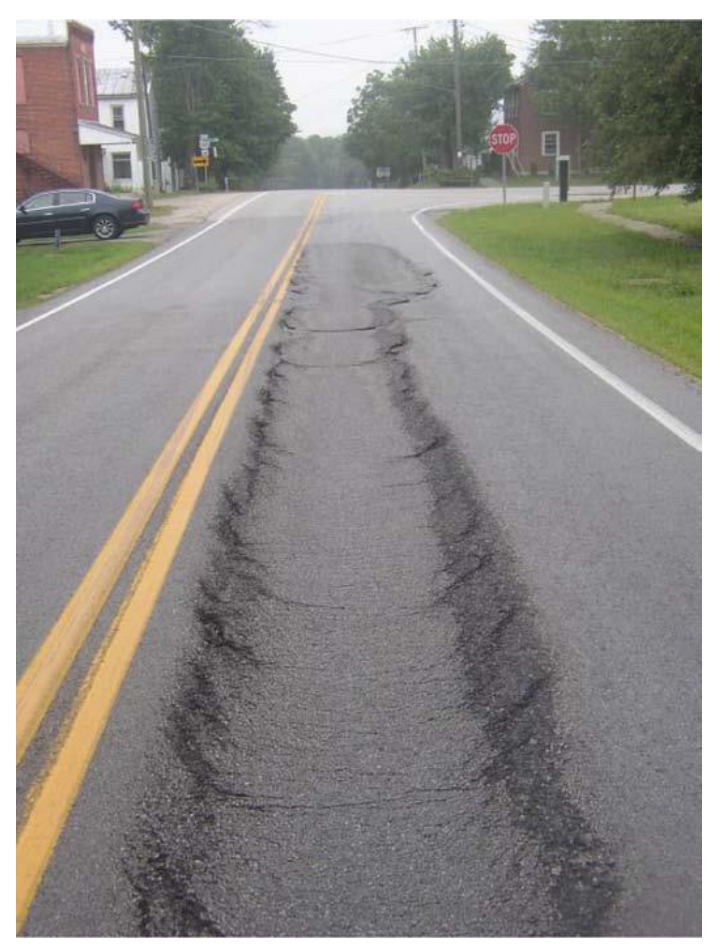

Figura 2.6 - Trincamento por escorregamento entre camadas (MOHAMMAD et al., 2012)

\subsection{A PINTURA DE LIGAÇÃO}

A pintura de ligação, como mencionado anteriormente, é a aplicação de uma película delgada de um material betuminoso entre camadas asfálticas de pavimento. Apesar da pintura de ligação constituir um dos elementos de menor custo nas obras de pavimentação, este é imprescindível para possibilitar a aderência entre duas camadas asfálticas e aumentar a durabilidade dos revestimentos. Como pintura de ligação podem ser usadas emulsões asfálticas (asphalt emulsions) ou, em casos mais raros, o próprio ligante asfáltico (paving grade asphalt binders) (CHEN e HUANG, 2010; MOHAMMAD et al., 2002).

As emulsões asfálticas são os materiais betuminosos mais utilizados para pintura de ligação e, por isso, serão tratados com maior detalhe neste trabalho. Resultantes da mistura de ligante asfáltico e água, por meio de um agente emulsificante, possuem baixa viscosidade a baixas temperaturas, permitindo fácil aplicação em campo. A proporção entre água (de 25 a 60\%), ligante (40 a 75\%) e emulsificante $(0,1$ a $0,5 \%)$ depende de fatores como: característica do CAP, tipo de agente emulsificante e a viscosidade desejada para a emulsão (SALOMON, 2006). 
Segundo Salomon (2006), no processo de produção das emulsões, o cimento asfáltico aquecido e a água contendo um agente emulsificador são misturados, sob pressão, em um moinho coloidal. Do produto saem glóbulos micrométricos de CAP suspensos na água, mistura que só é relativamente estável devido à presença do agente emulsificante.

A quebra do asfalto em glóbulos inicia-se mecanicamente dentro do moinho coloidal, mas é dificultada pela viscosidade do CAP e pela tensão superficial que resiste à criação de novas interfaces. O agente emulsificante diminui a tensão interfacial entre asfalto e água, o que além de facilitar a quebra em glóbulos estabiliza a emulsão obtida. A superfície dos glóbulos de asfalto passa ainda a ter uma carga elétrica, que pode ser aniônica ou catiônica a depender do agente emulsificante utilizado. Se o emulsificante é um sulfato de sódio, as emulsões irão adquirir carga negativa e serão denominadas aniônicas (BERNUCCI et al., 2008). Por outro lado, se o emulsificante for do tipo amina, a carga adquirida é positiva e as emulsões serão denominadas catiônicas. Os glóbulos de CAP, com a mesma carga elétrica, vão se repelir e, pela bipolaridade do emulsificante, irão se aderir às moléculas de água (Figura 2.7).

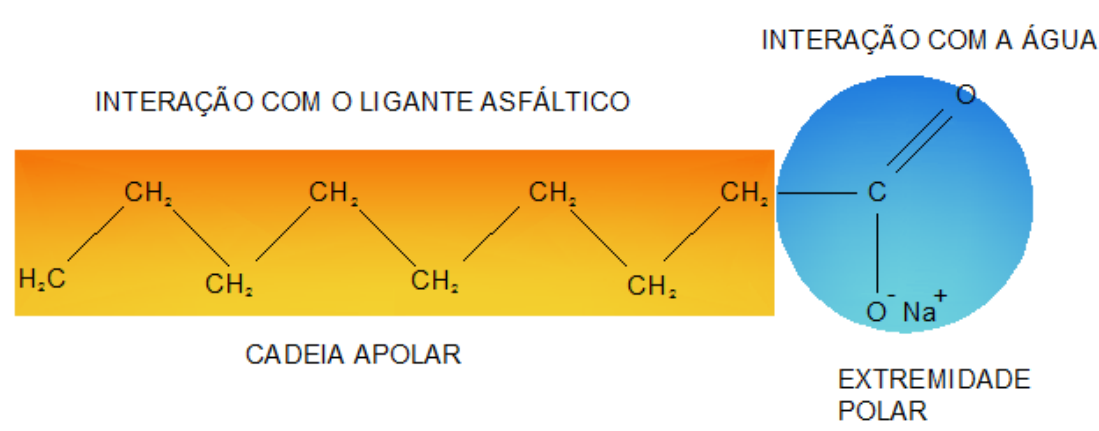

Figura 2.7 - Bipolaridade do composto emulsificante

A polaridade dos glóbulos de CAP e, portanto, da emulsão asfáltica obtida (aniônica ou catiônica) é caracterizada por meio do Ensaio de Carga de Partícula (NBR 6567). A emulsão deve ter carga oposta à carga da superfície do agregado utilizado para garantir que a pintura de ligação configure um bom contato entre as camadas (CHEN e HUANG, 2010).

O processo de evaporação da água e floculação dos glóbulos de asfaltos é conhecido como ruptura da emulsão. A ruptura pode ser rápida, média ou lenta, a 
depender do tipo e quantidade de emulsificante da mistura (BERNUCCI et al., 2008). O início do processo se dá no contato com o agregado ou com a camada asfáltica antiga, quando a água é liberada e evapora (processo físico) ou inicia-se uma reação química entre a fase dispersa (asfalto) e a superfície de contato (adsorção do emulsificante). A velocidade da ruptura depende de vários fatores:

- Viscosidade do ligante residual;

- Concentração de ligante;

- Quantidade de emulsificante;

- Utilização de agregados reativos e sua superfície específica; e

- Temperatura do ambiente e dos materiais.

A execução da camada superior de revestimento ou recapeamento só pode ser iniciada após a ruptura total da emulsão, que é evidenciada pela alteração da coloração marrom para preta (MOHAMMAD et al., 2012). Deve-se atentar ao tipo de ruptura especificada (lenta, média, rápida ou controlada), em função do clima ou horário de aplicação. As emulsões de ruptura lenta, muito utilizadas nos EUA, por exemplo, não são recomendadas para aplicações em dias frios, à noite, ou em obras com cronograma estreito (PAUL e SCHEROCMAN, 1998).

No Brasil, as emulsões são classificadas, segundo PINTO (2008), em:

- Catiônicas (C) ou Aniônicas (A), a depender da carga elétrica adquirida no processo de emulsificação (positiva ou negativa, respectivamente);

- RL (Ruptura Lenta), RM (Ruptura Média) e RR (Ruptura Rápida), de acordo com o tempo de ruptura;

- 1 ou 2, em função crescente da sua viscosidade; e

- E, se modificadas por polímeros.

Em outros países, a nomenclatura segue classificação semelhante. No Departamento de Transporte da Califórnia (CALTRANS, 2009), por exemplo, a notação normatizada é dada como:

- Catiônicas (C) ou Aniônicas (quando não há indicação);

- SS (Slow Setting), RS (Rapid Setting) e QS (Quick Setting), em função do tempo de ruptura; 
- 1 ou 2, em função crescente da sua viscosidade;

- LM (Latex modified), HF (High Float), P (Polymer modified), quando modificadas; e

- h ao final da nomenclatura significa presença de ligante com baixa penetração.

As emulsões catiônicas de ruptura rápida do tipo RR-1C e RR-2C, ou emulsões de ruptura rápida modificadas por polímero, são as mais utilizadas como pintura de ligação por recomendação de órgãos normatizadores nacionais (DNIT, 1997; DNIT, 2010; DER-SP, 2005; DER-PR, 2005).

A execução da pintura de ligação deve ser feita após limpeza da superfície, retirando o pó e o material solto, principalmente nos casos em que haja serviço de fresagem. A Figura 2.8 mostra a aplicação da emulsão por meio de barra espargidora. A pintura de ligação deve ser aplicada de forma uniforme por toda a superfície a ser recapeada. O uso de "caneta" (Figura 2.9) deve se restringir a casos de "falhas de bico", onde não há cobertura total por falha pontual da barra espargidora. A emulsão deve ser aplicada à determinada taxa residual e seu controle é feito por meio de pesagem, em campo, de bandejas com área conhecida, impregnadas com o ligante asfáltico (MOHAMMAD et al., 2012).

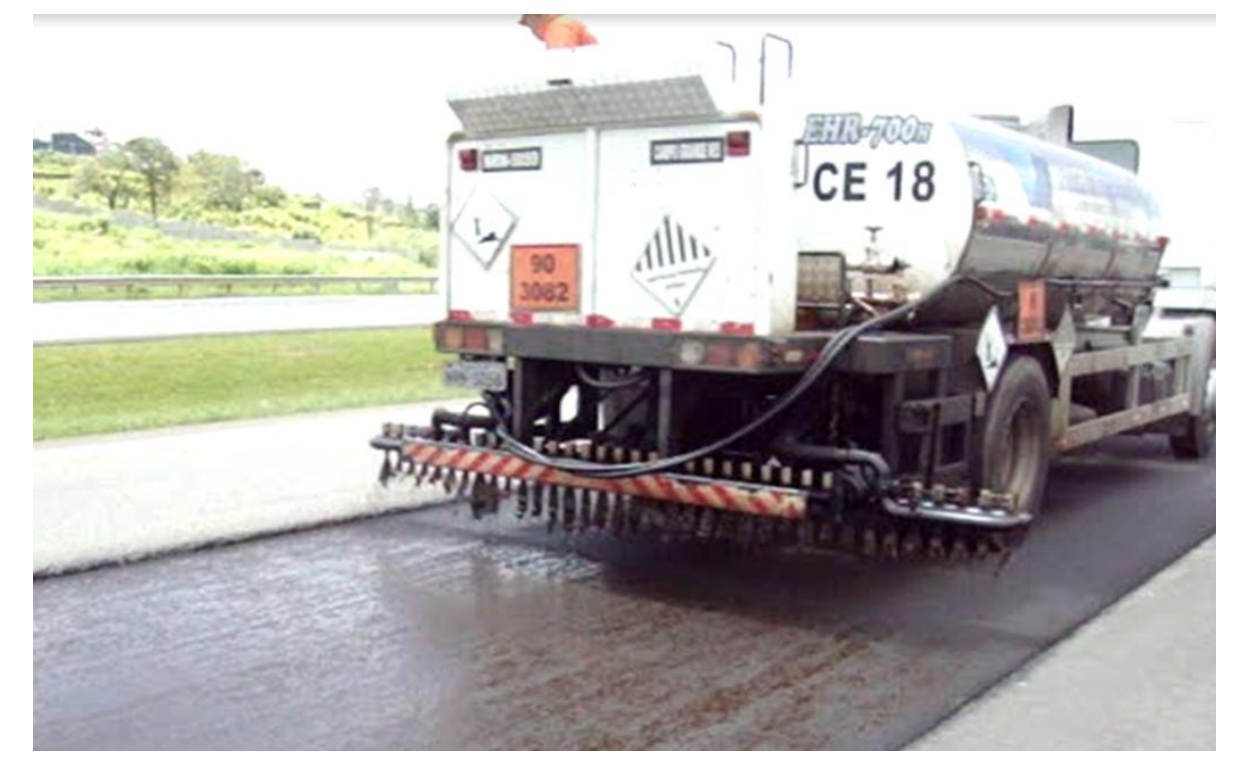

Figura 2.8 - Aplicação de emulsão asfáltica como pintura de ligação por meio de barra espargidora 


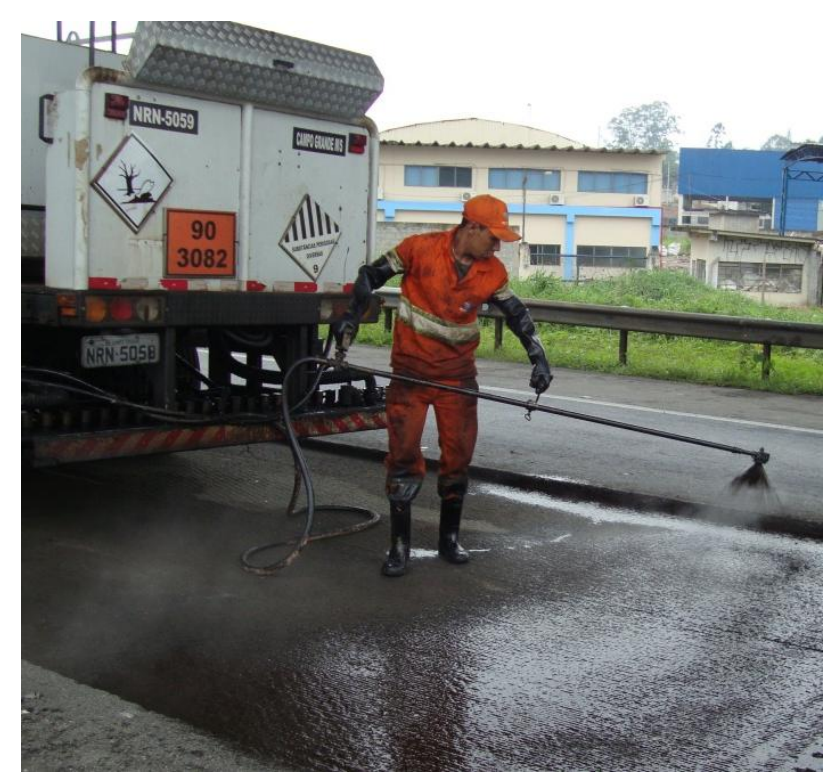

Figura 2.9 - Aplicação de emulsão asfáltica como pintura de ligação por meio de caneta

As várias normas e especificações de serviço no Brasil sugerem diferentes intervalos para taxa de aplicação da pintura de ligação. Segundo DNIT (2010) 145/2010-ES, as emulsões asfálticas devem ser aplicadas a taxas que variam de 0,3 a $0,4 \mathrm{~L} / \mathrm{m}^{2}$ de ligante residual. Na especificação de serviço do DER-SP (DER-SP, 2005), a taxa indicada de resíduo asfáltico é de 0,3 a 0,5 L/m². Para o DER-PR (2005) a taxa de aplicação em campo é descrita no intervalo de 0,5 a 0,8 L/m² de emulsão asfáltica, sendo a taxa de resíduo determinada em função do ensaio de resíduo por evaporação (NBR 6368 para emulsões convencionais e NBR 14896 para emulsões modificadas). Lavin (2003) recomenda taxas de aplicação de 0,2 a $1,0 \mathrm{~L} / \mathrm{m}^{2}$ de emulsão, sendo o último valor referente ao caso de superfícies fresadas ou com misturas de graduação aberta. Barksdale (1991) sugere taxas de aplicação de ligante residual aproximadas de 0,3 a $0,8 \mathrm{~L} / \mathrm{m}^{2}$.

A falta de pintura de ligação é associada à baixa aderência entre camadas. Por outro lado, o excesso de ligante cria um filme mais espesso e deformável, que diminui o atrito e o intertravamento entre as camadas (CHEN e HUANG, 2010), causando escorregamento entre elas (TASHMAN, 2006). Existe uma taxa ótima de aplicação que constitui, portanto, um fator preponderante para garantir boa aderência entre camadas.

Segundo Mohammad et al. (2002), para qualquer tipo de pintura de ligação a taxa ótima de aplicação corresponde a um valor de resistência ao cisalhamento 
máxima (pico do gráfico de tensão de cisalhamento direto versus teor de emulsão). Os autores testaram, por meio de ensaio de cisalhamento a carregamento constante de $50 \mathrm{lb} / \mathrm{min}$, o efeito de diferentes materiais de pintura de ligação (emulsões CRS2P; SS-1; CSS-1; SS-1h; e ligantes PG 64-22 e PG 76-22, este último com polímero) e de diferentes taxas de aplicação de ligante residual $(0,00,0,09,0,23,0,45$ e 0,90 $\mathrm{L} / \mathrm{m}^{2}$ ) na resistência ao cisalhamento da interface entre as camadas. A emulsão que apresentou melhores resultados foi a CRS-2P (catiônica de ruptura rápida modificada por polímero) com taxa de aplicação de $0,09 \mathrm{~L} / \mathrm{m}^{2}$ para temperatura de 25ㄷ. Uzan et al. (1978) utilizaram em seus estudos ligante asfáltico Pen 60-70, com variação de taxas de aplicação de emulsão de 0,0, 0,49, 0,97, 1,46 e 1,94L/m², obtendo como taxas ótimas (maior resistência ao cisalhamento) 0,49 e 0,97 L/m² a $2^{\circ} \mathrm{C}$ e $55^{\circ} \mathrm{C}$, respectivamente. O ensaio de cisalhamento direto, neste caso, foi realizado a deslocamento constante de $2,5 \mathrm{~mm} / \mathrm{min}$. Hachiya e Sato (1997) testaram comparativamente emulsões asfálticas convencionais e modificadas. Encontraram melhor resposta de tensão cisalhante máxima para a emulsão modificada, com taxa de aplicação ótima de $0,18 \mathrm{~L} / \mathrm{m}^{2}$.

Os estudos têm resultados diferentes devido principalmente à influência do tipo de pintura, da superfície das amostras e das condições de ensaio (equipamentos, velocidade e temperatura). Para obras de restauração que contemplam fresagem antes do recapeamento, a taxa de aplicação necessária pode ser maior que a normalmente recomendada. Isso se deve à superfície áspera e irregular resultante da fresagem (CHEN e HUANG, 2010).

Acredita-se ainda que a viscosidade da pintura de ligação influencie na aderência entre camadas. Chen e Huang (2010) e Mohammad et al. (2002) em seus estudos concluíram que o melhor tipo de pintura é a CRS 2P, emulsão que atingiu maior viscosidade no ensaio Brookfield (2,03 Pa-s) após 2hs de cura. West et al. (2005) avaliaram dois tipos de emulsão e um ligante asfáltico. Os resultados também demonstraram a importância da viscosidade como parâmetro influenciador da aderência entre as camadas. 


\subsection{SISTEMAS ANTI-REFLEXÃO DE TRINCAS - GEOTÊXTEIS E GRELHAS}

Existem hoje no mercado diversos materiais utilizados em obras rodoviárias e geotécnicas, desempenhando funções como reforço de fundações e taludes, filtração, drenagem, proteção e separação entre materiais, impermeabilização e controle de erosões. Apesar de lançados no Brasil em 1970, esses materiais começaram a ser difundidos e amplamente utilizados apenas na década de 1990 (COSTA et al., 2008).

As grelhas e os geotêxteis, nas obras de pavimentação, são aplicados como reforço estrutural do pavimento. Seja em obras de novos pavimentos ou obras de restauração de pavimentos já existentes, esses materiais são aplicados com o objetivo de aumentar a resistência mecânica do conjunto, melhorar a impermeabilização do sistema e retardar a reflexão de trincas provenientes das camadas subjacentes. A literatura acerca da reabilitação de pavimentos, e mais especificamente $\mathrm{o}$ recapeamento de pavimentos deteriorados com concreto asfáltico, aponta o uso de geotêxteis e grelhas na interface entre camadas como eficiente sistema para retardamento da reflexão de trincas (VANELSTRAETE et al., 1997; MONTESTRUQUE, 2002; FIORIN, 2009; CORREIA, 2010).

Montestruque (2002) e Fiorin (2009) estudaram o desempenho de fadiga na implantação de camadas intermediárias de geotêxtil, observando redução no tempo de propagação do trincamento na camada asfáltica nova. Vanelstraete et al. (1997) já indicavam que o uso de geossintéticos entre camadas cria uma zona de descontinuidade viscoelástica que minimiza a intensidade das tensões sobre a trinca existente no momento da solicitação de carga. Outros estudos analisam também o ganho de resistência à tração de geossintéticos quando impregnados com ligante asfáltico (CORREIA, 2010).

A presença desses materiais na interface entre camadas pode configurar também um ponto frágil no contato e na aderência entre elas, causando problemas como escorregamento e descolamento já discutidos nesse capítulo. 


\subsubsection{Características dos materiais}

As principais características técnicas dos materiais de reforço para pavimento são (VANELSTRAETE et al., 1997):

- Tipo de material, que pode ser poliéster, polipropileno, fibra de vidro, fibra de aço, ou de carbono;

- Espessura;

- Abertura da malha (no caso de grelhas);

- Resistência máxima, medida com ensaios de tração direta nas direções longitudinal e transversal (já que geralmente são produtos anisotrópicos);

- Deformação máxima (\%);

- Rigidez do produto e das juntas, essa última em caso de grelhas $(\mathrm{kN} / \mathrm{m})$;

- Módulo de rigidez ou elasticidade do material (MPa);

- Susceptibilidade a variações térmicas;

- Absorção de material betuminoso (caso de geotêxteis não-tecidos).

Os geotêxteis são produtos bidimensionais e permeáveis, compostos por fibras cortadas ou filamentos contínuos poliméricos, distribuídos aleatoriamente e interligados por processos mecânicos, térmicos ou químicos. Podem ser tecidos ou não-tecidos e, esses últimos, agulhados ou não, a depender do seu processo de fabricação. Para obras de pavimentação asfáltica, os geotêxteis mais recomendados são os não-tecidos agulhados de poliéster (DER-SP, 2006).

Para que possam ser utilizados em sistemas anti-reflexão de trincas, a especificação do DER-SP (2006) ET-DE-P00/043 indica as seguintes propriedades para os geotêxteis:

- Resistência à tração no sentido de menor resistência, conforme NBR 12824 (ABNT, 1993): maior que $7,0 \mathrm{kN} / \mathrm{m}$ para pavimentos com trincamento pouco severo, pequena área e tráfego leve; maior que 8,0 $\mathrm{kN} / \mathrm{m}$ para pavimentos com trincamento de severidade média e tráfego médio e 9,0 kN/m para pavimentos com trincamento de severidade alta e tráfego de médio a pesado; 
- Resistência ao puncionamento, conforme NBR 13359 (ABNT, 1995): maior que 1,3, 1,7 e 2,0 kN, segundo diferentes condições do pavimento existente e do tráfego citadas acima, respectivamente;

- Capacidade de retenção de ligante betuminoso maior que 0,9L/m² (ASTM D6140 (2009));

- Ponto de amolecimento maior que $180^{\circ} \mathrm{C}$ (ASTM D7138 (2008)).

As grelhas são geralmente fabricadas com material polimérico ou com fibras, que podem ser de vidro ou carbono, impregnadas ou não com material betuminoso. São produzidas por extrusão, soldadas ou tecidas.

A especificação do DER-SP para tratamentos anti-reflexão de trincas (DER-SP, 2006) indica a utilização de grelhas poliméricas (geogrelhas), com as seguintes características:

- Força de tração máxima maior que $50 \mathrm{kN} / \mathrm{m}$ para deformação menor que 12\%, conforme NBR 12824 (ABNT, 1993);

- Resistência à fadiga maior que $90 \%$ de resistência retida após 100.000 ciclos;

- Malha com abertura suficiente para permitir a acomodação dos agregados mais graúdos em seu interior (a menor dimensão da abertura da malha tem que ser no mínimo 2 e no máximo 10 vezes superior ao diâmetro máximo do agregado);

- Ponto de amolecimento maior que $180^{\circ} \mathrm{C}$.

As grelhas de fibra de vidro e de carbono têm suas especificações divulgadas por fornecedores, com valores que variam entre:

- Força de tração máxima com valores na ordem de $111 \mathrm{kN} / \mathrm{m}$ para fibras de vidro e $250 \mathrm{kN} / \mathrm{m}$ para fibras de carbono, e deformações de $2,7 \%$ e $1,5 \%$, respectivamente;

- Módulo de elasticidade de $73 \mathrm{kN} / \mathrm{mm}^{2}$ para grelhas de fibra de vidro e $240 \mathrm{kN} / \mathrm{mm}^{2}$ para as fibras de carbono. 


\subsubsection{Processo de aplicação em campo}

A aplicação dos geotêxteis entre camadas deve prever as seguintes etapas (DER-SP, 2006):

- Aplicação da primeira pintura de ligação, com 70 a $80 \%$ da taxa de asfalto residual total prevista em projeto, sobre superfície limpa;

- Instalação do geotêxtil, por processo manual ou mecânico (pendurais), tomando-se os devidos cuidados para eliminar a formação de ondulações ou rugas;

- Caso ocorram eventuais enrugamentos na manta aplicada, devem ser eliminados através de corte e emenda com sobreposição mínima;

- As emendas devem ser feitas com sobreposição de 10 a 15cm e aplicação de sobretaxa de asfalto para garantir perfeita impregnação. Evitar emendas nas divisões de faixa de tráfego e regiões com solicitações de carga de roda;

- Compactação sobre o geotêxtil, com duas ou três passadas de rolo de pneu de baixa pressão $(0,28$ a $0,35 \mathrm{MPa})$ para induzir a penetração invertida do ligante no geotêxtil. Uma coloração parda indicará que a etapa foi devidamente cumprida;

- Aplicação da segunda pintura de ligação, com o valor de taxa que falta para atingir a taxa total prevista (geralmente, de 20 a 30\%);

- Salgamento eventual da superfície, com a própria mistura asfáltica a ser aplicada, para evitar que o geotêxtil impregnado seja aderido às rodas dos caminhões ou esteira da vibroacabadora;

- Aplicação e compactação da mistura asfáltica, com espessura mínima de $3,0 \mathrm{~cm}$.

A cada aplicação da pintura de ligação deve-se aguardar o tempo necessário para ruptura da emulsão. Em obras de restauração, deve-se prever, antes do início da instalação do geotêxtil, a fresagem da superfície (quando indicado em projeto) e correção dos defeitos localizados, depressões e irregularidades. A selagem das trincas com aplicação de asfalto, lama asfáltica ou mistura betuminosa e limpeza da superfície também são etapas que contribuirão para o bom desempenho da solução. 
As taxas de aplicação de pintura de ligação entre camadas indicadas para o caso da utilização de geotêxtil em obras de restauração, segundo especificação ETDE-P00/043 DER-SP (2006) deve seguir a equação abaixo:

$$
Q_{D}=0,36+Q_{S} \pm Q_{C}
$$

Onde:

$$
\begin{aligned}
& Q_{D} \text { - quantidade de ligante de projeto }\left(\mathrm{L} / \mathrm{m}^{2}\right) ; \\
& Q_{S} \text { - índice de saturação do geotêxtil a ser utilizado }\left(\mathrm{L} / \mathrm{m}^{2}\right) ; \\
& Q_{C} \text { - correção baseada na demanda necessária pela superfície do } \\
& \text { pavimento existente }\left(\mathrm{L} / \mathrm{m}^{2}\right) \text {. }
\end{aligned}
$$

Os valores de correção em função da superfície estão descritos na Tabela 2.2 abaixo:

Tabela 2.2 - Valores de correção da taxa de aplicação em função das condições superficiais do pavimento existente (DER-SP, 2006)

\begin{tabular}{cc}
\hline CONDIÇÕES DA SUPERFÍcIE & $\mathbf{Q}_{\mathbf{C}}\left(\mathbf{L} / \mathbf{m}^{2}\right)$ \\
\hline Nivelado & $-0,09$ a 0,09 \\
Liso, não poroso & 0,09 a 0,23 \\
Ligeiramente poroso e ligeiramente oxidado & 0,23 a 0,36 \\
Ligeiramente poroso e oxidado & 0,36 a 0,50 \\
Poroso e oxidado & 0,50 a 0,59 \\
\hline
\end{tabular}

O índice de saturação do geotêxtil (Qs), valor fornecido geralmente pelo fabricante, foi estudado por Wickert (2003), para alguns tipos de geotêxteis. O resultado para o ensaio de absorção de asfalto com um geotêxtil não-tecido agulhado, de poliéster, foi em média de $1,08 \mathrm{~L} / \mathrm{m}^{2}$. Aplicando esse valor na Equação 2.1, sem considerar a correção em função das condições da superfície de aplicação, o que aumentaria o valor do resultado, a taxa de aplicação mínima indicada seria, neste caso, de $1,44 \mathrm{~L} / \mathrm{m}^{2}$.

Os valores de taxa de aplicação recomendados por um fabricante para o mesmo tipo de geotêxtil (não tecido agulhado) são:

- Força de tração máxima de $8 \mathrm{kN} / \mathrm{m}: 0,8$ a $1,0 \mathrm{~L} / \mathrm{m}^{2}$; 
- Força de tração máxima de $9 \mathrm{kN} / \mathrm{m}: 1,0$ a 1,2 L/m²;

- Força de tração máxima de $10 \mathrm{kN} / \mathrm{m}: 1,1$ a $1,3 \mathrm{~L} / \mathrm{m}^{2}$.

A aplicação das grelhas em campo segue metodologia semelhante. Não há compactação sobre o material e a pintura de ligação é aplicada somente sobre a superfície da camada asfáltica, antes da colocação da grelha. A taxa de pintura de ligação residual aplicada deve variar entre $0,4 \mathrm{~L} / \mathrm{m}^{2}$ e $0,6 \mathrm{~L} / \mathrm{m}^{2}$ (DER-SP, 2006) para as geogrelhas. Para grelhas de fibra de vidro e carbono, os valores recomendados são, em ambas as grelhas, de 0,2 a 0,5 L/m² de emulsão modificada com 60 a $70 \%$ de polímero, de acordo com especificações de um fabricante.

\subsubsection{Materiais de reforço anti-reflexão de trincas e a aderência entre camadas}

A literatura acerca do uso de geotêxteis e grelhas como reforço de pavimento desenvolveu-se com o estudo do comportamento mecânico dessas estruturas e de sua resposta frente ao fenômeno de reflexão de trincas. Além do desempenho desses sistemas de reforço, a aderência entre as camadas que o integram deve ser testada, já que os materiais sintéticos podem configurar um ponto de fragilidade no contato entre as camadas do pavimento e desencadear uma série de defeitos de descolamento e escorregamento das pistas.

Poucos trabalhos analisam o uso dessas soluções e sua influência na aderência entre camadas. Montestruque (1996), por meio de ensaios de fadiga à flexão alternada em vigotas prismáticas, estudou o ganho incorporado pela presença de geossintético, no fenômeno de reflexão de trincas. O mesmo trabalho indica que a melhoria na resistência à formação de trincas se deve a uma interface (revestimento asfáltico e geogrelha/geotêxtil) perfeitamente aderida. E essa aderência é obtida com impregnação do material pela pintura de ligação.

Vanelstraete et al. (1997) citam a importância dos testes de absorção de betume em geotêxteis, porque a concentração insuficiente de ligante leva a problemas de delaminação (descolamento). Indicam ainda que o excesso de ligante também pode causar problemas, principalmente durante a instalação do material na obra. 
Montestruque et al. (2011) estudaram a aderência entre camadas asfálticas em corpos de prova cilíndricos sujeitos a ensaios de cisalhamento, com e sem a presença de geogrelha na interface, variando ainda a taxa de pintura de ligação aplicada. Menor aderência foi percebida entre camadas com a presença do geossintético, devido à área ocupada pela malha da grelha. A taxa de pintura de ligação ótima obtida para a solução com geogrelha foi maior que nos casos sem o uso do material sintético na interface.

Raab e Partl (2004) estudaram a aderência entre camadas de pavimento comparando amostras com o uso de fibra de vidro, tela de aço, ou somente pintura de ligação na interface. Os resultados demonstraram que a presença desses materiais na interface afeta negativamente o contato entre as camadas.

Bazarra et al. (2010) testaram a influência do uso de geotêxteis e grelhas poliméricas na aderência, variando também a taxa de aplicação de pintura de ligação. Para os casos com uso de geotêxtil, os resultados de tensão de cisalhamento máxima apresentaram-se muito inferiores aos casos com grelha e sem nenhum material na interface. Para o uso de grelha, os resultados apontaram uma taxa ótima de ligante residual de $0,30 \mathrm{~L} / \mathrm{m}^{2}$ e tensões de cisalhamento próximas aos valores obtidos em amostras somente com pintura de ligação.

A influência no intertravamento mecânico existente entre as camadas, e ainda, o valor de taxa ótima para que a estrutura se comporte monoliticamente, ainda devem ser melhor estudados.

\subsection{SUPERFÍCIE DE CONTATO E O INTERTRAVAMENTO ENTRE AS CAMADAS}

A macrotextura superficial das misturas asfálticas tem influência direta no valor de resistência ao cisalhamento. No estudo realizado por Raposeiras et al. (2012), os autores observaram que para misturas asfálticas com valores mínimos de macrotextura, a taxa ótima de pintura de ligação estaria abaixo do exigido pela especificação espanhola. O efeito da rugosidade da superfície na resistência ao cisalhamento na interface também foi investigado por Mohammad et al. (2010). Os autores acharam uma correlação direta entre os dois parâmetros quando compararam superfícies fresadas com superfícies não fresadas, onde a primeira 
levou a valores de resistência ao cisalhamento superiores, independente do tipo de pintura de ligação utilizada.

Chen e Huang (2010) estudaram a aderência na interface de diferentes composições de misturas: CBUQ-CBUQ, CBUQ-CPA (Camada Porosa de Atrito), SMA (Stone Matrix Asphalt) - CPA. A resistência ao cisalhamento apresentou maiores valores na composição CBUQ-CBUQ, devido a maior área superficial de contato entre as camadas. Os valores da macrotextura de cada mistura foram medidos com ensaio de mancha de areia. Para condições de boa compactação, o intertravamento entre as camadas ajuda a evitar escorregamentos, à medida que o agregado de uma camada penetra na outra camada. Concluiu-se que quanto maior o valor obtido no ensaio de mancha de areia, mais fácil é esse intertravamento. Mesmo após a ocorrência da ruptura (pico de resistência), o intertravamento ainda ajuda a manter as camadas aderidas.

O DER-PR indica, conforme apresentado na Tabela 2.3 , os valores recomendados para taxa da pintura de ligação em função da textura e condições superficiais das camadas.

Tabela 2.3 - Valores recomendados pelo DER-PR para taxa de pintura de ligação (DER-PR, 2005)

\begin{tabular}{lc}
\hline \multicolumn{1}{c}{ Textura Superficial } & Taxa de Aplicação de Emulsão \\
\hline Revestimentos asfálticos abertos ou porosos e envelhecidos & 0,6 a $0,8 \mathrm{~L} / \mathrm{m}^{2}$ \\
Revestimentos asfálticos semi-densos e densos envelhecidos & 0,5 a $0,7 \mathrm{~L} / \mathrm{m}^{2}$ \\
Camadas graunulares recém construídas e imprimadas & 0,5 a $0,6 \mathrm{~L} / \mathrm{m}^{2}$ \\
$\begin{array}{l}\text { Camadas de solos estabilizados, tratados ou não, recém } \\
\text { construídos e com pintura de proteção de cura }\end{array}$ & 0,3 a $0,5 \mathrm{~L} / \mathrm{m}^{2}$ \\
$\begin{array}{l}\text { Camadas de perfilagem com CBUQ em serviços de } \\
\text { restauração de pavimentos }\end{array}$ & 0,3 a $0,4 \mathrm{~L} / \mathrm{m}^{2}$ \\
\hline
\end{tabular}

\subsection{MEDIDAS DE ADERÊNCIA ENTRE CAMADAS}

A aderência, na literatura internacional, é avaliada a partir da ruptura da camada de ligação por ensaios de cisalhamento direto ou torque, a uma taxa de carregamento constante ou a uma taxa de deslocamento constante (carregamentos monotônicos). Com menor frequência, são também relatados ensaios de 
arrancamento (com aplicação de uma força de tração direta para separação das duas camadas).

Entre as principais metodologias utilizadas nos ensaios de cisalhamento podem ser citadas: Ensaios de Cisalhamento Direto (Figura 2.10) com aplicação de carga vertical normal e velocidade de deslocamento horizontal de $2,5 \mathrm{~mm} / \mathrm{min}$ (UZAN et al., 1978; CHEN e HUANG, 2010); ensaios com o Ancona Shear Testing Research and Analysis (ASTRA), semelhante ao ensaio de cisalhamento direto (ver Figura 2.11) (SANTAGATA et al., 2009; CANESTRARI et al., 2005); Leutner Shear Test (Figura 2.12), equipamento desenvolvido na Alemanha, em 1979, que aplica uma força de cisalhamento vertical direto em corpos de prova cilíndricos de $150 \mathrm{~mm}$ de diâmetro e velocidade de deslocamento vertical de 50mm/min (COLLOP et al., 2003;2009); Layer-Parallel Direct Shear Device (LPDS) (ver Figura 2.13), versão suíça modificada para o equipamento Leutner (SANTAGATA et al., 2009; RAAB e PARTL, 2004; CANESTRARI et al., 2005); Louisiana Interlayer Shear Strength Tester (LISST), que aplica, como no ensaio Leutner, um carregamento monotônico vertical para induzir o cisalhamento no plano da interface e, ao mesmo tempo, uma força normal na direção horizontal (Figura 2.14); e ensaios de tração direta (Pull-off tests) (RAAB e PARTL, 2004).

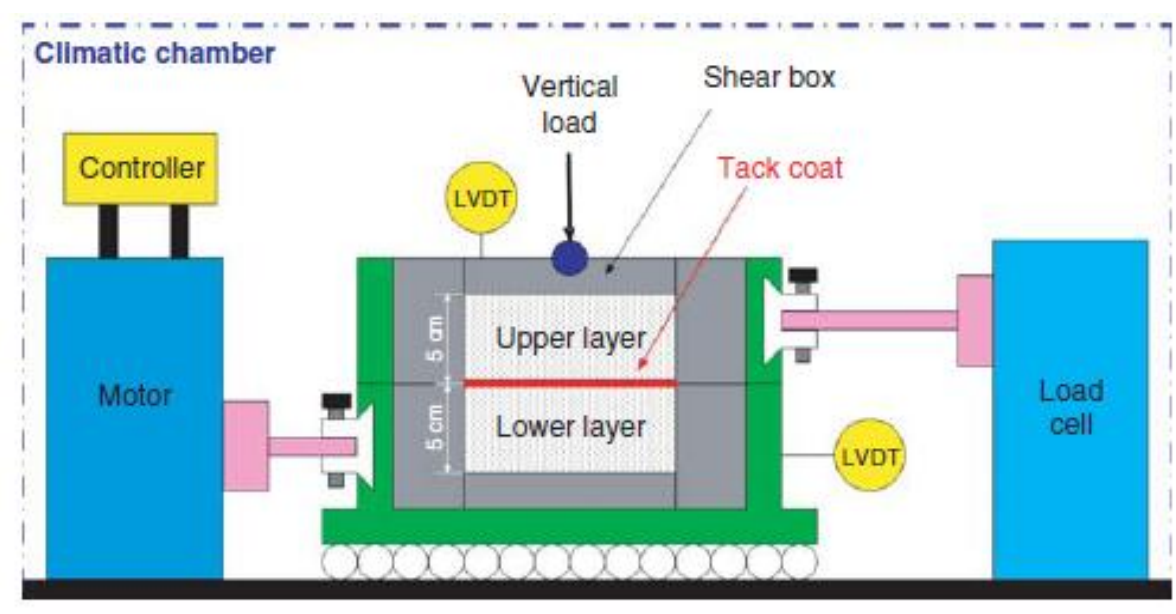

Figura 2.10 - Ensaio de cisalhamento direto com aplicação de carga vertical normal (CHEN e HUANG, 2010) 


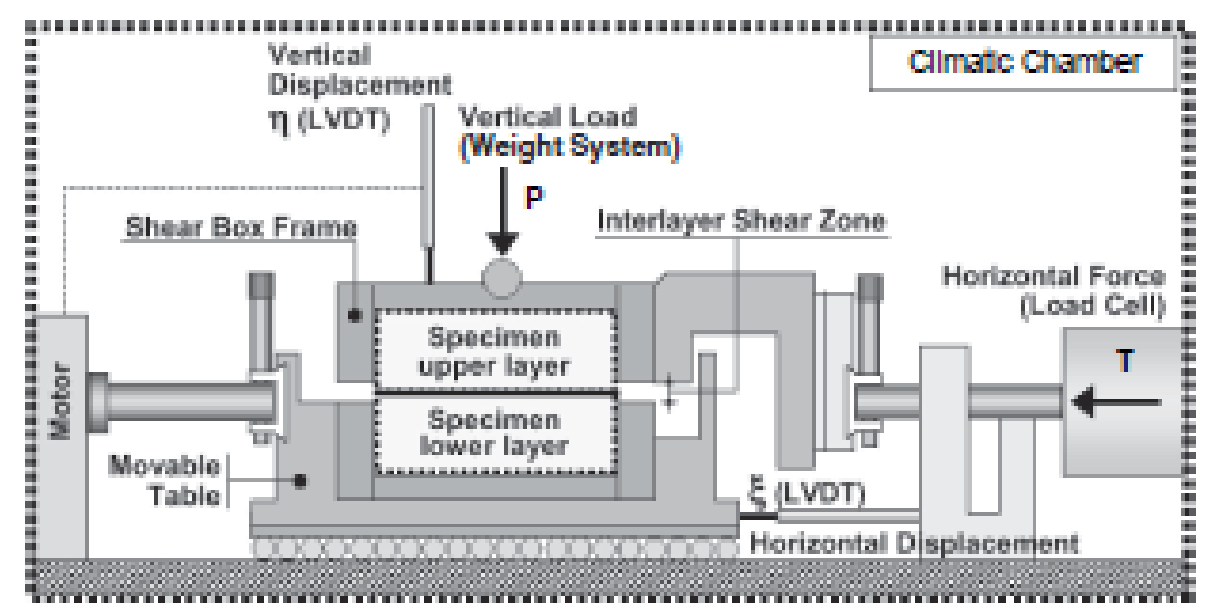

Figura 2.11 - ASTRA (CANESTRARI et al., 2005; SANTAGATA et al., 2009)

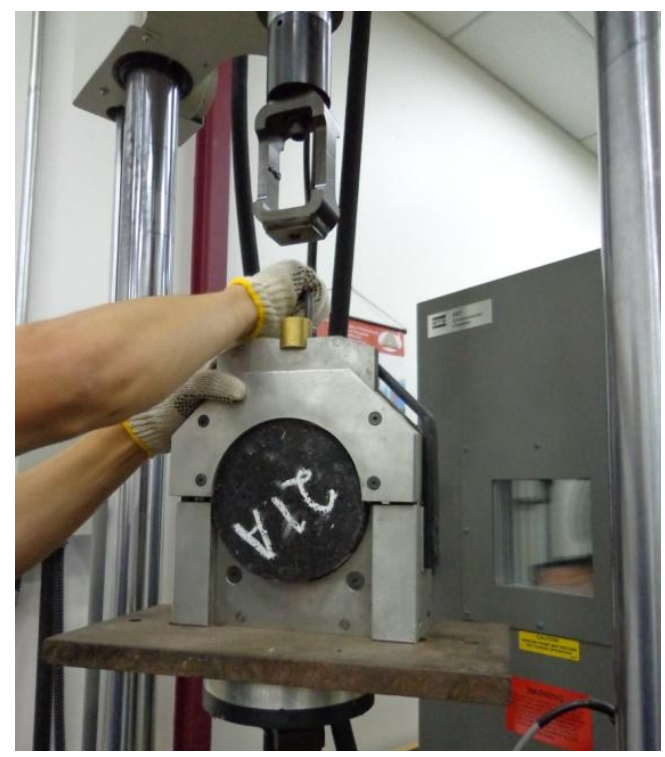

Figura 2.12 - Leutner Shear Test (Laboratório de Tecnologia de Pavimentação - Escola Politécnica da USP)
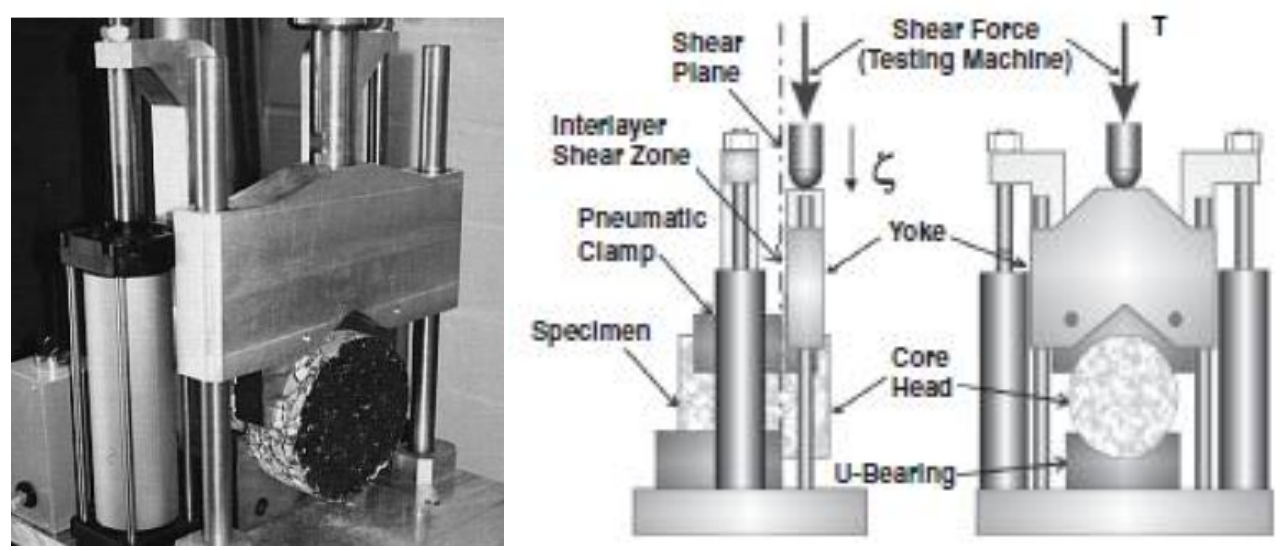

Figura 2.13 - LPDS (CANESTRARI et al., 2005; RAAB e PARTL, 2004; SANTAGATA et al., 2009) 

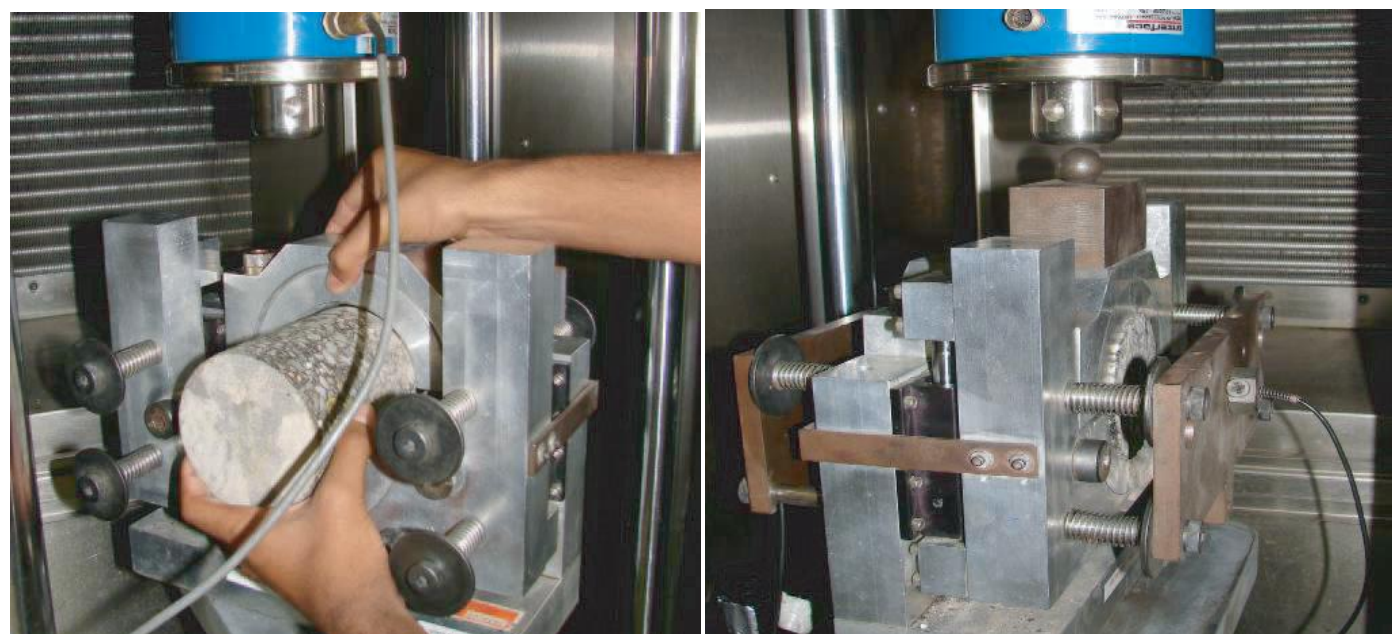

Figura 2.14 - LISST (MOHAMMAD et al., 2012)

Tashman et al. (2006) citam alguns ensaios existentes como ATTACKER (Introtek Inc), NCAT Shear Test, Superpave Shear Test (SST), e avaliam, comparativamente, a força de aderência entre camadas através do cisalhamento vertical no Florida Dot Shear Tester (FDST) (Figura 2.15), da tração direta no Utep Pull off Test (UPOT) (Figura 2.16) e da força cisalhante de torção no Torque Bond Test (Figura 2.17), com aplicação de uma emulsão asfáltica catiônica de ruptura lenta do tipo CSS-1.

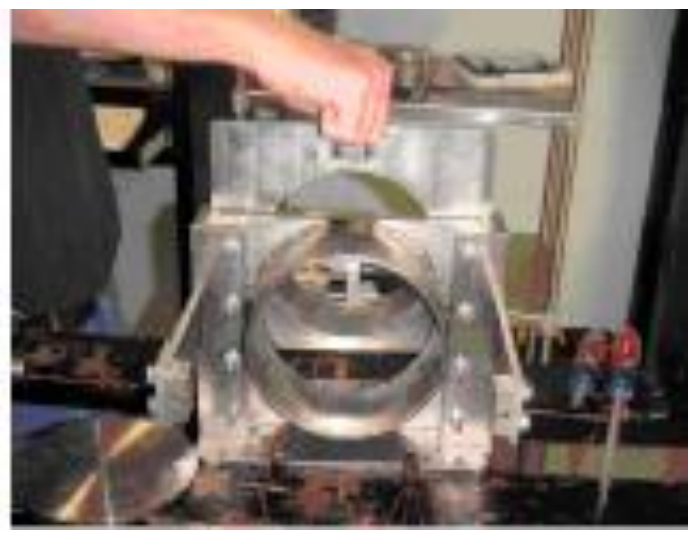

Figura 2.15 - FDST - Florida DoT Shear Tester (TASHMAN et al., 2006) 


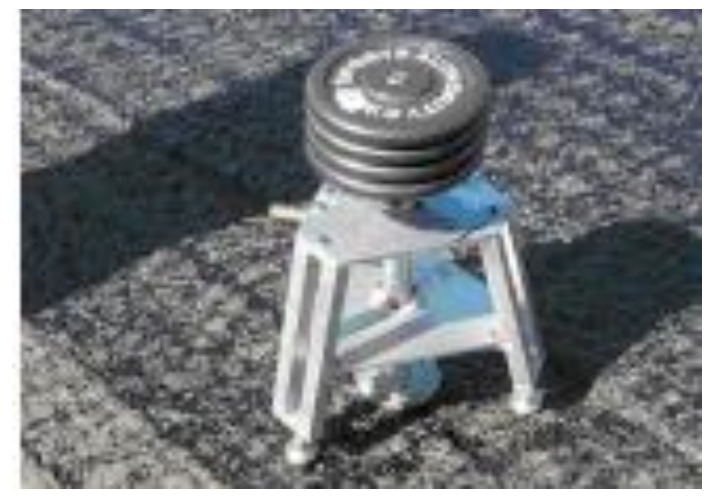

Figura 2.16 - UPOT - Utep Pull-off Test (TASHMAN et al., 2006)

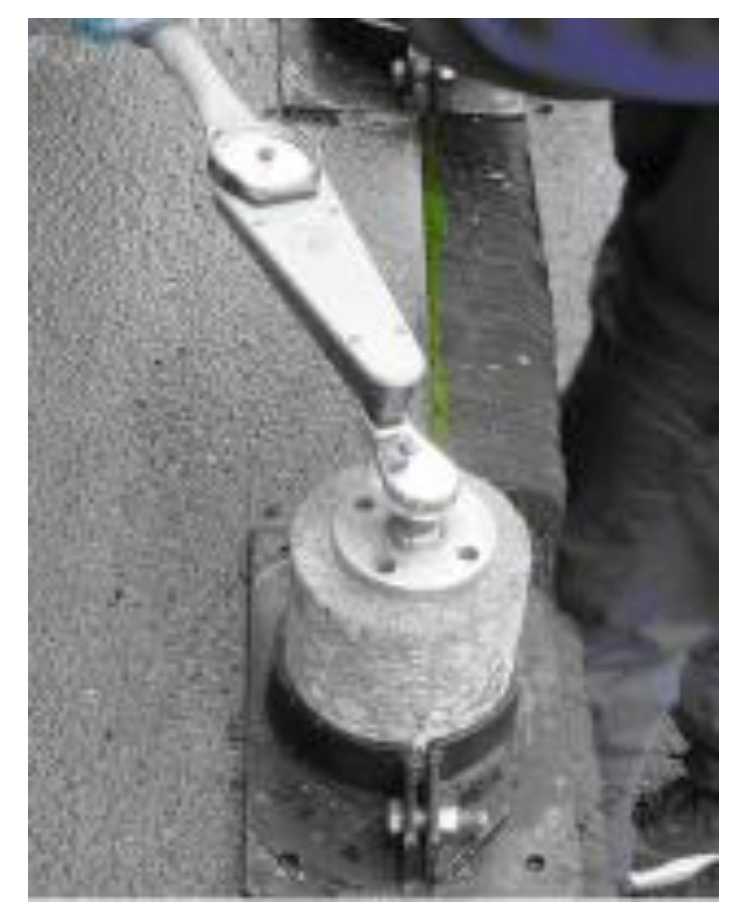

Figura 2.17 - Torque Bond Test (TASHMAN et al., 2006)

As metodologias citadas acima utilizam o pico do gráfico tensão versus deslocamento como parâmetro para avaliação da resistência ao cisalhamento (SANTAGATA et al., 2009).

Collop et al. (2003; 2009) por meio do Leutner Shear Test avaliaram as condições de interface entre camadas para diferentes tipos de pinturas de ligação e diferentes taxas de aplicação, estabelecendo uma relação entre a tensão e a deformação de cisalhamento. Raab e Partl (2004) analisaram a aderência entre camadas por meio do ensaio LPDS, normatizado pela Schweizer Norm 671961 de 
2000, em corpos de prova de $150 \mathrm{~mm}$, com velocidade de aplicação de carga de $50,8 \mathrm{~mm} / \mathrm{min}$.

Santagata et al. (2009) estudaram estatisticamente 0 desempenho do equipamento suíço Layer-Parallel Direct Shear (LPDS) comparando-o com o italiano Ancona Shear Testing Research and Analysis (ASTRA). Os autores concluíram que os equipamentos, apesar de diferentes, geram resultados comparáveis entre si, com coeficiente de variação médio de 25\%. O ASTRA, normatizado pela UNI/TS 11214 de 2007, possui uma caixa de cisalhamento direto que permite aplicação de uma tensão normal (vertical) de 0,2 MPa e, ao mesmo tempo, uma força horizontal de cisalhamento com taxa de deslocamento constante de $2,5 \mathrm{~mm} / \mathrm{min}$. Os corpos de prova, neste caso, são de 100 mm. 


\section{MATERIAIS E MÉTODOS}

Um sistema de duas camadas foi preparado para avaliar a aderência entre camadas asfálticas com diferentes tipos e taxas de aplicação de pinturas de ligação e o uso ou não de geotêxtil e grelha na interface. Foram utilizadas duas misturas asfálticas: uma camada tipo SAMI (Stress Absorbing Membrane Interlayer) e uma camada de CBUQ (Concreto Betuminoso Usinado a Quente), ambas integrantes de um sistema proposto como solução de restauração para mitigação de problemas de trincas por reflexão. Três tipos de emulsão asfáltica, uma convencional e duas modificadas por polímero, foram aplicados na interface entre as camadas, com variação nas taxas de aplicação. A correção da real taxa aplicada (ligante residual) foi feita com base em ensaio de resíduo por evaporação, descrito adiante. As misturas asfálticas foram coletadas na Usina PSI, em março de 2012, e os materiais levados ao Laboratório de Tecnologia de Pavimentos (LTP) da Escola Politécnica da USP (EPUSP).

Foram moldadas 2 placas para cada combinação e, de cada placa, foram extraídos dois corpos de prova cilíndricos com $150 \mathrm{~mm}$ de diâmetro. Em cada corpo de prova realizou-se ensaio de cisalhamento direto Leutner, com o objetivo de avaliar: (i) a existência de uma taxa ótima de aplicação de pintura de ligação e (ii) a influência do uso dos geotêxtil e da grelha nessa taxa.

Para os casos com aplicação somente de pintura de ligação na interface extraiu-se também um corpo de prova de $100 \mathrm{~mm}$ de diâmetro no centro da placa, com objetivo de analisar a influência da dimensão das amostras nos resultados do ensaio de cisalhamento. Foi ainda investigado(a):

- Um sistema com dupla camada de $\mathrm{CBUQ}$ (CBUQ+CBUQ), variando apenas a taxa de aplicação de emulsão convencional, com objetivo de investigar a influência da textura superficial na aderência entre camadas;

- A velocidade de ensaio (carregamento monotônico a $50 \mathrm{~mm} / \mathrm{min}$ e $1 \mathrm{~mm} / \mathrm{min}$ ) para amostras com pintura de ligação e taxa de 0,25 
$\mathrm{L} / \mathrm{m}^{2}$, com os dois tipos de emulsão (convencional e modificada por polímero);

- Influência da posição do broqueamento dos corpos de prova de $100 \mathrm{~mm}$ e $150 \mathrm{~mm}$ nas placas.

Os seguintes materiais foram utilizados para moldagem das amostras em laboratório:

- Mistura asfáltica do tipo CBUQ;

- Mistura asfáltica do tipo SAMI;

- Emulsão asfáltica RR-1C convencional (Emulsão 1);

- Emulsão asfáltica RR-1C-E modificada por polímero (Emulsão 2);

- Emulsão asfáltica RR-2C-E modificada por polímero (Emulsão 3);

- Grelha de Fibra de Vidro;

- Geotêxtil não tecido agulhado.

A matriz de ensaios e a quantidade de amostras seguem descritas na Tabela 3.1. As duas cores apresentadas nas células da Tabela diferenciam a matriz de ensaio proposta inicialmente para esta pesquisa, dos ensaios complementares realizados após obtenção dos resultados do primeiro grupo. A justificativa da divisão da matriz de ensaios será novamente abordada no Capítulo 4. 
Tabela 3.1 - Matriz da programação de ensaios de cisalhamento com quantidade de amostras moldadas em laboratório

\begin{tabular}{|c|c|c|c|c|c|c|c|}
\hline \multirow[b]{2}{*}{$\begin{array}{l}\text { Tipo de } \\
\text { Emulsão }\end{array}$} & \multirow{2}{*}{$\begin{array}{c}\text { Taxa de } \\
\text { aplicação } \\
\text { de Pintura } \\
\text { de } \\
\text { Ligação } \\
\left(\mathrm{L} / \mathrm{m}^{2}\right) \\
\end{array}$} & \multicolumn{5}{|c|}{ (SAMI+CBUQ) } & \multirow{2}{*}{$\begin{array}{c}\text { CBUQ+CBUQ } \\
\begin{array}{c}\text { Pintura de } \\
\text { Ligação }\end{array} \\
\end{array}$} \\
\hline & & $\begin{array}{l}\text { Pintura de } \\
\text { Ligação }\end{array}$ & $\begin{array}{l}\text { Pintura + } \\
\text { Geotêxtil }\end{array}$ & Pintura + Grelha & $\begin{array}{c}\text { Reduzida } \\
\text { (1mm/min) - } \\
\text { Somente pintura }\end{array}$ & $\begin{array}{l}\text { diferente } \\
\text { (Somente } \\
\text { pintura) }\end{array}$ & \\
\hline- & 0 & $x$ & $x$ & $x$ & & & $x$ \\
\hline \multirow{4}{*}{$\begin{array}{l}\text { EMULSÃO } 1 \\
\text { RR-1C }\end{array}$} & 0,25 & $x$ & $x$ & $x$ & $x$ & $x$ & $x$ \\
\hline & 0,75 & $x$ & $x$ & $x$ & & & $x$ \\
\hline & 1 & & $x$ & & & & $x$ \\
\hline & 1,25 & & $x$ & & & & \\
\hline \multirow{2}{*}{$\begin{array}{c}\text { EMULSÃO } 2 \\
\text { RR-1C-E }\end{array}$} & 0,25 & $x$ & $x$ & $x$ & $x$ & & \\
\hline & 0,5 & $x$ & $x$ & $x$ & & & \\
\hline \multirow{4}{*}{$\begin{array}{l}\text { EMULSÃO } 3 \\
\text { RR-2C-E }\end{array}$} & 0,5 & $x$ & & & & & \\
\hline & 0,75 & $x$ & & & & & \\
\hline & & & & \multicolumn{4}{|c|}{ Matriz inicialmente proposta } \\
\hline & & & & \multicolumn{4}{|c|}{ Matriz complementar } \\
\hline
\end{tabular}




\subsection{CARACTERIZAÇÃO DOS MATERIAIS}

\subsubsection{Projeto das misturas asfálticas}

As misturas de CBUQ e SAMI foram preparadas e coletadas na usina PSI (Pedreira e Pavimentadora Santa Isabel) localizada em Santa Isabel-SP, em Março de 2012. Após a coleta as misturas foram levadas ao Laboratório de Tecnologia de Pavimentos (LTP), em latas de 18L, conforme ilustrado na Figura 3.1. Os ligantes asfálticos utilizados para produção de ambas as misturas (SAMI e CBUQ) são modificados com polímero do tipo SBS. A caracterização dos ligantes encontra-se apresentada na Tabela 3.2 a seguir. Os agregados utilizados para produção da mistura foram coletados na própria Pedreira Santa Isabel. A granulometria das misturas está apresentada na Figura 3.2.

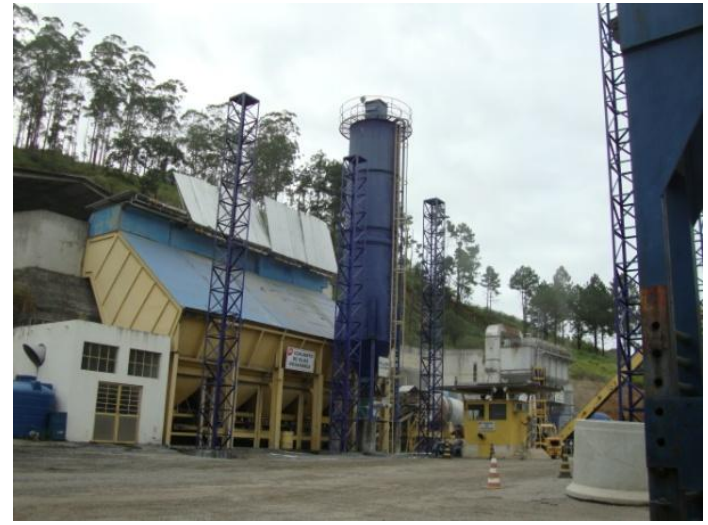

(a)

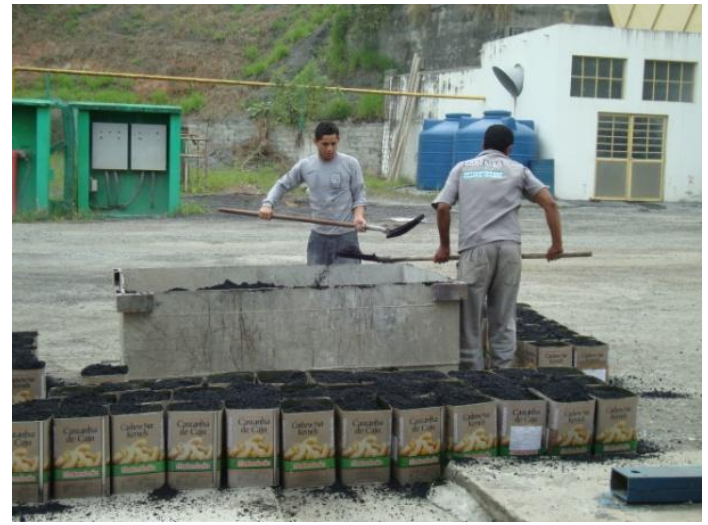

(b)

Figura 3.1 - (a) Visão geral da usina; (b) Material coletado para envio ao LTP/EPUSP 
Tabela 3.2 - Caracterização do ligante asfáltico utilizado nas misturas

\begin{tabular}{|c|c|c|c|c|}
\hline \multicolumn{2}{|c|}{ Características } & Método & $\begin{array}{c}\text { CAP com } \\
\text { PG70-28 } \\
\text { SAMI }\end{array}$ & $\begin{array}{c}\text { CAP com } \\
\text { PG76-22 } \\
\text { CBUQ }\end{array}$ \\
\hline \multicolumn{2}{|c|}{$\begin{array}{l}\text { Penetração, } 100 \mathrm{~g}, 5 \mathrm{~s}, 25^{\circ} \mathrm{C} \\
(0,1 \mathrm{~mm})\end{array}$} & NBR-6576 & 74 & 57 \\
\hline \multicolumn{2}{|c|}{ Ponto de Fulgor $\left({ }^{\circ} \mathrm{C}\right)$} & NBR-11341 & $>235$ & $>235$ \\
\hline \multicolumn{2}{|c|}{ Ponto de Amolecimento $\left({ }^{\circ} \mathrm{C}\right)$} & NBR-6560 & 80 & 63 \\
\hline \multicolumn{2}{|c|}{$\begin{array}{l}\text { Recuperação Elástica, } 20 \mathrm{~cm} \text {, } \\
25^{\circ} \mathrm{C}(\%)\end{array}$} & NBR-15086 & 96 & 89 \\
\hline $\begin{array}{l}\text { Viscosidade } \\
\text { Brookfield } \\
\text { (cP) }\end{array}$ & $\begin{array}{l}135^{\circ} \mathrm{C}-\mathrm{S} 21 \\
20 \mathrm{rpm} \\
150^{\circ} \mathrm{C}-\mathrm{S} 21 \\
50 \mathrm{rpm} \\
177^{\circ} \mathrm{C}-\mathrm{S} 21 \\
100 \mathrm{rpm}\end{array}$ & NBR-15184 & $\begin{array}{l}620 \\
266\end{array}$ & $\begin{array}{l}568 \\
205\end{array}$ \\
\hline \multicolumn{2}{|c|}{$\begin{array}{l}\text { Estabilidade a Estocagem Dif. } \\
\text { Ponto de Amolecimento }\left({ }^{\circ} \mathrm{C}\right)\end{array}$} & NBR-15166 & 2 & - \\
\hline
\end{tabular}

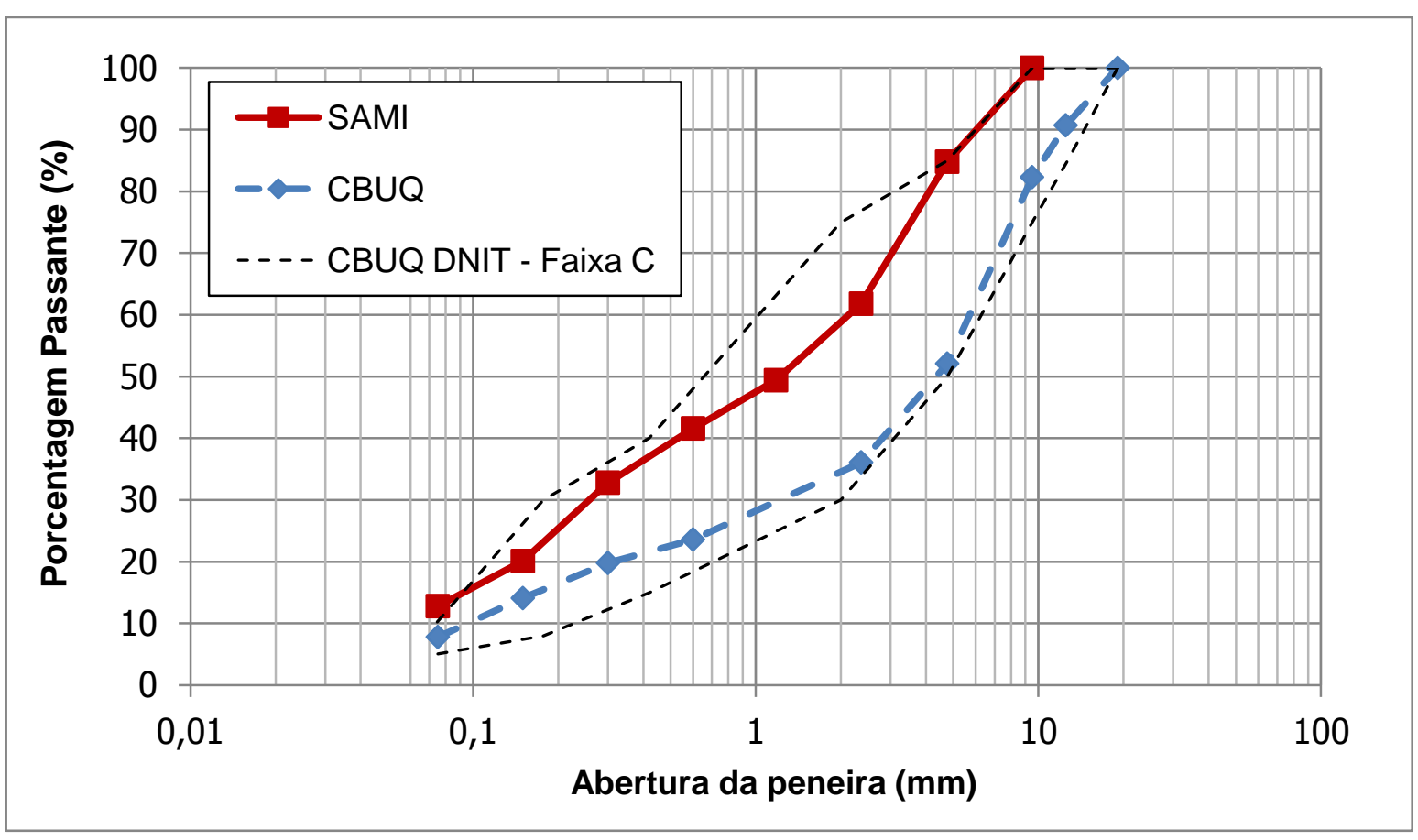

Figura 3.2 - Granulometria das misturas de CBUQ e SAMI

A mistura de SAMI, com teor de betume igual a 7,2\% e volume de vazios de $2,4 \%$, é mais fina e apresenta maior deformabilidade após compactação. O CBUQ apresentou teor de betume igual a 4,8\% e volume de vazios de 4,9\%. O valor da densidade aparente foi de 2,482 e 2,492 para o SAMI e o CBUQ, respectivamente. Os ensaios e especificações referentes às misturas e aos ligantes utilizados para produção do SAMI e do CBUQ estão nos Anexos F, G, H e I. 


\subsubsection{Emulsões asfálticas utilizadas nas pinturas de ligação}

Foram utilizadas três emulsões asfálticas como pintura de ligação para o estudo de aderência na interface de camadas: uma emulsão convencional do tipo RR-1C e duas modificadas por polímero SBR, RR-1C-E e RR-2C-E (ver especificações das emulsões nos anexos A, B e C). Verificou-se o percentual de asfalto residual nas três emulsões (Figura 3.3), segundo normas NBR 14367 e 14896 (ABNT, 2004; 2007). As amostras foram deixadas em estufa a $130^{\circ} \mathrm{C}$ por tempo suficiente para que toda a água fosse evaporada. A Emulsão 1 apresentou $58,2 \%$ de asfalto residual, a Emulsão 2, 65,0\% e a Emulsão 3, 67,6\%. A Tabela 3.3 traz em detalhes os resultados obtidos no ensaio de resíduo por evaporação.
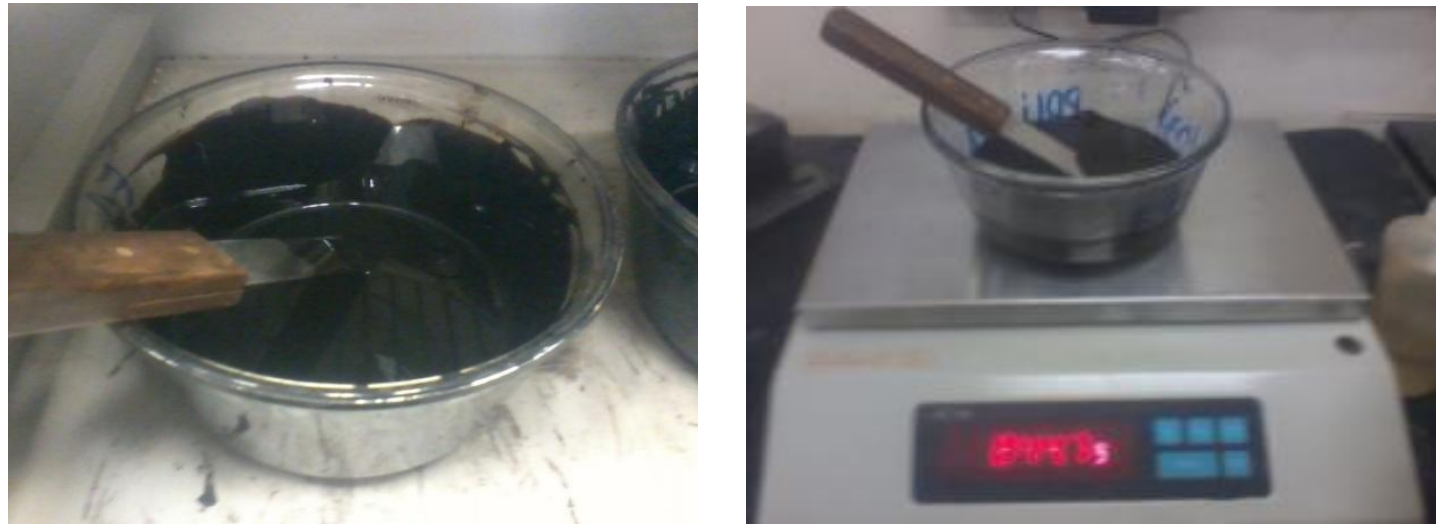

Figura 3.3 - Determinação do resíduo por evaporação

Tabela 3.3 - Resultado do ensaio de resíduo por evaporação

\begin{tabular}{|c|c|c|c|c|c|c|}
\hline & \multicolumn{2}{|c|}{$\begin{array}{c}\text { Emulsão } 1 \\
\text { RR-1C }\end{array}$} & \multicolumn{2}{|c|}{$\begin{array}{c}\text { Emulsão } 2 \\
\text { RR-1C-E }\end{array}$} & \multicolumn{2}{|c|}{$\begin{array}{c}\text { Emulsão } 3 \\
\text { RR-2C-E }\end{array}$} \\
\hline Recipiente + Espátula (A) & $\begin{array}{l}(19 / 06) \\
\text { Horário }\end{array}$ & $\begin{array}{c}\text { Massa }(\mathbf{g}) \\
529,49\end{array}$ & $\begin{array}{c}(19 / 06) \\
\text { Horário }\end{array}$ & $\begin{array}{c}\text { Massa } \\
(\mathbf{g}) \\
539,19\end{array}$ & $\begin{array}{l}(15 / 11) \\
\text { Horário }\end{array}$ & $\begin{array}{c}\text { Massa } \\
(\mathbf{g}) \\
321,74\end{array}$ \\
\hline Recipiente + Espátula + Emulsão (B0) & $12: 55$ & 844,79 & $12: 55$ & 845,19 & $07: 45$ & 421,88 \\
\hline Emulsão & & 315,3 & & 306 & & 100,14 \\
\hline B1 & $17: 20$ & 748,59 & $17: 20$ & 772,49 & 09:00 & 396,96 \\
\hline B2 & $18: 00$ & 737,49 & $18: 00$ & 760,09 & $09: 45$ & 390,42 \\
\hline B3 & 19:11 & 721,09 & 19:11 & 748,69 & $10: 30$ & 389,52 \\
\hline B4 & $19: 35$ & 716,79 & $19: 35$ & 743,69 & $11: 30$ & 389,44 \\
\hline B5 & $20: 50$ & 712,69 & $20: 50$ & 738,79 & $12: 00$ & 389,42 \\
\hline B6 & $21: 20$ & 712,79 & $21: 20$ & 738,49 & $13: 00$ & 389,41 \\
\hline B7 & $21: 35$ & 712,69 & $21: 35$ & 738,09 & - & - \\
\hline B8 & 22:05 & 712,69 & 22:05 & 738,09 & - & - \\
\hline Recipiente + Espátula + Emulsão (C ) & $22: 15$ & 712,89 & $22: 15$ & 738,19 & $13: 30$ & 389,41 \\
\hline \% Resíduo & & 58,2 & & 65,0 & & 67,6 \\
\hline
\end{tabular}


Também foi realizado ensaio de viscosidade Brookfield no ligante asfáltico residual em temperaturas de 135,150 e $175^{\circ} \mathrm{C}$, spindle $\mathrm{S} 21$ (em todos os casos) e velocidades de 20, 50 e 100 RPM, para as emulsões modificadas e 30, 60 e 100 RPM para a Emulsão 1 (convencional). A Figura 3.4 (a) a (h) abaixo apresenta a sequência de execução dos dois ensaios:

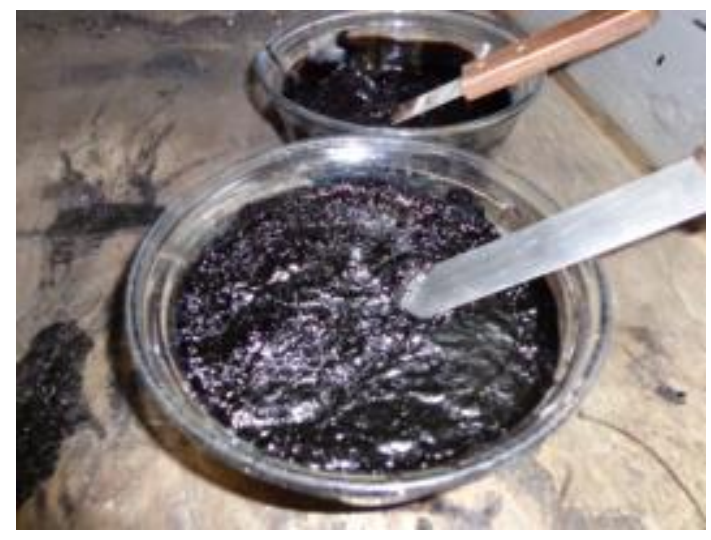

(a)

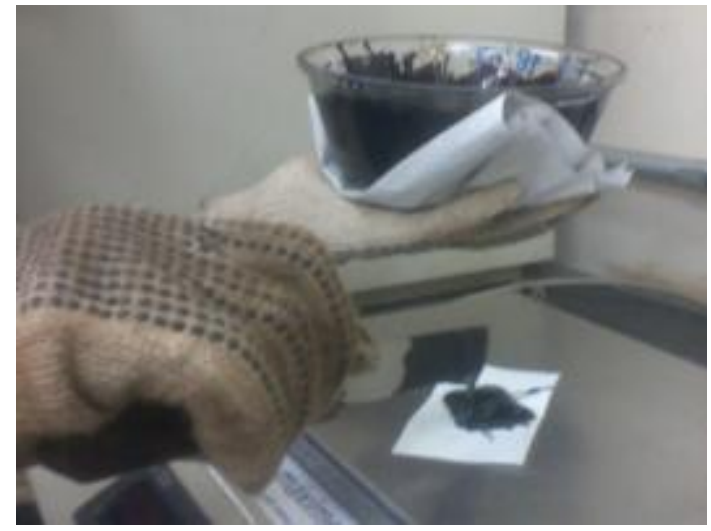

(c)

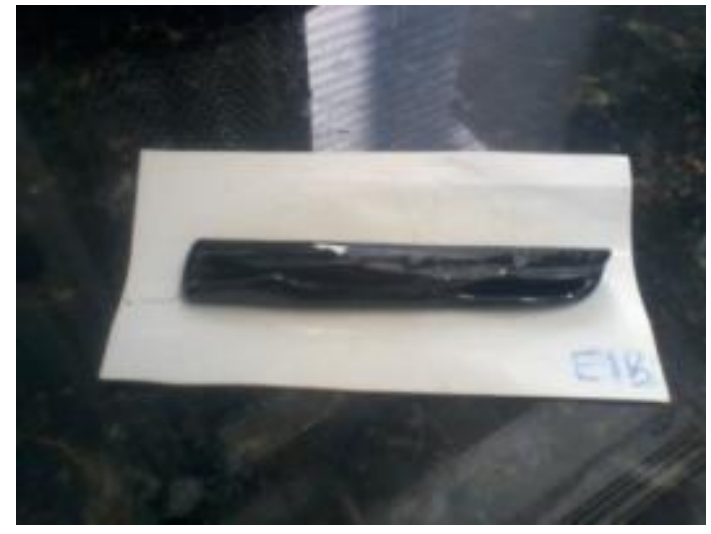

(e)

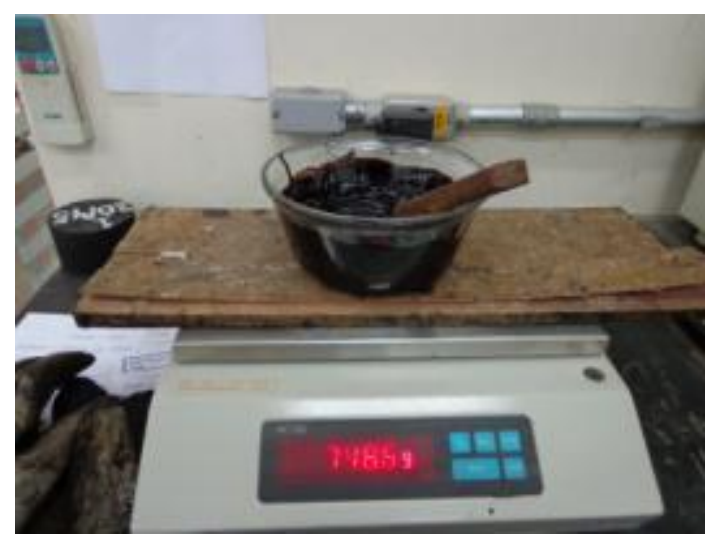

(b)

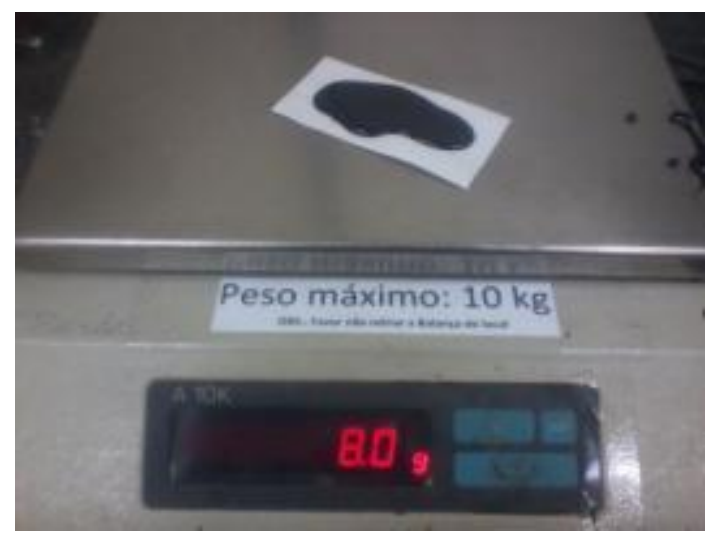

(d)

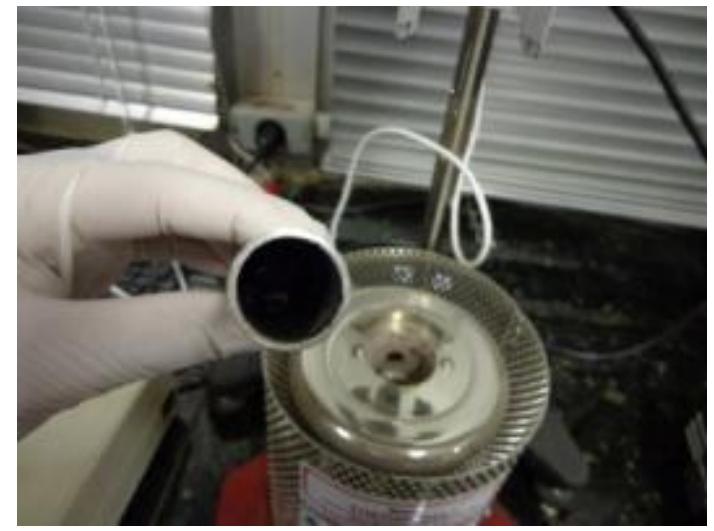

(f) 


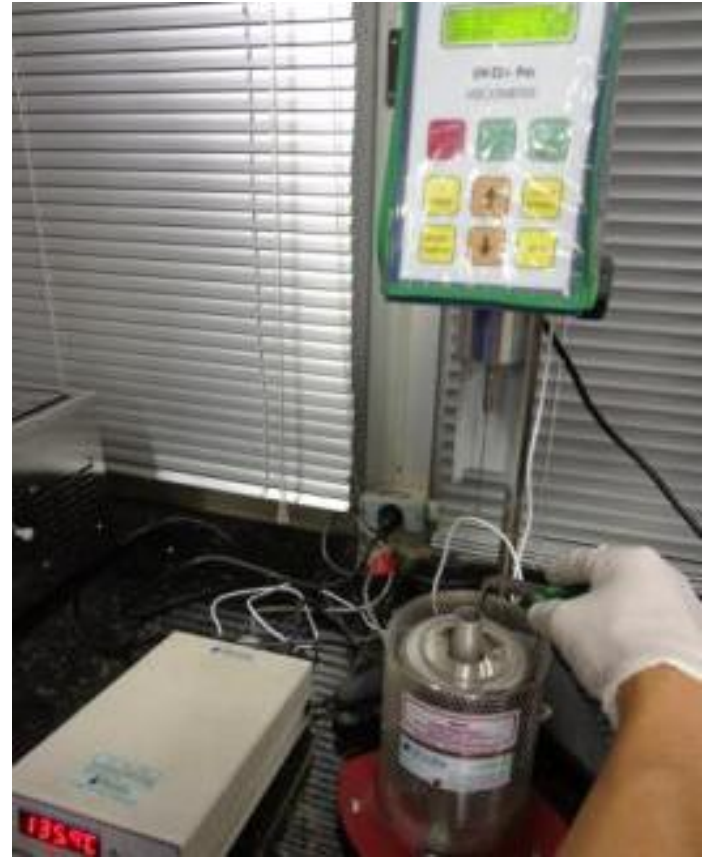

(g)

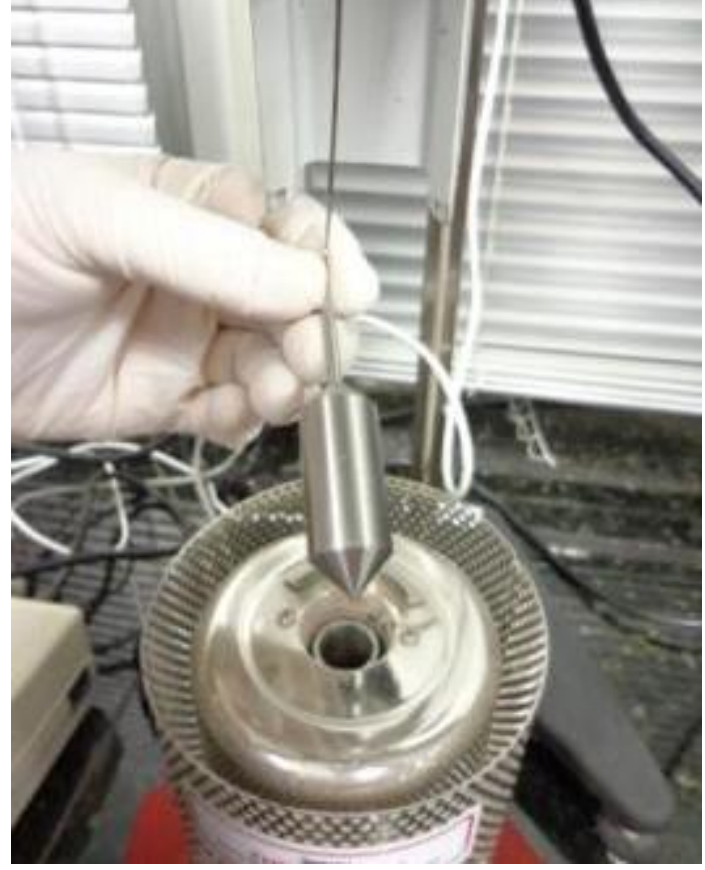

(h)

Figura 3.4 - Ensaio de resíduo por evaporação e viscosidade Brookfield (a) amostras na estufa para evaporação da água; (b) pesagem da massa de ligante residual para certificação da evaporação de toda a água (ensaio de resíduo); (c), (d), (e) e (f) preparação da amostra para o ensaio de viscosidade; (g) e (h) equipamento de ensaio (viscosidade Brookfield)

A Figura 3.5 mostra o resultado da viscosidade rotacional em função da temperatura. Percebe-se que as três emulsões diferem bastante no que diz respeito à viscosidade. $\mathrm{O}$ asfalto residual da Emulsão 2 apresentou valores bem superiores aos da Emulsão 1, principalmente nas temperaturas mais baixas de ensaio, enquanto o ligante residual da Emulsão 3, valores superiores a ambas.

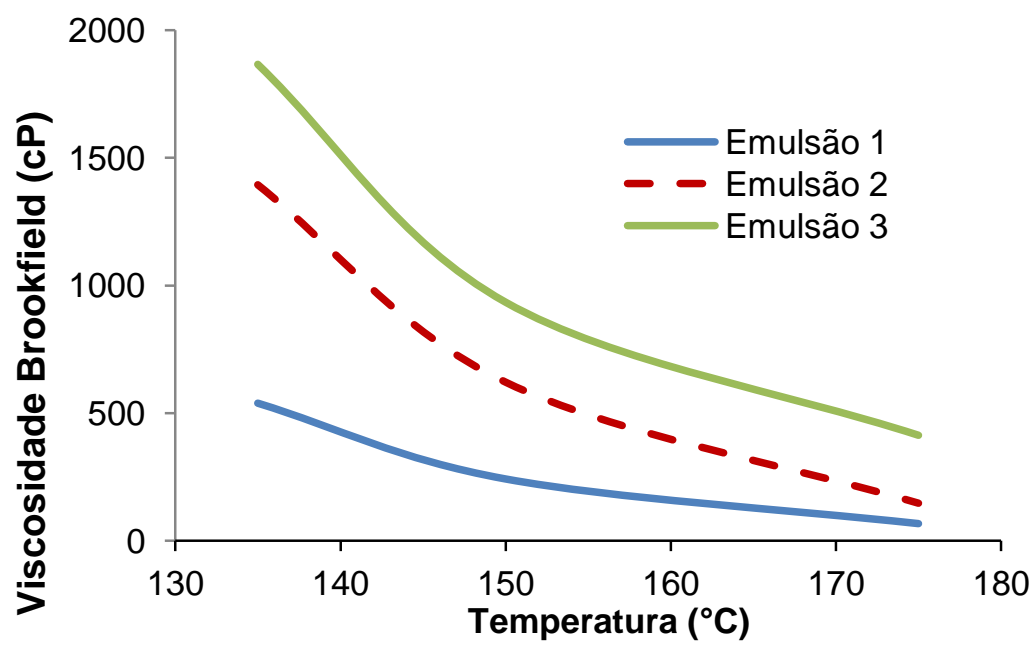

Figura 3.5 - Curvas de viscosidade versus temperatura para ensaio de viscosidade Brookfield nos resíduos das Emulsões 1 e 2 
Para melhor caracterizar os resíduos das duas emulsões asfálticas modificadas (Emulsão 2 e Emulsão 3), realizou-se ensaio de Recuperação Elástica (NBR15086:2006). O ensaio utiliza equipamento dutilômetro para alongar uma amostra de volume e formato conhecidos (Figura 3.6 (a)) até um comprimento de $200 \mathrm{~mm}$. O ensaio é feito à $25^{\circ} \mathrm{C}$ e velocidade de estiramento de $5 \mathrm{~cm} / \mathrm{min}$. Quando atingido o deslocamento de $200 \mathrm{~mm}$, o fio de ligante formado deve ser cortado e, após $60 \mathrm{~min}$, observa-se quanto da amostra retornou a sua posição inicial (Figura 3.6 (b)). As Emulsões 2 e 3 apresentaram retorno elástico de $68 \%$ e $76 \%$, respectivamente.

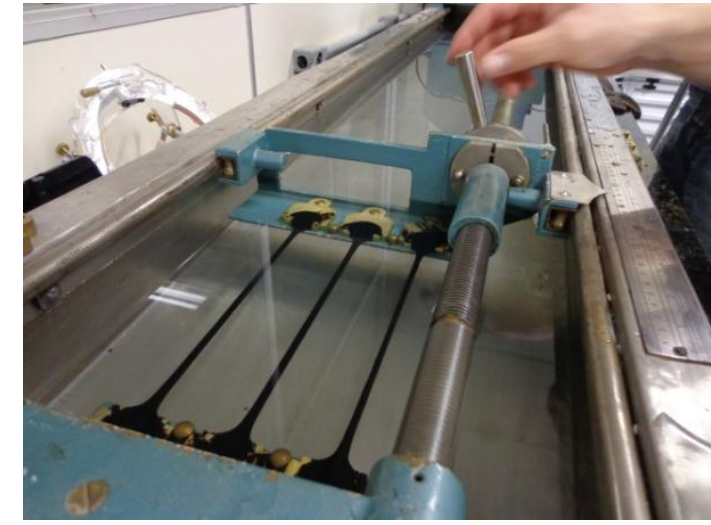

(a)

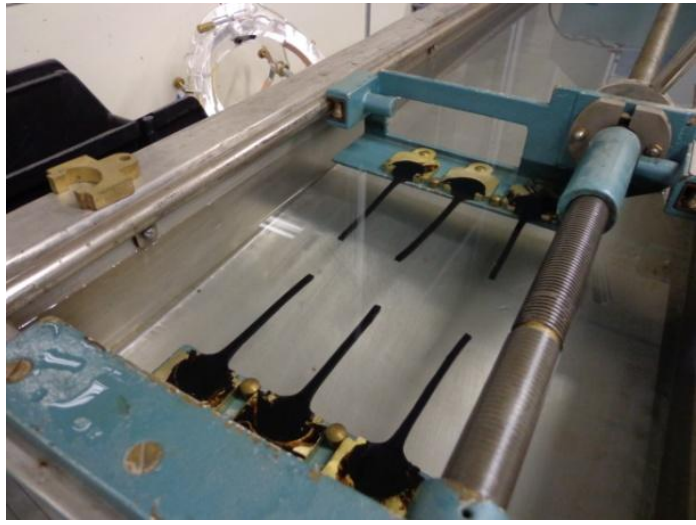

(b)

Figura 3.6 - Ensaio de recuperação elástica (a) alongamento das amostras; (b) amostras durante retorno elástico

\subsubsection{Geotêxtil e grelha}

O geotêxtil utilizado, RT-10 da marca BIDIM (Figura 3.7 (a)), possui as características descritas na Tabela 3.4, de acordo com o fabricante (ver especificações no Anexo D):

Tabela 3.4 - Propriedades principais do geotêxtil utilizado no trecho experimental

\begin{tabular}{ccc}
\hline Propriedades Mecânicas & $\begin{array}{c}\text { Direção } \\
\text { Principal }\end{array}$ & $\begin{array}{c}\text { Direção } \\
\text { Transversal }\end{array}$ \\
\hline Alongamento na ruptura $(\%)$ & 60 & 70 \\
Força de Tração máxima $(\mathrm{kN} / \mathrm{m})$ & 10 & 9 \\
\hline
\end{tabular}

A grelha de fibra de vidro, Glasphalt G, produzida pela S\&P Reinforcement (Figura 3.7 (b)), já vem impregnada com material asfáltico e possui as características descritas na Tabela 3.5, também fornecidas pelo fabricante (ver especificações no Anexo E): 
Tabela 3.5 - Propriedades principais da grelha de fibra de vidro utilizada no trecho experimental

\begin{tabular}{ccc}
\hline Propriedades Mecânicas & $\begin{array}{c}\text { Direção } \\
\text { Principal }\end{array}$ & $\begin{array}{c}\text { Direção } \\
\text { Transversal }\end{array}$ \\
\hline Resistência à Tração $\left(\mathrm{kN} / \mathrm{mm}^{2}\right)$ & 73 & 73 \\
Alongamento na ruptura $(\%)$ & $3,5-4,5$ & $3,5-4,5$ \\
Força de Tração máxima $(\mathrm{kN} / \mathrm{m})$ & $111(2,7 \%)$ & $111(2,7 \%)$ \\
\hline
\end{tabular}

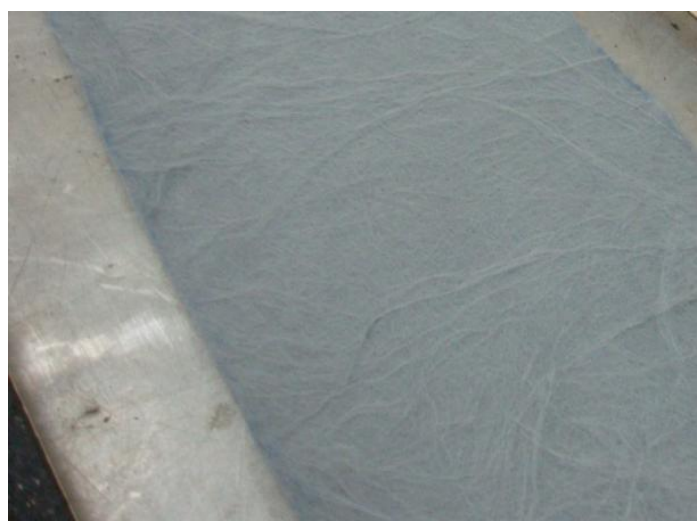

(a)

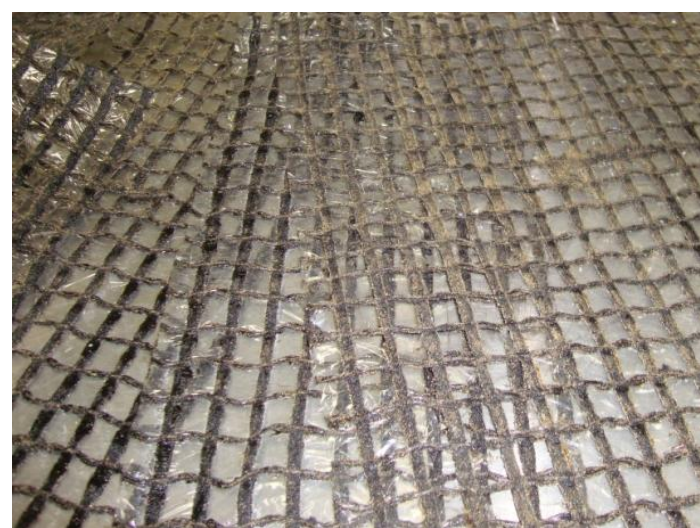

(b)

Figura 3.7 - (a) Geotêxtil e (b) Grelha de fibra de vidro, ambos utilizados para confecção das amostras em laboratório

\subsection{PREPARAÇÃO DAS PLACAS}

O sistema de dupla camada (SAMI+CBUQ) foi preparado em placas de $18,0 \mathrm{x}$ $50,0 \mathrm{~cm}$, com espessura total de 7,0 $\mathrm{cm}(2,0 \mathrm{~cm}$ de $\mathrm{SAMl}+5,0 \mathrm{~cm}$ de CBUQ), conforme ilustrado na Figura 3.8.

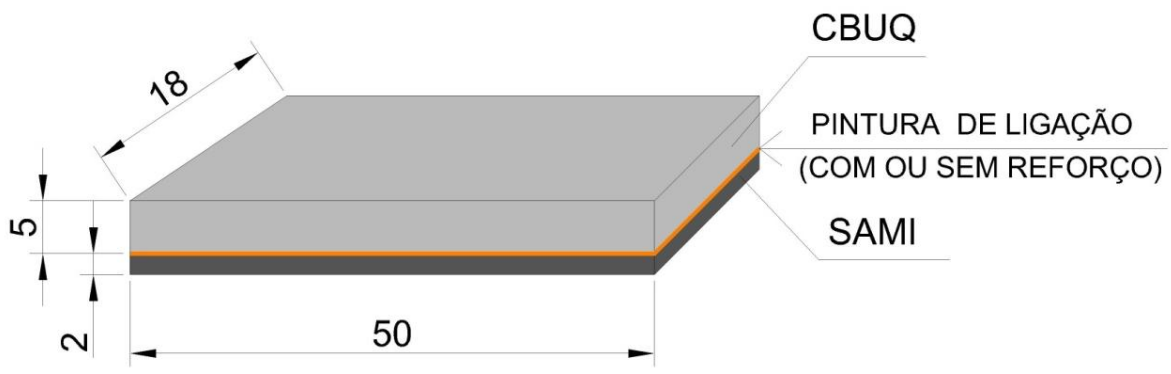

Figura 3.8 - Sistema de dupla camada (SAMI+CBUQ)

Os moldes disponíveis para preparação das placas através da mesa compactadora do LCPC (Laboratoire Central dês Ponts et Chaussées) têm 5,0 cm ou 10,0 cm de altura. Dessa forma, para atingir a espessura de 2,0 cm na camada de SAMI, foi necessário o uso de duas placas de madeira com $1,5 \mathrm{~cm}$ de espessura 
cada, conforme Figura 3.9, utilizando o molde de 5,0 cm. Analogamente, para compactação da camada de CBUQ com 5,0 cm sobre a camada de SAMI de 2,0 cm, as mesmas duas placas de madeira foram utilizadas para atingir a espessura total de $10,0 \mathrm{~cm}$ do molde.

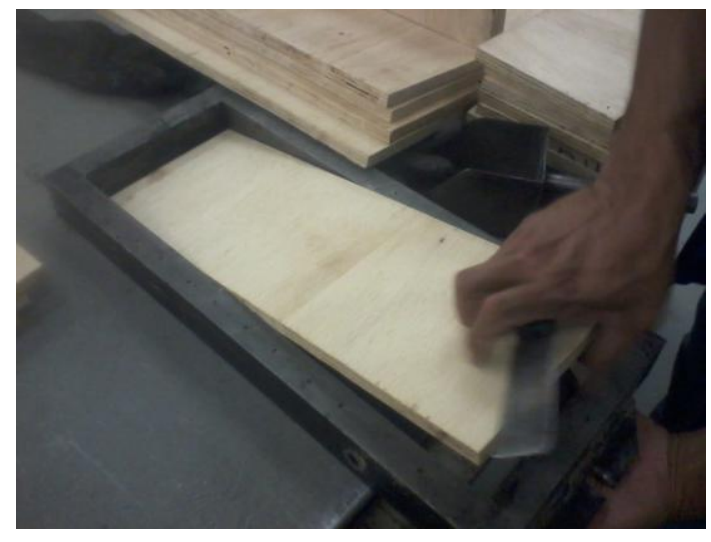

(a)

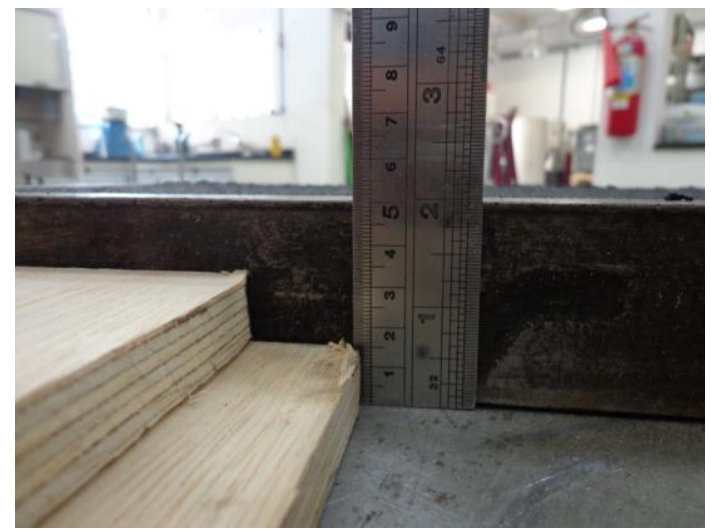

(b)

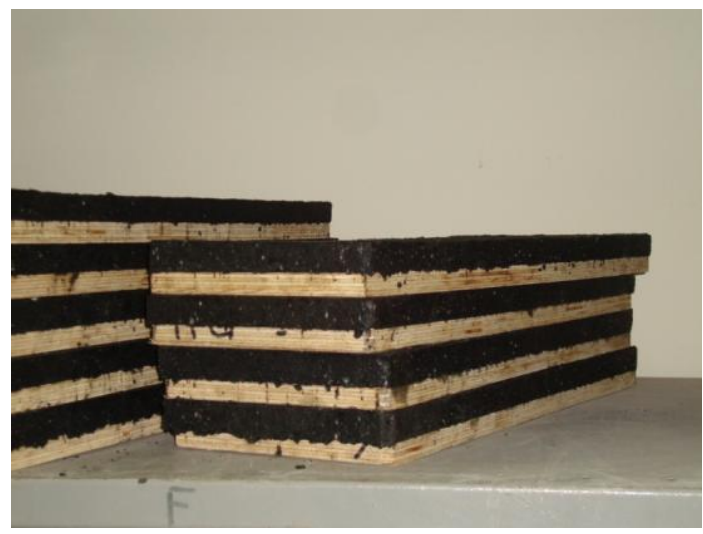

(c)

Figura 3.9 - (a) e (b) Molde de $5 \mathrm{~cm}$ e utilização de placas de madeira $(2 \times 1,5 \mathrm{~cm})$ para compactação da (c) camada de SAMI $(e=2,0 \mathrm{~cm})$.

Para garantir a espessura correta durante a compactação, a massa das misturas foi estabelecida pelo volume a ser preenchido no molde, em função da densidade aparente de cada mistura (informações retiradas do projeto fornecido pela usina). A pesagem da quantidade a ser utilizada em cada placa foi feita em laboratório (Figura 3.10). 


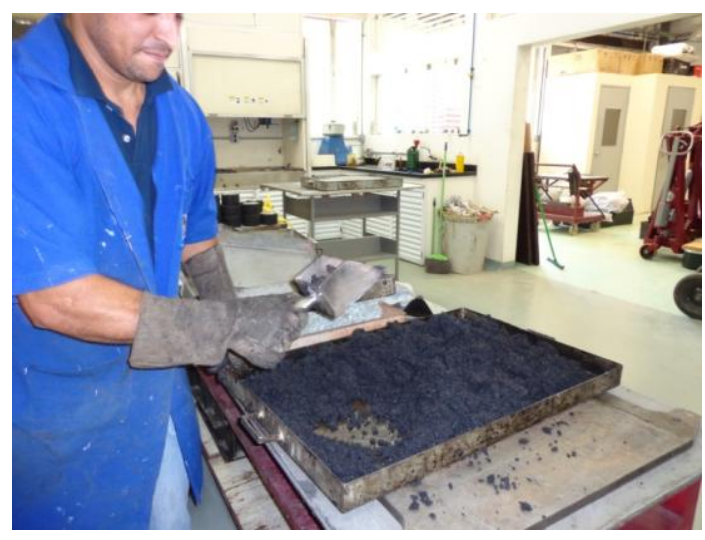

(a)

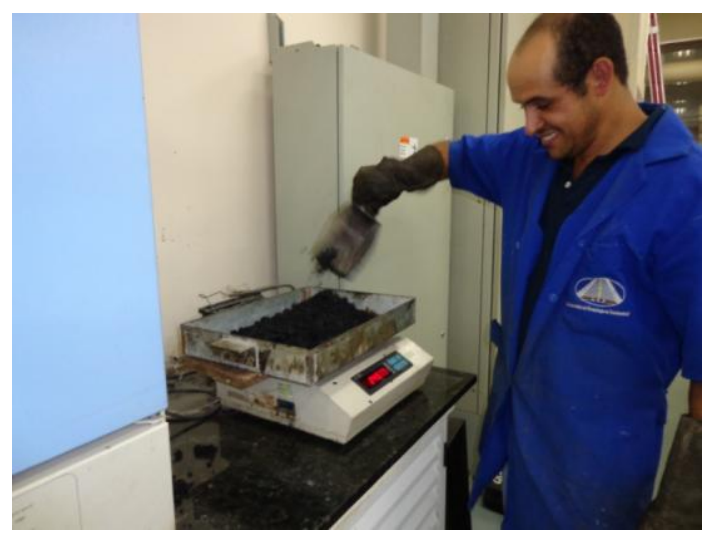

(b)

Figura 3.10 - Pesagem das misturas para compactação com espessuras de 2,0 cm (SAMI) e 5,0 cm (CBUQ)

A mistura foi mantida em estufa a $50^{\circ} \mathrm{C}$ por aproximadamente três horas antes da pesagem, de modo a facilitar sua remoção das latas de armazenamento. Após pesagem, os recipientes contendo as misturas foram deixados em estufa a $150^{\circ} \mathrm{C}$ (Figura 3.11) para garantir que a temperatura de compactação estivesse entre 140 e $150^{\circ} \mathrm{C}$.

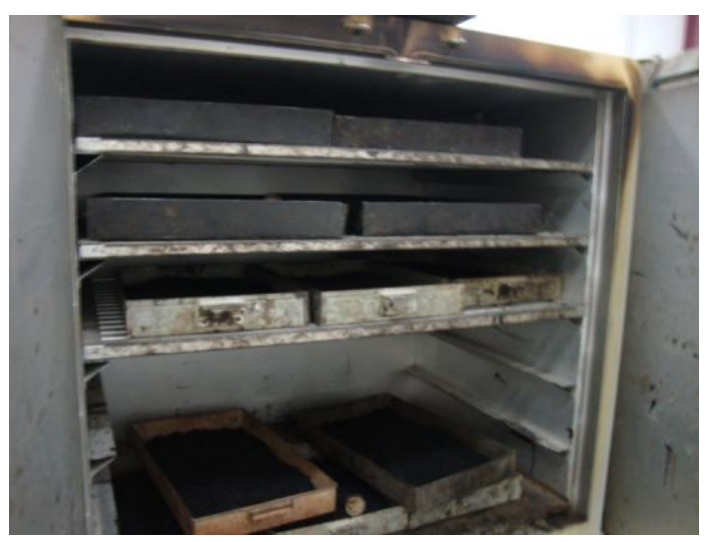

Figura 3.11 - Misturas em estufa para garantir temperatura de compactação $\left(140^{\circ} \mathrm{C}\right.$ a $\left.150^{\circ} \mathrm{C}\right)$

A produção das placas seguiu as etapas descritas a seguir:

a) Compactação da camada de SAMI com $2 \mathrm{~cm}$ de espessura no compactador francês LCPC (Figura 3.12 (a) a (f)); 


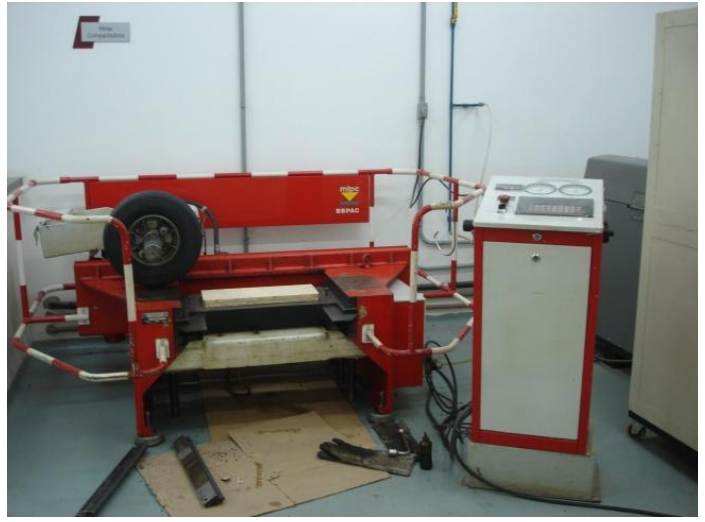

(a)

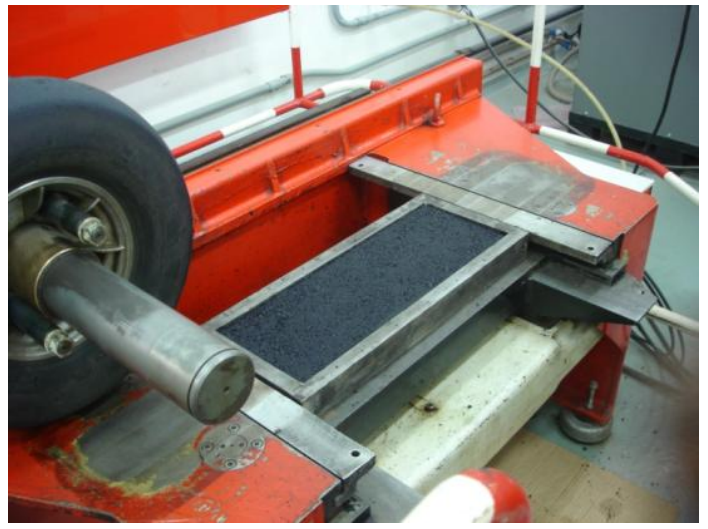

(c)

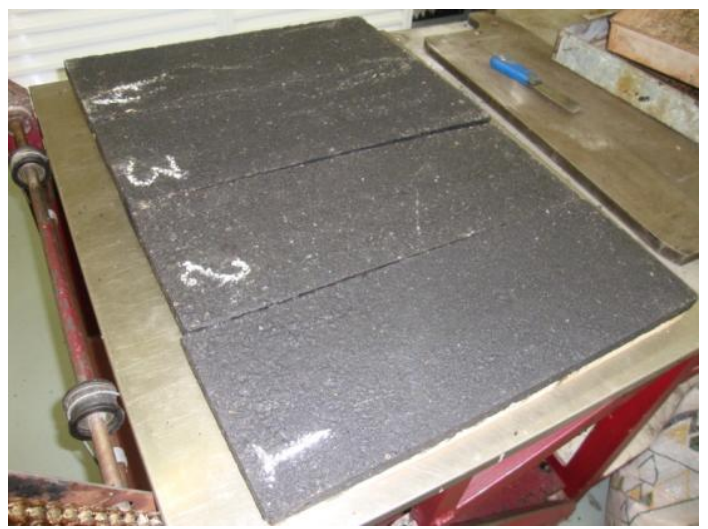

(e)

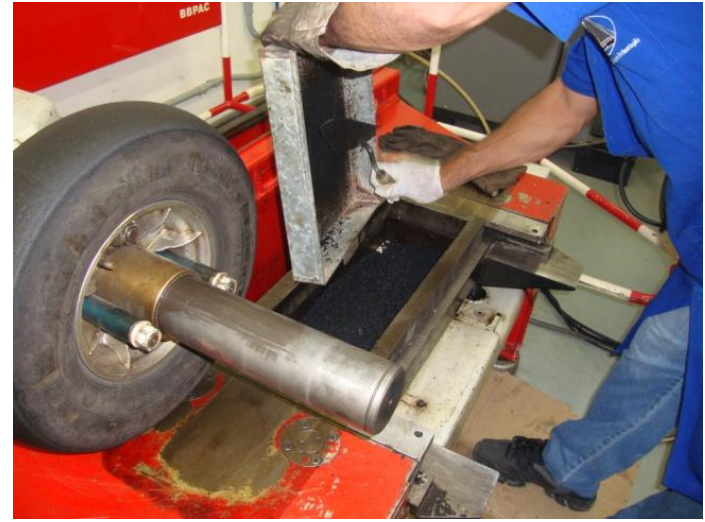

(b)

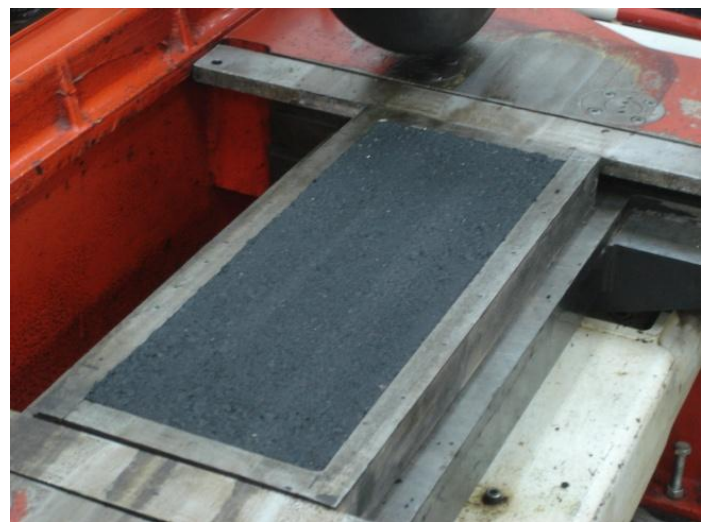

(d)

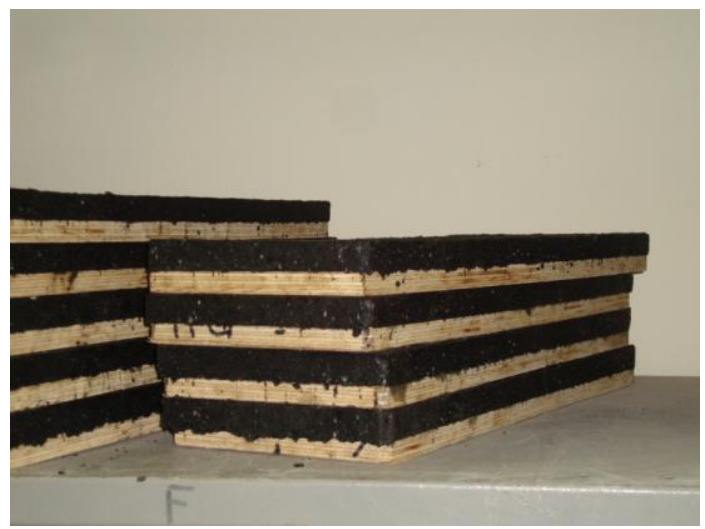

(f)

Figura 3.12 - Compactação da camada de SAMI (a) mesa compactadora LCPC; (b) colocação da mistura de SAMI (140ㄷ); (c) e (d) compactação; (e) e (f) camadas de SAMI finalizadas

b) Preparação da interface com aplicação da pintura de ligação de diferentes tipos e taxas de emulsão (Figura 3.13 (a) a (d)). A emulsão foi aplicada sem recortes e a taxa medida foi de emulsão e não de asfalto residual; 


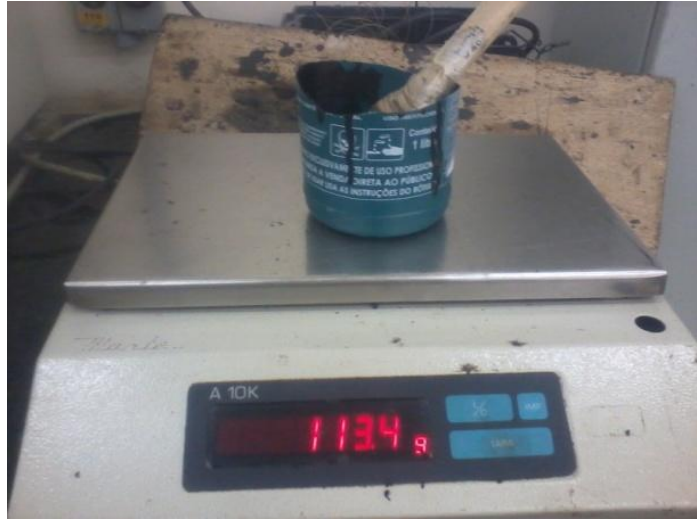

(a)

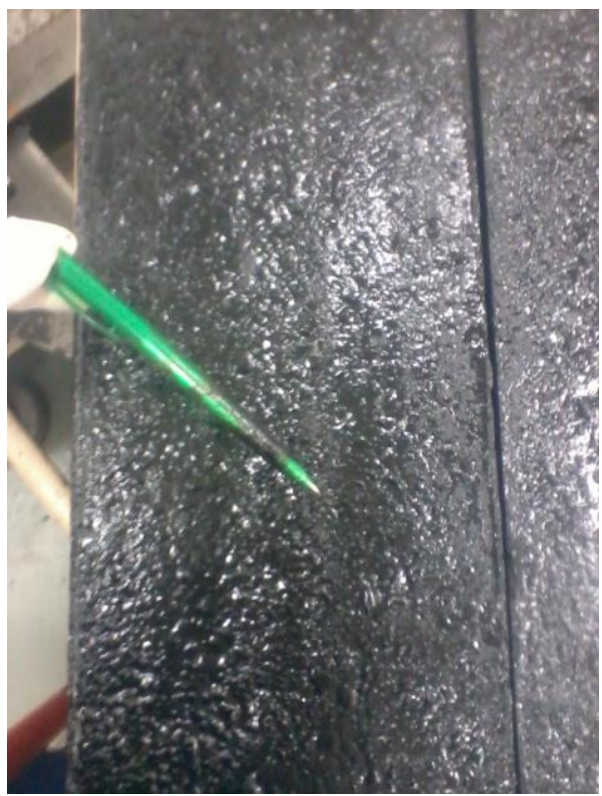

(c)

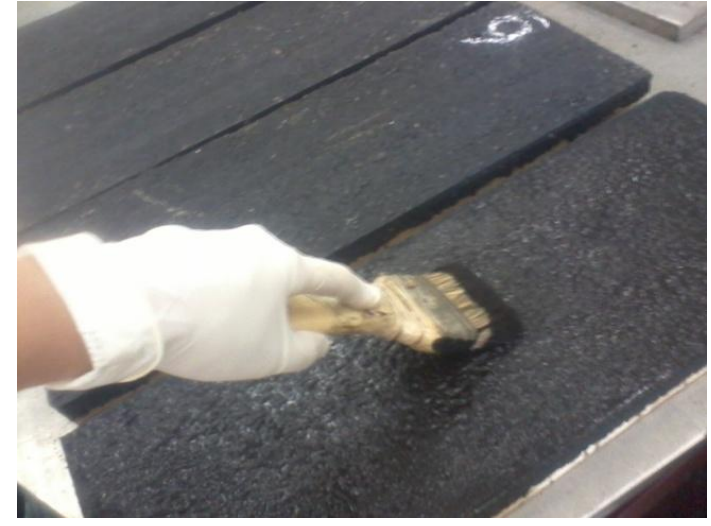

(b)

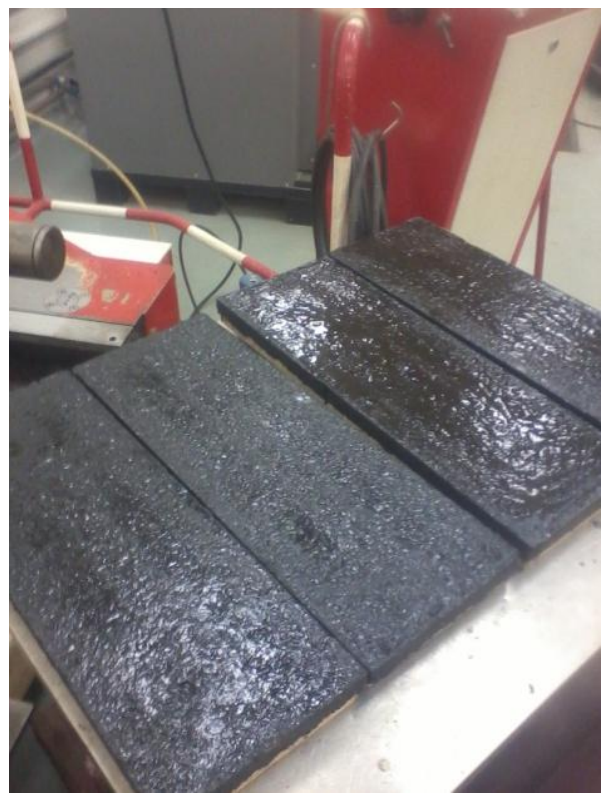

(d)

Figura 3.13 - Aplicação de pintura de ligação na interface SAMI-CBUQ (a) controle da taxa de emulsão por pesagem sequencial do conjunto recipiente+pincel+emulsão antes e após aplicação; (b) aplicação de pintura de ligação com pincel; (c) e (d) emulsão após aplicação a espera da ruptura

c) Aplicação de geotêxtil (Figura 3.14 (a) a (d)), e grelha de fibra de vidro (Figura 3.15 (a) e (b)) sobre a primeira camada asfáltica, após ruptura da emulsão; 


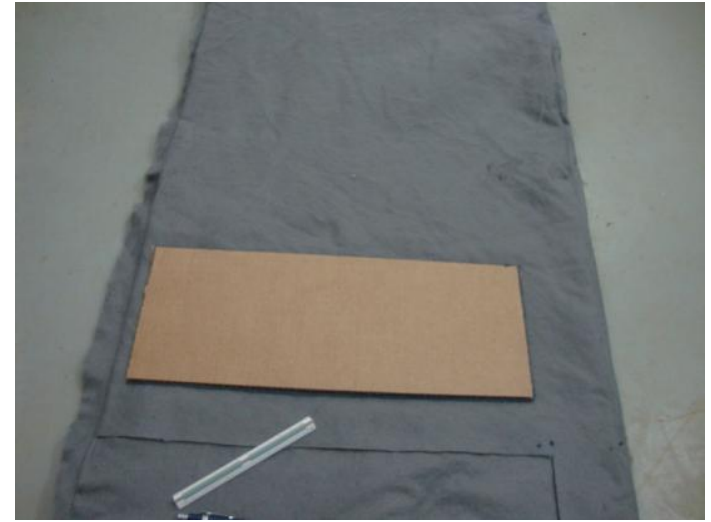

(a)

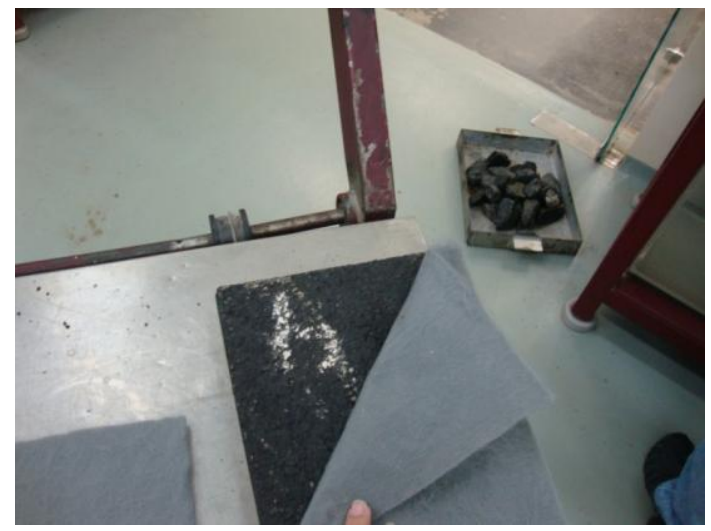

(c)

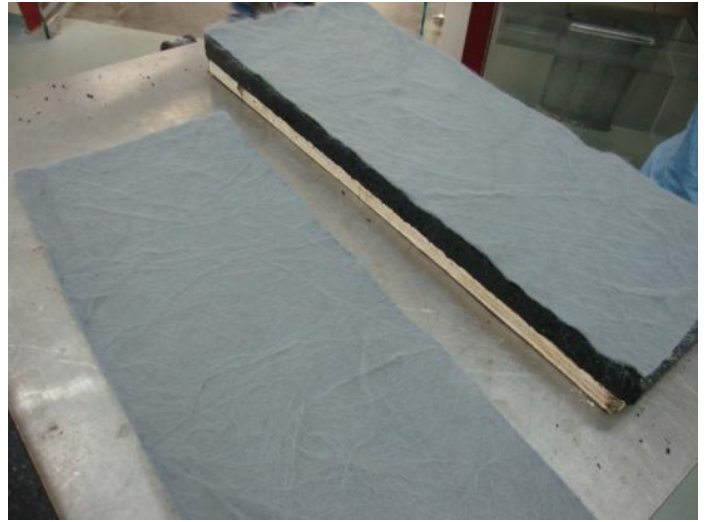

(b)

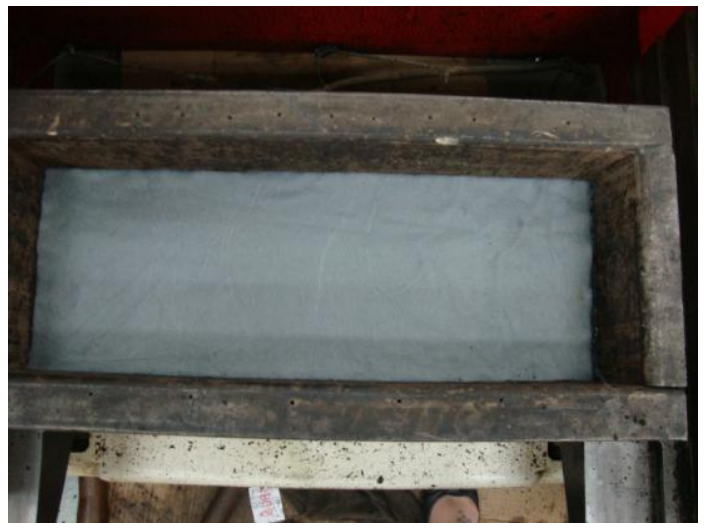

(d)

Figura 3.14 - Preparo da interface das placas com reforço de geotêxtil: (a) e (b) recorte de retângulos da manta geotêxtil nas dimensões da placa $(18 \times 50 \mathrm{~cm})$; (c) e (d) manta de geotêxtil sobre a placa de SAMI antes da compactação da camada de CBUQ (placa P4, taxa de emulsão $\left.0,0 \mathrm{~L} / \mathrm{m}^{2}\right)$

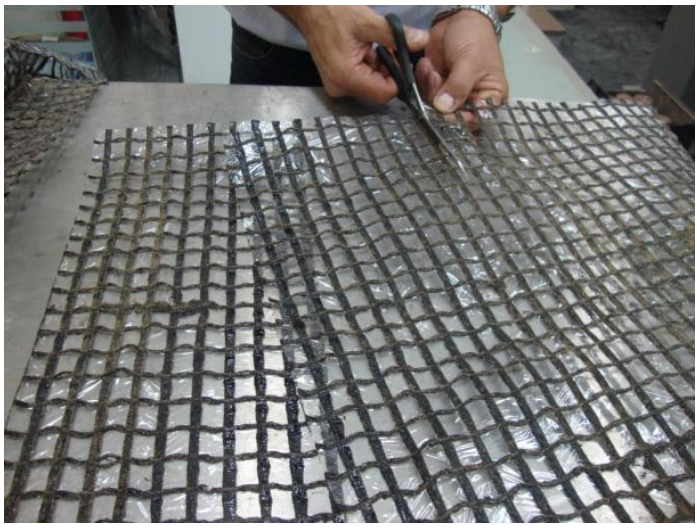

(a)

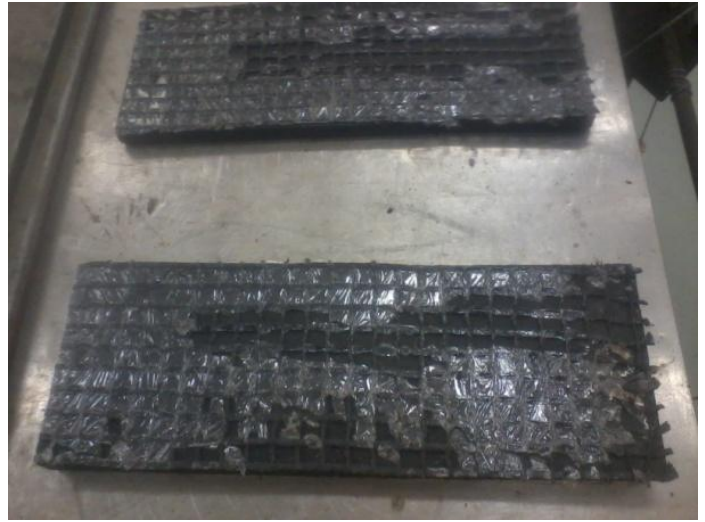

(b)

Figura 3.15 - Preparo da interface das placas com reforço de grelha de fibra de vidro (a) recorte de retângulos da grelha de fibra de vidro nas dimensões da placa $(18 \times 50 \mathrm{~cm})(\mathrm{b})$ grelha aplicada sobre a placa de SAMI antes da compactação da camada de CBUQ

d) Aplicação de nova camada de pintura de ligação nas placas com geotêxtil (Figura 3.16). O valor total da taxa de pintura de ligação nas 
placas com geotêxtil foi dividido igualmente em duas aplicações: antes e após a colocação do material sintético.

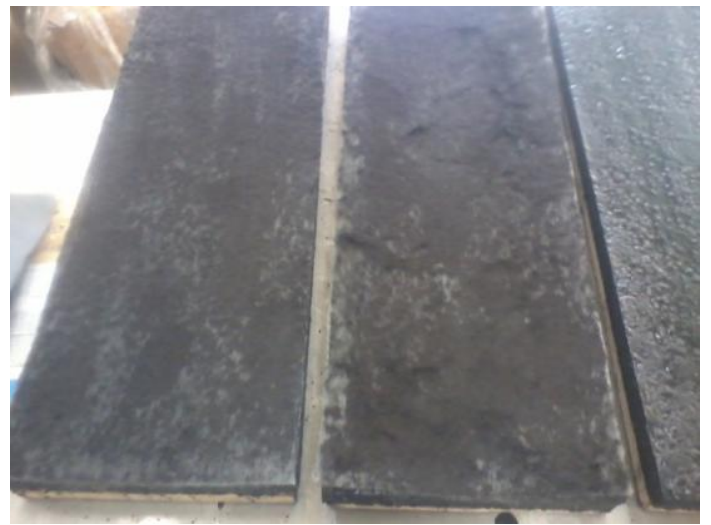

Figura 3.16 - Aplicação de emulsão após colocação da manta geotêxtil

e) Utilização de maçarico manual para queima do filme plástico protetor da grelha (Figura 3.17 (a) e (b)), etapa recomendada pelo fabricante para execução em campo;

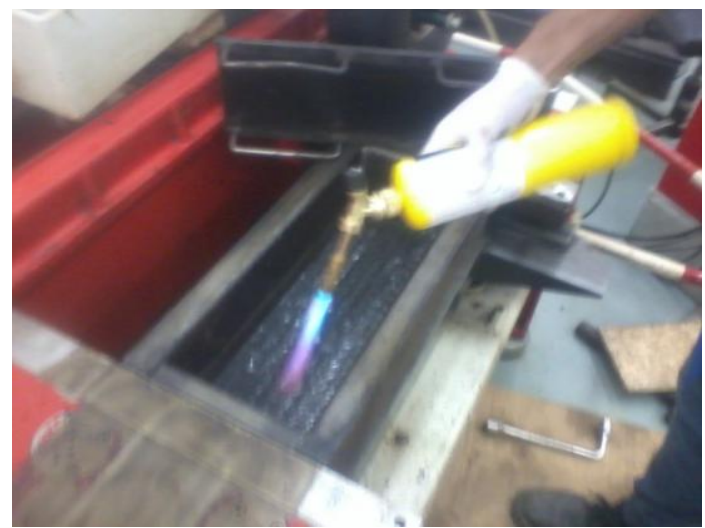

(a)

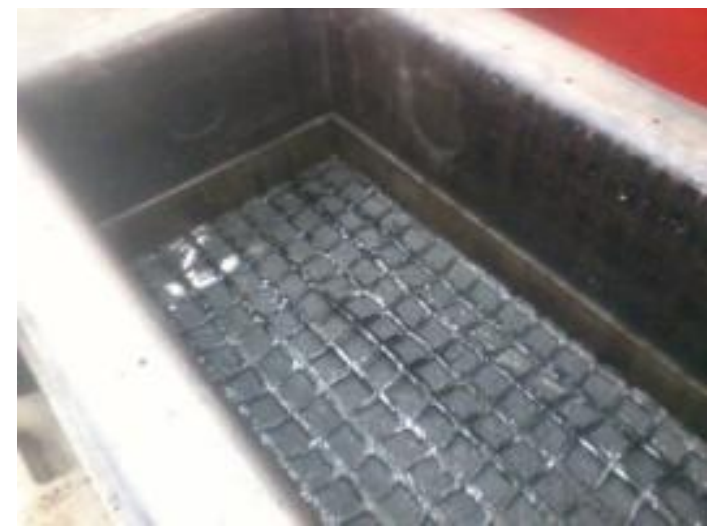

(b)

Figura 3.17 - Aplicação de grelha de fibra de vidro (a) queima do filme plástico protetor da grelha; (b) grelha a espera da compactação da camada de CBUQ

f) Por fim, compactação da camada de CBUQ com $5 \mathrm{~cm}$ de espessura, também na mesa compactadora LCPC (Figura 3.18 (a) e (b)). O CBUQ foi moldado sobre a superfície da primeira camada asfáltica preparada, com o tratamento determinado caso a caso, e após ruptura completa da emulsão. 


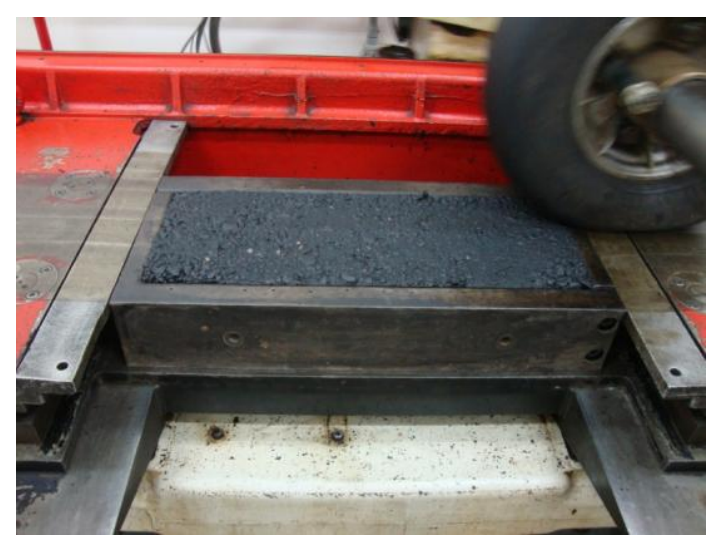

(a)

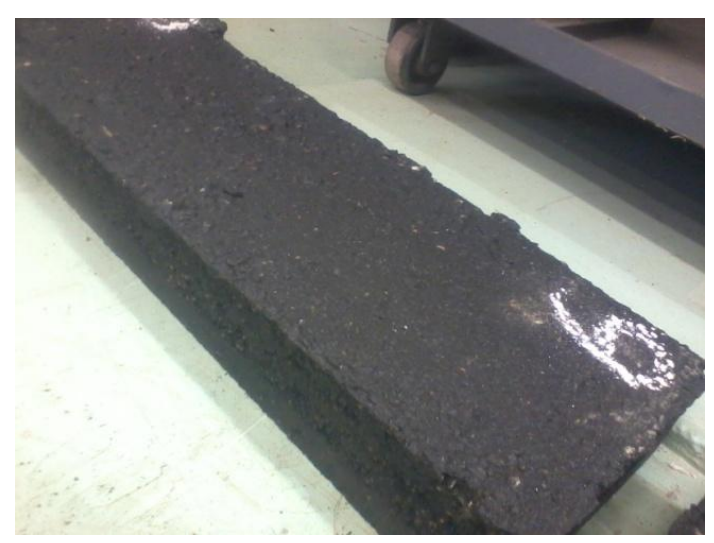

(b)

Figura 3.18 - (a) Compactação da camada de CBUQ na mesa compactadora LCPC; (b) placa com dupla camada (SAMI+CBUQ) pronta

O sistema CBUQ+CBUQ foi preparado com as mesmas dimensões de $18,0 \mathrm{x}$ $50,0 \mathrm{~cm}$, mas espessura total de $10,0 \mathrm{~cm}(5,0 \mathrm{~cm}$ da primeira camada de CBUQ + $5,0 \mathrm{~cm}$ da segunda camada), conforme ilustrado na Figura 3.19. Por esse motivo, não houve necessidade de utilização de placas de madeira para adequação aos moldes de 5,0 e 10,0 cm da mesa compactadora.

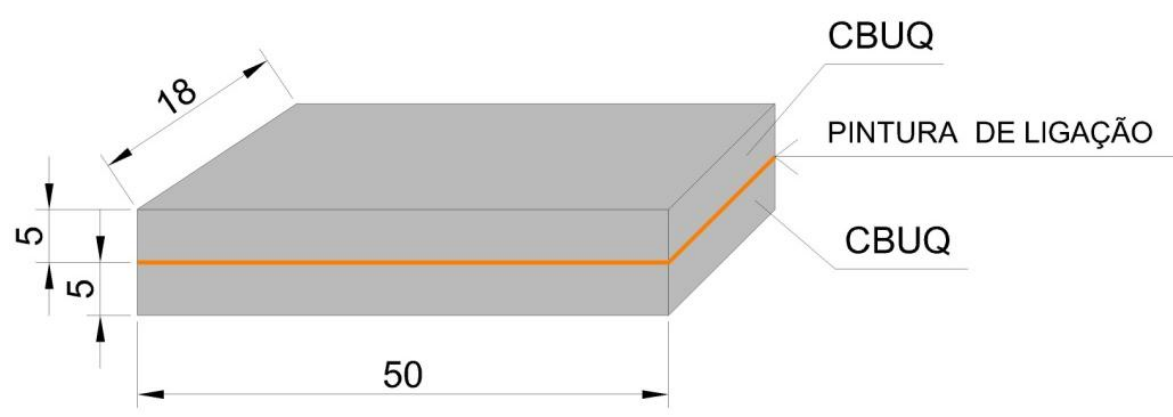

Figura 3.19 - Sistema de dupla camada (CBUQ+CBUQ)

As placas $C B U Q+C B U Q$ foram produzidas a fim de analisar a influência do tipo de superfície de contato na aderência entre camadas. Desta forma, não houve, neste caso, variação do tipo de emulsão ou inserção de geotêxtil e grelha.

\subsection{TEXTURA DAS MISTURAS}

A resistência ao cisalhamento entre duas camadas asfálticas é também função do travamento mecânico existente entre elas, além da presença ou não de materiais na interface, e da taxa ou do tipo de emulsão adotada como pintura de ligação. As 
misturas de SAMI e CBUQ apresentam, visualmente, texturas superficiais distintas, conforme observado na Figura 3.20.

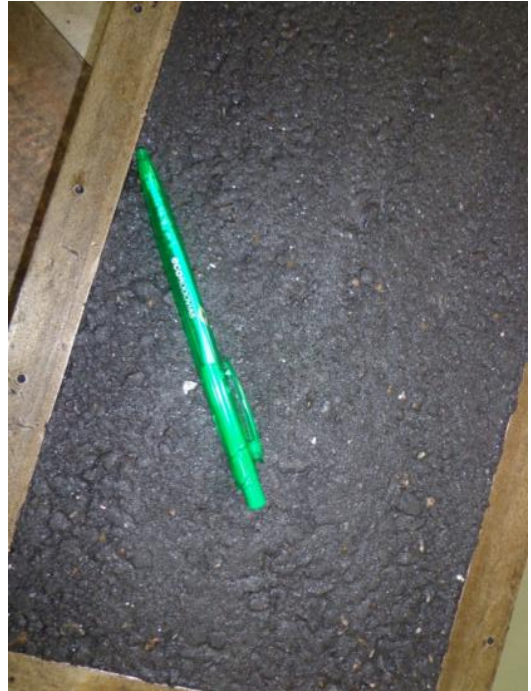

(a)

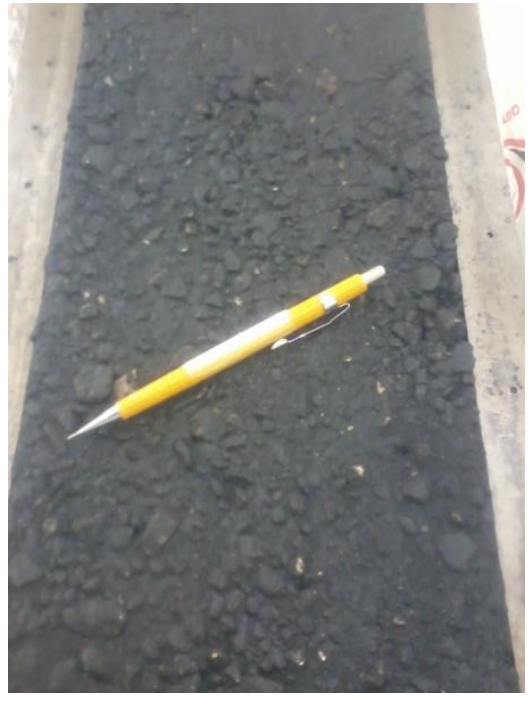

(b)

Figura 3.20 - Textura das misturas de SAMI e CBUQ (a) placa de SAMI após compactação; (b) placa de CBUQ após compactação

A macrotextura das superfícies foi mensurada por meio de ensaios de Mancha de Areia, segundo norma ASTM D965 (2001). O procedimento de ensaio consiste em: (i) limpar previamente a superfície; (ii) aplicar certa quantidade de esferas de vidro arredondadas e de graduação uniforme (cerca de $25.000 \mathrm{~mm}^{3}$ ), passantes na peneira $N^{\circ} 60(0,177 \mathrm{~mm})$ e retidas na $N^{\circ} 80(0,250 \mathrm{~mm})$ sobre a superfície; (iii) promover com um disco movimentos circulares formando um círculo de areia; (iv) anotar quatro medidas do diâmetro da "mancha" em diferentes direções. Com o diâmetro médio $(\mathrm{Dm})$, pode-se determinar a altura média da mancha de areia $(\mathrm{Hm})$ através da equação:

$$
H m=\frac{4 V}{(D m)^{2} \pi}
$$

Onde:

$\mathrm{Hm}$ - altura média de mancha de areia, em mm;

$V$ - volume constante de areia de $25.000 \mathrm{~mm}^{3}$;

$D m$ - diâmetro médio do círculo de areia, em $\mathrm{mm}$;

Devido às dimensões reduzidas das placas produzidas em laboratório $(18,0 \mathrm{~cm}$ de largura), optou-se por utilizar a metade do volume de areia estabelecido na 
norma acima citada, ou seja, $12.500 \mathrm{~mm}^{3}$. Os resultados do ensaio de mancha de areia obtidos para a superfície de SAMI e de CBUQ seguem na Tabela 3.6.

Tabela 3.6 - Macrotextura das superfícies de SAMI e CBUQ, por meio do ensaio de mancha de areia

\begin{tabular}{cccc}
\hline Mistura & № ensaios & HS médio & Desvio padrão \\
\hline SAMI & 9 & 0,66 & 0,06 \\
\hline CBUQ & 9 & 0,89 & 0,10 \\
\hline
\end{tabular}

Recomenda-se que a altura média de mancha de areia esteja entre 0,6 $\mathrm{mm}$ e 1,2 mm (DNIT, 2006). Abaixo de 0,6 mm, a macrotextura apresenta uma tendência a ser fina e aumenta o risco de hidroplanagem. Acima de 1,2 $\mathrm{mm}$, a macrotextura apresenta uma característica grosseira promovendo um desgaste excessivo de pneus e, em geral, o aumento do ruído ao rolamento, a depender do tipo de revestimento asfáltico. Ambas as superfícies avaliadas estão dentro do limite estabelecidos na especificação do DNIT, porém é possível observar a diferença de textura obtida entre elas, sendo o CBUQ mais rugoso que o SAMI.

\subsection{ENSAIO LEUTNER PARA MEDIDA DA ADERÊNCIA ENTRE CAMADAS}

A aderência entre as camadas foi avaliada pela medida da resistência ao cisalhamento direto na interface das camadas de CBUQ e SAMI ou CBUQ e CBUQ, em cada um dos corpos de prova. De cada placa produzida em laboratório, foram extraídos, com broca mecânica, dois corpos de prova cilíndricos de $150 \mathrm{~mm}$ de diâmetro. Nas placas com solução de somente pintura de ligação extraiu-se ainda um terceiro corpo de prova de $100 \mathrm{~mm}$ no centro (Figura 3.21 (a)) para avaliar a influência do tamanho da amostra nos resultados do ensaio. Após a extração, as amostras foram mantidas sobre tela metálica para secagem completa antes do início dos ensaios (Figura 3.21 (b)). Para analisar a influência do posicionamento dos corpos de prova ao longo da placa nos resultados de aderência, foram produzidas placas complementares (Emulsão 1 à taxa de $0,25 \mathrm{~L} / \mathrm{m}^{2}$ ) com extração de duas amostras de $100 \mathrm{~mm}$ de diâmetro nas laterais e uma amostra de $150 \mathrm{~mm}$ no centro. 


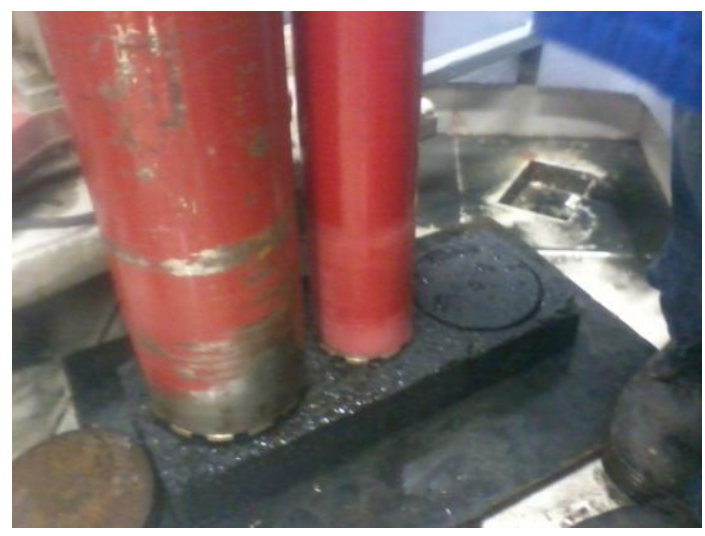

(a)

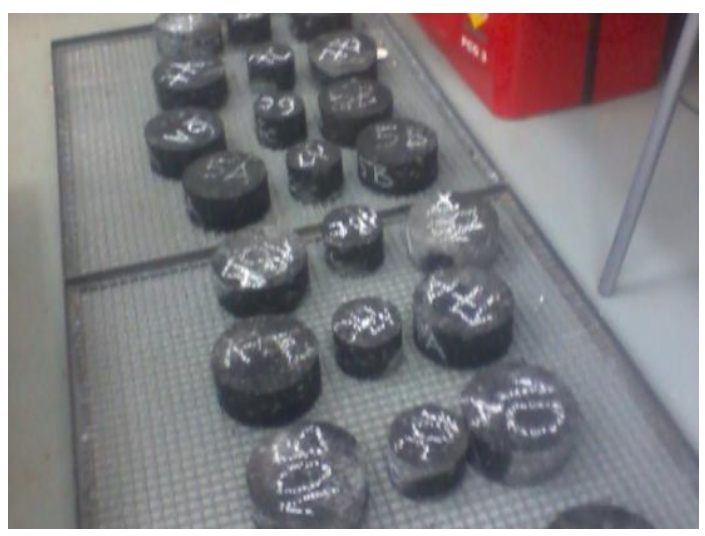

(b)

Figura 3.21 - (a) Extração de corpos de prova cilíndricos (150 e 100 mm de diâmetro) nas placas somente com pintura de ligação na interface; (b) CPs extraídos, aguardando secagem

Os CPs foram mantidos em câmara fria, a 20드. por pelo menos 12 horas antes do início do ensaio de cisalhamento. Aplicou-se carregamento monotônico à velocidade de deslocamento da prensa hidráulica MTS (Material Test System) constante e igual a $50 \mathrm{~mm} / \mathrm{min}$, conforme especificação alemã. A fim de avaliar a influência da velocidade de ensaio na aderência entre camadas, principalmente com o uso de emulsões modificadas, o ensaio também foi realizado com velocidade de 1 $\mathrm{mm} / \mathrm{min}$, para taxa de $0,25 \mathrm{~L} / \mathrm{m}^{2}$ em amostras somente com pintura de ligação na interface. Somente nestes casos, houve necessidade de utilização de câmara térmica para garantir que a temperatura de $20^{\circ} \mathrm{C}$ não variasse durante o ensaio. As Figuras 3.22 a 3.24 mostram algumas amostras em laboratório e a sequência de execução do ensaio de cisalhamento direto.

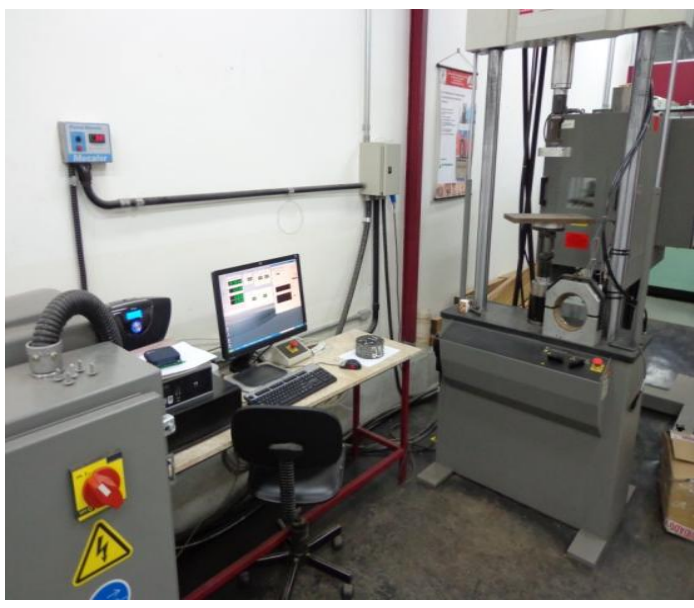

(a)

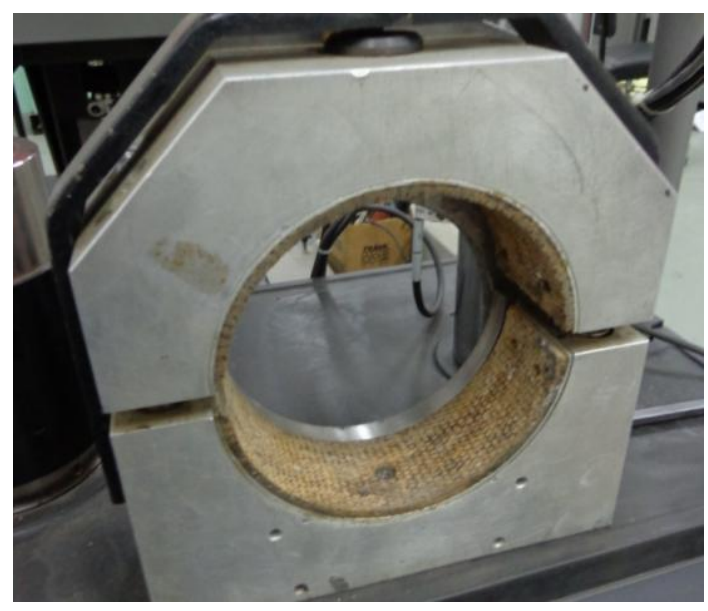

(b)

Figura 3.22 - (a) MTS e (b) aparato para realização do ensaio de cisalhamento Leutner 


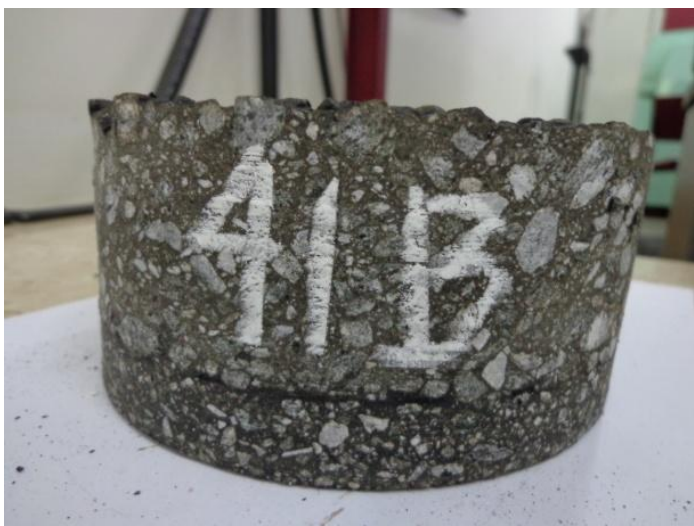

(a)

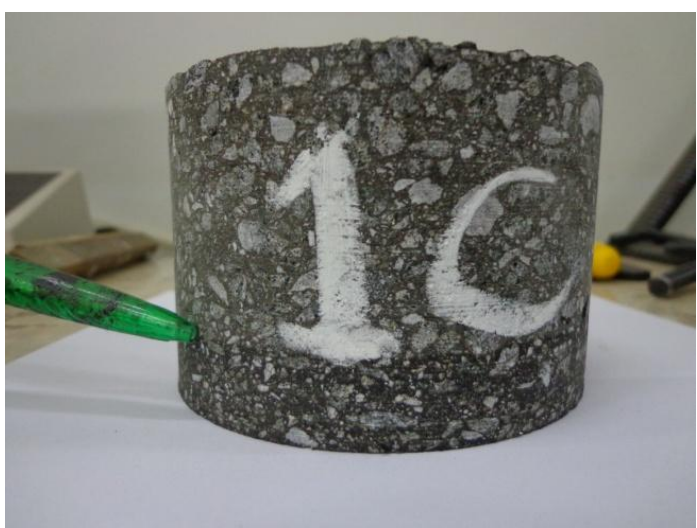

(c)

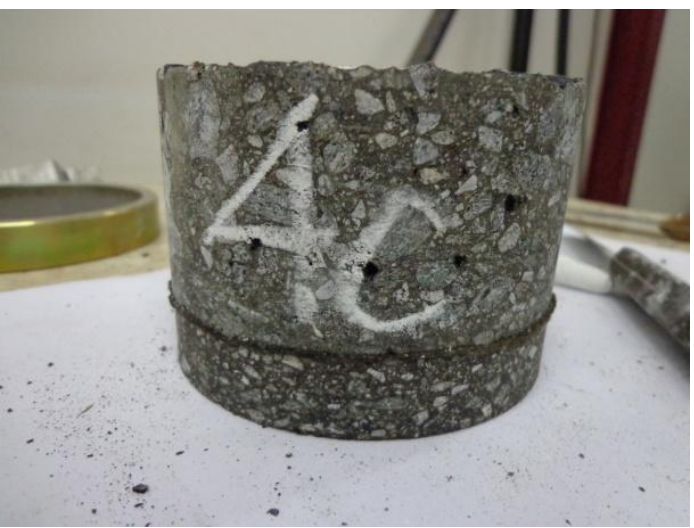

(b)

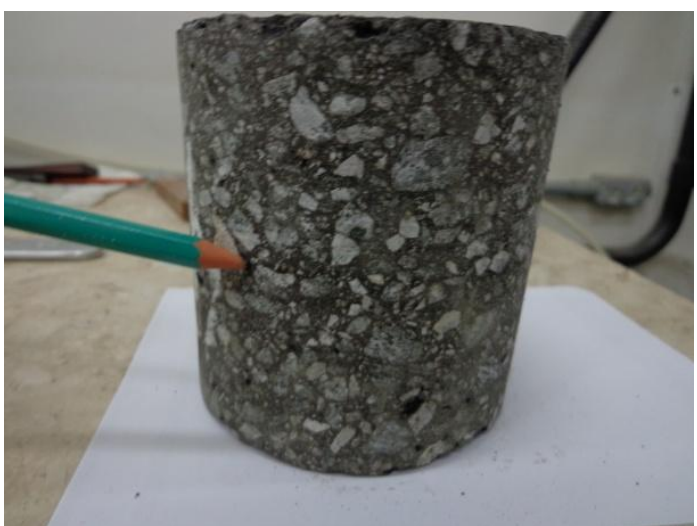

(d)

Figura 3.23 - Corpos de prova antes do ensaio de cisalhamento (a) exemplo de CP (SAMICBUQ) com $150 \mathrm{~mm}$ de diâmetro e grelha na interface; (b) exemplo de CP (SAMI-CBUQ) com $100 \mathrm{~mm}$ de diâmetro e geotêxtil na interface; (c) CP (SAMI-CBUQ) só com pintura na interface; (d) $\mathrm{CP}$ (CBUQ-CBUQ) só com pintura na interface

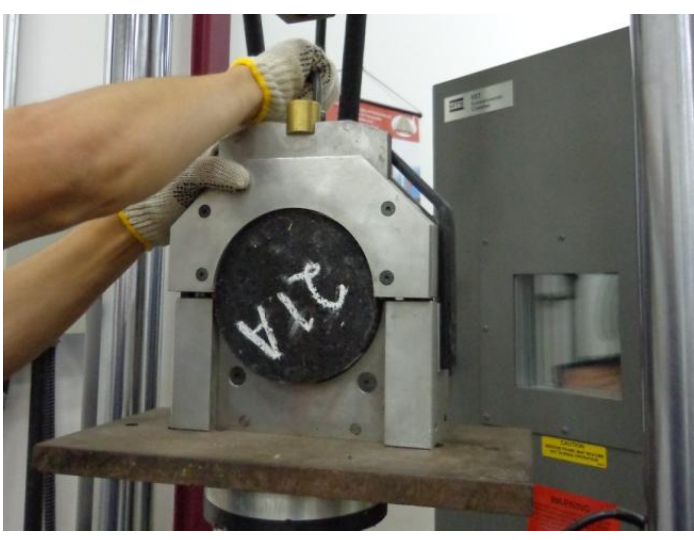

(a)

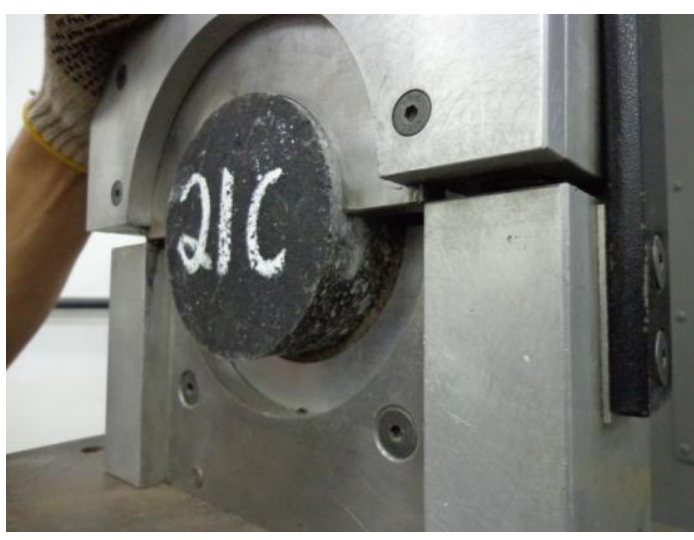

(b)

Figura 3.24 - Preparação dos corpos de prova no equipamento Leutner (a) amostra com $150 \mathrm{~mm}$; (b) amostra com $100 \mathrm{~mm}$ 


\section{APRESENTAÇÃO E DISCUSSÃO DOS RESULTADOS}

Os resultados do teste de cisalhamento direto Leutner foram utilizados para analisar a influência do tipo e da taxa de aplicação da pintura de ligação, além do tamanho da amostra e da textura superficial, na aderência entre camadas asfálticas. Serão apresentados aqui, comparativamente, os resultados para soluções de restauração com e sem uso de geotêxtil/grelha na interface. Da mesma forma, uma análise da influência da velocidade de ensaio nos resultados será confrontada para os dois tipos de emulsão utilizadas (convencional e modificada por polímero). Conforme preconizado na literatura internacional, e descrito no Capítulo 2, o valor máximo de tensão, nos gráficos de tensão versus deslocamento resultantes do ensaio, é diretamente relacionado à resistência ao cisalhamento na interface e, portanto, à aderência entre camadas. A Figura 4.1 apresenta alguns exemplos de corpos de prova após ruptura por cisalhamento, abordados em mais detalhe nos itens a seguir.

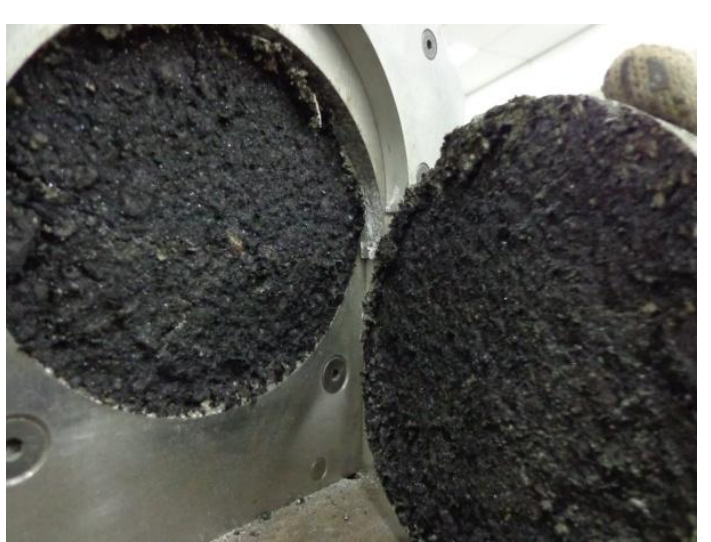

(a)

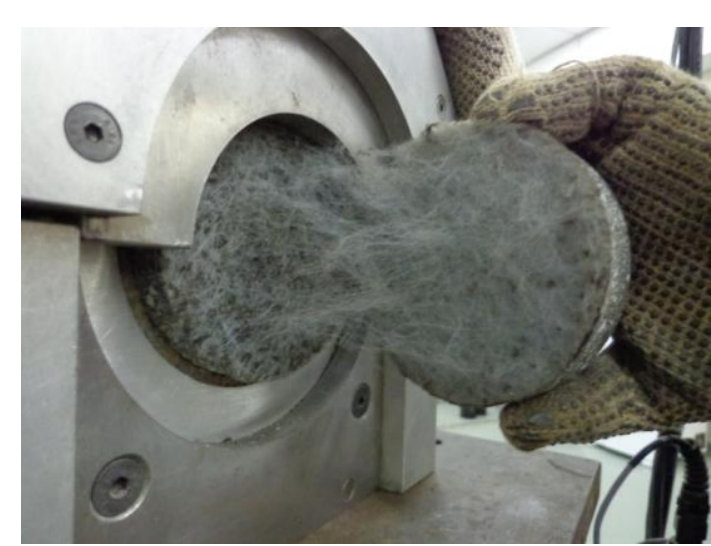

(b) 


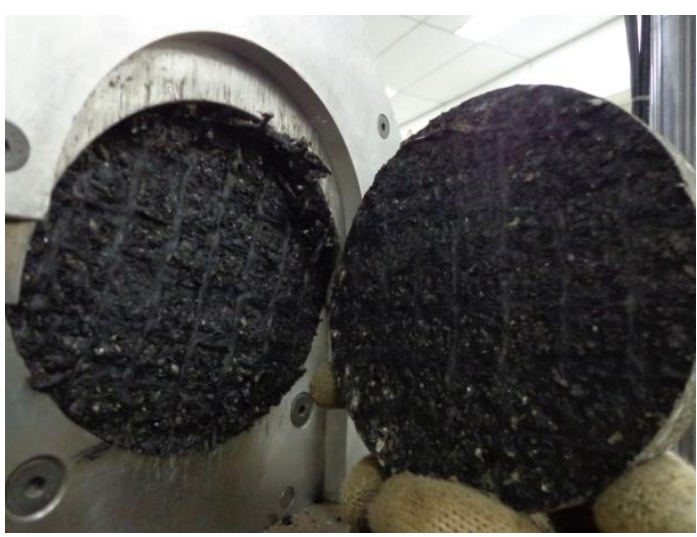

(c)

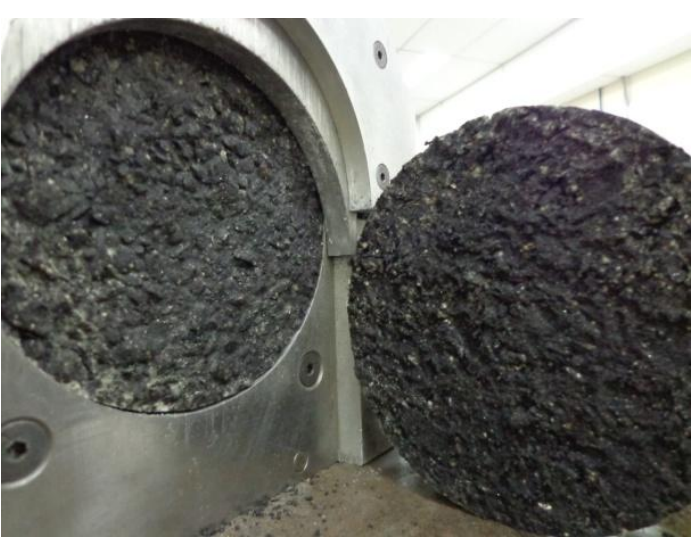

(d)

Figura 4.1 - Corpos de prova após ruptura por cisalhamento: (a) SAMI-CBUQ somente com pintura de ligação na interface; (b) SAMI-CBUQ com geotêxtil+pintura na interface; (c) SAMICBUQ com grelha+pintura na interface; (d) $C B U Q+C B U Q$ somente com pintura de ligação na interface

Durante a realização dos ensaios, percebeu-se que algumas amostras romperam-se na mistura (Figura 4.2) e não no plano de interface entre camadas como era esperado. Esses dados foram eliminados da análise dos resultados para cada um dos casos avaliados. A forma como é feito o broqueamento também pode alterar os resultados do ensaio. Em alguns corpos de prova o broqueamento foi feito sem um nivelamento adequado (Figura 4.3), dificultando a definição correta da interface entre as duas camadas asfálticas.

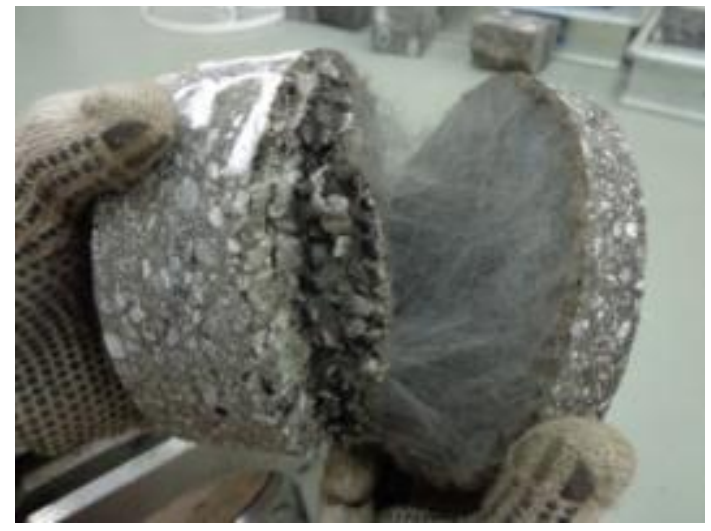

(a)

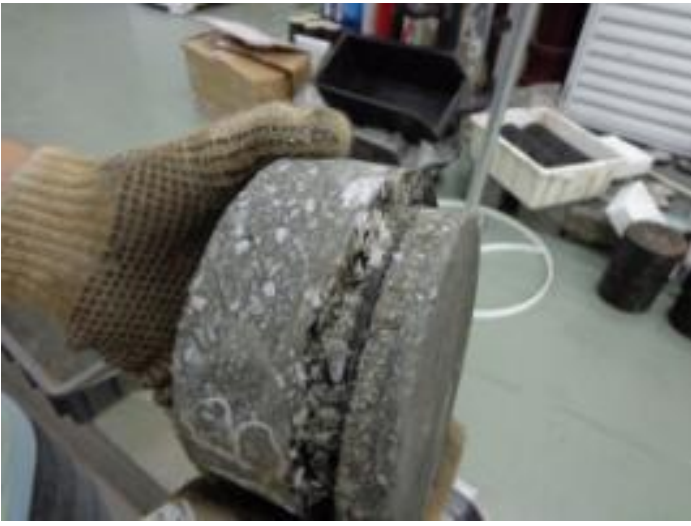

(b)

Figura 4.2 - Corpos de prova que romperam na mistura 


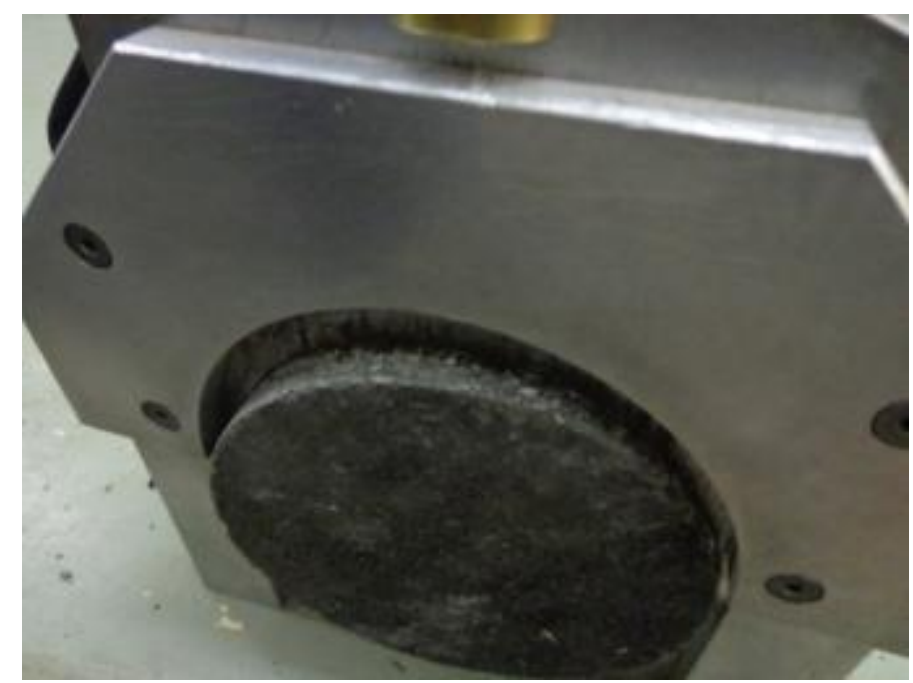

Figura 4.3 - Broqueamento feito de forma desnivelada dificultando a definição da interface entre camadas

Considerando a influência de todas essas variáveis nos resultados, e após exclusão das amostras que tiveram ruptura na mistura, optou-se pela eliminação dos resultados fora do intervalo:

$$
x=\bar{X} \pm s
$$

Onde $\bar{X}$ é a média dos valores encontrados nos ensaios e; s é o desvio padrão dos valores.

Ainda, durante o controle por pesagem da taxa de pintura de ligação aplicada, conforme descrito no Capítulo 3, perceberam-se algumas dificuldades intrínsecas do processo de produção das placas, dentre as quais podem ser citadas:

- A taxa de aplicação da pintura é determinada pela diferença de peso do sistema recipiente+emulsão+pincel antes e após a aplicação. Algumas vezes a taxa aplicada ultrapassa o valor proposto, o que só será percebido após a pesagem.

- A taxa de aplicação de emulsão nas placas com geotêxtil não pode ser mensurada com exatidão já que há uma pequena perda de material sintético durante a pintura. Algumas fibras do geotêxtil ficam aderidas ao pincel, influenciando de forma negativa a pesagem de controle da taxa aplicada.

A Tabela 4.1 traz os valores reais de aplicação em cada caso, onde é possível perceber algumas diferenças entre amostras do mesmo grupo. 
Tabela 4.1 - Taxa real de aplicação de pintura de ligação nas placas moldadas em laboratório

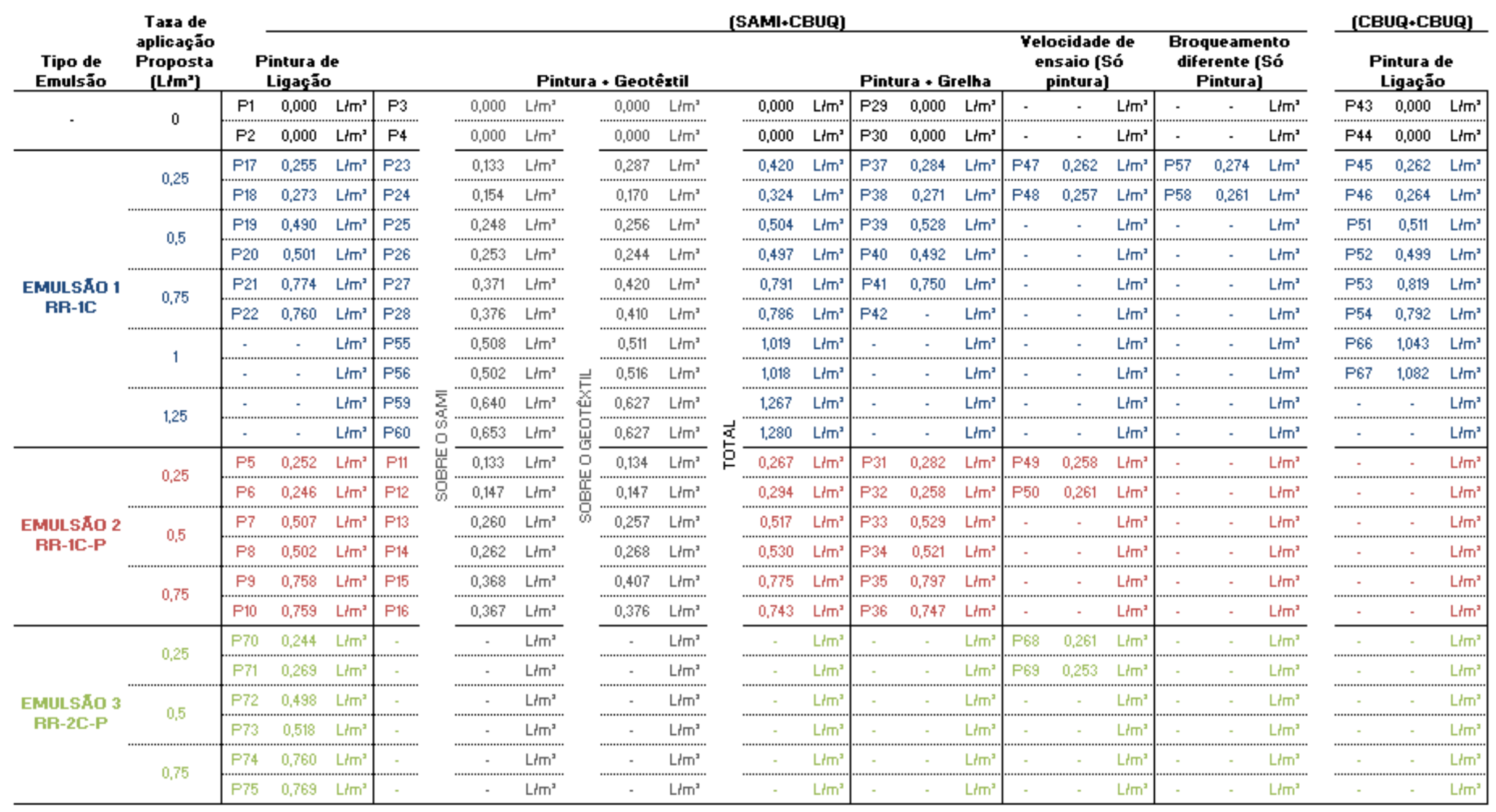




\subsection{EFEITO DA TAXA DE APLICAÇÃO E DO TIPO DE PINTURA DE LIGAÇÃO}

A Figura 4.4 apresenta os valores obtidos para a tensão cisalhante máxima $\left(\tau=\frac{F}{A}\right)$ em função da taxa ideal de aplicação de ligante residual, nos corpos de prova de SAMI-CBUQ somente com pintura de ligação na interface e $150 \mathrm{~mm}$ de diâmetro. As duas emulsões (Emulsão 1, RR-1C; e Emulsão 2, RR-1C-E) são comparadas com o objetivo de avaliar a influência do tipo de pintura na aderência da interface. A taxa de aplicação apresentada está corrigida a partir do ensaio de resíduo por evaporação, apresentado no Capítulo 3, para os dois tipos de emulsão.

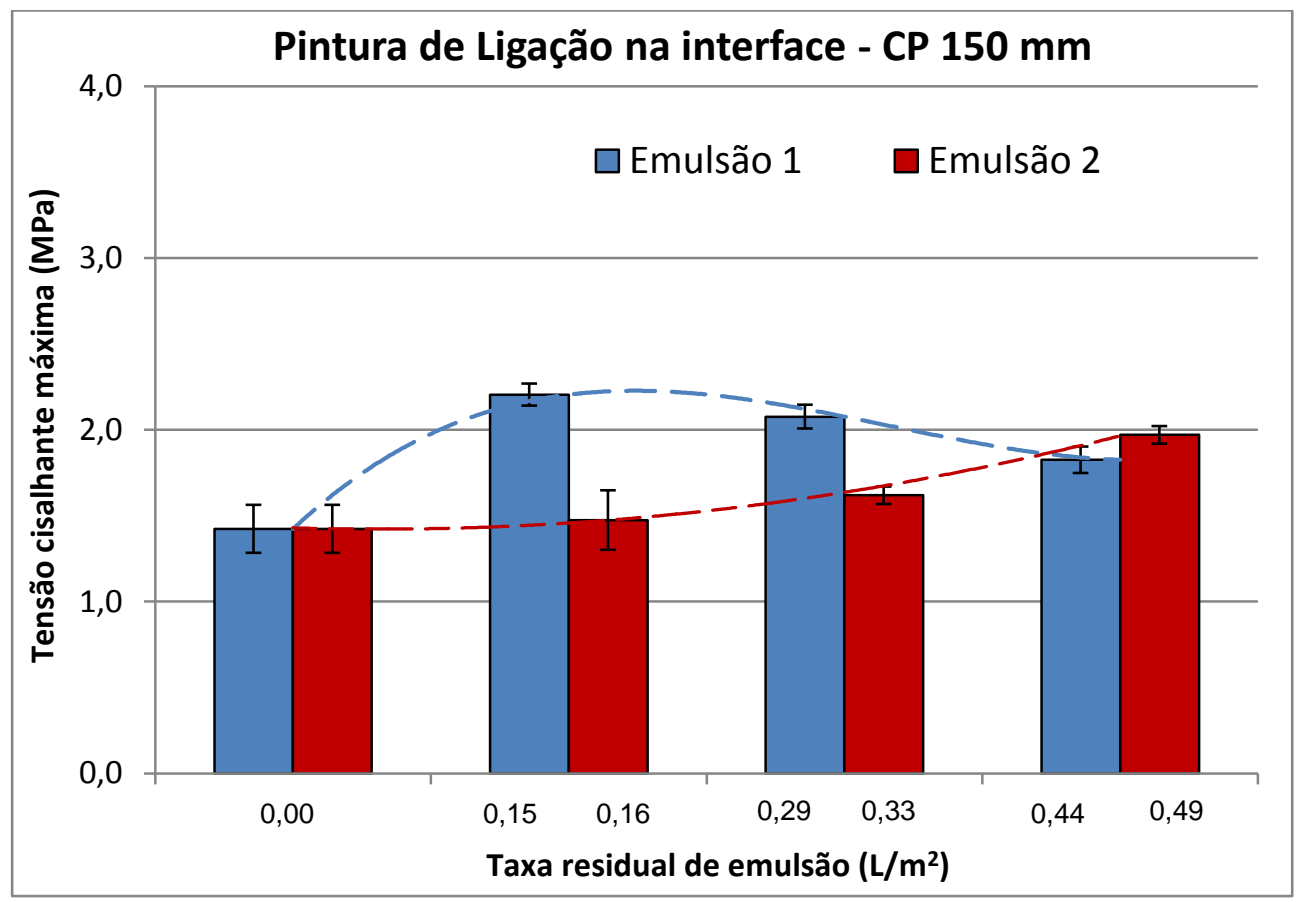

Figura 4.4 - Tensão cisalhante máxima versus taxa de aplicação da pintura de ligação amostras de $150 \mathrm{~mm}$ de diâmetro só com pintura de ligação na interface

Para os casos com pintura de ligação na interface, percebe-se da Figura 4.4, que os valores de tensão cisalhante máxima apresentaram um pico de taxa ótima de aplicação para a Emulsão 1 próximo ao valor de $0,15 \mathrm{~L} / \mathrm{m}^{2}$ de ligante residual. Para a Emulsão 2, porém, não foi possível estabelecer um valor ótimo com as taxas analisadas.

Estudos anteriores apontaram dificuldade na determinação da taxa ótima de emulsão (BAE et al., 2010). Os autores avaliaram, por meio do ensaio LISST (ver Figura 2.14 no Capítulo 2), dois tipos de pintura de ligação, uma com asfalto residual 
classificado como PG 58-28 e outro classificado como PG 82 (não foi especificado a temperatura mínima do PG para o segundo ligante), em três diferentes taxas de aplicação (de ligante residual), 0,14; 0,28 e 0,70 L/m². Para ambas as emulsões não foi possível determinar a taxa de aplicação ótima, uma vez que não se observou o aumento e posterior queda do valor de resistência ao cisalhamento.

Um comparativo do desempenho das duas emulsões ainda leva a concluir que, de forma geral, os valores de resistência ao cisalhamento da Emulsão 2 foram inferiores aos valores obtidos para a Emulsão 1. Considerando a maior viscosidade da Emulsão 2 (modificada por polímero SBR) e os estudos de Chen e Huang (2010), Mohammad et al. (2002) e West et al. (2005), que demonstraram que uma maior viscosidade influencia positivamente na aderência da interface, o resultado encontrado contradiz as expectativas.

Recasens et al. (2006) compararam a eficiência de uma emulsão convencional, com algumas emulsões adesivas. Em temperaturas intermediárias de ensaio (entre $5^{\circ} \mathrm{C}$ e $20^{\circ} \mathrm{C}$ ), algumas dessas emulsões adesivas apresentaram resultados superiores, enquanto outras apresentaram resultados inferiores, com relação à emulsão convencional. Os autores mencionam que os resultados de resistência ao cisalhamento das interfaces são dependentes tanto do ligante puro utilizado, como do tipo de modificador.

Por esse motivo, testou-se uma terceira emulsão, também modificada com polímero, do tipo RR-2C-E, conforme descrito no Capítulo 3. Os resultados estão apresentados na Figura 4.5 abaixo. Os valores de tensão cisalhante máxima para a Emulsão 3 superaram os valores obtidos com as outras duas emulsões, comprovando que emulsões modificadas podem ter desempenho melhor que emulsões convencionais. As Emulsões 2 e 3, apesar de ambas serem modificadas, foram produzidas por fabricantes distintos, tendo provavelmente o ligante base também características diferentes. Os dados mostram que a viscosidade pode ter efeito positivo na aderência entre camadas (comparação da Emulsão 1 e 3), porém, esse parâmetro isolado não parece ser suficiente, uma vez que a Emulsão 2 apresentou valores inferiores de tensão de cisalhamento máxima. 


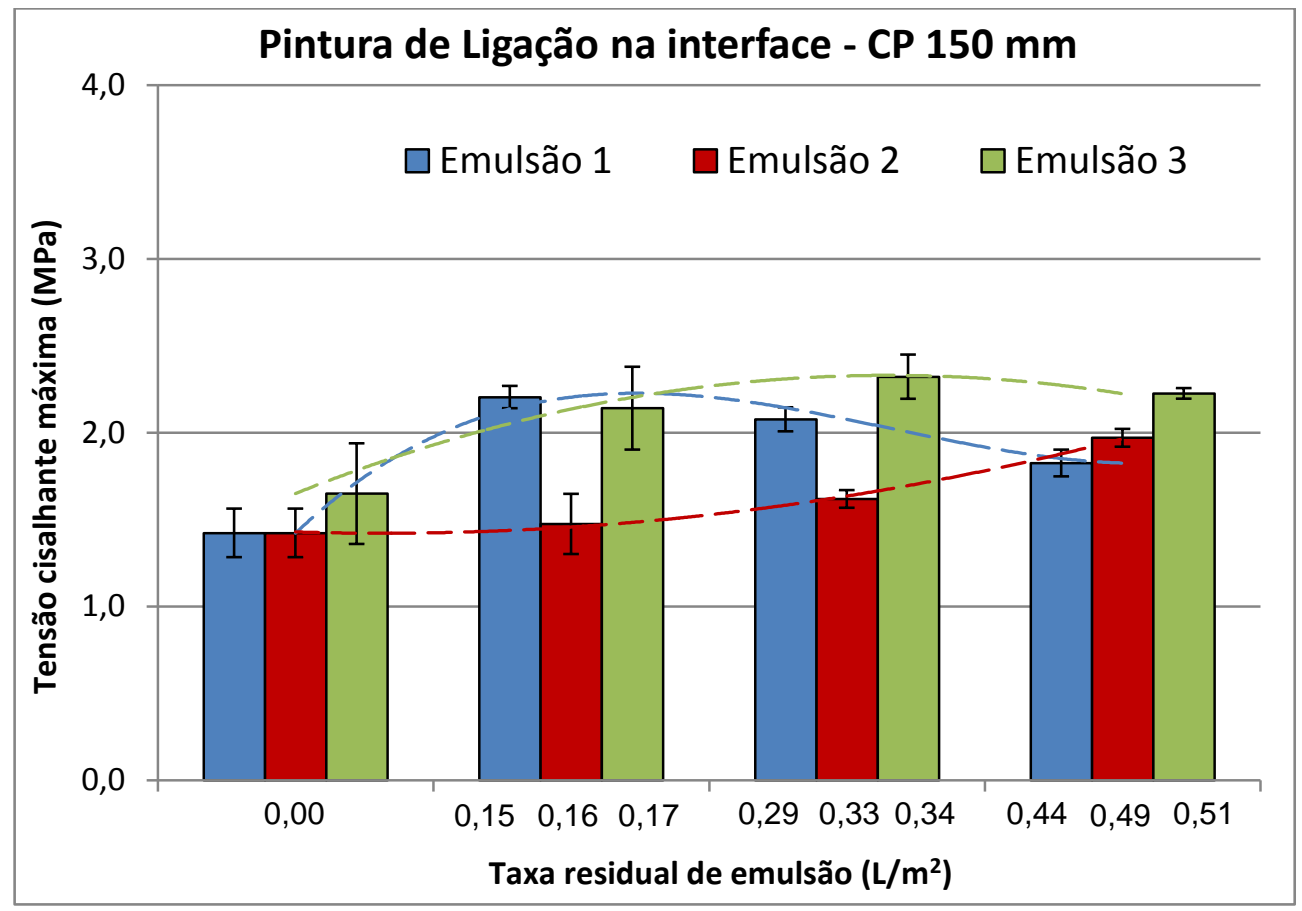

Figura 4.5 - Tensão de cisalhante máxima versus taxa de aplicação da pintura de ligação comparativo entre Emulsão 1, 2 e 3

Para a Emulsão 3, ainda percebe-se um pico no gráfico de tensão máxima para taxa residual aproximada de $0,34 \mathrm{~L} / \mathrm{m}^{2}$. A maior viscosidade pode explicar 0 valor de taxa ótima um pouco maior para a Emulsão 3, quando comparado à taxa ótima da Emulsão 1 (em torno de $0,15 \mathrm{~L} / \mathrm{m}^{2}$ ). No processo de produção de misturas asfálticas com uso de ligantes modificados, ou de alta viscosidade, geralmente necessita-se de maior teor de ligante para manter as mesmas características volumétricas da mistura (VASCONCELOS et al., 2011).

\subsection{EFEITO DA VELOCIDADE DE ENSAIO PARA OS DIFERENTES TIPOS DE EMULSÃO}

A partir dos baixos valores de aderência com o uso da Emulsão 2 (RR-1C-E), apresentados no item 4.1, procurou-se avaliar a influência da velocidade de ensaio nos resultados, principalmente em ligantes modificados por polímero, visto que a taxa de carregamento tem efeito significativo em materiais viscoelásticos (BAHIA et al., 1997).

Foram realizados ensaios com carregamento monotônico e velocidade de 1,0 $\mathrm{mm} / \mathrm{min}$ nas amostras só com pintura de ligação na interface e taxa de aplicação de 
emulsão de $0,25 \mathrm{~L} / \mathrm{m}^{2}$, para as três emulsões analisadas. A velocidade é relativamente baixa, aproximadamente metade do valor usado por Uzan et al. (1978), quatro vezes menor do que a utilizada no ensaio de cisalhamento adaptado pelo Laboratoire Régional de l'Ouest Parisien (LROP) (Abdo et al., 2001 apud Recasens et al., 2005) e cinquenta vezes vezes menor do que a velocidade normatizada pelo ensaio Leutner.

Conforme descrito no Capítulo 3, para realização dos ensaios à baixa velocidade, utilizou-se câmara de controle de temperatura, de forma a não haver variação da temperatura ao longo do ensaio $\left(20^{\circ} \mathrm{C}\right)$, visto que o mesmo leva mais tempo para ser executado. Os resultados, para corpos de prova de $150 \mathrm{~mm}$, seguem descritos na Figura 4.6. Como esperado, a taxa de carregamento exerce grande influência em materiais asfálticos (quanto maior a taxa, maior a rigidez da amostra) (Kim et al., 1995). Percebe-se que os resultados de tensão cisalhante máxima para a baixa velocidade de ensaio igualam-se para as três emulsões. Diante dos resultados, considerando que o material se comporta como termorreologicamente simples, acredita-se que as três emulsões avaliadas apresentariam comportamento semelhantes caso fossem testadas em temperaturas mais elevadas.

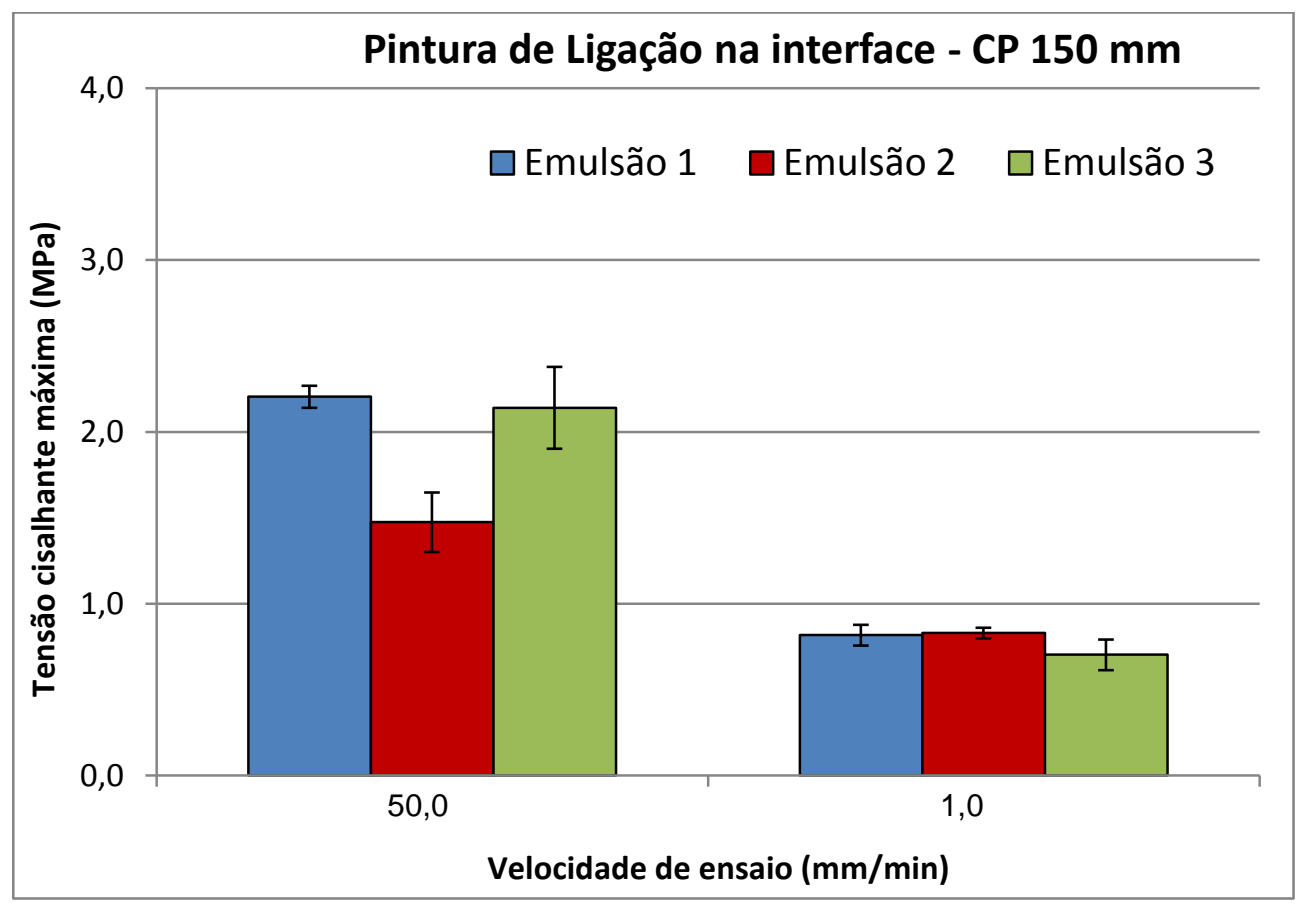

Figura 4.6 - Tensão cisalhante máxima para diferentes velocidades de ensaio (CP $150 \mathrm{~mm}$ ) 


\subsection{EFEITO DO TAMANHO DA AMOSTRA NO ENSAIO DE CISALHAMENTO DIRETO LEUTNER}

Para as três emulsões analisadas nos itens 4.1 e 4.2, foram testados corpos de prova de $100 \mathrm{~mm}$ de diâmetro para comparação com as amostras normatizadas de $150 \mathrm{~mm}$ de diâmetro. Os resultados seguem apresentados nas Figuras 4.7 a 4.10.

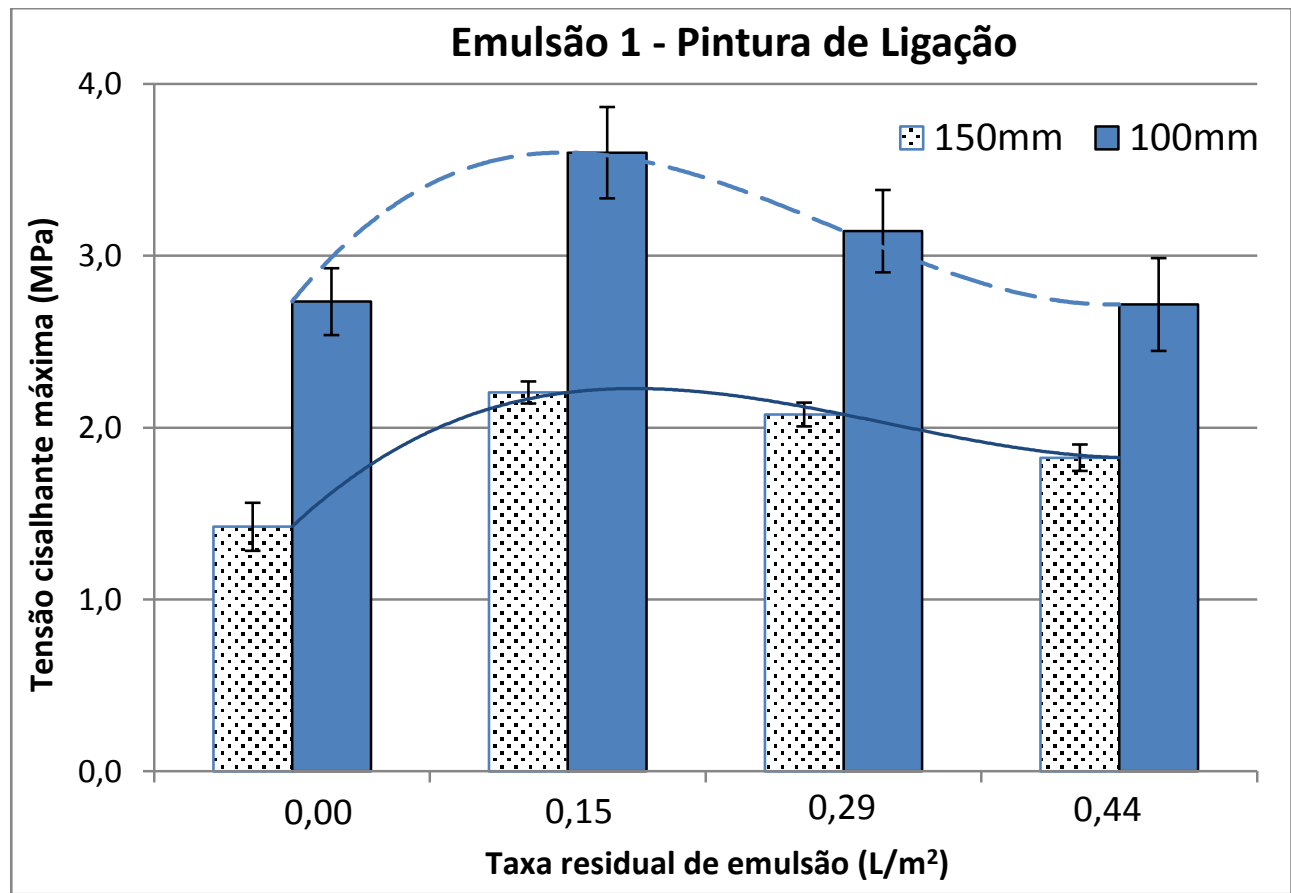

Figura 4.7 - Tensão cisalhante máxima para diferentes tamanhos de amostra (Emulsão 1) 


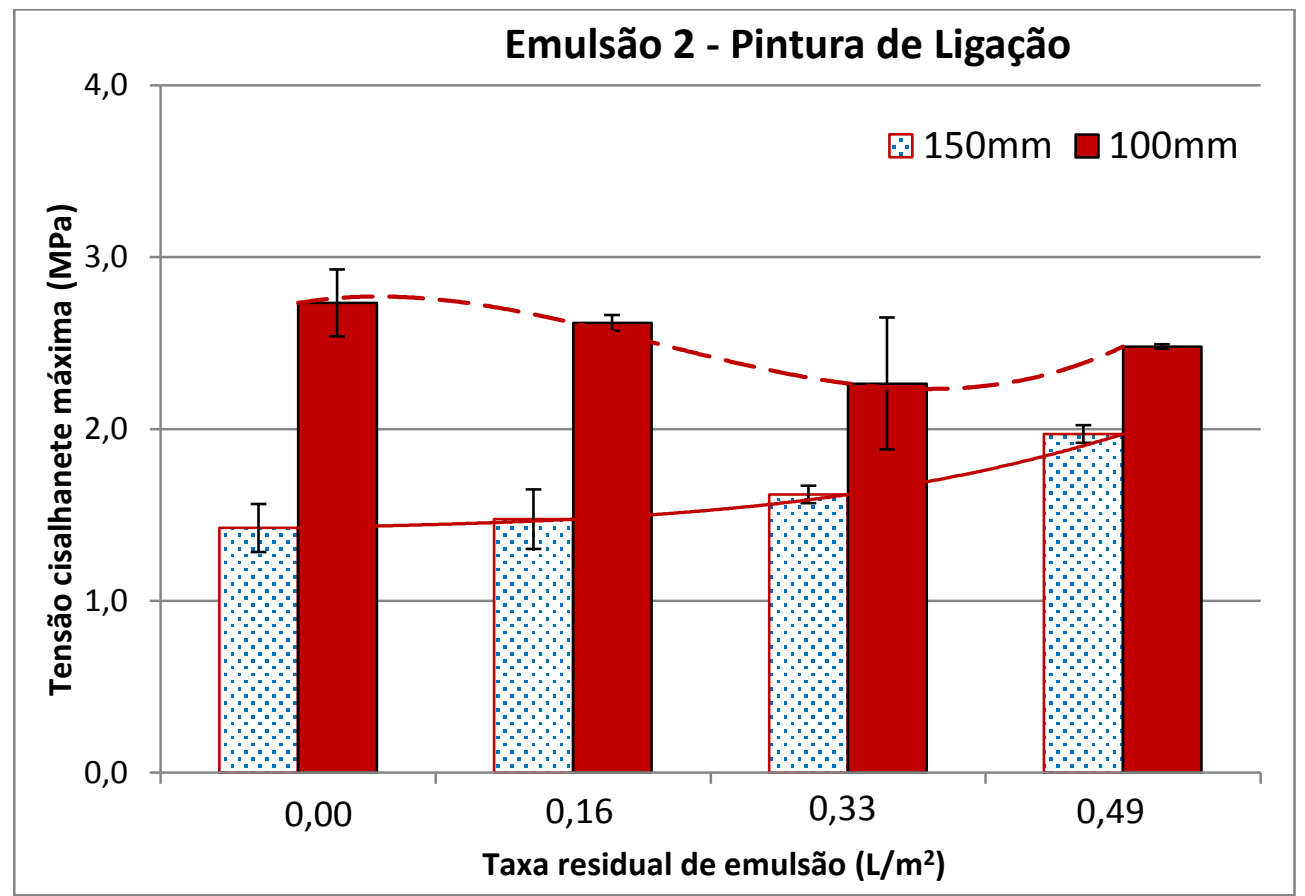

Figura 4.8 - Tensão cisalhante máxima para diferentes tamanhos de amostra (Emulsão 2)

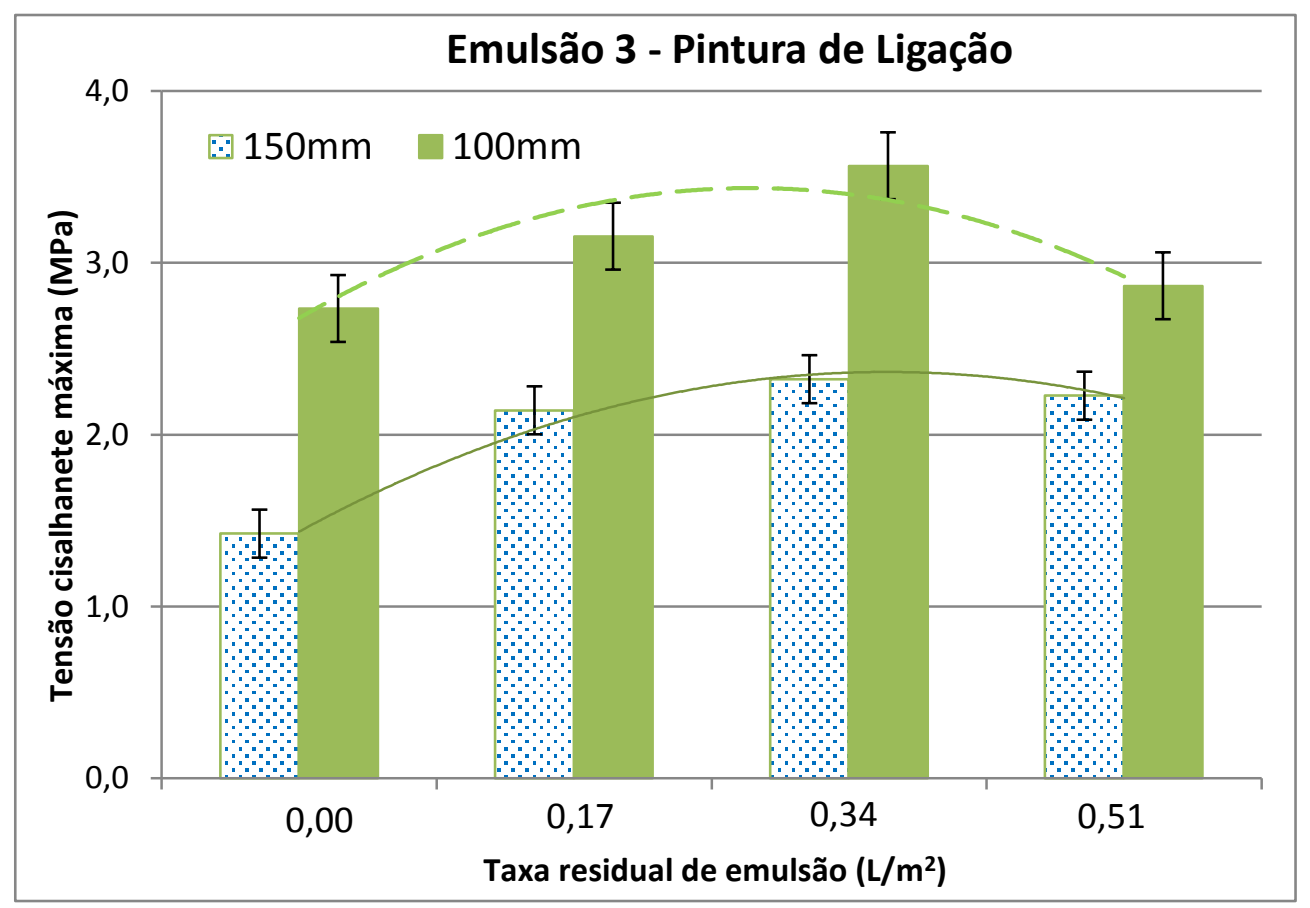

Figura 4.9 - Tensão cisalhante máxima para diferentes tamanhos de amostra (Emulsão 3)

Com relação ao tamanho das amostras, uma diferença significativa foi observada nos valores de tensão em todos os teores de emulsão. Os resultados para as amostras de 100 mm de diâmetro seguiram a mesma tendência em função 
da taxa de aplicação de pintura, comparados aos corpos de prova com $150 \mathrm{~mm}$, porém com valores bem maiores.

Como primeira hipótese para explicar os maiores valores de tensão para as amostras com menor diâmetro, moldaram-se duas novas placas com taxa de 0,25 $\mathrm{L} / \mathrm{m}^{2}$ de Emulsão 1 propondo novo formato de broqueamento. Na metodologia original foram extraídos, das placas com pintura de ligação na interface, dois corpos de prova de $150 \mathrm{~mm}$ nas pontas e um de $100 \mathrm{~mm}$ no centro. Das duas novas placas extraiu-se uma amostra de $150 \mathrm{~mm}$ no centro e duas de $100 \mathrm{~mm}$ nas pontas, conforme ilustrado na Figura 4.10. A partir dos resultados apresentados na Figura 4.11, percebe-se que não houve influência do posicionamento da amostra ao longo da placa compactada na aderência entre camadas.

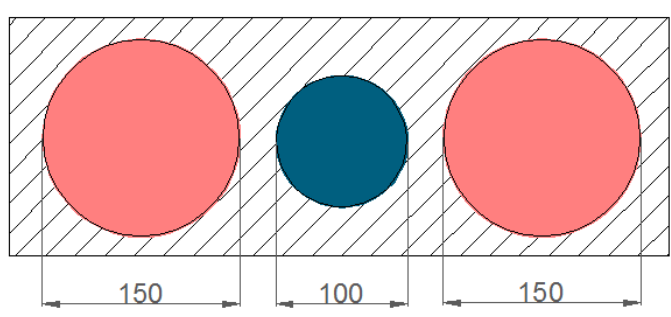

(a)

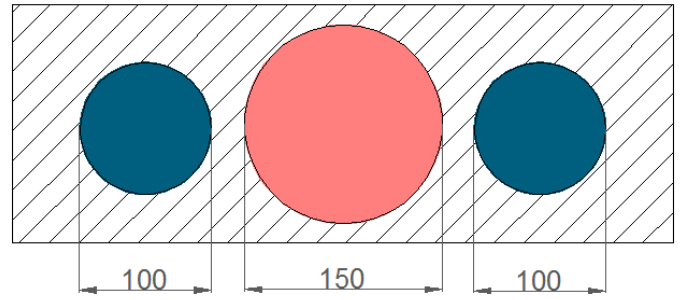

(b)

Figura 4.10 - (a) Posição original do broqueamento das amostras com pintura de ligação na interface e (b) novo posicionamento testado (Emulsão 1 a $0,25 \mathrm{~L} / \mathrm{m}^{2}$ )

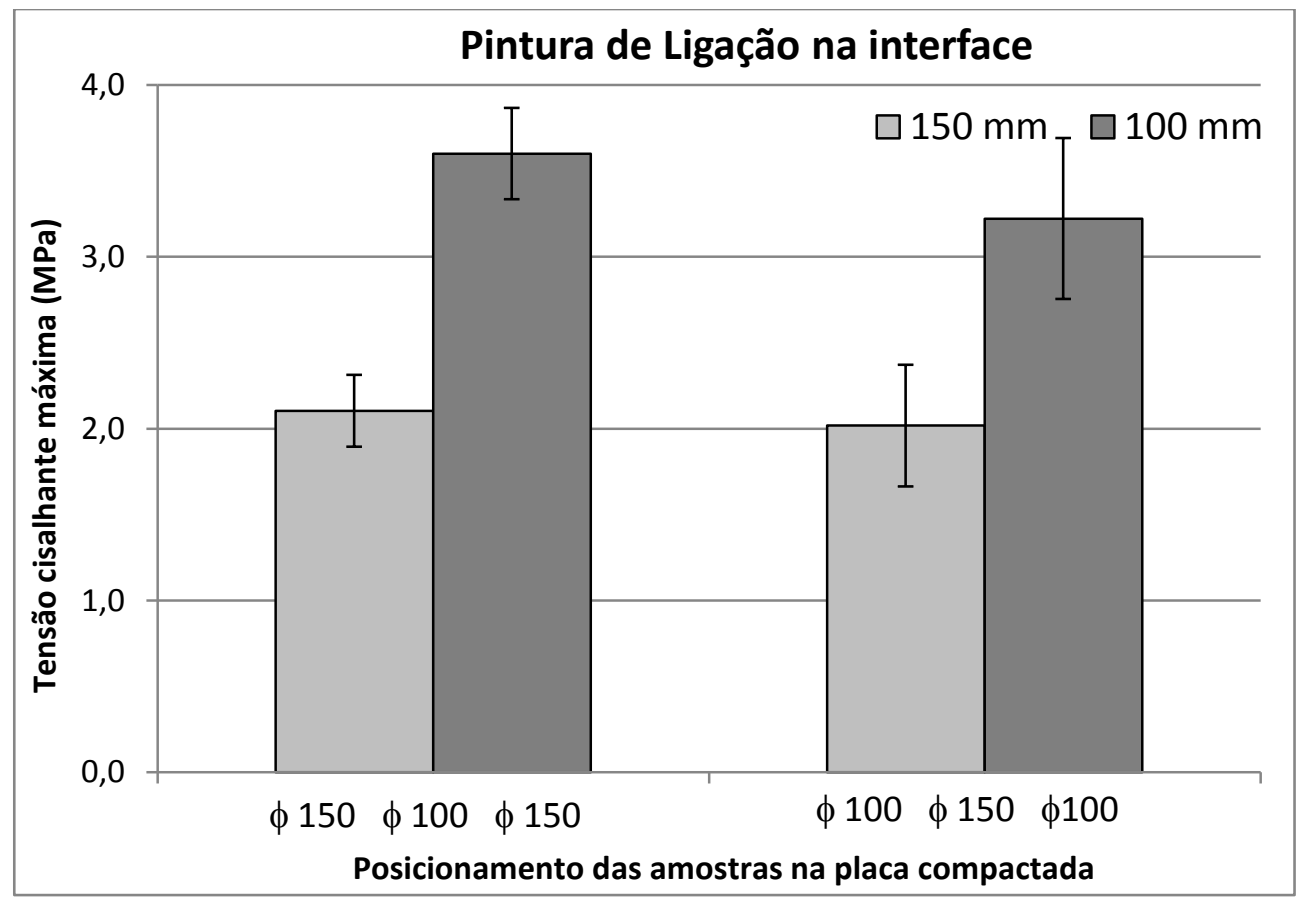

Figura 4.11 - Tensão cisalhante máxima para diferentes posicionamentos de extração das amostras cilíndricas 
Analisando os gráficos de tensão cisalhante versus deslocamento, percebe-se clara diferença entre o comportamento das curvas para os corpos de prova com as duas dimensões de amostras, conforme Figura 4.12, principalmente no que tange à inclinação da curva antes do pico de tensão. A inclinação do gráfico até o ponto de tensão máxima é muitas vezes referenciada como módulo de reação da interface, parâmetro de entrada para modelagem do contato entre camadas, conforme abordado no Capítulo 2, Figura 2.4. Esse tema será melhor detalhado no item 4.6 adiante. Ensaios de cisalhamento em outros materiais de engenharia civil indicam a existência de uma maior concentração de tensões no início do plano de cisalhamento, quanto menor o tamanho da amostra.

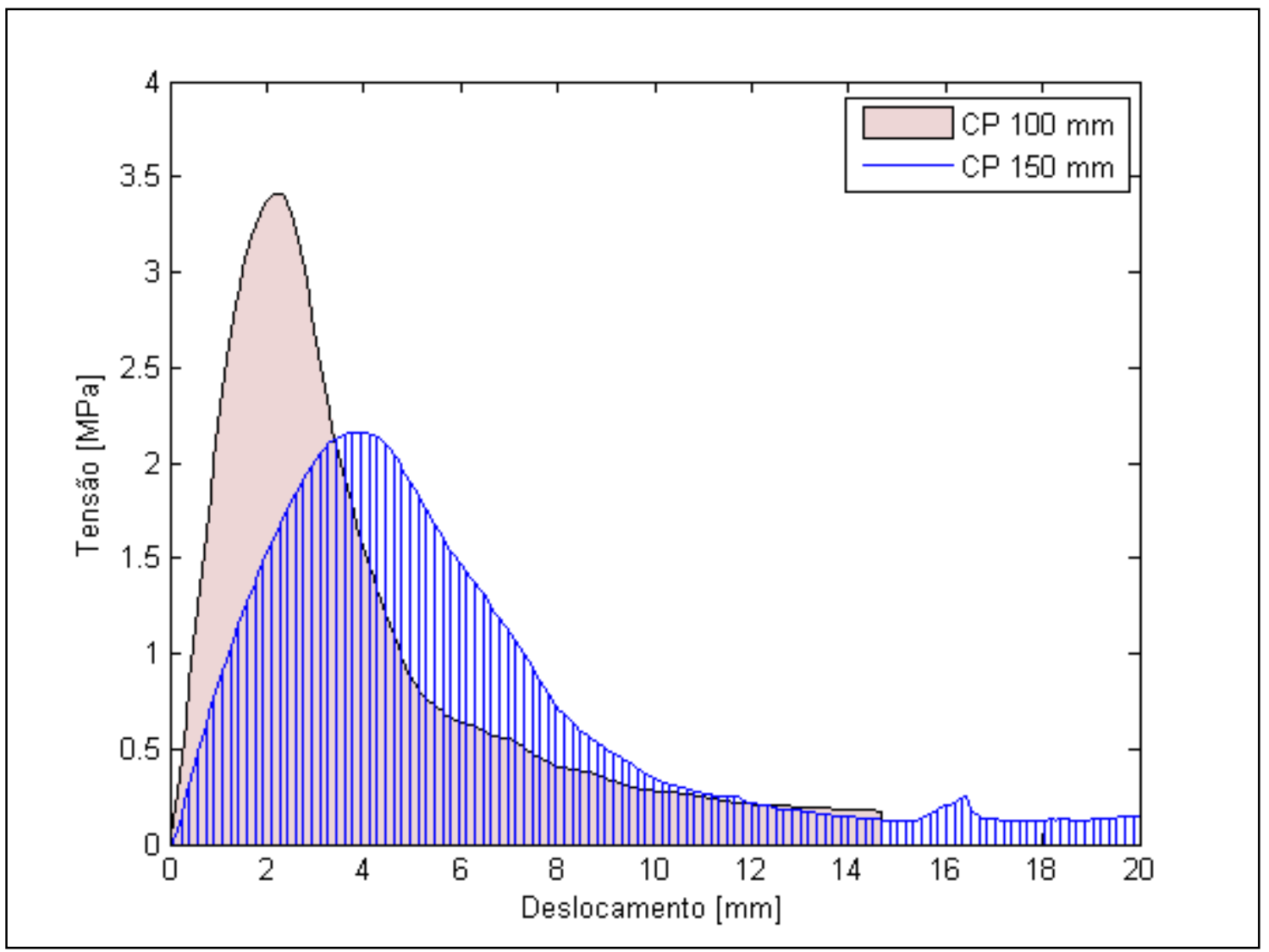

Figura 4.12 - Comportamento da curva de tensão cisalhante máxima versus deslocamento para amostras de 100 e $150 \mathrm{~mm}$ de diâmetro. 


\subsection{EFEITO DO USO DE SISTEMAS ANTI-REFLEXÃO DE TRINCAS NA INTERFACE - GEOTÊXTIL E GRELHA}

Os resultados de tensão cisalhante máxima foram analisados, comparativamente, entre placas de SAMI-CBUQ com uso ou não de materiais de reforço anti-reflexão de trincas na interface. Para cada um dos materiais (um geotêxtil não tecido e uma grelha de fibra de vidro) variou-se tipo (Emulsão 1 e Emulsão 2) e taxa de pintura de ligação $(0,0 ; 0,25 ; 0,50 ; 0,75)$. Nas amostras com geotêxtil na interface, o comportamento com o uso dos dois tipos de emulsão encontra-se apresentado na Figura 4.13.

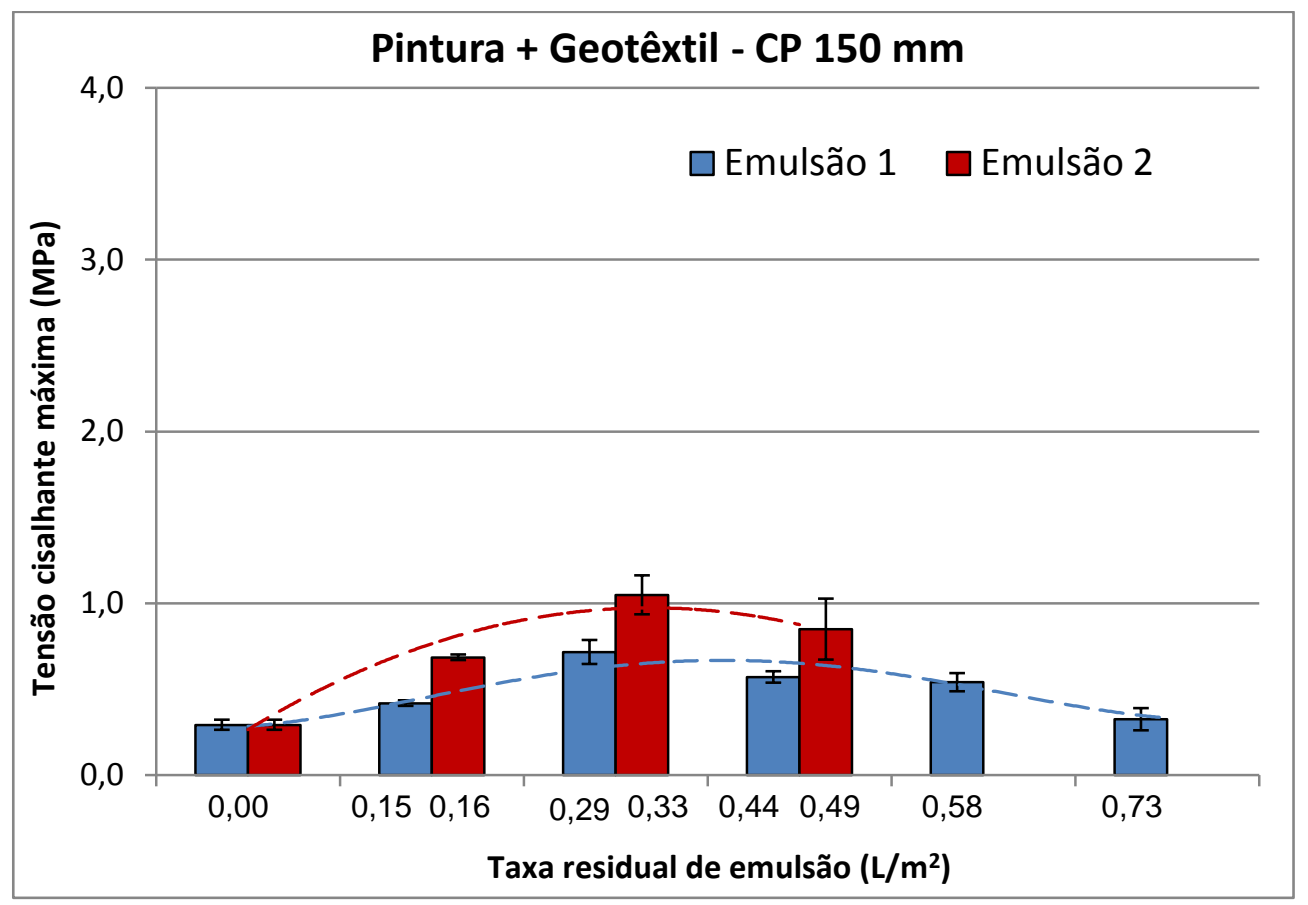

Figura 4.13 - Tensão cisalhante versus taxa de aplicação da pintura de ligação - Amostras de $150 \mathrm{~mm}$ de diâmetro, com pintura e geotêxtil na interface

As amostras com geotêxtil apresentaram pico de tensão cisalhante máxima, nos dois casos, para taxas semelhantes, sendo os valores com a Emulsão 2 (modificada) maiores em comparação à Emulsão 1. A absorção do ligante pelo material que compõe o geotêxtil, provavelmente, ocorre em menor intensidade na presença do ligante mais viscoso, da Emulsão 2, fazendo com que a pintura esteja concentrada na interface entre o geotêxtil e a mistura asfáltica. Para a Emulsão 1 foram moldadas amostras com taxas complementares de 1,00 e 1,25 L/m² para 
constatação do pico de tensão máxima do gráfico. Para ambas as emulsões, a taxa de aplicação residual ótima ficou próxima de $0,30 \mathrm{~L} / \mathrm{m}^{2}$. Observa-se também que além de uma taxa ótima mais elevada (quando comparado com a interface somente com a pintura de ligação), os valores de tensão cisalhante máxima são consideravelmente inferiores quando da aplicação do geotêxtil, fato já observado por outros autores em diferentes condições de ensaio (RAAB e PARTL, 2004; BAZARRA et al., 2010).

A Figura 4.14 a seguir traz os resultados comparativos do tipo e taxa de pintura de ligação para as amostras com grelha na interface.

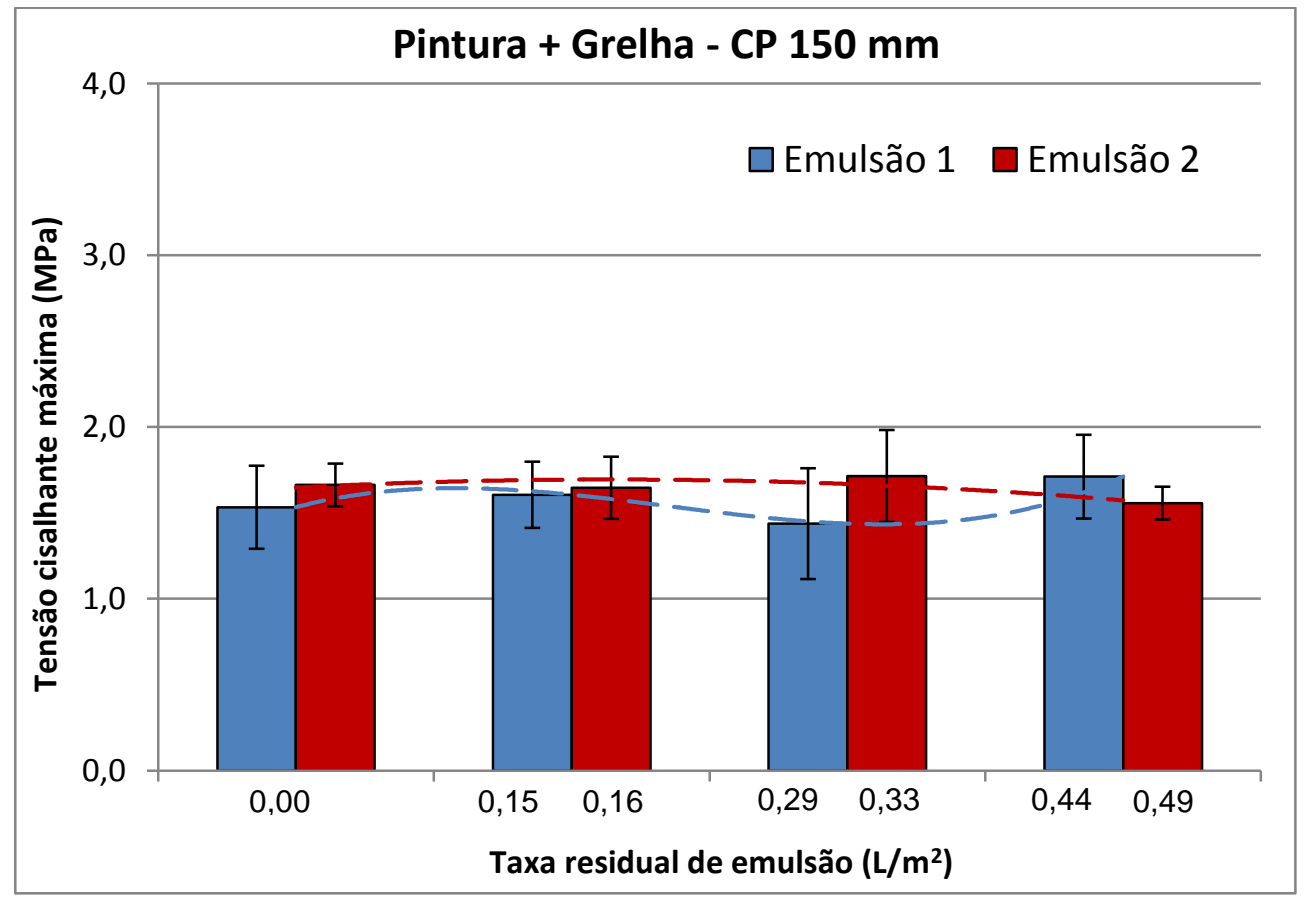

Figura 4.14 - Tensão cisalhante versus taxa de aplicação da pintura de ligação - Amostras de $150 \mathrm{~mm}$ de diâmetro, com pintura e grelha na interface

Os resultados não apresentaram pico definido na curva para nenhuma das taxas ou tipos de emulsão analisados. Durante a realização do ensaio Leutner, observou-se que, nas amostras com grelha, os corpos de prova após ruptura apresentavam-se em duas configurações diferentes: i) a direção de cisalhamento das amostras cilíndricas ocorreu de forma a acompanhar o sentido ortogonal da malha da grelha (Figura 4.15 (a)); ou ii) a direção de cisalhamento ocorreu em sentido diagonal ao posicionamento da grelha (Figura 4.15 (b)). Em todos os outros casos de tratamento na interface não houve preocupação inicial com controle do 
direcionamento do cisalhamento. Para as amostras com grelha, porém, esse controle se mostrou relevante. Uma sequência de placas com grelha e Emulsão 1, nas mesmas taxas aplicadas anteriormente, foi refeita e os resultados estão apresentados na Figura 4.16.

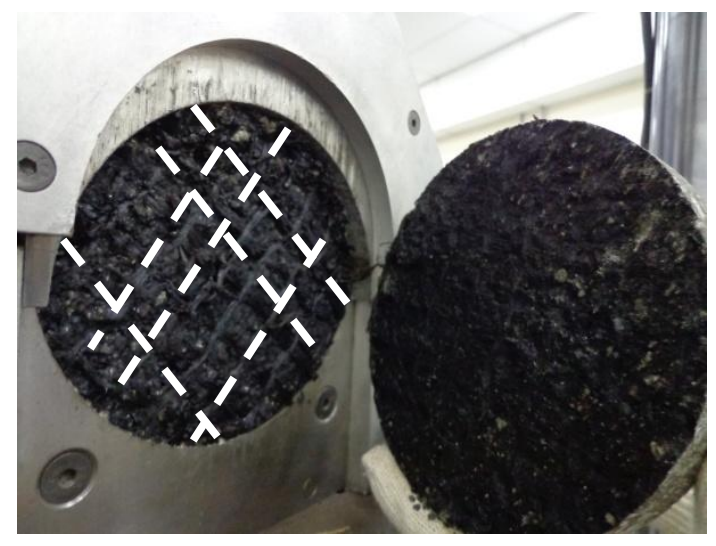

(a)

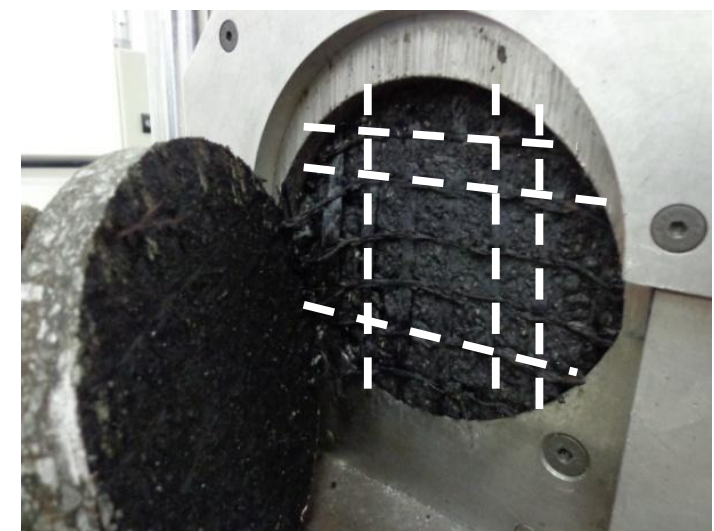

(b)

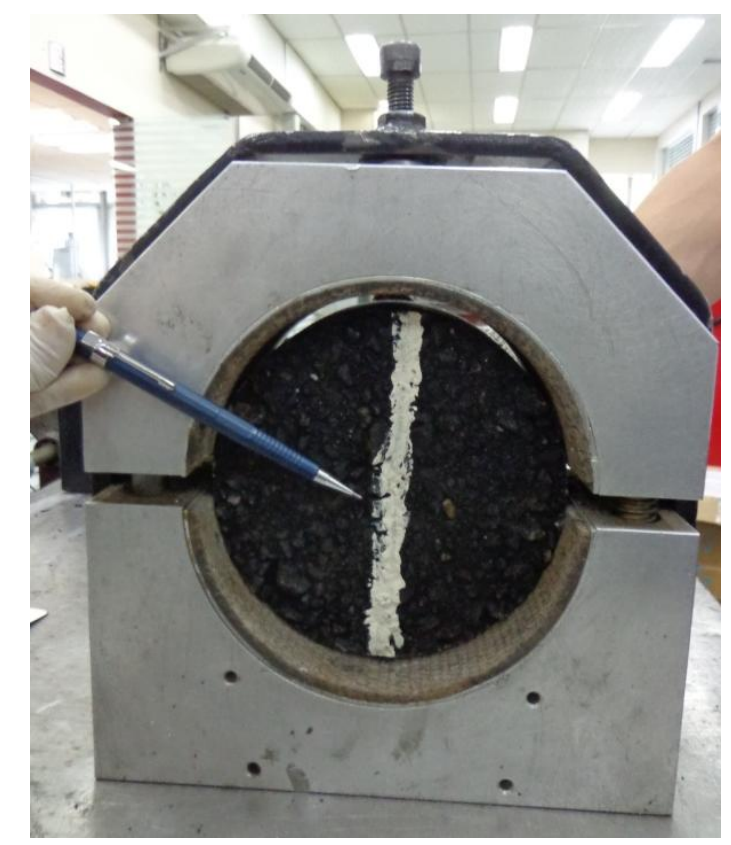

(c)

Figura 4.15 - Corpos de prova com pintura+grelha onde (a) a ruptura ocorreu em direção diagonal à malha da grelha; $\mathrm{e}$ (b) a ruptura ocorreu na mesma direção da grelha. (c) Direção de ruptura controlada para ensaios refeitos para Emulsão 1 


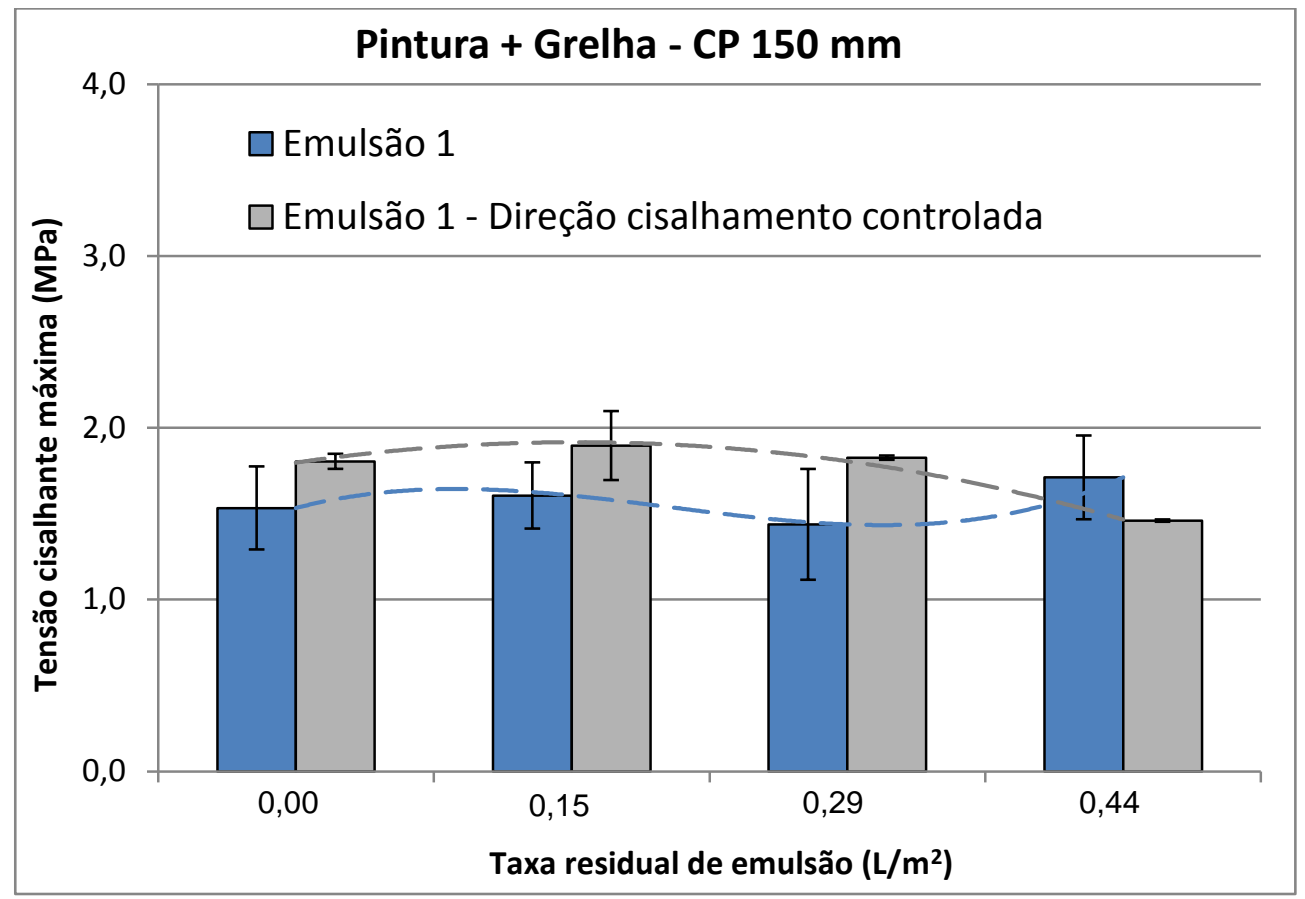

Figura 4.16 - Tensão cisalhante versus taxa de aplicação da pintura de ligação - Amostras de $150 \mathrm{~mm}$ de diâmetro, com pintura e grelha na interface

Da Figura 4.16 percebe-se que os valores de tensão em função da taxa de pintura de ligação apresentaram curva com pequeno pico pronunciado para as amostras com direção de cisalhamento controlada. Esse controle se mostrou, portanto, importante durante a execução do ensaio. A interface Grelha + Emulsão 1 apresentou leve pico de tensão para taxa de ligante residual de $0,15 \mathrm{~L} / \mathrm{m}^{2}$, não influenciando portanto a taxa ótima nos casos sem esse material na interface. Vale ressaltar que a grelha analisada é fornecida com impregnação prévia de asfalto. Casos com grelhas sem essa impregnação podem resultar em taxas ótimas diferentes. A Figura 4.17 traz um comparativo entre as três soluções de restauração para o caso da Emulsão 1: somente pintura de ligação na interface, pintura+geotêxtil e pintura+grelha. 


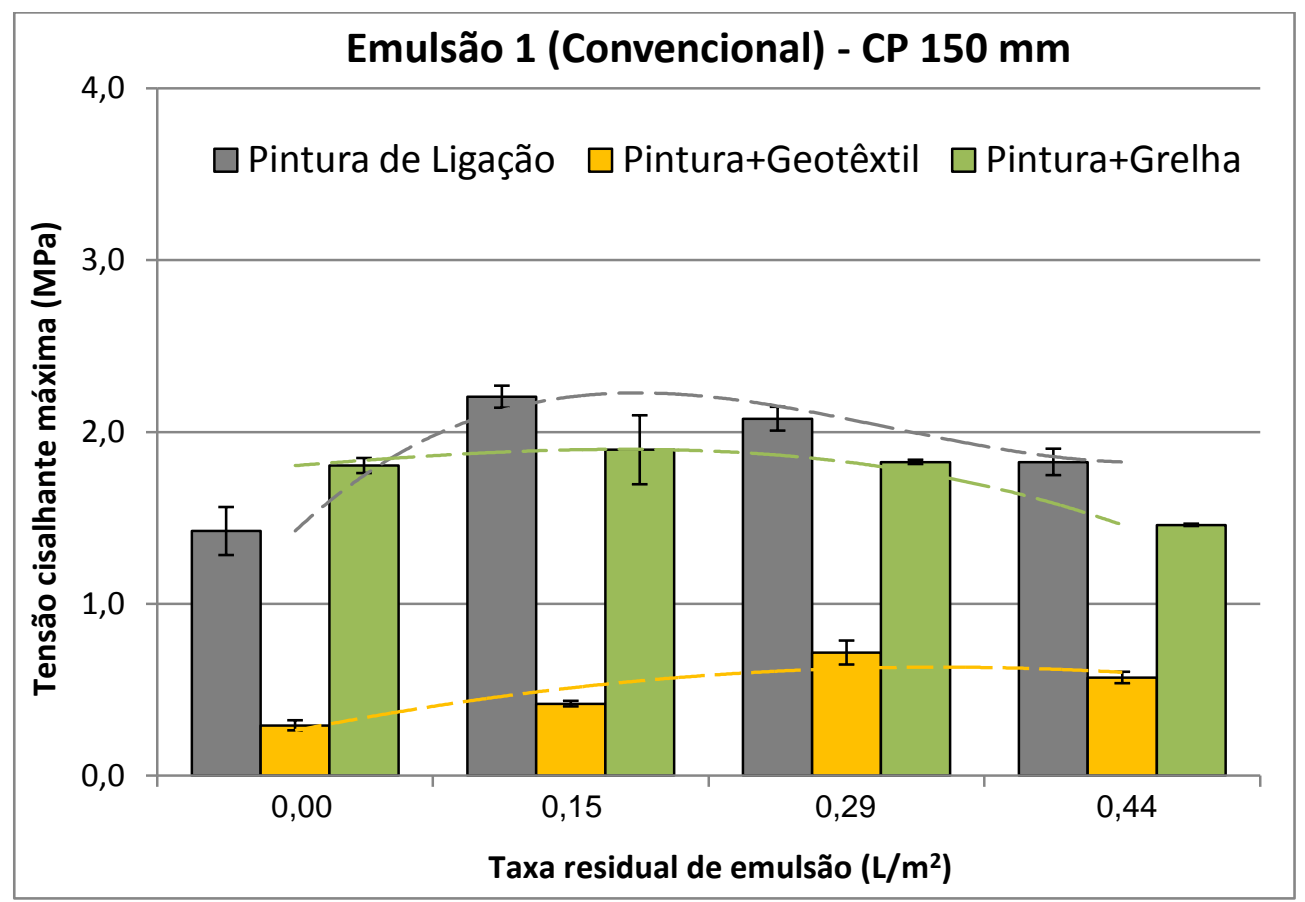

Figura 4.17 - Tensão cisalhante versus taxa de aplicação da pintura de ligação - Amostras de $150 \mathrm{~mm}$ de diâmetro, com pintura e grelha na interface

Como esperado, a presença de sistemas anti-reflexão de trincas na interface, apesar de ter bom comportamento frente ao fenômeno de reflexão de trincas, tem influência negativa na aderência entre camadas, porque implica em perda parcial do contato entre as misturas asfálticas. Para as amostras com geotêxtil, a perda de aderência na interface fica evidenciada pelos baixos valores de tensão cisalhante. $O$ valor máximo de tensão obtido para esse material está aquém dos menores valores obtidos no caso somente com pintura de ligação na interface. A manta geotêxtil, para o estudo da aderência entre camadas, funciona como isolante que anula o intertravamento mecânico entre as camadas asfálticas. Bazarra et al. (2010) desenvolveram nova metodologia de ensaio para análise de aderência com e sem a presença de geossintéticos na interface. Para as amostras com geotêxtil na interface os valores obtidos também eram bem menores quando comparados aos casos sem a presença do material.

Os valores de tensão máxima para a grelha utilizada na confecção dos corpos de prova apresentaram-se menores, porém muito próximos aos valores obtidos com uso apenas de pintura de ligação na interface. A grelha, por possuir malha vazada, permite o contato direto entre as camadas, e ainda é impregnada com material 
asfáltico, o que motiva o valor pontual de tensão mais alto para o caso sem pintura de ligação (taxa $\left.0,0 \mathrm{~L} / \mathrm{m}^{2}\right)$.

\subsection{EFEITO DA TEXTURA SUPERFICIAL DAS CAMADAS}

A influência da textura superficial das camadas na aderência interfacial entre as mesmas foi avaliada em placas de SAMI-CBUQ e CBUQ-CBUQ. Para os dois casos, os resultados seguem apresentados nas Figuras 4.18 (CPs de 150 mm de diâmetro) e 4.19 (CPs de $100 \mathrm{~mm}$ ) abaixo.

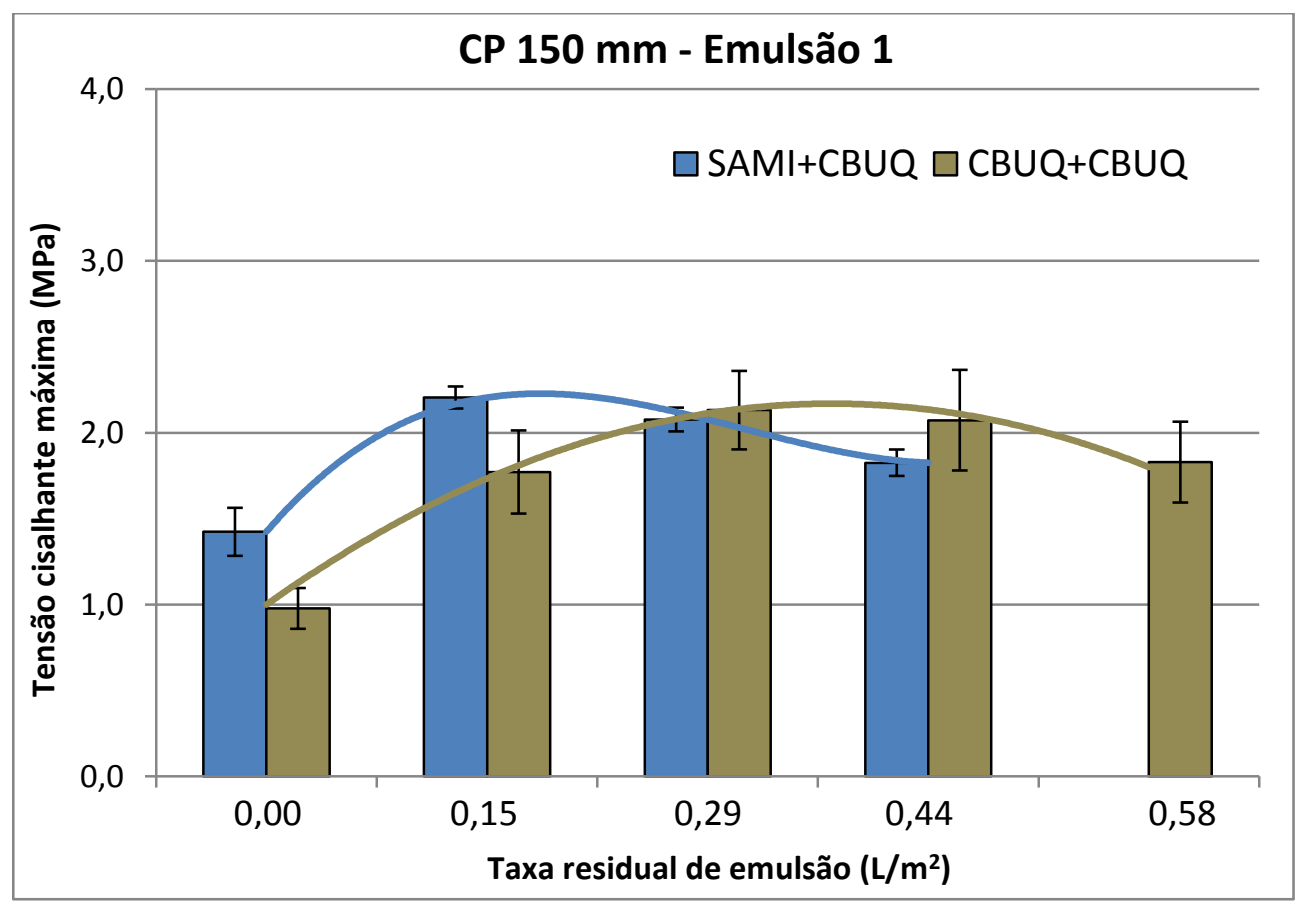

Figura 4.18 - Tensão cisalhante versus taxa de aplicação da pintura de ligação para diferentes texturas superficiais entre camadas (CP $150 \mathrm{~mm}$ ) 


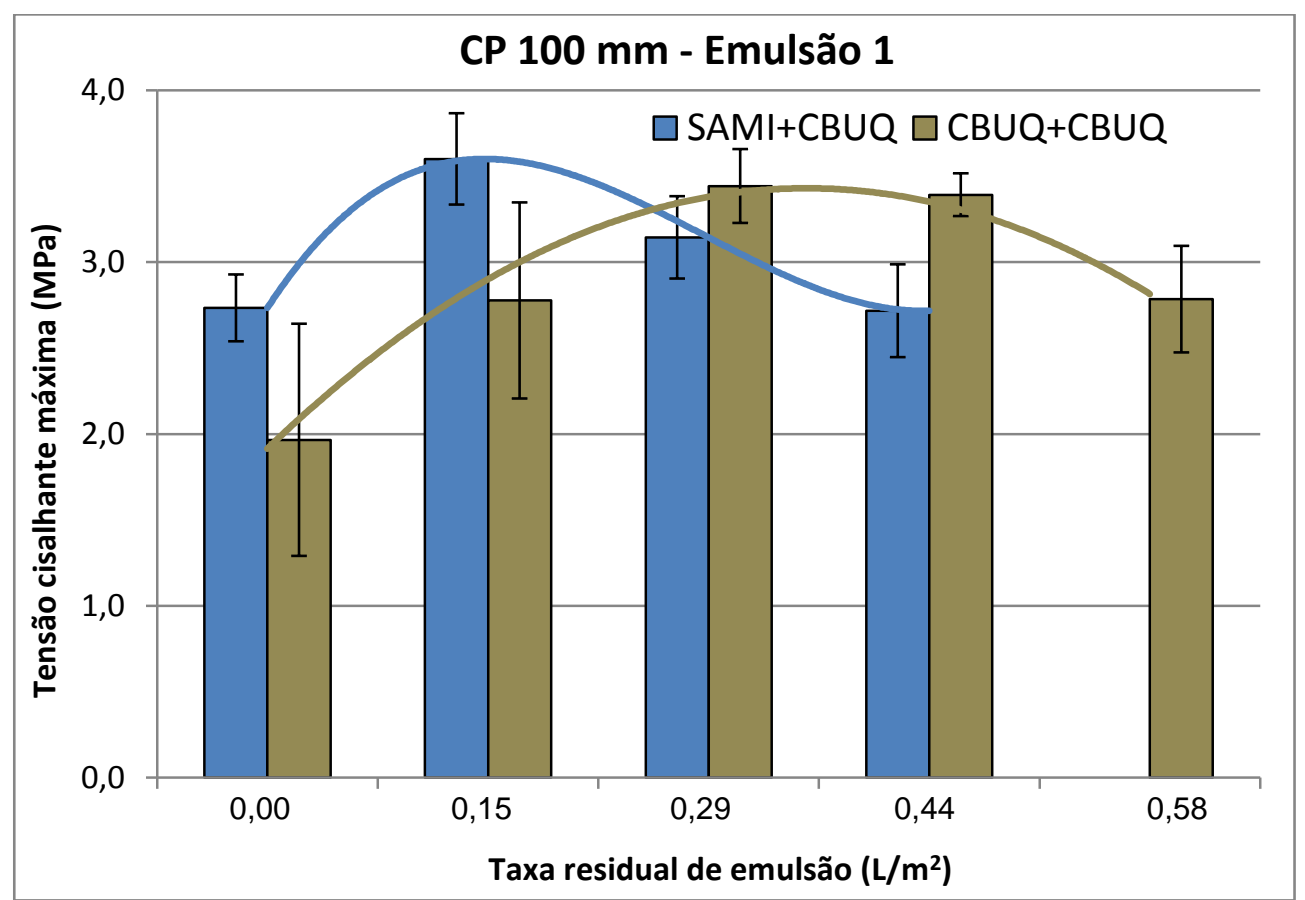

Figura 4.19 - Tensão cisalhante versus taxa de aplicação da pintura de ligação para diferentes texturas superficiais entre camadas (CP $100 \mathrm{~mm}$ )

Para os dois tamanhos de amostra, a macrotextura da superfície das misturas asfálticas mostrou ter influência direta no valor de resistência ao cisalhamento. Os resultados com amostras de CBUQ-CBUQ, que possuem duas superfícies rugosas em contato ( $C B \cup Q$ com $\mathrm{HS}=0,89$ no ensaio de mancha de areia apresentado no Capítulo 3) correspondem a valores um pouco maiores para tensão máxima e taxa de aplicação de pintura. Para o caso de SAMI-CBUQ, o SAMI por ser uma mistura fina apresenta valor mais baixo de macrotextura $(\mathrm{HS}=0,66)$, além de um maior percentual de ligante asfáltico na mistura, o que deve ter contribuído para uma taxa ótima inferior de emulsão asfáltica. No estudo realizado por Raposeiras et al. (2012), os autores observaram que para misturas asfálticas com valores mínimos de macrotextura, a taxa ótima de pintura de ligação estaria abaixo do exigido pela especificação espanhola $\left(0,25 \mathrm{~L} / \mathrm{m}^{2}\right)$. O efeito da rugosidade da superfície na resistência ao cisalhamento na interface também foi investigado por Mohammad et al. (2010). Os autores acharam uma correlação direta entre os dois parâmetros quando compararam superfícies fresadas com superfícies não fresadas, onde a primeira levou a valores de resistência ao cisalhamento superiores, independente do tipo de pintura de ligação utilizada. 


\subsection{MÓDULO DE REAÇÃO NA INTERFACE}

Conforme descrito no Capítulo 2, o módulo de reação na interface $(K)$ é definido pela inclinação do gráfico de tensão versus deslocamento, da origem até o ponto de tensão cisalhante máxima. Por ser um importante parâmetro de entrada para modelagem estrutural de problemas de cisalhamento na interface, avaliou-se a inclinação da curva de tensão para cada caso discutido anteriormente: (i) o efeito do tipo de emulsão, (ii) da velocidade de ensaio, (iii) da textura superficial das camadas, (iv) da presença ou não de geotêxtil/grelha e (v) do tamanho da amostra. Os resultados estão apresentados nos gráficos das Figuras 4.20 a 4.23 abaixo.

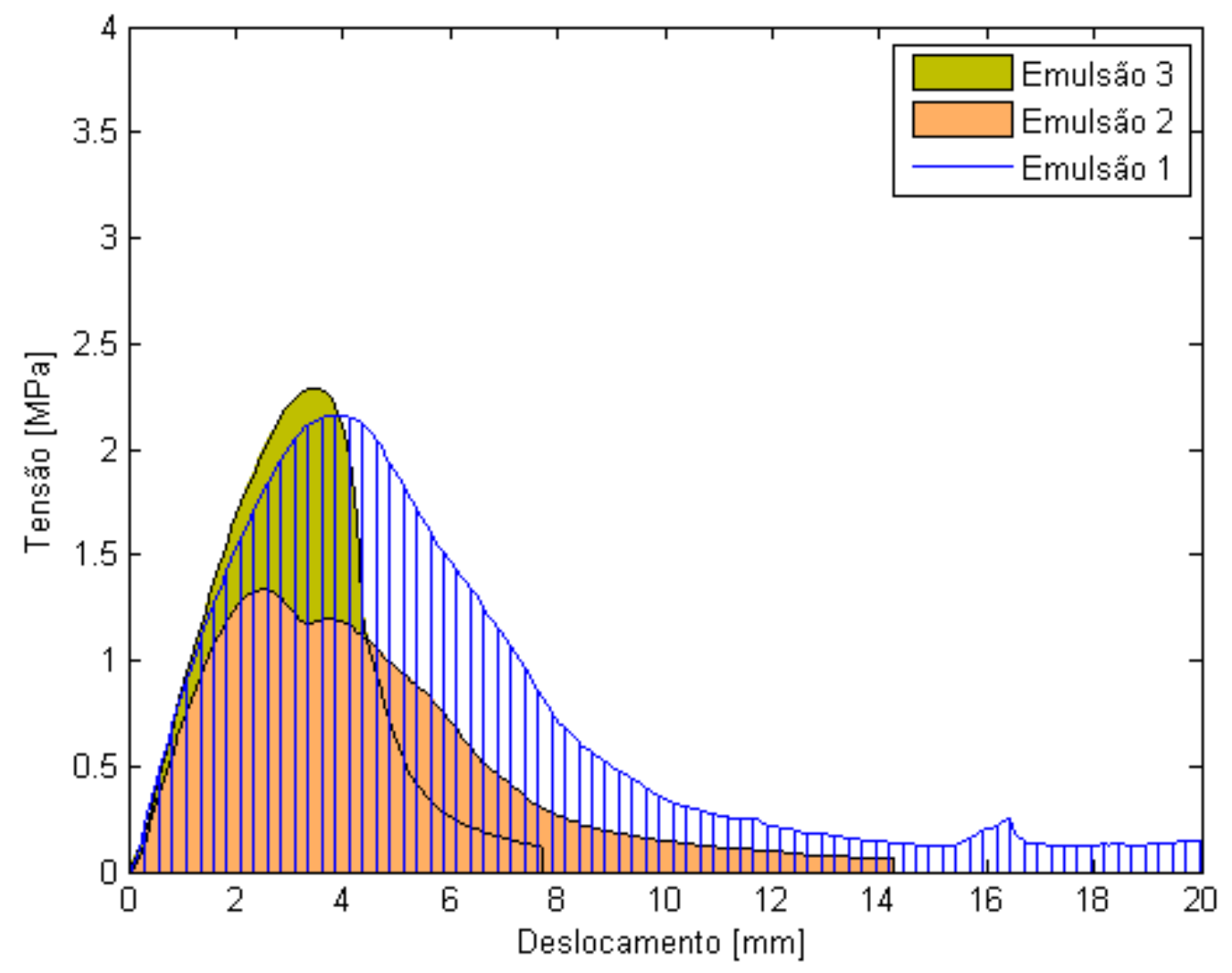

(a) 


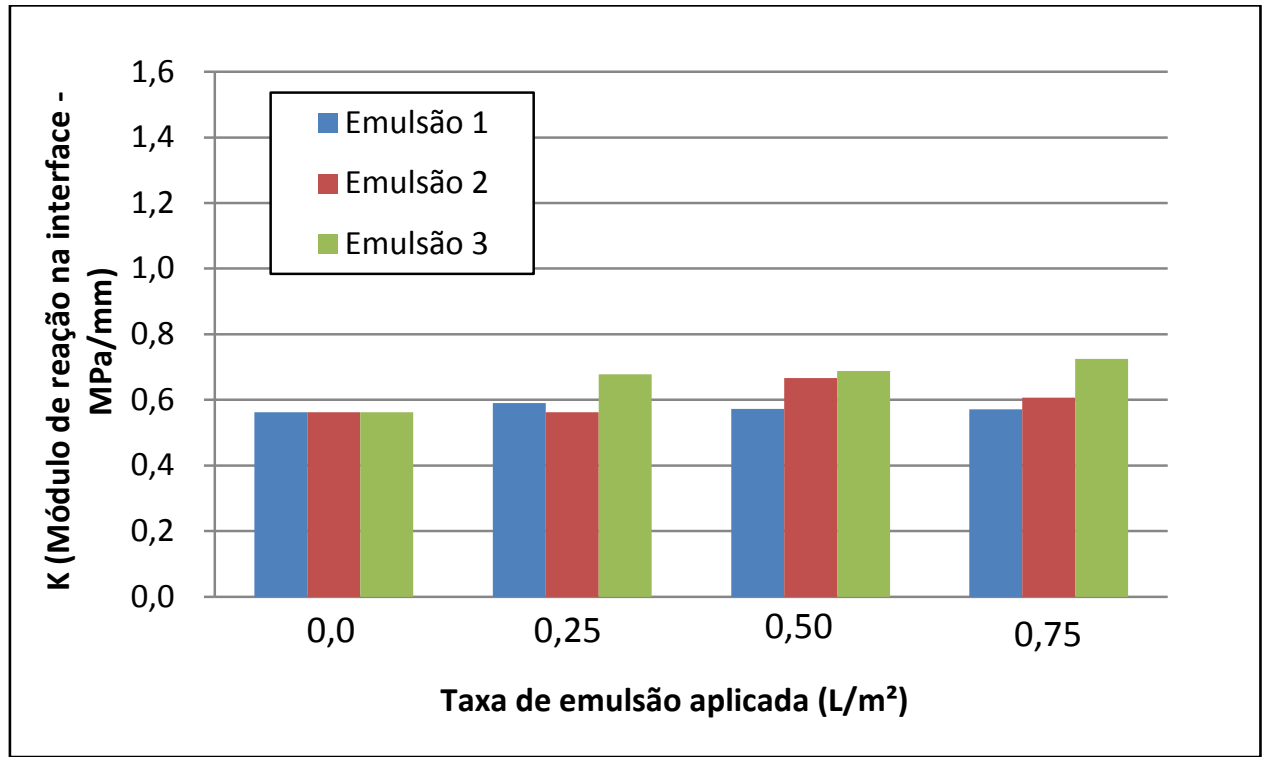

(b)

Figura 4.20 - (a) Gráficos de tensão cisalhante máxima versus deslocamento e (b) módulo de reação na interface para amostras Emulsão 1, 2 e 3 (CP 150 mm)

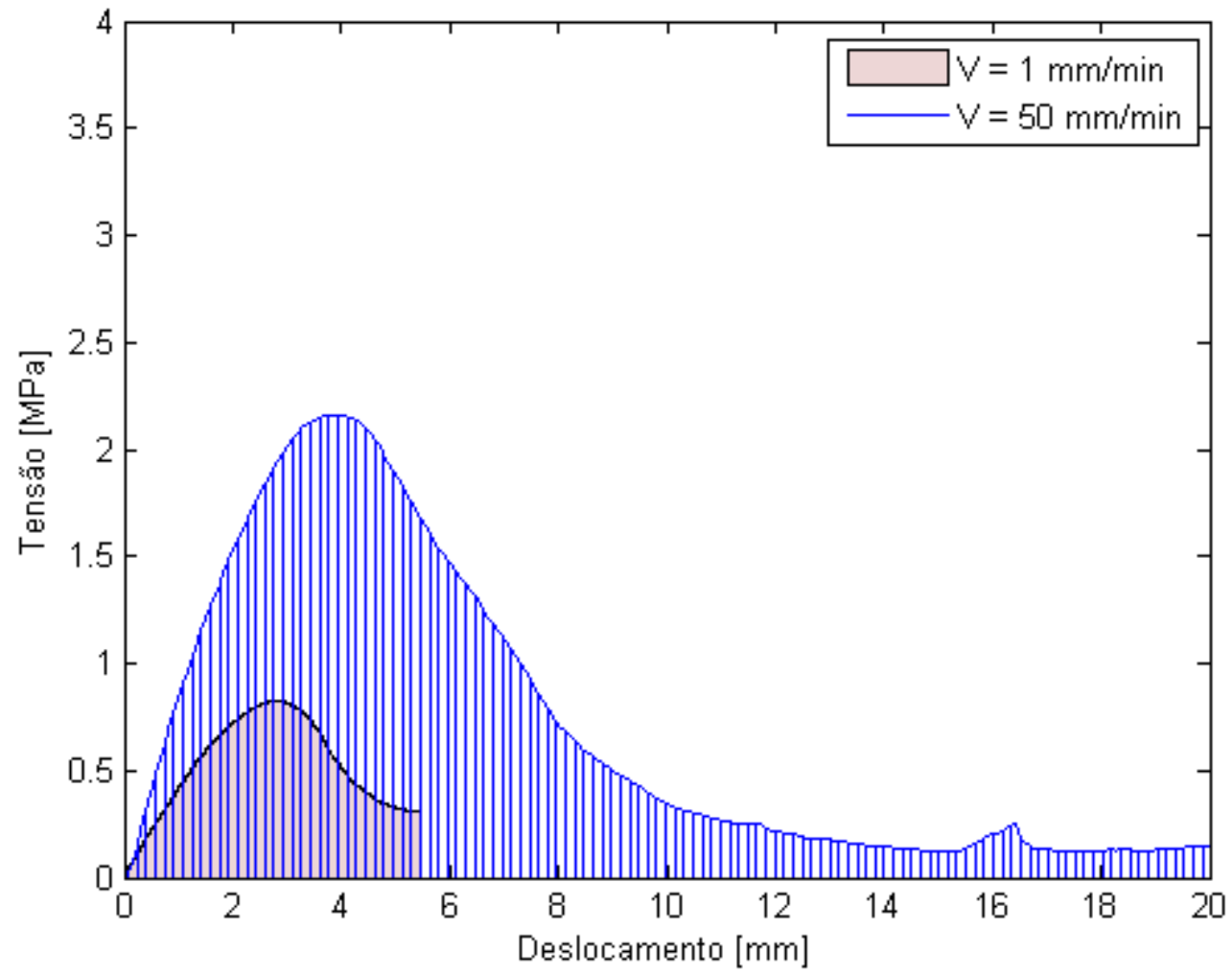

(a) 


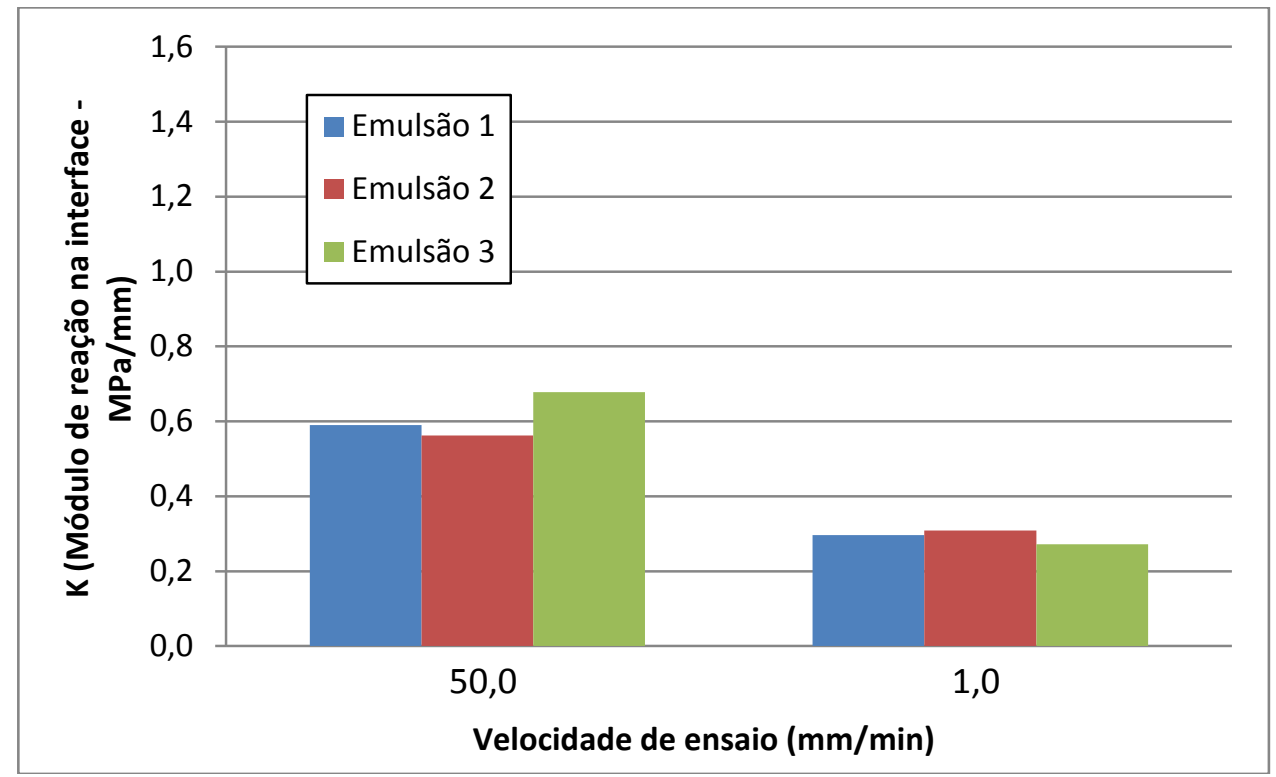

(b)

Figura 4.21 - (a) Gráficos de tensão cisalhante máxima versus deslocamento e (b) módulo de reação na interface para diferentes velocidades de ensaio

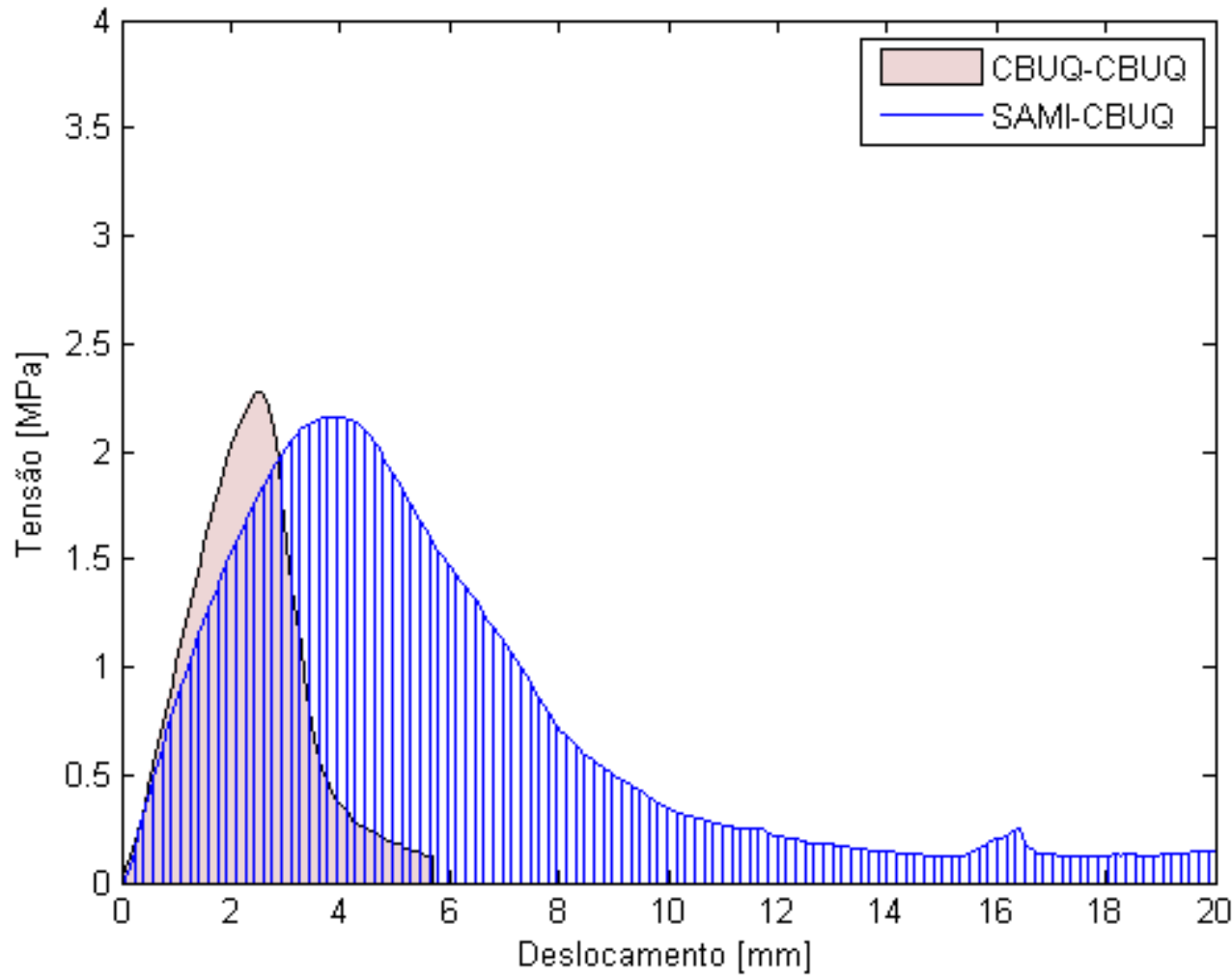

(a) 


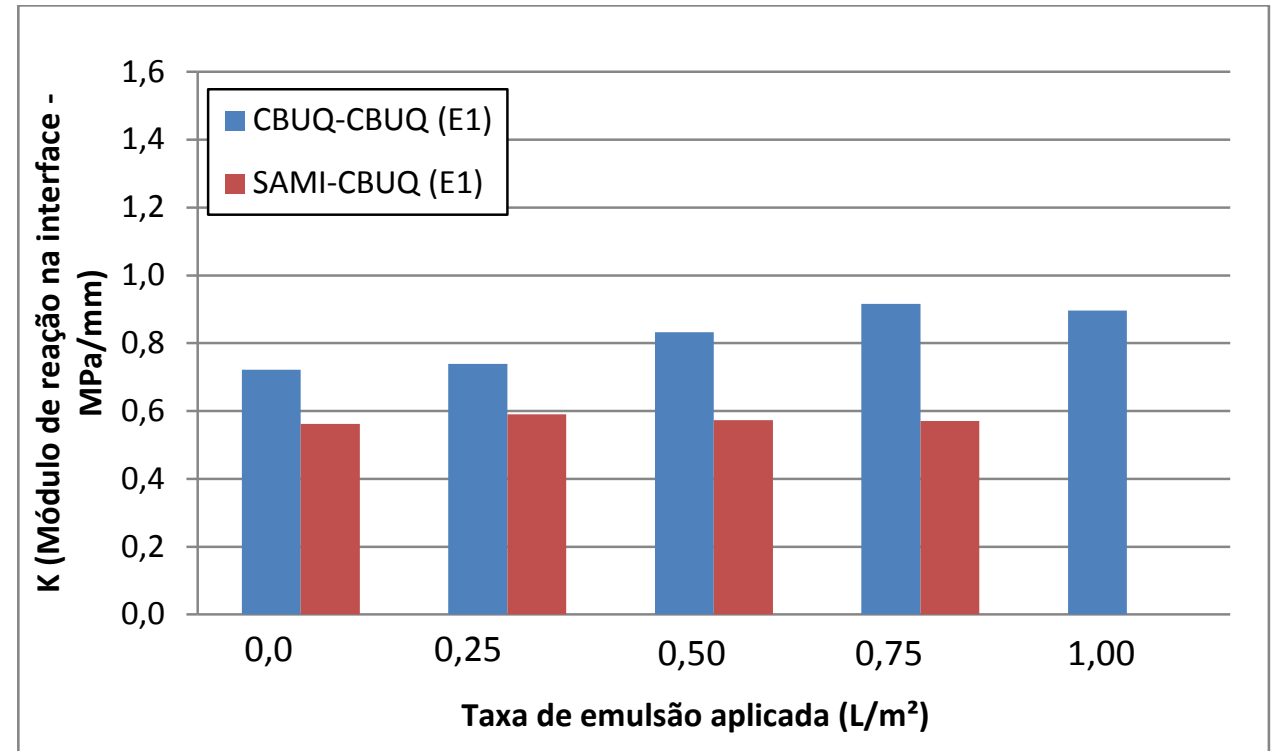

(b)

Figura 4.22 - (a) Gráficos de tensão cisalhante máxima versus deslocamento e (b) módulo de reação na interface para amostras com diferentes texturas superficiais (CP $150 \mathrm{~mm}$ )

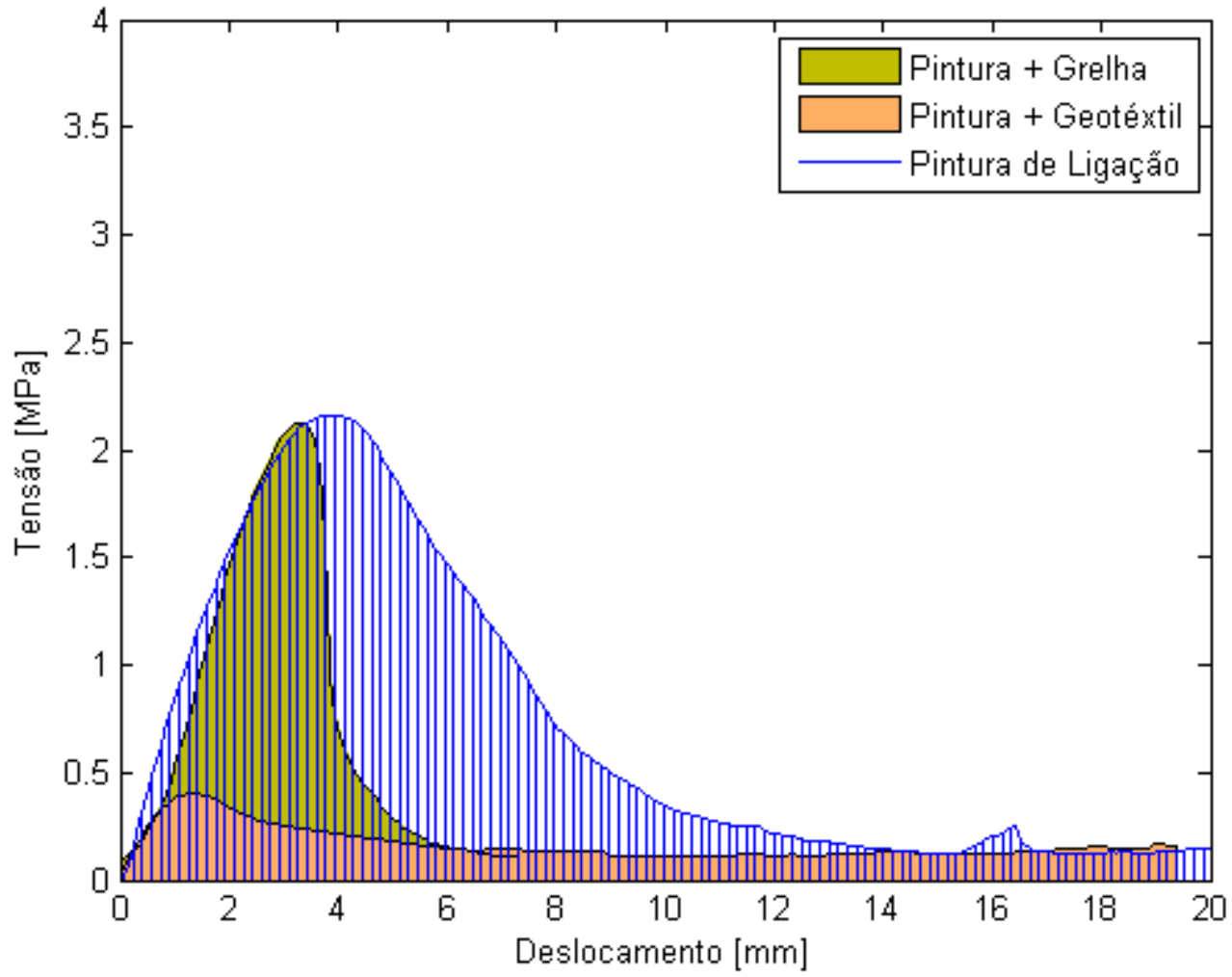

(a) 


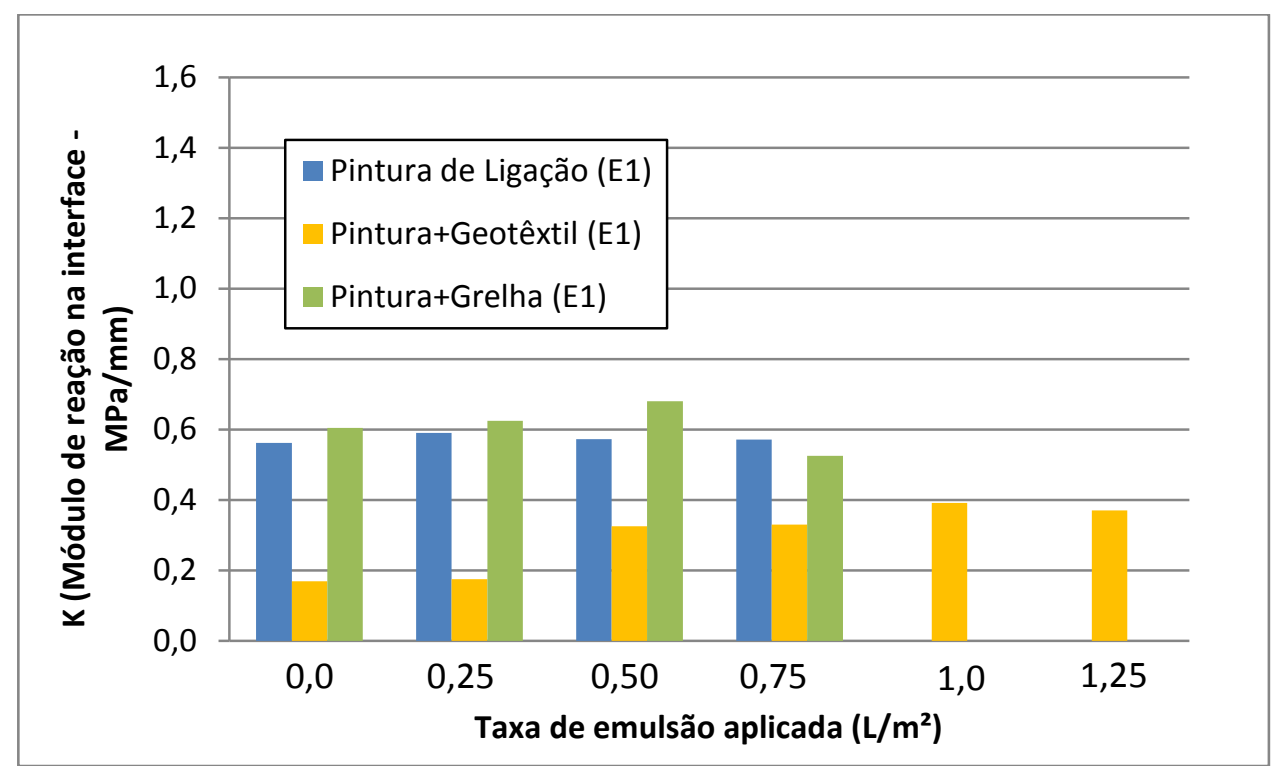

(b)

Figura 4.23 - (a) Gráficos de tensão cisalhante máxima versus deslocamento e (b) módulo de reação na interface para amostras com presença ou não de geotêxtil/grelha (CP $150 \mathrm{~mm}$ )

Percebe-se, da Figura 4.20 que, apesar de apresentarem valores de tensões cisalhantes máximas diferentes, as três emulsões analisadas não apresentam diferença signifcativa entre si para o resultado da inclinação das curvas de tensão versus deslocamento. A taxa de emulsão também não influenciou os valores de $\mathrm{K}$ para nenhuma das três emulsões avaliadas. A análise das inclinações nas curvas resultantes do ensaio às velocidades de $1,0 \mathrm{~mm} / \mathrm{min}$ e $50,0 \mathrm{~mm} / \mathrm{min}$ apresentou diferença no módulo de reação (Figura 4.21), sendo K maior para velocidade maior. Para as diferentes texturas superficiais (análise de CBUQ-CBUQ e SAMI-CBUQ), o gráfico do valor de inclinação (módulo de reação na interface), da Figura 4.22, apresenta maiores valores para a superfície com maior macrotextura (CBUQCBUQ). Na Figura 4.23 percebe-se que os valores $\mathrm{K}$ são semelhantes para amostras somente com pintura de ligação e amostras com grelha+pintura. As amostras com presença de geotêxtil apresentaram valores bem menores quando comparados às outras soluções na interface. Em última análise, entre diferentes tamanhos de amostras, apresentada na Figura 4.24, confirmam-se os valores de inclinação diferentes, indicados anteriormente no gráfico de tensão versus deslocamento da Figura 4.12. 


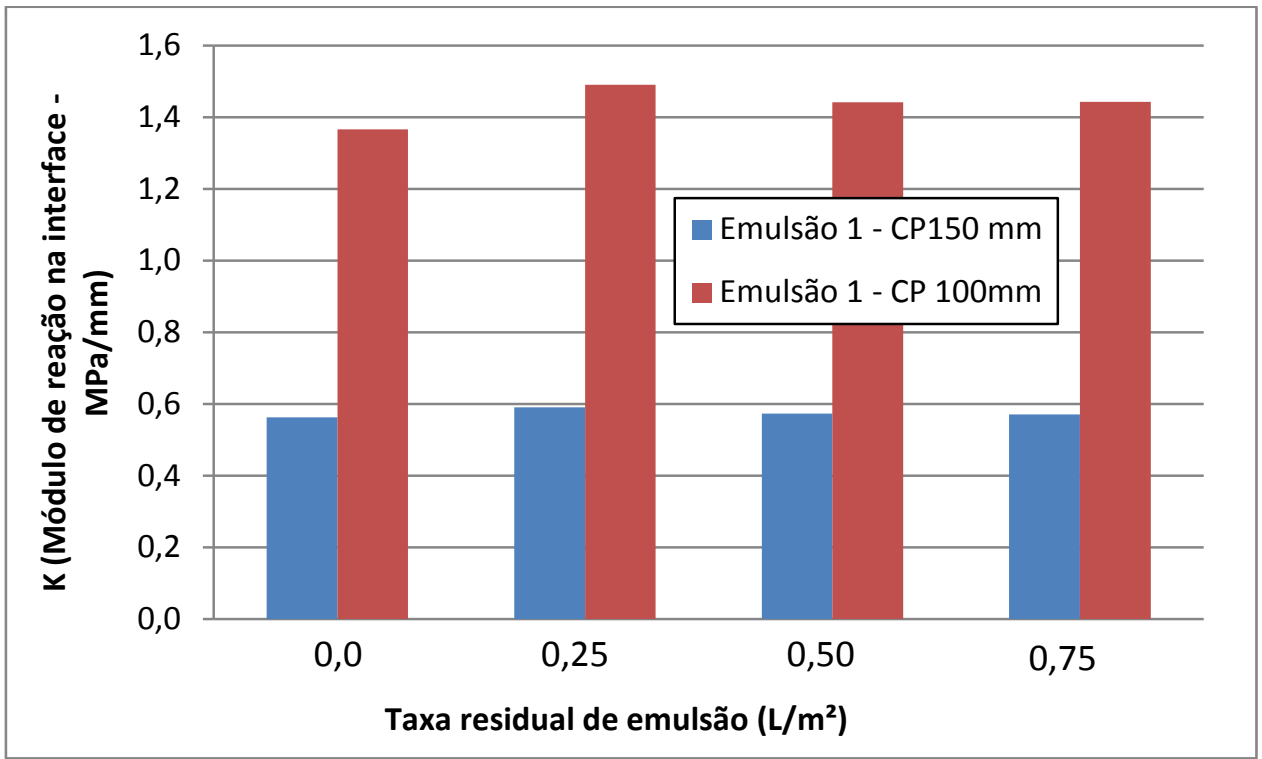

Figura 4.24 - Módulo de reação na interface para amostras com 150 e 100 mm de diâmetro 


\section{TRECHO EXPERIMENTAL}

A rodovia Ayrton Senna (SP-070), construída em 1982, interliga a capital de São Paulo à cidade de Guararema, na região do Alto Tietê. Desde 2009, está sob concessão da empresa Ecopistas, pertencente ao grupo Ecorodovias. A rodovia tem início na divisa entre São Paulo e Guarulhos, no Parque Ecológico do Tietê, e termina no km 61,300, onde inicia a Rodovia Carvalho Pinto (também SP-070). Esta última termina em Taubaté, no km 130,400, onde faz interseção com a Rodovia Presidente Dutra (BR-116). O sistema Ayrton Senna - Carvalho Pinto, com intenso tráfego de veículos, configura importante corredor para o escoamento de produção, além de interligação entre São Paulo, Litoral Norte, Campos do Jordão e Rio de Janeiro. Possui pista dupla em toda a sua extensão, com 2, 3 ou 4 faixas de rolamento, e três praças de pedágio: em Itaquaquecetuba (km 32), Guararema (km 59) e São José dos Campos (km 93).

Inserido na programação de intervenções para restauração de toda a Rodovia Ayrton Senna, o trecho experimental em estudo foi executado com $1500 \mathrm{~m}$. Está localizado entre os km 38,000 e 39,500 da Pista Leste (sentido Capital-Interior), na Faixa 2, das 3 faixas de rolamento existentes, conforme Figura 5.1 a seguir.

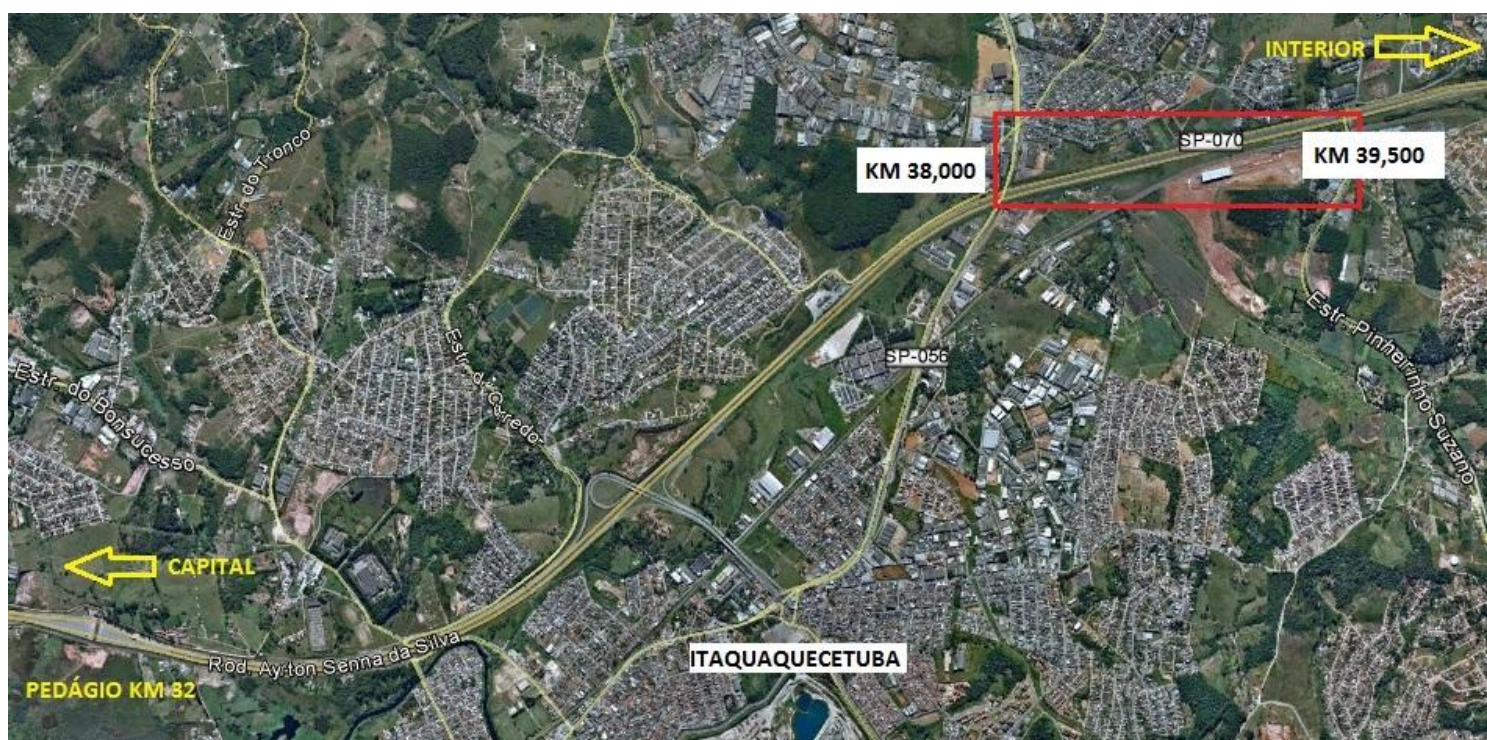

Figura 5.1 - Mapa de localização do trecho experimental. Adaptado de www.maps.google.com 


\subsection{CARACTERIZAÇÃO DO TRECHO EXPERIMENTAL}

\subsubsection{Escolha do Trecho Experimental}

A escolha do trecho experimental, do $\mathrm{km} \mathrm{38,000}$ ao $\mathrm{km} \mathrm{39,500}$ da Rodovia Ayrton Senna, foi baseada nas condições superficiais, funcionais e estruturais do pavimento existente. A partir de levantamento deflectométrico ao longo de toda a rodovia (com equipamento Falling Weight Deflectometer - FWD, em abril de 2010), procurou-se definir um segmento homogêneo, com valores baixos de deflexão. Ao mesmo tempo, com ajuda de vídeo filmagem realizada em fevereiro de 2012 para levantamento das condições funcionais do pavimento existente, verificou-se a situação atual de alto trincamento no segmento escolhido. Os baixos valores de deflexão e o elevado trincamento confirmariam a hipótese de falha no revestimento asfáltico e não na base ou fundação do pavimento.

A Figura 5.2 traz o levantamento estrutural de deflexões da rodovia em abril de 2010, e a Figura 5.3, o levantamento dos defeitos superficiais, realizado em fevereiro de 2012. No segmento escolhido, as deflexões encontravam-se com valores baixos, apresentando média de $16,1 \times 10^{-2} \mathrm{~mm}$ e desvio padrão de 4,1 $(0,01 \mathrm{~mm})$. O levantamento de defeitos na superfície (Figura 5.3) apontou a existência de trincas (fissuras) isoladas, do tipo longitudinais longas e trincas interligadas em bloco. $\mathrm{O}$ revestimento estava desgastado em todo o trecho e alguns remendos pontuais e afundamentos na trilha de roda também foram detectados. Na Figura 5.3, cada quadrado equivale a $50 \mathrm{~m}$ e o número indicado é o comprimento detectado com o defeito.

O levantamento com o FWD foi feito a cada $80 \mathrm{~m}$, com carga média de $4,1 \mathrm{t}$ aplicada no $D_{0}$. A contagem de defeitos foi realizada com o equipamento de vídeo filmagem a uma velocidade de aproximadamente $50 \mathrm{~km} / \mathrm{h}$ e, está apresentada a cada $50 \mathrm{~m}$. 


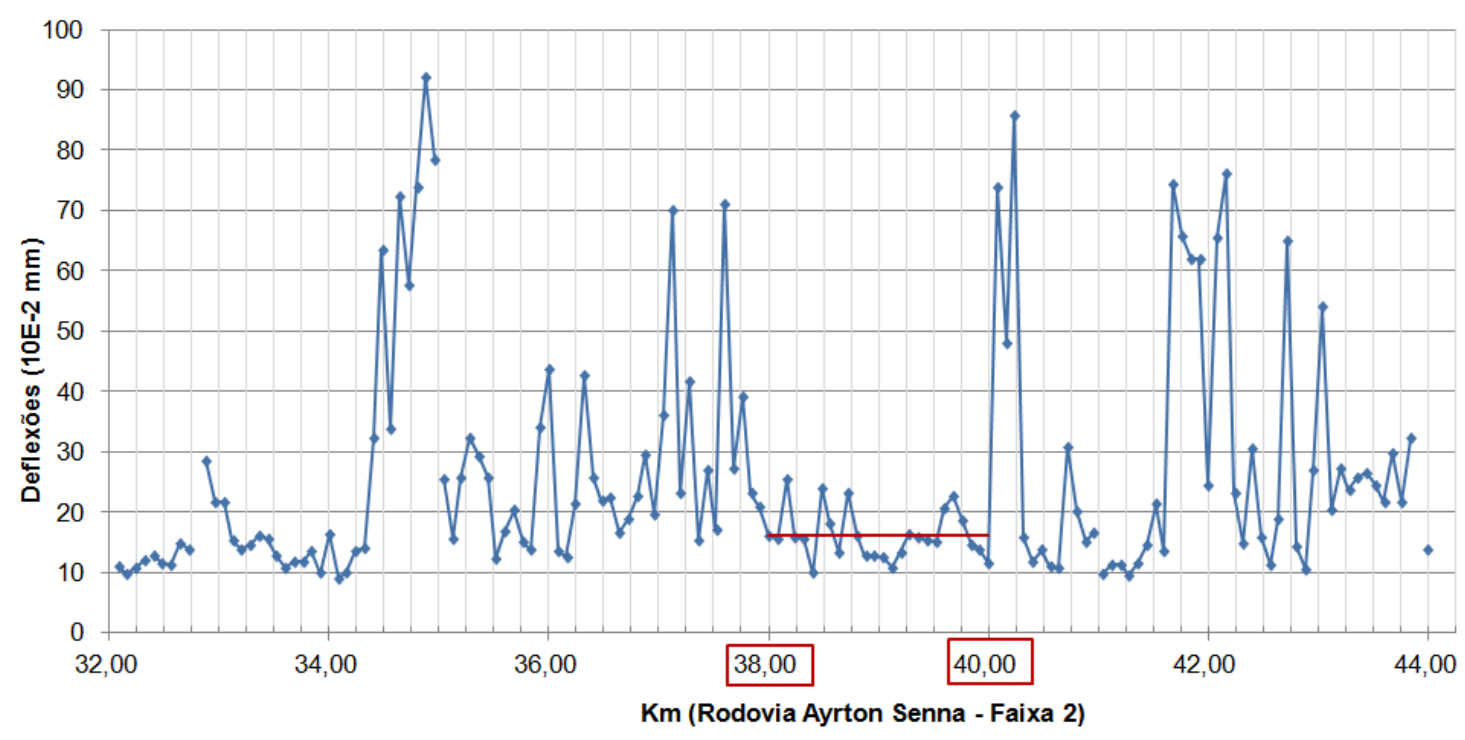

Figura 5.2 - Levantamento deflectométrico FWD com carga de 4,1 t (abril de 2010)

Fissura CR

Fissura Bloco

Afundamento Longitudinal

Desgaste

Remendo Pontual

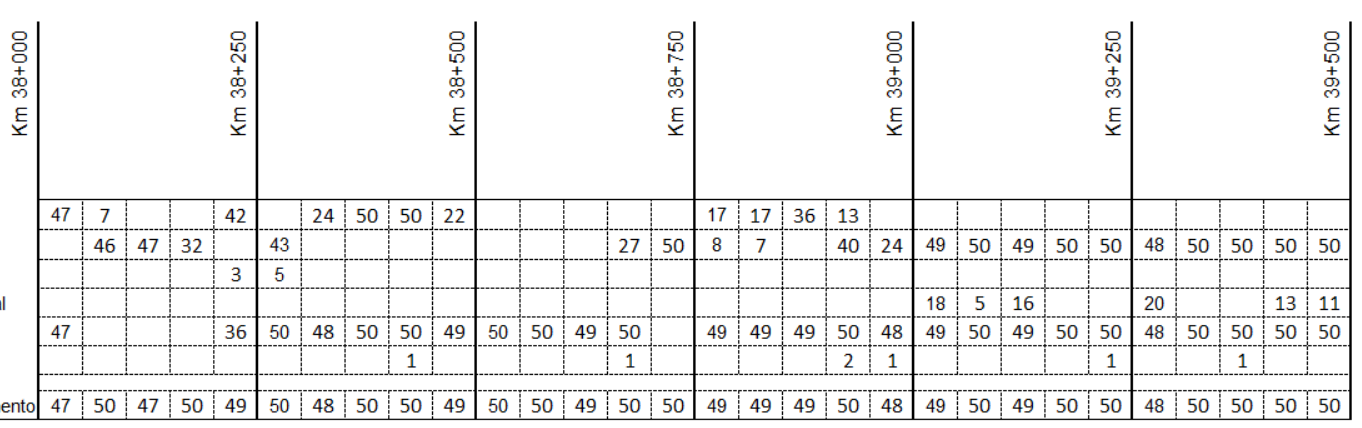

Figura 5.3 - Levantamento de defeitos no pavimento do trecho experimental (fevereiro de 2012)

\subsubsection{Estrutura do Pavimento Existente}

A estrutura de pavimento existente na região do trecho experimental foi estimada com base no perfil do poço de inspeção de pavimento aberto em junho de 2012, no km 38,000 da Pista Leste (Figura 5.4). A sondagem foi executada na faixa 3 e as camadas de pavimento estão representadas na Figura 5.5 a seguir. 


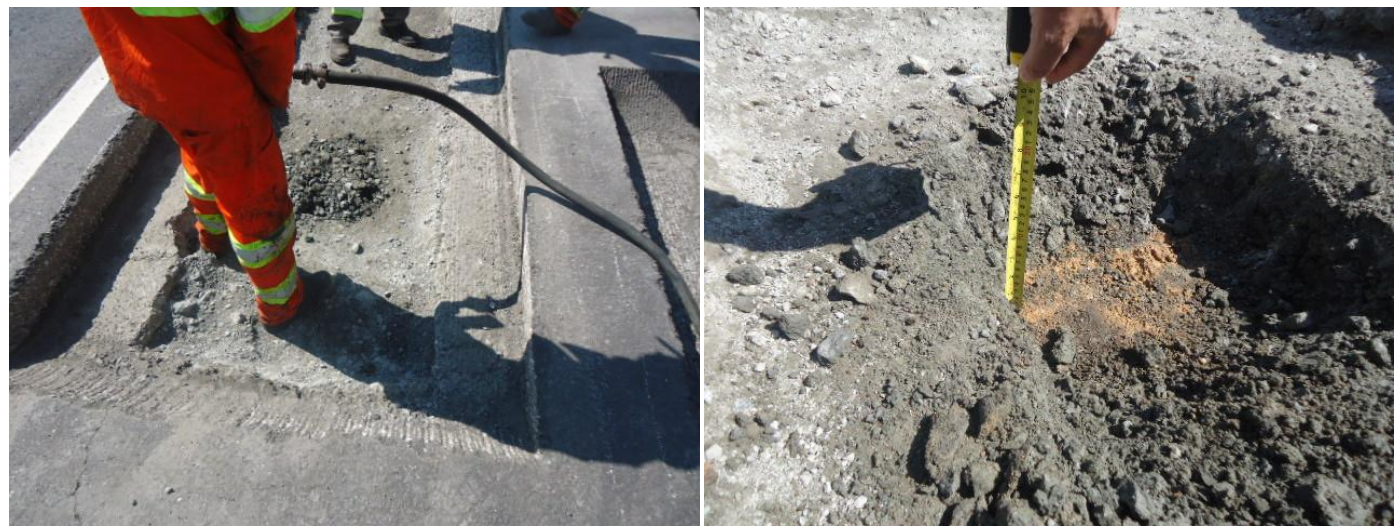

Figura 5.4 - Execução de poço de inspeção de pavimento

\begin{tabular}{cc} 
Faixa 3 - Pista Leste - $\mathbf{k m} \mathbf{3 8}$ & Espessura (cm) \\
\hline CBUQ (Concreto Betuminoso Usinado a Quente) & 10,0 \\
\hline PMF (Pré-Misturado a Frio) & 10,0 \\
\hline Brita Graduada Tratada com Cimento (BGTC) & 12,0 \\
\hline Brita Graduada Simples (BGS) & 15,0 \\
\hline Subleito Argiloso & -
\end{tabular}

Figura 5.5 - Camadas do pavimento existente (Poço de inspeção $\mathrm{km} \mathrm{38}$, fornecido pela concessionária Ecopistas)

\subsection{SOLUÇÕES DE RESTAURAÇÃO PARA O TRECHO EXPERIMENTAL}

O projeto original de restauração da Faixa 2 da Ayrton Senna prevê solução com fresagem de $6,0 \mathrm{~cm}$ e recomposição com $7,0 \mathrm{~cm}$ de revestimento asfáltico. A camada de recomposição é dividida em uma camada asfáltica anti-reflexão de trincas tipo SAMI com 2,0 cm e uma camada de CBUQ com 5,0 cm de espessura. Para avaliar o desempenho e, principalmente, a influência do uso de diferentes tipos de tratamento anti-reflexão de trincas na aderência, este estudo indicou ainda a aplicação de outras cinco configurações para o trecho experimental. A obra foi executada em dois domingos consecutivos (18 e 25 de março de 2012) das 7:00 às 17:00, horário no qual o tráfego, menos intenso, permitia o fechamento da pista durante o dia. Ao total, as seis seções-teste executadas, e numeradas posteriormente de acordo com a ordem de execução, são descritas abaixo e representadas na Figura 5.6 a seguir. 
a) Seções executadas em 18/03/2012:

- Trecho 1 (T1) - 248 m do km 38+745 ao km 38+993: Aplicação de SAMI+CBUQ (solução adotada para o restante da Rodovia em questão e tomada, portanto, como referência);

- Trecho 2 (T2) - 259 m do km 38+993 ao km 39+252: Aplicação de SAMI+CBUQ com uso de geotêxtil não tecido agulhado de poliéster na interface;

- Trecho 3 (T3) - 179 m do km 39+252 ao km 39+431: Aplicação de CBUQ (sem o SAMI) e geotêxtil na interface com a infraestrutura remanescente.

b) Seções executadas em 25/03/2012:

- Trecho 4 (T4) - 250 m do km 38+017 ao km 38+267: Aplicação de $\mathrm{SAMI}+\mathrm{CBUQ}$ com uso de grelha de fibra de vidro na interface entre SAMI e $C B \cup Q$;

- Trecho 5 (T5) - 250 m do km 38+267 ao km 38+517: Aplicação de CBUQ (sem o SAMI) e grelha de fibra de vidro na interface com a infraestrutura remanescente;

- Trecho 6 (T6) - 259 m do km 38+517 ao km 38+740: Aplicação de CBUQ (sem o SAMI) apenas com pintura de ligação na interface com a infraestrutura remanescente.

Os materiais empregados em campo são os mesmos utilizados para o desenvolvimento da pesquisa em laboratório e estão, portanto, caracterizados no Capítulo 3. A Pedreira Santa Isabel (PSI), local onde foram produzidas as misturas asfálticas de SAMI e CBUQ, está a aproximadamente uma distância de $30 \mathrm{~km}$ do trecho experimental, conforme Figura 5.6 a seguir. 


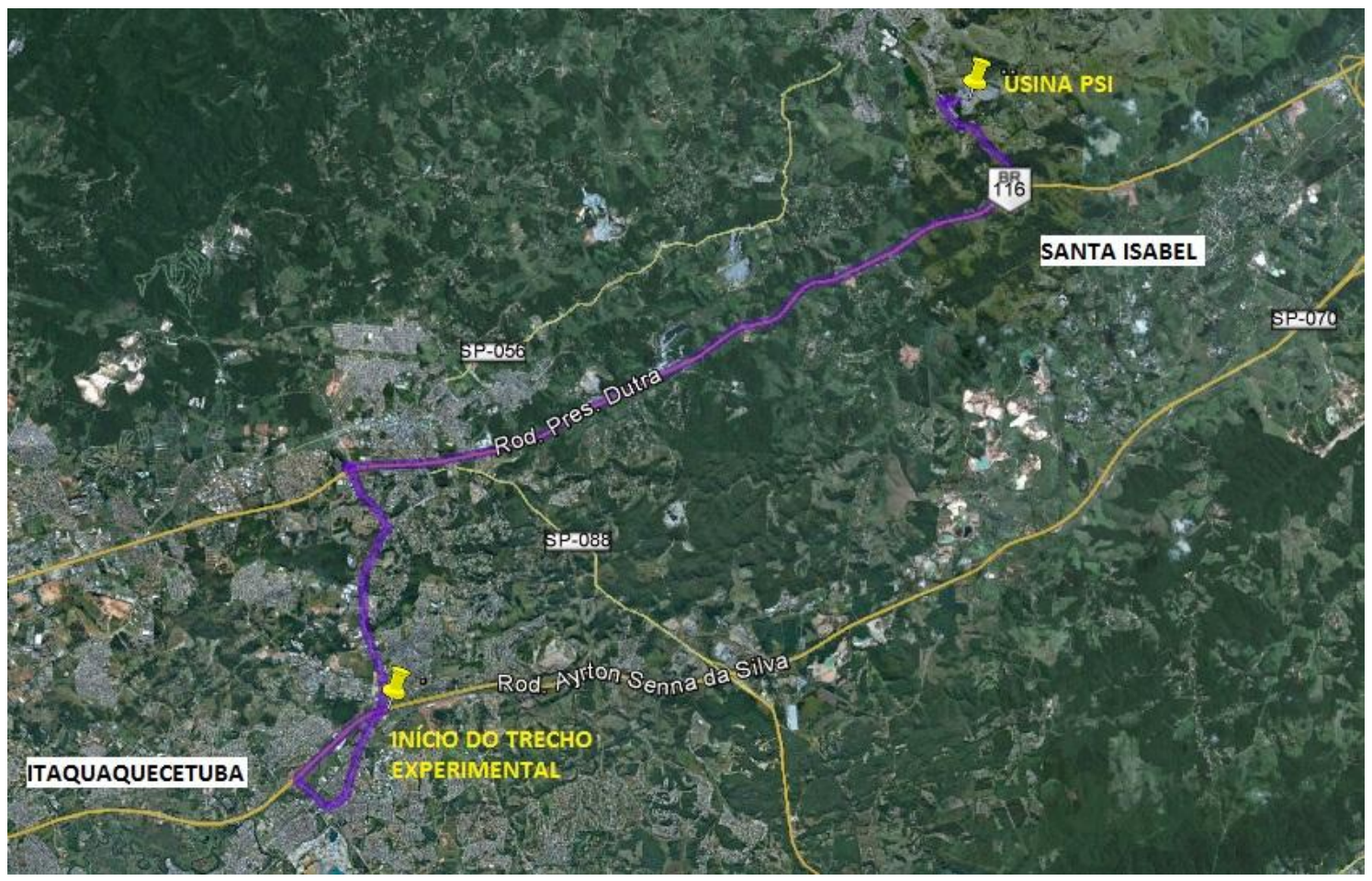

Figura 5.6 - Distância entre a Usina PSI e o Trecho Experimental. Adaptado de www.maps.google.com

As temperaturas de saída da usina e de chegada na obra foram controladas para garantir que não houve perda significativa durante o transporte. Os valores de temperatura, tanto de aplicação quanto de chegada ao campo de cada caminhão, variaram de 160 a $170^{\circ} \mathrm{C}$. Ao total, quatro caminhões de SAMI e dezesseis caminhões de CBUQ foram utilizados na obra do dia 18/03/2012. No dia 25/03/2012 foram utilizados dois caminhões de SAMI e dezoito caminhões de CBUQ.

Nas seções executadas em 18/03/2012 (trechos T1, T2 e T3) aplicou-se, como pintura de ligação, emulsão RR-1C, catiônica convencional de ruptura rápida, mesma Emulsão 1 utilizada para confecção das placas em laboratório e descrita no Capítulo 3. No dia 25/03 (trechos T4, T5 e T6), aplicou-se emulsão RR-1C-E, catiônica de ruptura rápida modificada por polímero SBR, também utilizada na pesquisa em laboratório como Emulsão 2. Na obra, a Emulsão 1 foi utilizada com um recorte de 30\%, enquanto a Emulsão 2 foi aplicada sem recorte, conforme informações fornecidas pela equipe de execução. Em ambos os casos, a pintura de ligação foi aplicada entre todas as camadas desde a infraestrutura remanescente.

A princípio, os seis segmentos seriam executados com $250 \mathrm{~m}$. A existência de faixas com laço indutivo detector do radar eletrônico sob o pavimento, no encontro 


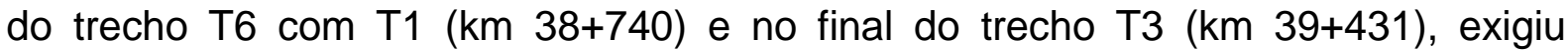
comprimentos um pouco menores.

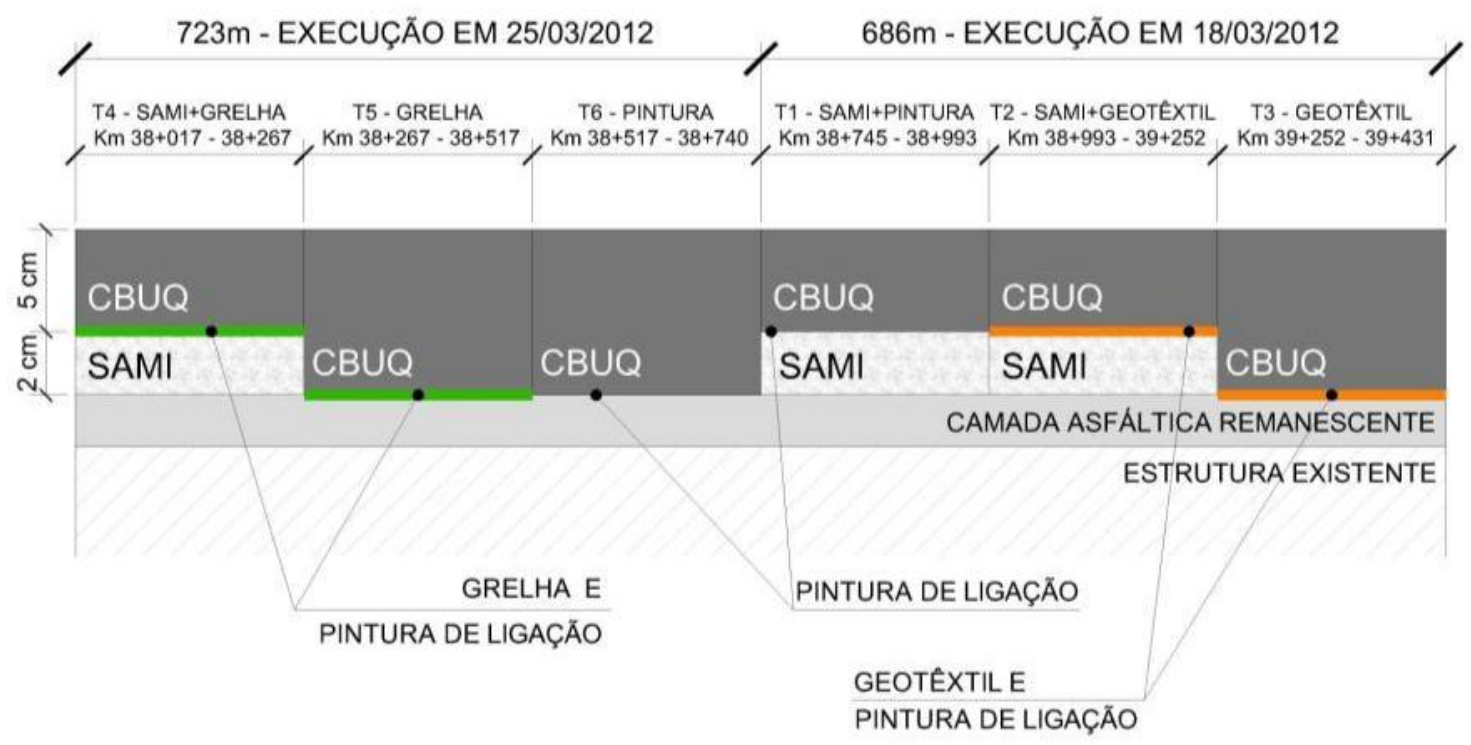

Figura 5. 7 - Esquema com as seções-teste do trecho experimental

\subsection{EXECUÇÃO DO TRECHO EXPERIMENTAL}

A sequência de execução dos serviços para cada dia de obra (18 e 25 de março) segue apresentada, respectivamente, nos itens 5.3.1 (Figuras 5.10 a 5.31) e 5.3.2 (Figuras 5.32 a 5.51).

Nos dois dias, realizou-se levantamento deflectométrico com equipamento FWD antes e após fresagem da camada asfáltica. Na caixa fresada o levantamento também foi realizado com LWD (Light Weight Deflectometer), para posterior comparação de resultados (Figuras 5.8 e 5.9). 


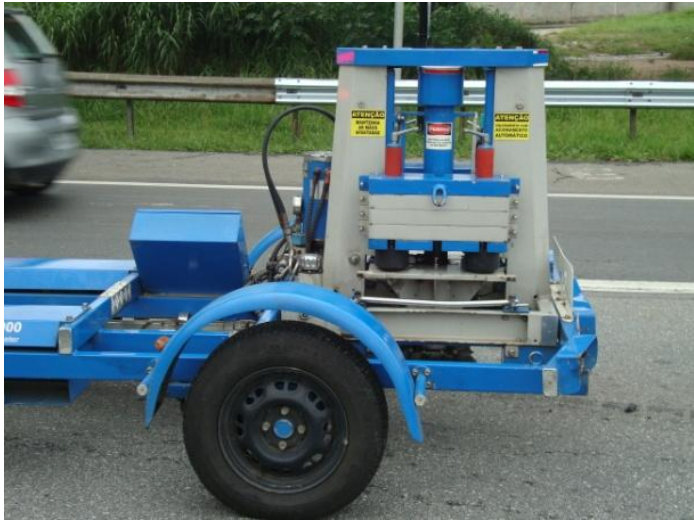

Figura 5. 8 - Levantamento FWD antes do início da obra

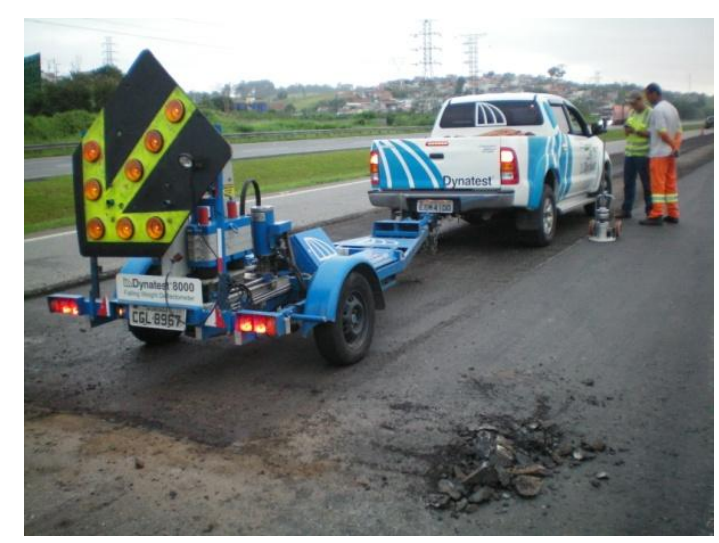

Figura 5. 9 - Levantamento FWD e LWD na caixa fresada

\subsubsection{Execução dos trechos T1, T2 e T3}

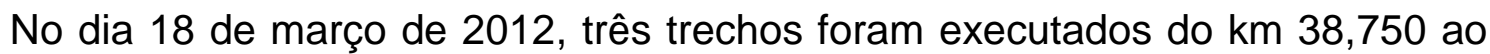
39,500, denominados T1 (SAMI+CBUQ com pintura de ligação na interface), T2 (SAMI+CBUQ com geotêxtil na interface) e T3 (CBUQ sobre camada fresada com geotêxtil na interface). Abaixo segue a sequência de execução dos três segmentos do dia 18/03/2012, com utilização da Emulsão 1 (RR-1C).

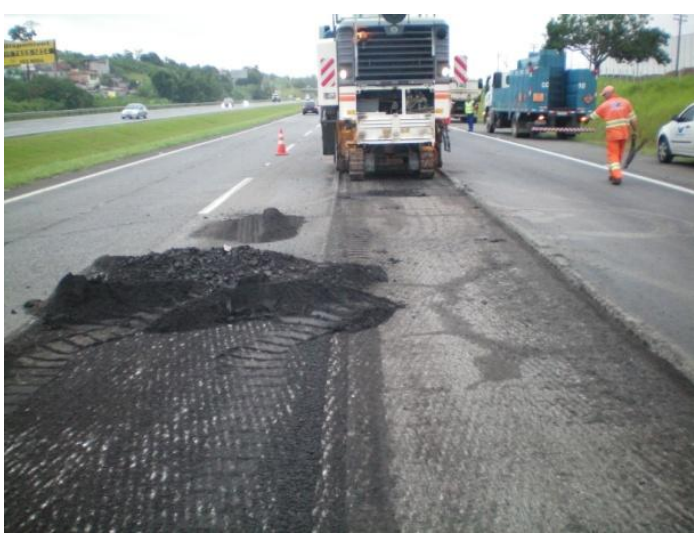

Figura 5. 10 - Fresagem de $6,0 \mathrm{~cm}$ da camada asfáltica antiga

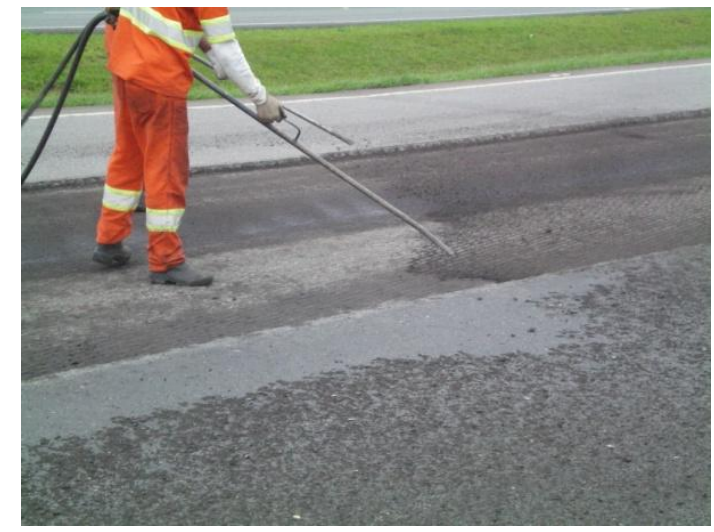

Figura 5. 11 - Limpeza com ar comprimido da superfície após fresagem 


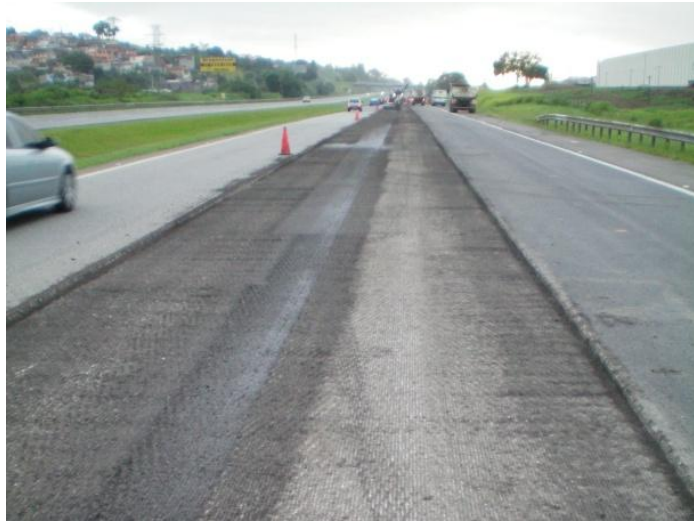

Figura 5. 12 - Caixa Fresada

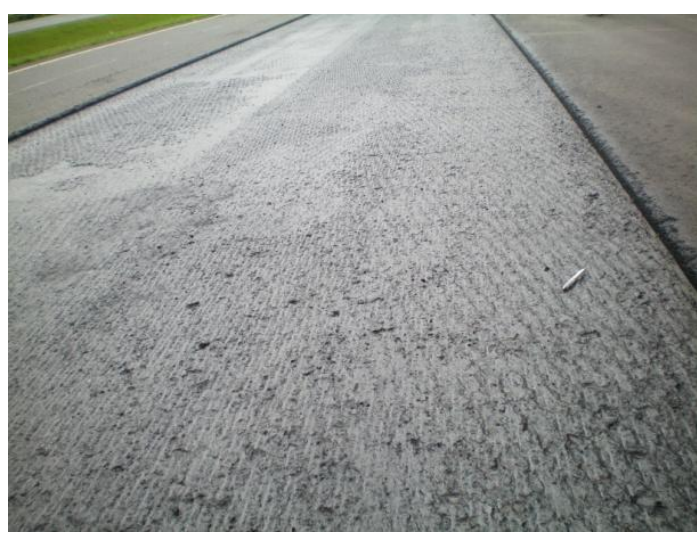

Figura 5. 14 - Pintura de ligação aplicada sobre a superfície fresada (1)

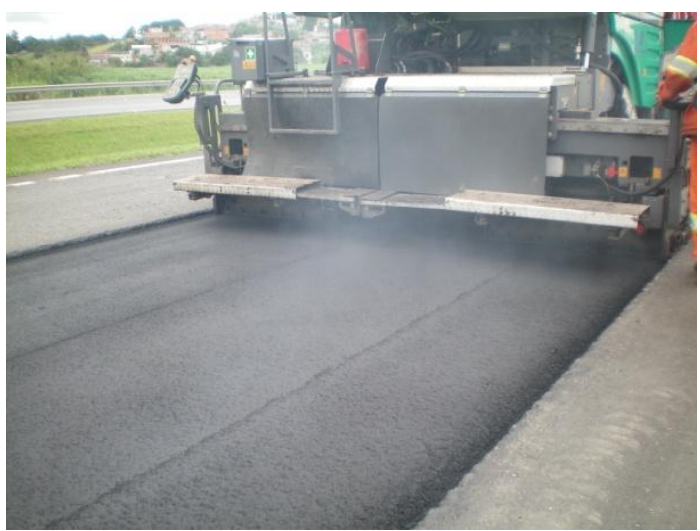

Figura 5. 16 - Execução da camada de SAMI nos trechos T1 e T2

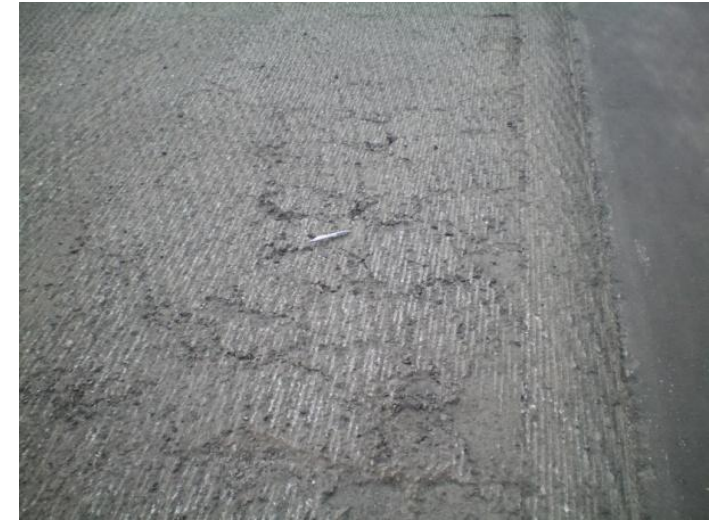

Figura 5. 13 - Fissuras na estrutura remanescente

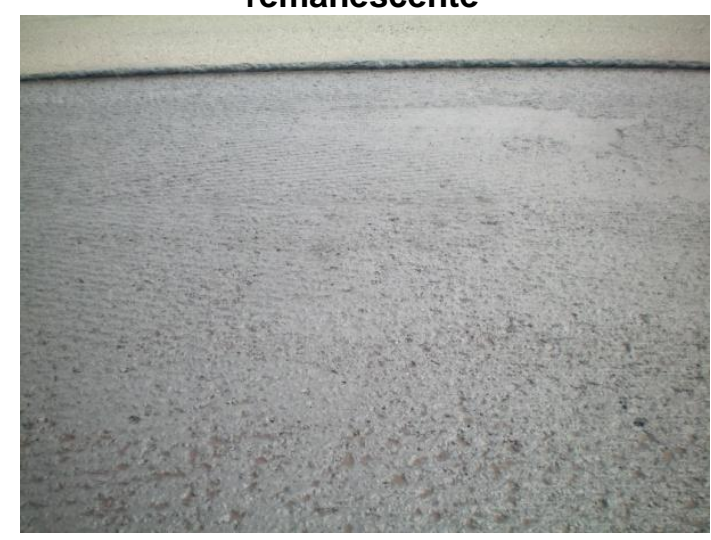

Figura 5. 15 - Pintura de ligação aplicada sobre a superfície fresada (2)

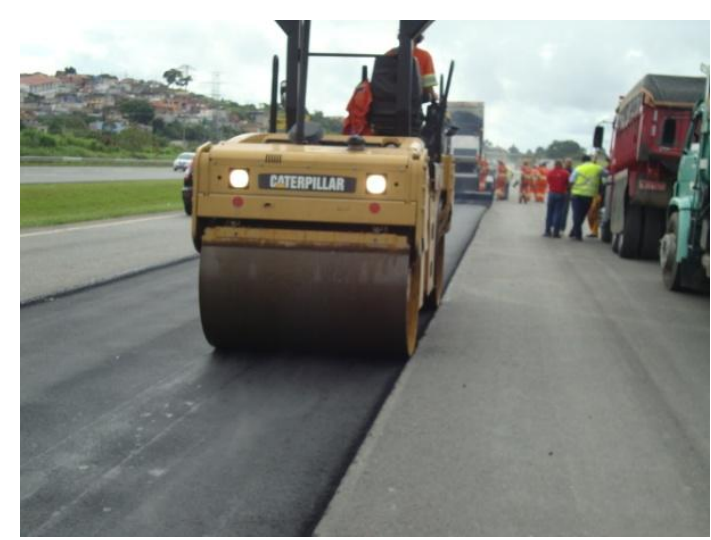

Figura 5. 17 - Compactação da camada de SAMI com rolo liso 


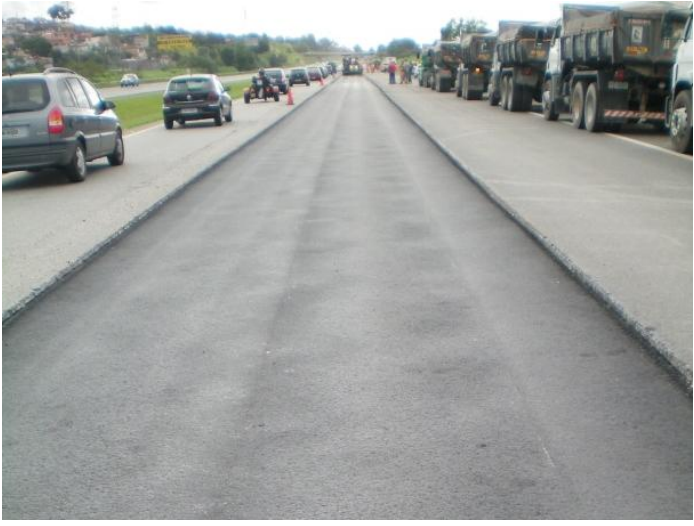

Figura 5. 18 - Camada de SAMI pronta

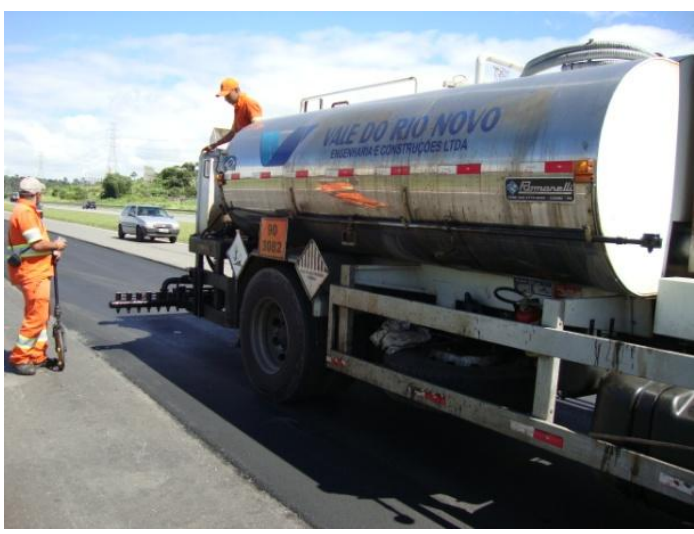

Figura 5. 20 - Aplicação da pintura de ligação sobre as camadas de SAMI, nos trechos T1 e T2, e sobre a camada asfáltica fresada no trecho $\mathrm{T} 3$

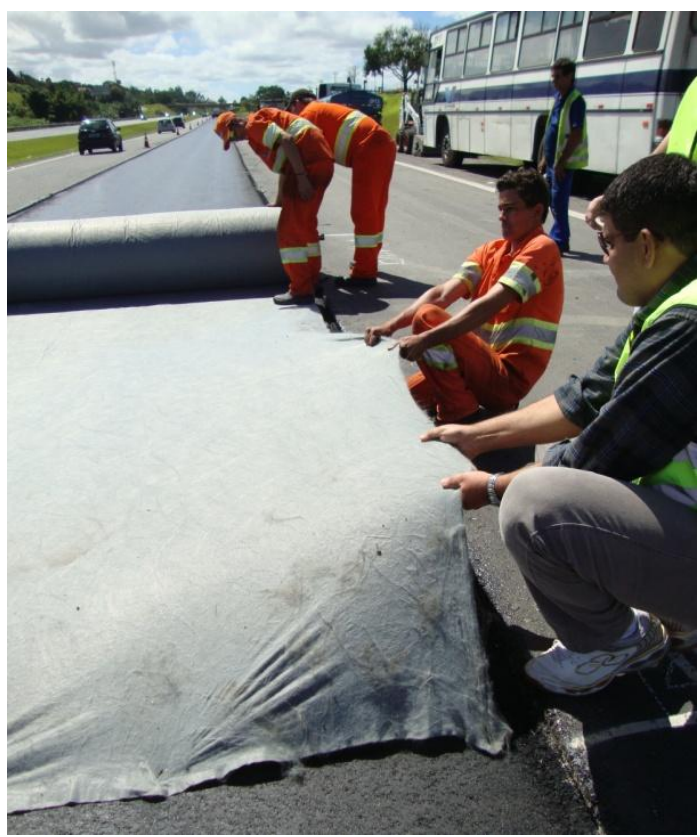

Figura 5. 22 - Aplicação do geotêxtil nos trechos T2 e T3

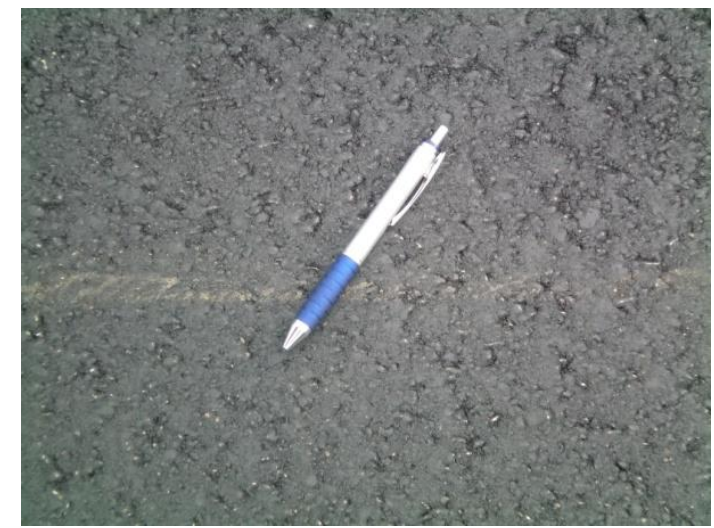

Figura 5. 19 - Textura final da superfície da camada de SAMI

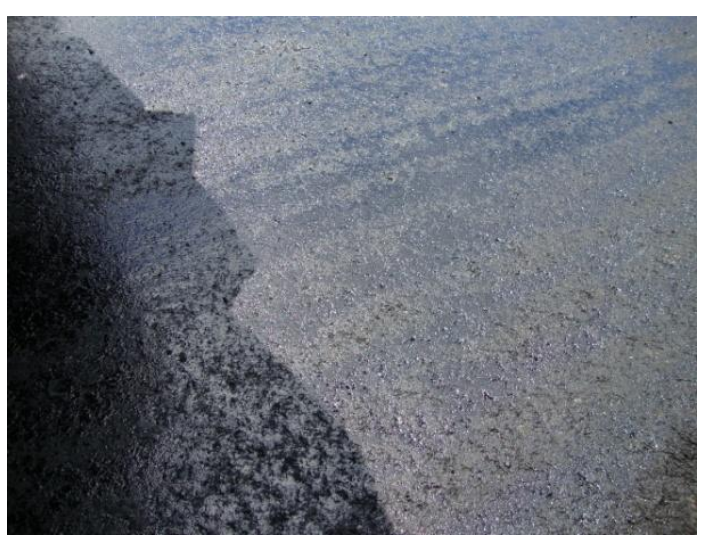

Figura 5. 21 - Pintura de ligação aplicada

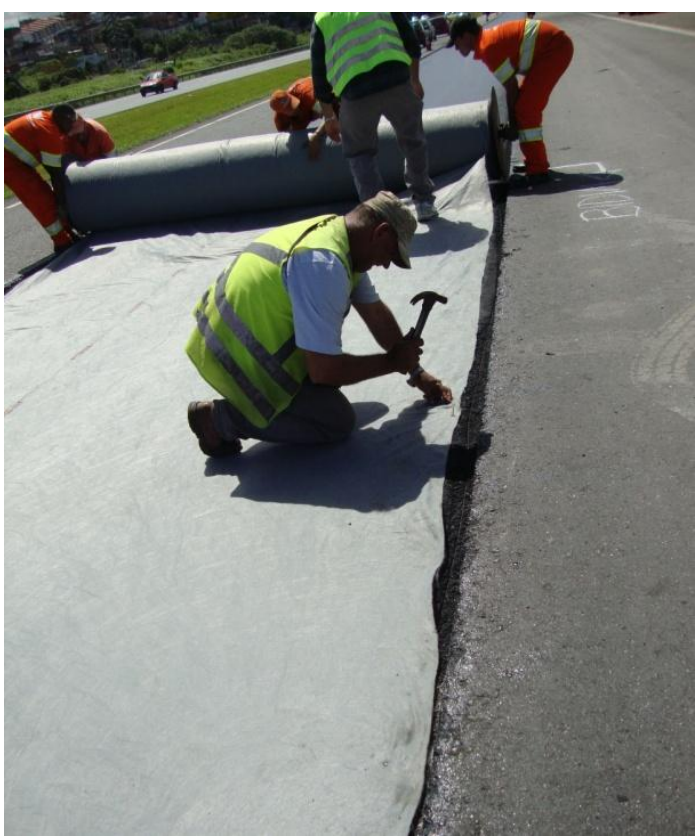

Figura 5. 23 - Fixação do geotêxtil com prego 


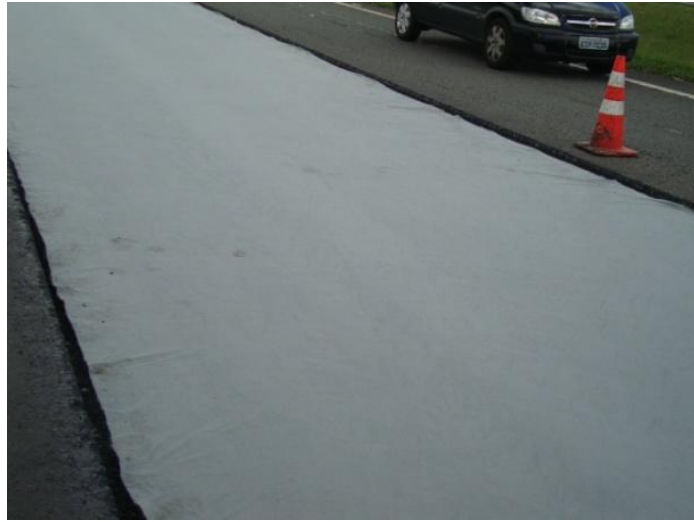

Figura 5. 24 - Geotêxtil aplicado nos trechos T2 e T3 (1)

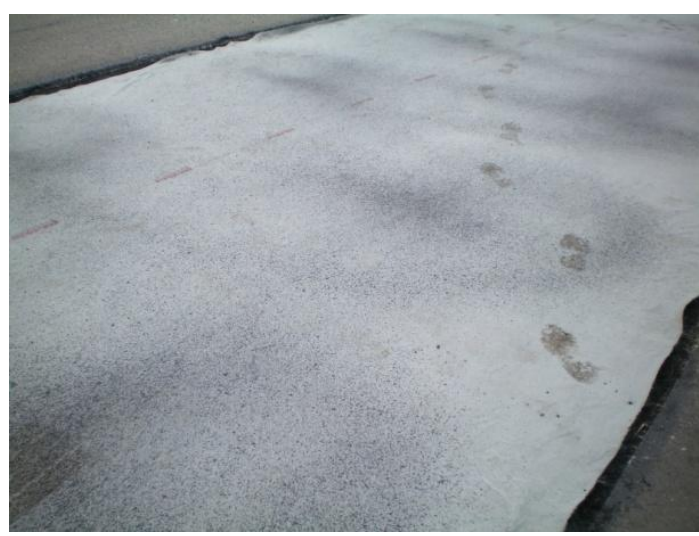

Figura 5. 26 - Pintura de ligação aplicada com caneta sobre o geotêxtil

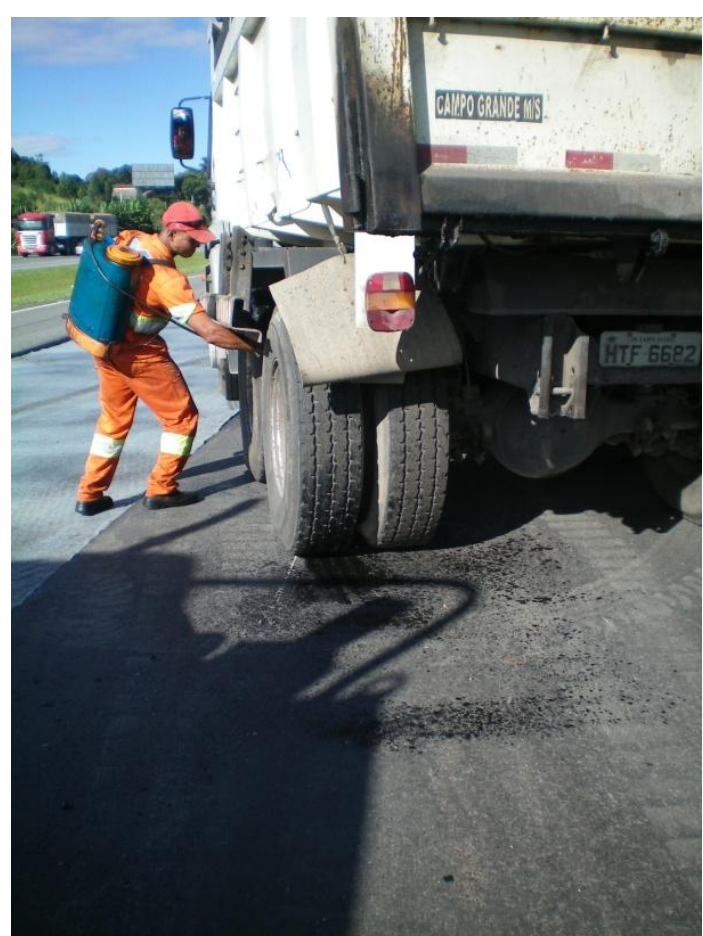

Figura 5. 28 - Aplicação de óleo mineral para evitar que o pneu do caminhão basculante arranque o geotêxtil

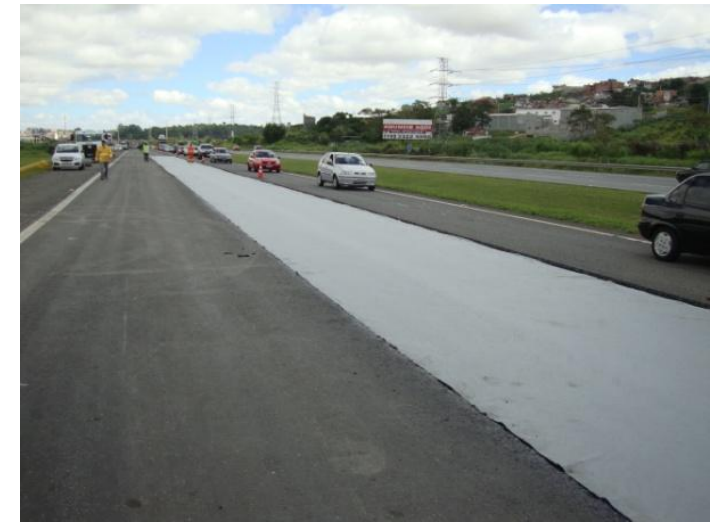

Figura 5. 25 - Geotêxtil aplicado nos trechos T2 e T3 (2)

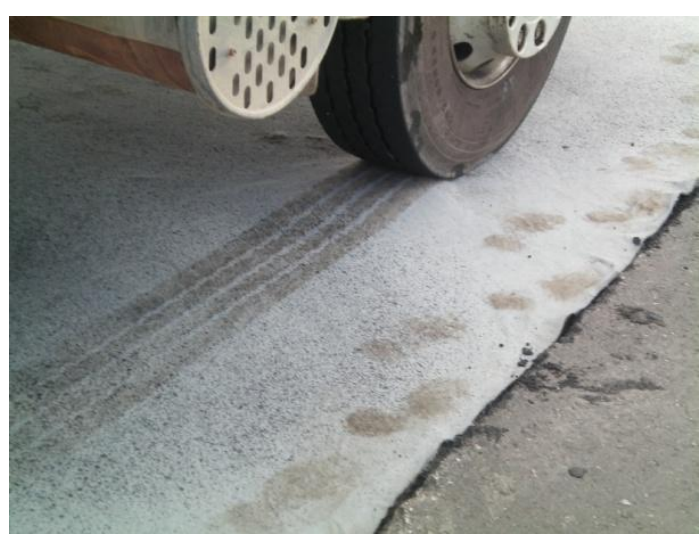

Figura 5. 27 - Manta geotêxtil grudando no pneu do caminhão

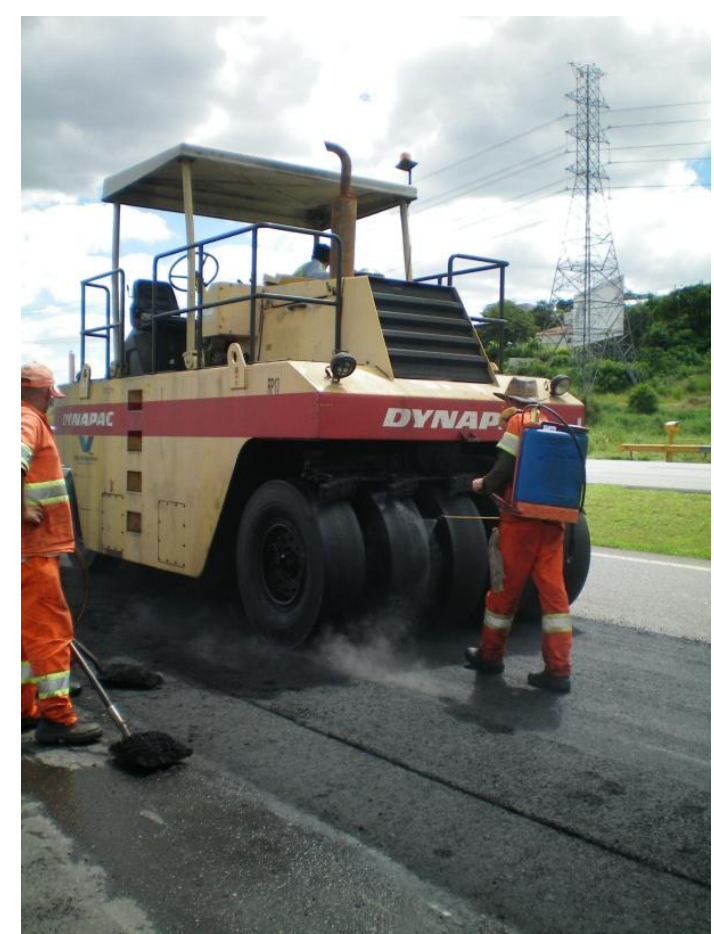

Figura 5. 29 - Aplicação de óleo mineral no rolo de pneu 


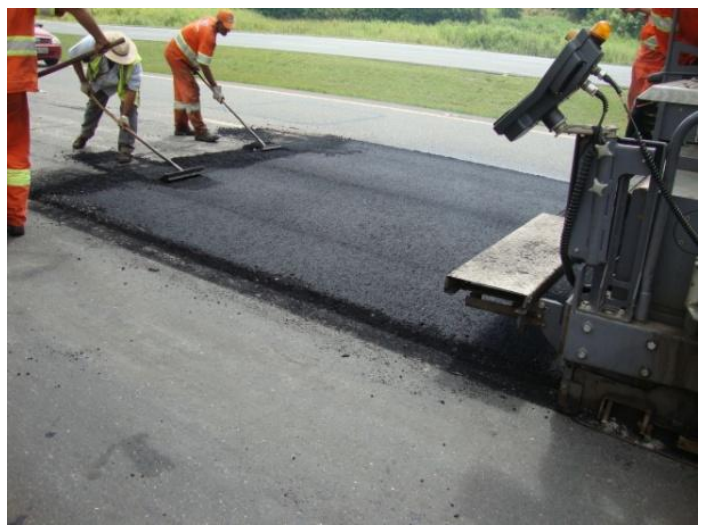

Figura 5. 30 - Execução da camada de CBUQ em todos os trechos

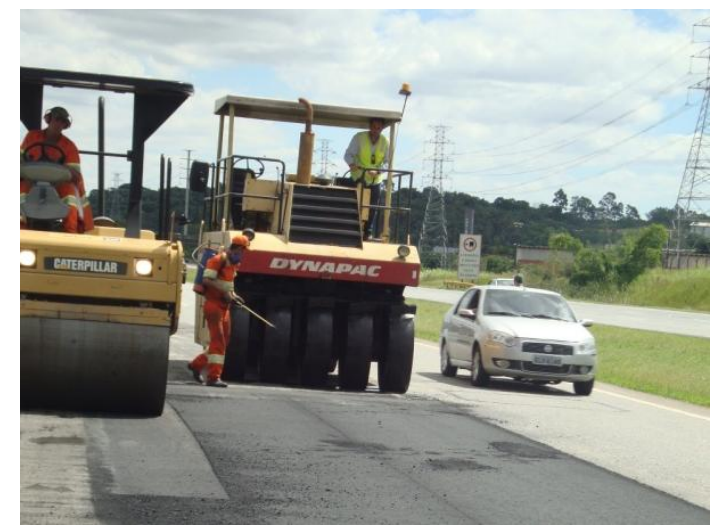

Figura 5. 31 - Compactação com rolos de pneu e liso

\subsubsection{Execução dos trechos T4, T5 e T6 (25/03/2012)}

No dia 25 de março de 2012, os outros três trechos restantes foram executados do $\mathrm{km} \mathrm{38,000}$ ao 38,750: T4 (SAMI+CBUQ com grelha na interface), T5 (CBUQ sobre camada fresada com grelha na interface) e T6 (CBUQ sobre camada fresada com pintura de ligação na interface). Utilizou-se para todos os trechos, a Emulsão 2 (RR-1C-E), a pedido do fabricante da grelha. A sequência de execução segue abaixo nas Figuras 5.32 a 5.51.

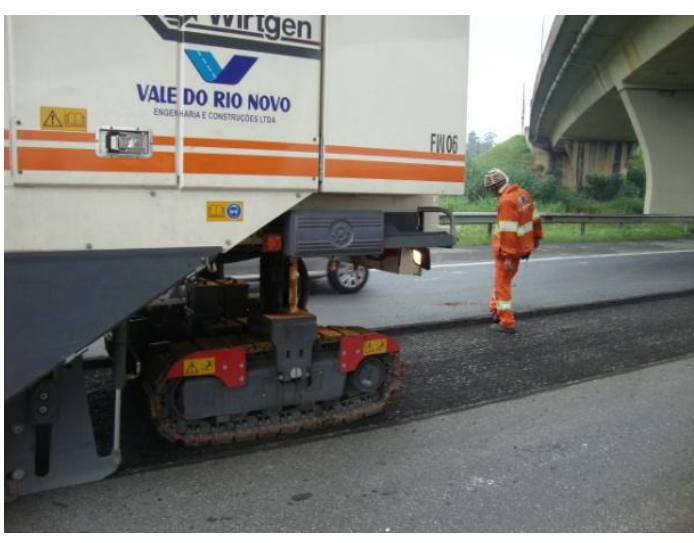

Figura 5. 32 - Fresagem de $6,0 \mathrm{~cm}$ da camada asfáltica antiga (1)

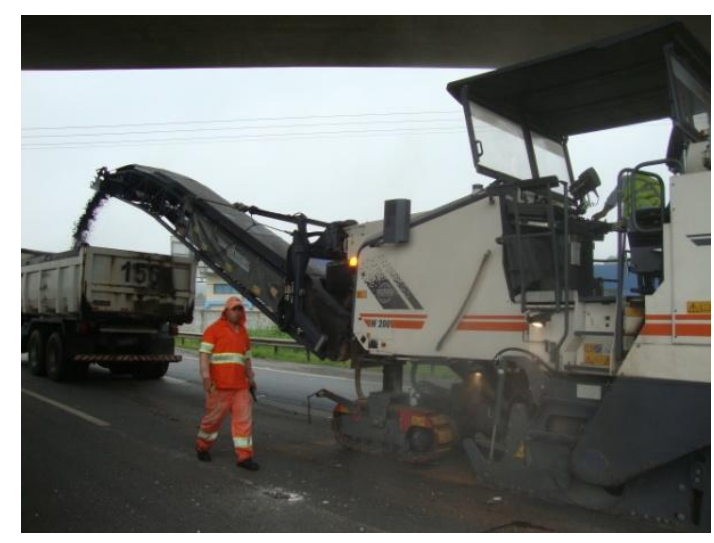

Figura 5. 33 - Fresagem da camada asfáltica antiga (2) 


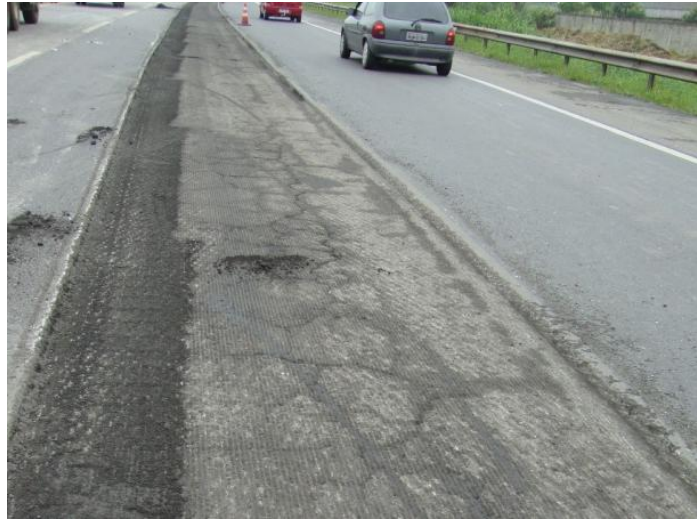

Figura 5. 34 - Caixa Fresada

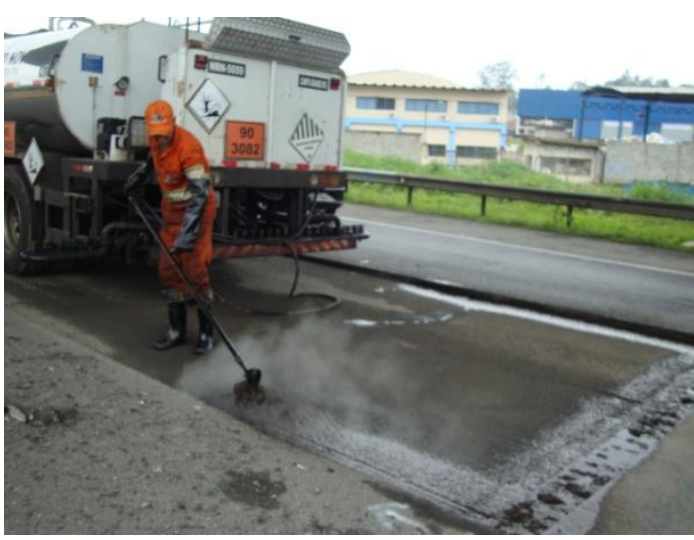

Figura 5. 36 - Aplicação de pintura de ligação nas bordas da caixa fresada com caneta

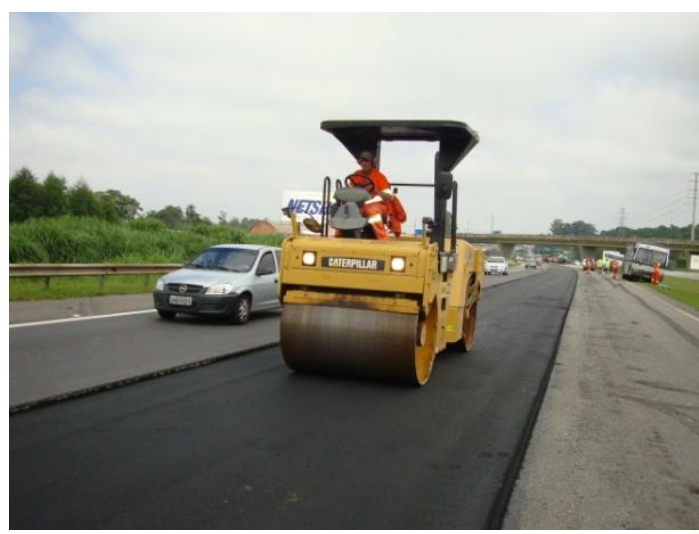

Figura 5.38 - Execução da camada de SAMI do trecho $\mathrm{T} 4$

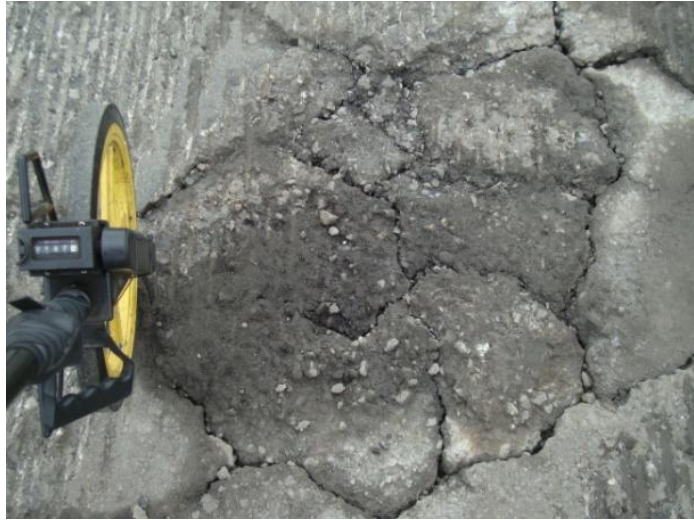

Figura 5. 35 - Trincamento acentuado na caixa remanescente $(\mathrm{km} 38,174)$

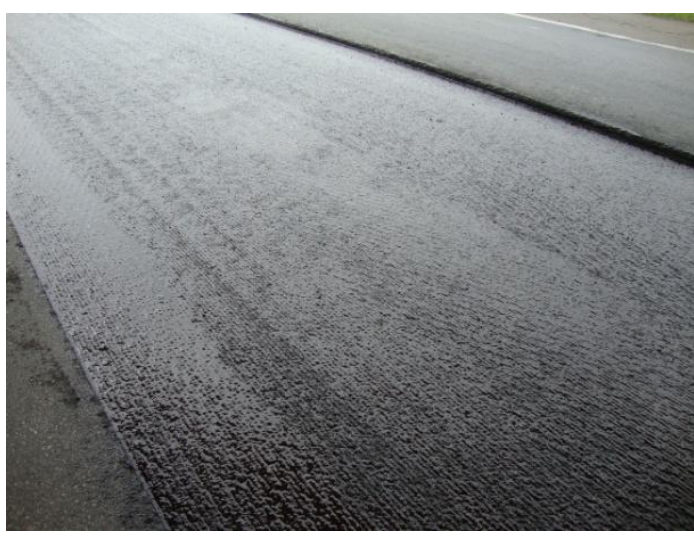

Figura 5. 37 - Superfície fresada com pintura de ligação aplicada por caminhão espargidor

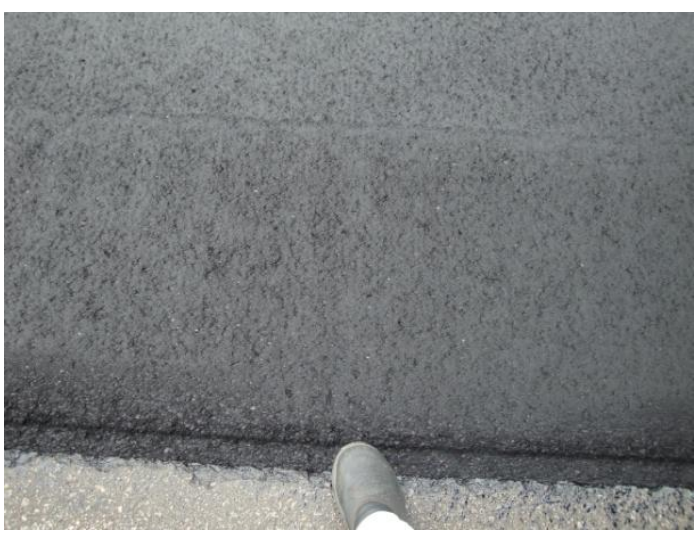

Figura 5.39 - Textura final da superfície da camada de SAMI no trecho T4 


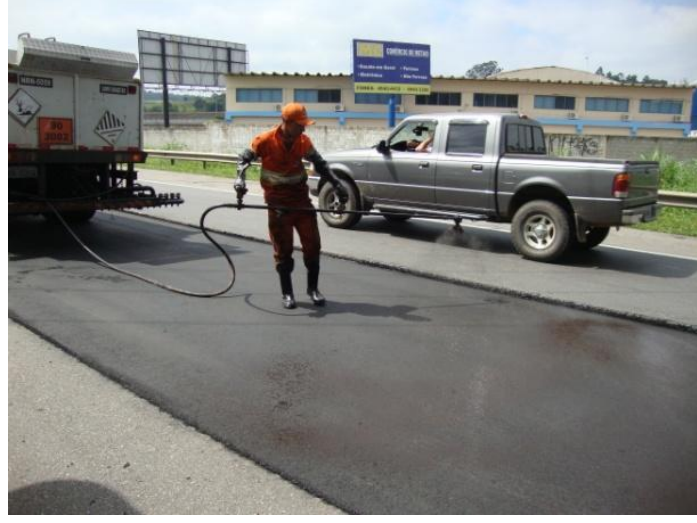

Figura 5.40 - Aplicação de pintura de ligação com caneta sobre a camada de SAMI no trecho T4

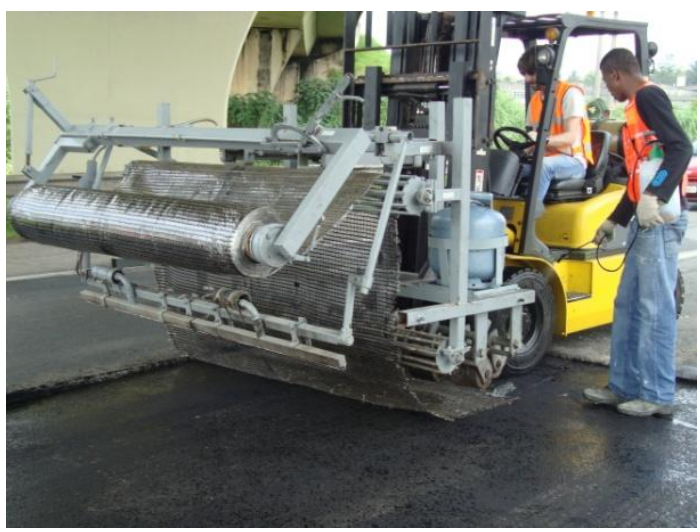

Figura 5.42 - Aplicação da grelha de fibra de vidro (2)

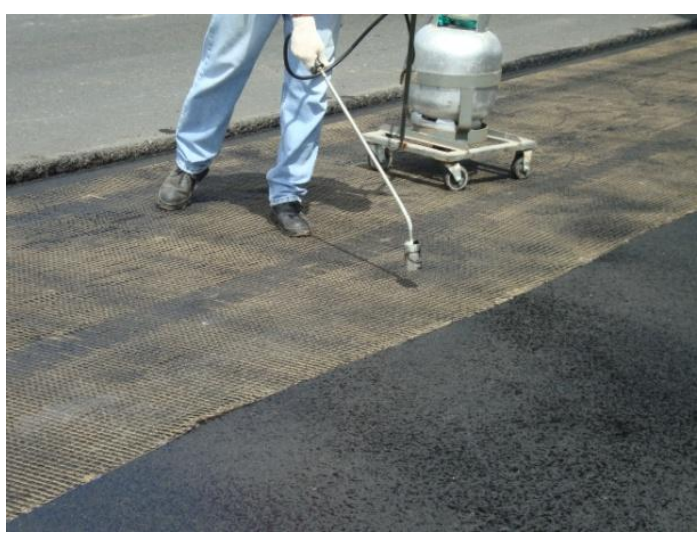

Figura 5.44 - Queima do filme plástico remanescente na grelha

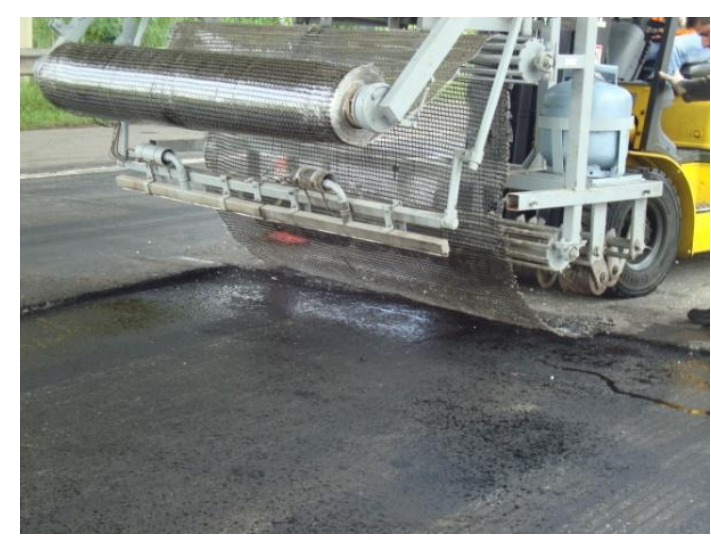

Figura 5.41 - Aplicação da grelha de fibra de vidro (1)

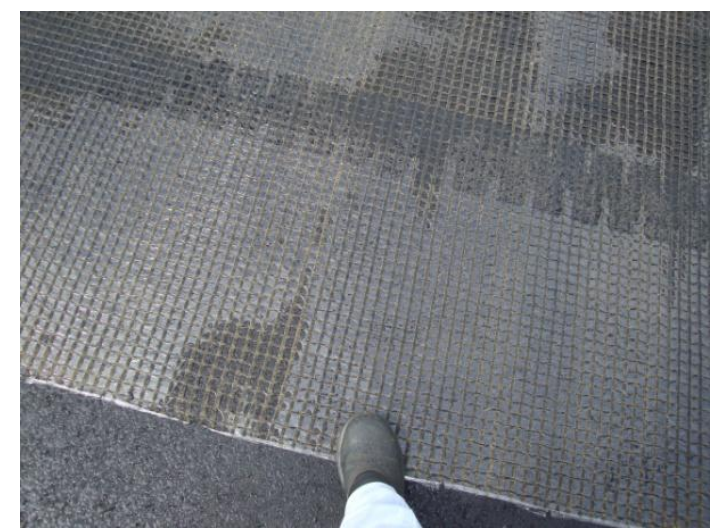

Figura 5.43 - Grelha aplicada

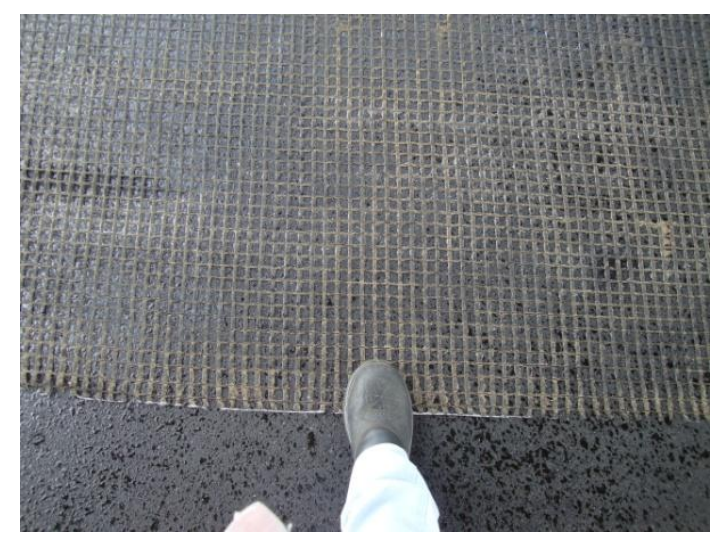

Figura 5.45 - Textura final da superfície com grelha 


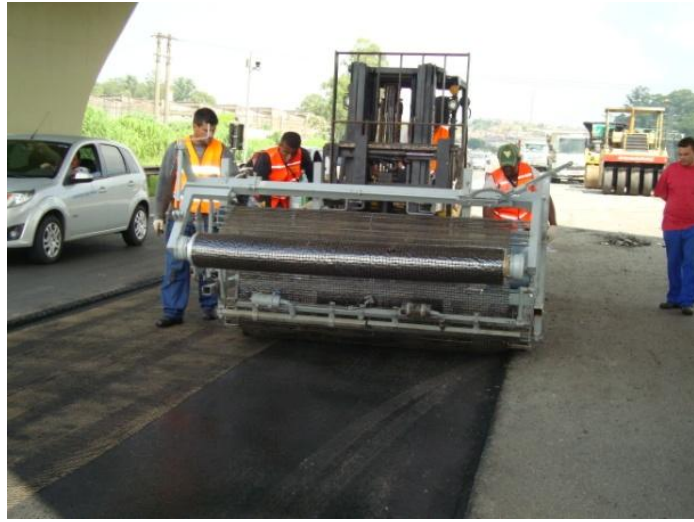

Figura 5.46 - Aplicação de segunda faixa de grelha

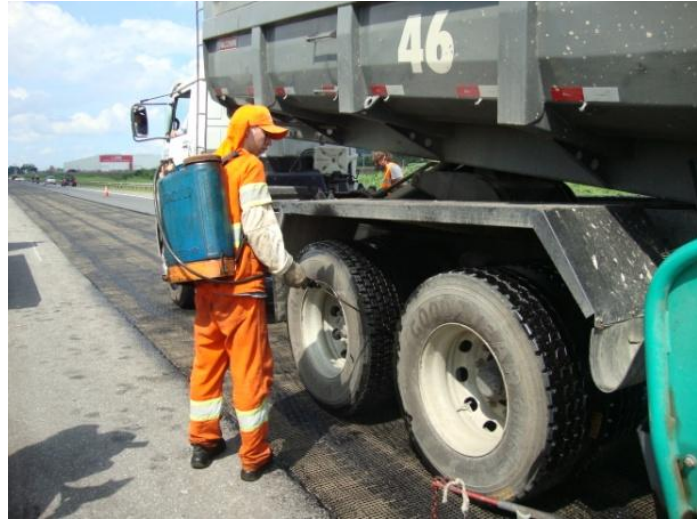

Figura 5.48 - Aplicação de óleo mineral para evitar que o pneu do caminhão basculante arranque a grelha

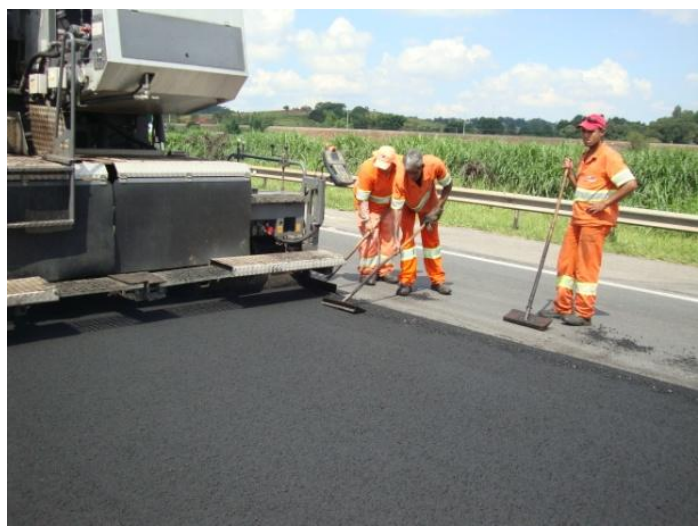

Figura 5.50 - Aplicação da camada de CBUQ

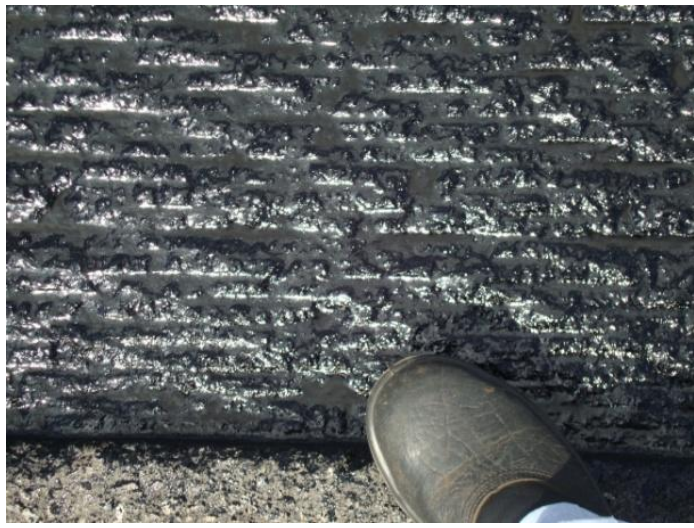

Figura 5.47 - Pintura de ligação na superfície fresada dos trechos T5 e T6

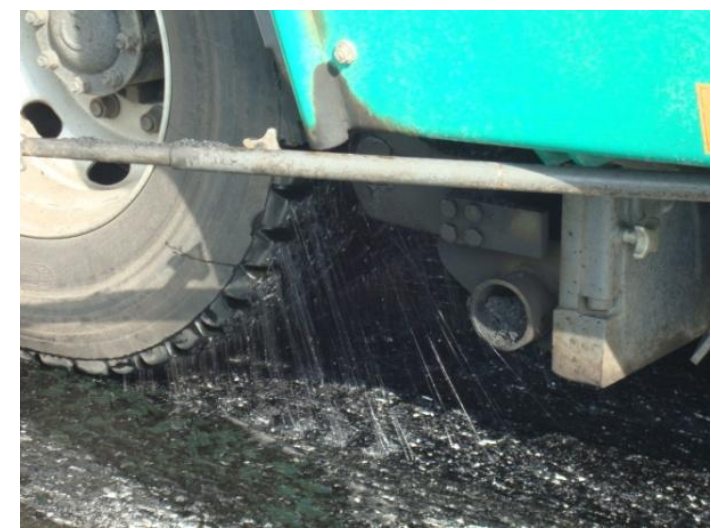

Figura 5.49 - Pintura de ligação com polímero aderindo ao pneu do caminhão

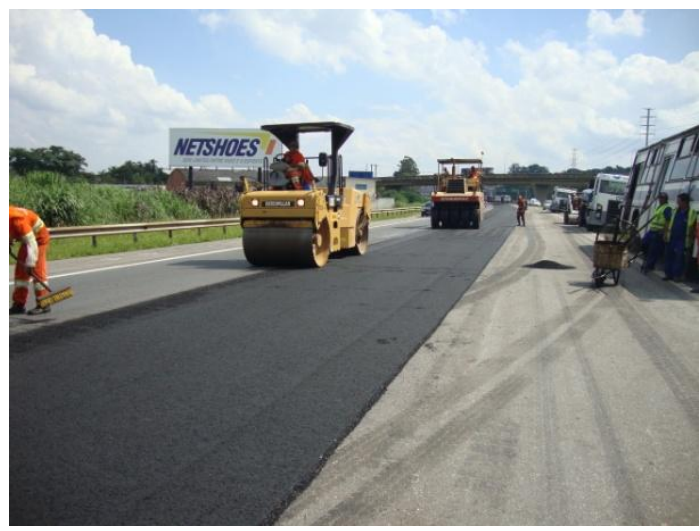

Figura 5.51 - Compactação da camada de CBUQ 
Nos dois dias de execução de obra, após execução das camadas de SAMI e antes da aplicação da pintura de ligação, esperou-se até que o pavimento atingisse temperaturas normais de serviço, em torno de $39^{\circ} \mathrm{C}$. A compactação da camada de SAMI foi feita apenas com rolo liso e na camada de CBUQ com rolo de pneu seguido por rolo liso.

Durante a execução dos trechos com geotêxtil (T2 e T3) percebeu-se grande dificuldade para manter o material esticado e fixado, tal qual é especificado para garantia de desempenho. Por esse motivo, a aplicação contou com a ajuda de pregos de fixação. Mesmo assim, em alguns lugares pontuais, o material apresentou bolhas de ar. Houve necessidade de refixação nesses locais. Ainda, durante a aplicação do CBUQ sobre esses mesmos trechos, o geotêxtil grudou, em alguns pontos, na roda do caminhão basculante e na esteira da vibroacabadora, mesmo com aplicação de óleo mineral nos pneus.

Em cada caminhão, foram tomadas as medidas de temperatura da mistura na vibroacabadora e na pista (Figuras 5.52 e 5.53), com valores variando de 140 a $150^{\circ} \mathrm{C}$.

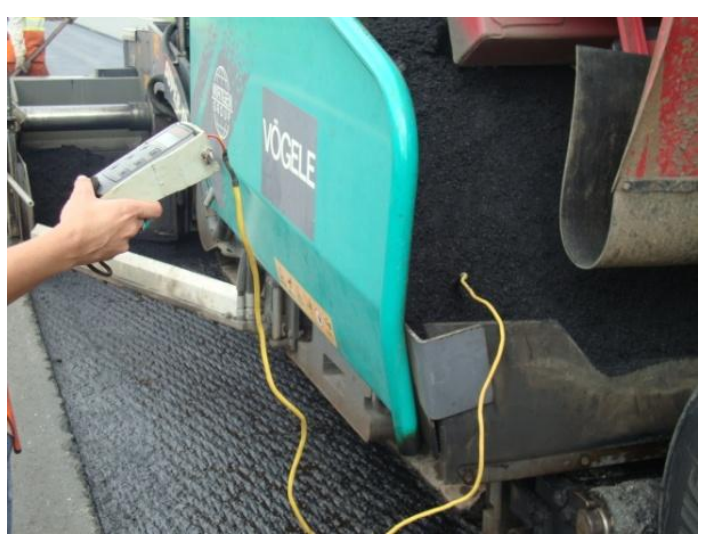

Figura 5.52 - Controle de temperatura na vibroacabadora

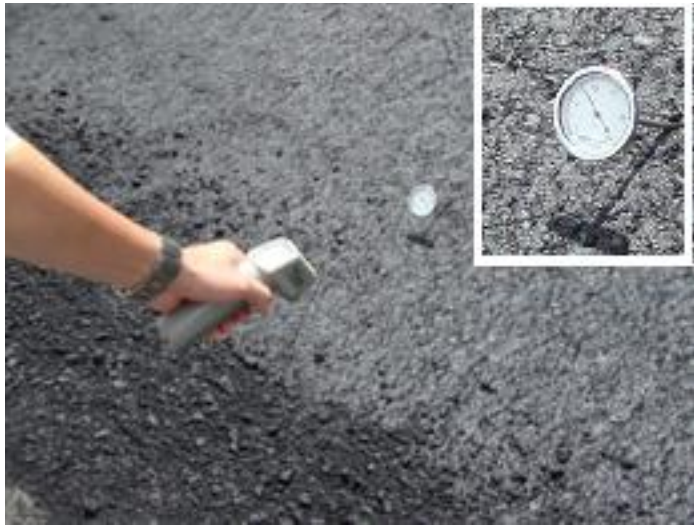

Figura 5.53 - Controle de temperatura em pista após lançamento da mistura

As taxas de aplicação da pintura de ligação foram medidas entre a camada asfáltica remanescente (CAR) e a camada sobreposta, ora de SAMI (T1, T2 e T4) ora de CBUQ (T3, T5 e T6) e entre SAMI e CBUQ para o trecho T2. No trecho T1, na interface entre SAMI e CBUQ, não foi medida a taxa aplicada. A aplicação nos casos acima mencionados foi feita com caminhão espargidor. 
A pintura de ligação entre a camada de SAMI e de CBUQ no trecho T4 foi aplicada com caneta e a taxa (muito baixa) não foi medida nesse caso. O mesmo ocorreu para aplicação da pintura de ligação sobre o geotêxtil (trechos T2 e T3), conforme mostra a Figura 5.26, por receio de o excesso de pintura inviabilizar o tráfego dos caminhões basculantes sobre o geotêxtil. Não houve aplicação de pintura de ligação sobre a grelha nos trechos T4 e T5, sendo a pintura aplicada apenas abaixo dela.

Em todos os casos, antes da execução da camada seguinte esperou-se a ruptura completa da emulsão asfáltica utilizada como pintura de ligação. A Tabela 5.1 abaixo traz os valores encontrados para taxa de aplicação utilizada em cada um dos casos. Cabe lembrar que os valores levantados em campo e apresentados na Tabela 5.1 são de taxa de emulsão conforme aplicada e não do resíduo de ligante (Emulsão 1 com recorte de 30\% e Emulsão 2 sem recorte). As Figuras 5.54 e 5.55 mostram a medição dessas taxas em campo e a emulsão após aplicação, respectivamente.

Tabela 5.1 - Taxas de aplicação da pintura de ligação em campo

\begin{tabular}{|c|c|c|c|c|}
\hline & Trecho & Local & \multicolumn{2}{|c|}{$\begin{array}{c}\text { Taxa de aplicação da } \\
\text { pintura de ligação }\left(\mathrm{L} / \mathrm{m}^{2}\right)\end{array}$} \\
\hline \multicolumn{5}{|c|}{ Emulsão 2 (25/03/2012) - Taxa da aplicação de emulsão sem recorte: T4, T5, T6 } \\
\hline \multirow{5}{*}{ T4 } & & GRELHA - CBUQ & \multicolumn{2}{|c|}{ Não houve aplicação } \\
\hline & CBUQ & SAMI - GRELHA & \multicolumn{2}{|c|}{ Aplicação com caneta } \\
\hline & SAMI PINTURA LIG. & & \multicolumn{2}{|l|}{0,758} \\
\hline & \multirow[t]{2}{*}{\begin{tabular}{|l}
\multicolumn{1}{c}{ PINTURA LIG. } \\
CAMADA ASFÁLTICA \\
REMANESCENTE (CAR)
\end{tabular}} & CAR - SAMI & 1,000 & 0,928 \\
\hline & & & \multicolumn{2}{|l|}{1,025} \\
\hline \multirow{4}{*}{ T5 } & \multirow[t]{2}{*}{ CBUQ } & GRELHA - CBUQ & \multicolumn{2}{|c|}{ Não houve aplicação } \\
\hline & & \multirow{3}{*}{ CAR-GRELHA } & 0,966 & \multirow{3}{*}{0,933} \\
\hline & \multirow{2}{*}{$\begin{array}{l}\text { PINTURA LIG. } \\
\text { CAMADA ASFÁLTICA } \\
\text { REMANESCENTE (CAR) }\end{array}$} & & 0,883 & \\
\hline & & & 0,950 & \\
\hline
\end{tabular}


Trecho

Local

Taxa de aplicação da pintura de ligação $\left(\mathrm{L} / \mathrm{m}^{2}\right)$

Emulsão 2 (25/03/2012) - Taxa da aplicação de emulsão sem recorte: T4, T5, T6

\begin{tabular}{|c|c|c|c|c|}
\hline \multirow{4}{*}{ T6 } & \multirow[t]{2}{*}{$\overline{\text { CBUQ }}$} & \multirow{4}{*}{ CAR - CBUQ } & 0,333 & \multirow{4}{*}{0,358} \\
\hline & & & 0,383 & \\
\hline & PINTURA LIG. & & & \\
\hline & $\begin{array}{l}\text { CAMADADASFÁALIICA } \\
\text { REMANESCENTE (CAR) }\end{array}$ & & 0,358 & \\
\hline
\end{tabular}

Emulsão 1 (18/03/2012) - Taxa de aplicação da emulsão com recorte de 30\%: T1, T2, T3

\begin{tabular}{|c|c|c|c|c|}
\hline \multirow{4}{*}{ T1 } & CBUQ & SAMI-CBUQ & \multicolumn{2}{|c|}{ Não houve medição } \\
\hline & & \multirow{3}{*}{ CAR-SAMI } & 0,875 & \multirow{3}{*}{0,875} \\
\hline & \multirow{2}{*}{$\begin{array}{c}\text { PINTURA LIG. } \\
\text { CAMADA ASFALTICA } \\
\text { REMANESCENTE (CAR) }\end{array}$} & & 0,891 & \\
\hline & & & 0,858 & \\
\hline \multirow{5}{*}{ T2 } & CBUQ & GEOTÊXTIL - CBUQ & \multicolumn{2}{|c|}{ Aplicação com caneta } \\
\hline & SAMI PINTURA LIG. & SAMI-GEOTÊXTIL & \multicolumn{2}{|c|}{0,158} \\
\hline & \multirow{3}{*}{$\begin{array}{l}\text { PINTURA LIG. } \\
\text { CAMADA ASFÁLTICA } \\
\text { REMANESCENTE (CAR) }\end{array}$} & \multirow{3}{*}{ CAR-SAMI } & 0,983 & \multirow{3}{*}{0,980} \\
\hline & & & 0,958 & \\
\hline & & & 1,000 & \\
\hline \multirow{4}{*}{ T3 } & \multirow[t]{2}{*}{ CBUQ } & & \multirow{2}{*}{\multicolumn{2}{|c|}{ Aplicação com caneta }} \\
\hline & & GEOTÊXTIL - CBUQ & & \\
\hline & PINTURA LIG. & \multirow{2}{*}{ CAR-GEOTÊXTIL } & 0,816 & \multirow{2}{*}{0,808} \\
\hline & $\begin{array}{l}\text { CAMADA ASFÁLTICA } \\
\text { REMANESCENTE (CAR) }\end{array}$ & & 0,8 & \\
\hline
\end{tabular}
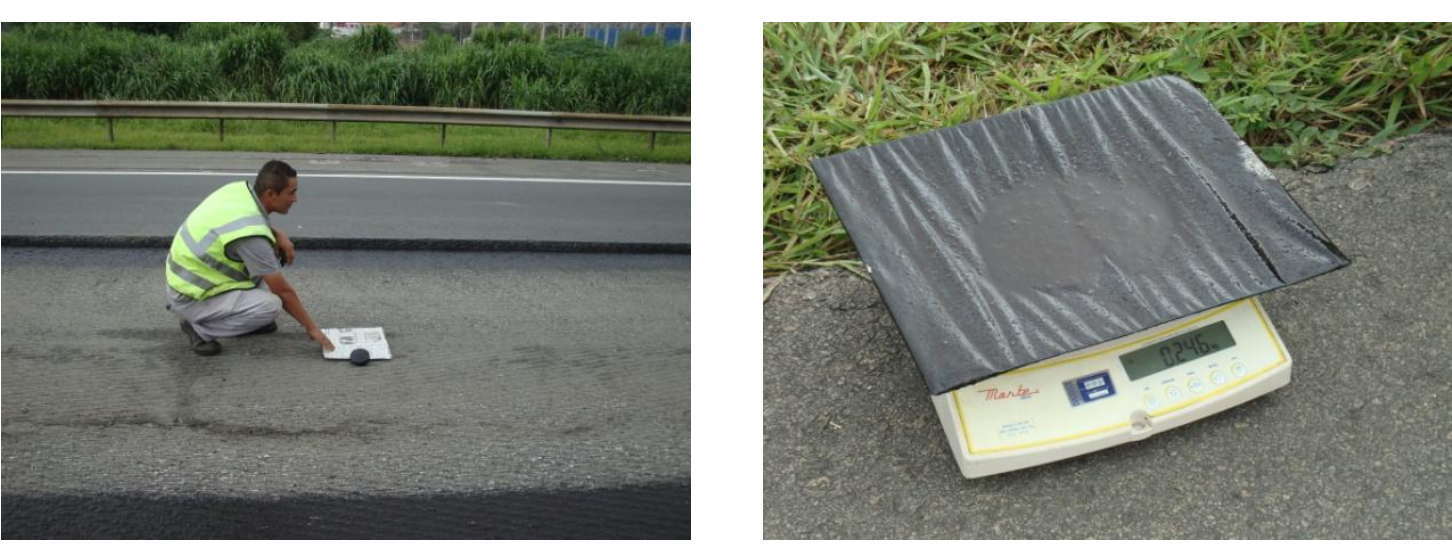

Figura 5.54 - Medidas da taxa de aplicação da pintura de ligação em campo 


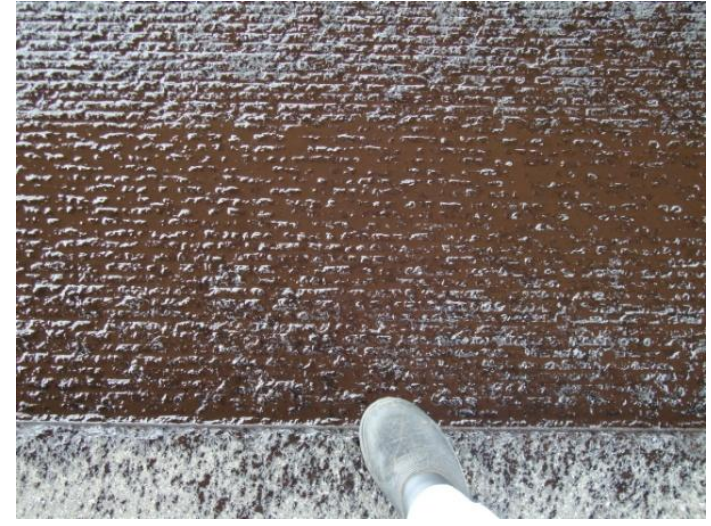

(a)

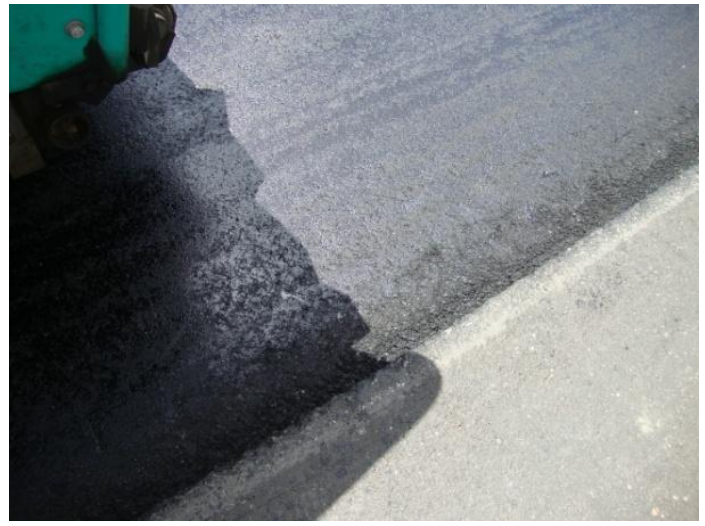

(b)

Figura 5.55 - Pintura de ligação aplicada, (a) antes e (b) depois da ruptura

Após conclusão dos serviços de pavimentação e durante a execução da pintura de sinalização, fez-se, ainda, levantamento da irregularidade longitudinal da pista com equipamento Merlin, conforme Figura 5.56. Durante a execução da obra, nos dois dias, não houve ocorrência de chuva. A temperatura ambiente variou de 21 a $36^{\circ} \mathrm{C}$ no dia $18 / 03$ e de 27 a $37^{\circ} \mathrm{C}$ no dia $25 / 03$.

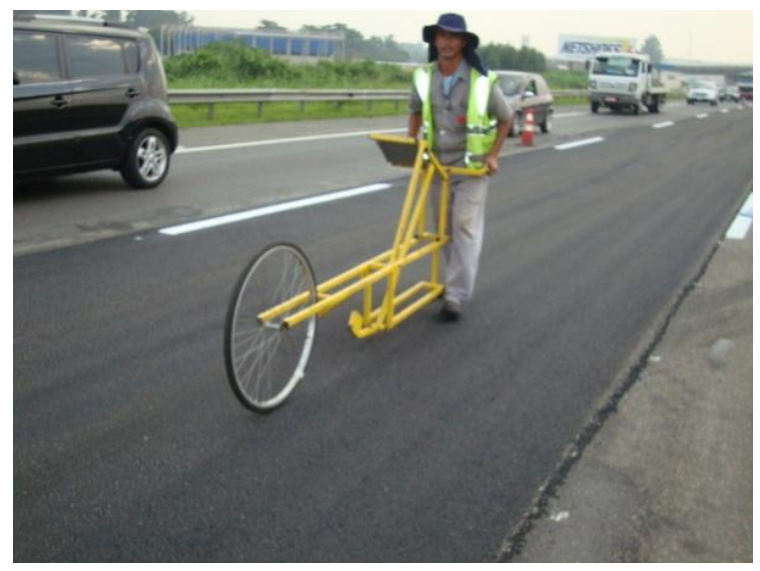

Figura 5. 56 - Levantamento Merlin após a obra

\subsection{MONITORAMENTO DO TRECHO EXPERIMENTAL}

Para o acompanhamento do desempenho do trecho experimental ao longo do tempo, estão previstos levantamentos deflectométricos a cada 3 meses durante 0 primeiro ano, levantamentos por vídeo filmagem das condições superficiais de pista quando o surgimento de trincas e irregularidades forem visualmente pronunciados, e extração de corpos de prova cilíndricos para ensaio de cisalhamento Leutner, também a cada 3 meses. 
Como referência, foram levantadas as deflexões de campo nas datas da obra (18/03 e 25/03), na estrutura existente e na estrutura remanescente, já com a caixa fresada. Na caixa fresada, foi ainda executado levantamento deflectométrico com equipamento LWD para comparação das medidas encontradas com o equipamento FWD. A retirada dos corpos de prova para ensaio de cisalhamento Leutner também se deu em data inicial, abril de 2012, em todo o trecho experimental. A filmagem utilizada como referência será a já citada no item 5.1.1 deste documento, executada em fevereiro de 2012.

Até a presente data, foram feitos mais dois levantamentos FWD e duas campanhas de extrações de corpos de prova cilíndricos, ambos executados em julho e setembro de 2012, três e seis meses após a execução da obra, respectivamente. A vídeo filmagem ainda não foi programada porque visualmente não houve surgimento de trincas em nenhum dos trechos.

\subsubsection{Levantamento deflectométrico}

O levantamento com equipamento FWD foi realizado pela Dynatest, com carga média de 4,1 t. O monitoramento estrutural do trecho foi feito em 3 etapas:

- Data OA (18/03/12 nos trechos T1, T2 e T3 e 25/03/12 nos trechos T4, T5 e T6): FWD na superfície do pavimento existente antes da intervenção; - Data OB (18/03/12 nos trechos T1, T2 e T3 e 25/03/2012 nos trechos T4, T5 e T6): FWD na superfície da caixa fresada (infraestrutura remanescente);

- Data 1 (01/07/12 em todo o trecho experimental): FWD após 3 meses da execução da obra;

- Data 2 (09/09/12 em todo o trecho experimental): FWD após 6 meses da execução da obra.

A Figura 5.57 traz os resultados de FWD encontrados, em cada caso. 


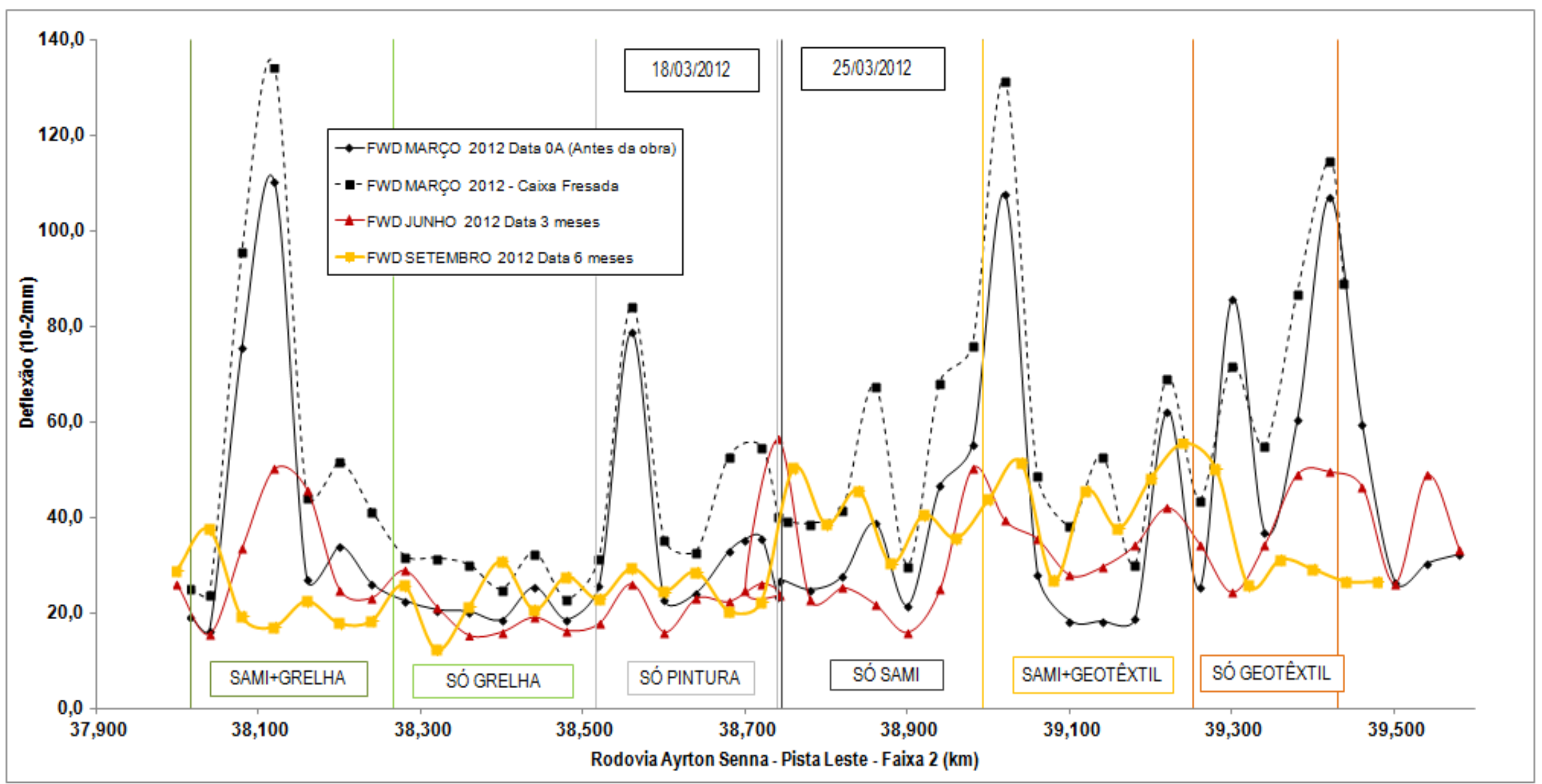

Figura 5.57 - Resultados do monitoramento com FWD 
A fim de melhor interpretar os dados vindos de campo analisaram-se as bacias de deflexão obtidas pelo levantamento com o FWD. Os gráficos resultantes estão apresentados, para cada trecho, com os quatro levantamentos executados (antes da obra, na caixa fresada, após 3 meses e após 6 meses) nas Figuras 5.58 a 5.63. Os dados apresentados correspondem aos valores da bacia média, após eliminação de pontos fora do intervalo, utilizando a equação 4.1 citada anteriormente.

Também foram eliminados os pontos próximos às junções entre segmentos diferentes para não afetar a análise das soluções individualmente propostas.

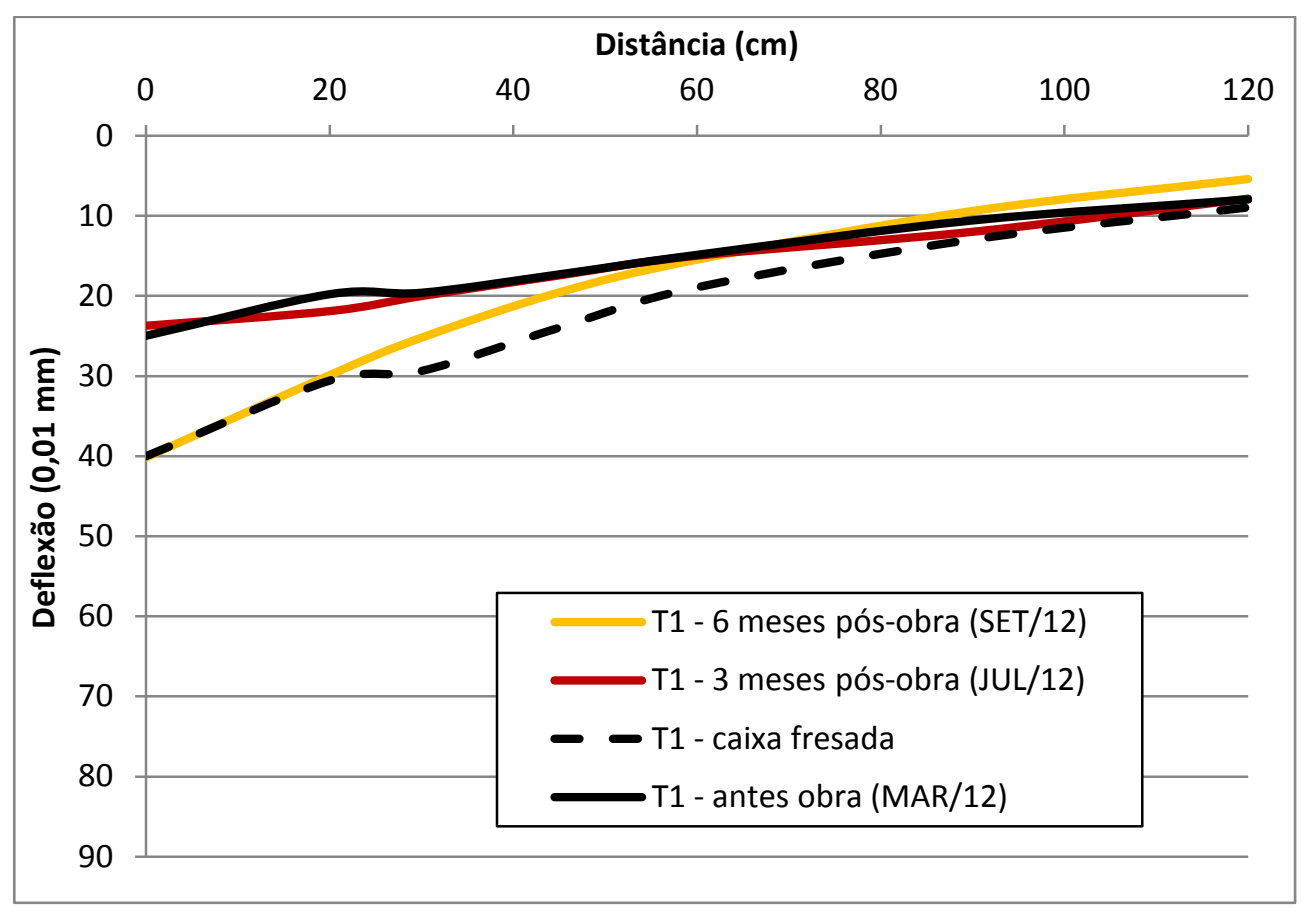

Figura 5.58 - Bacia de deflexão média do levantamento FWD para o trecho T1 (CBUQ+SAMI com pintura de ligação na interface) 


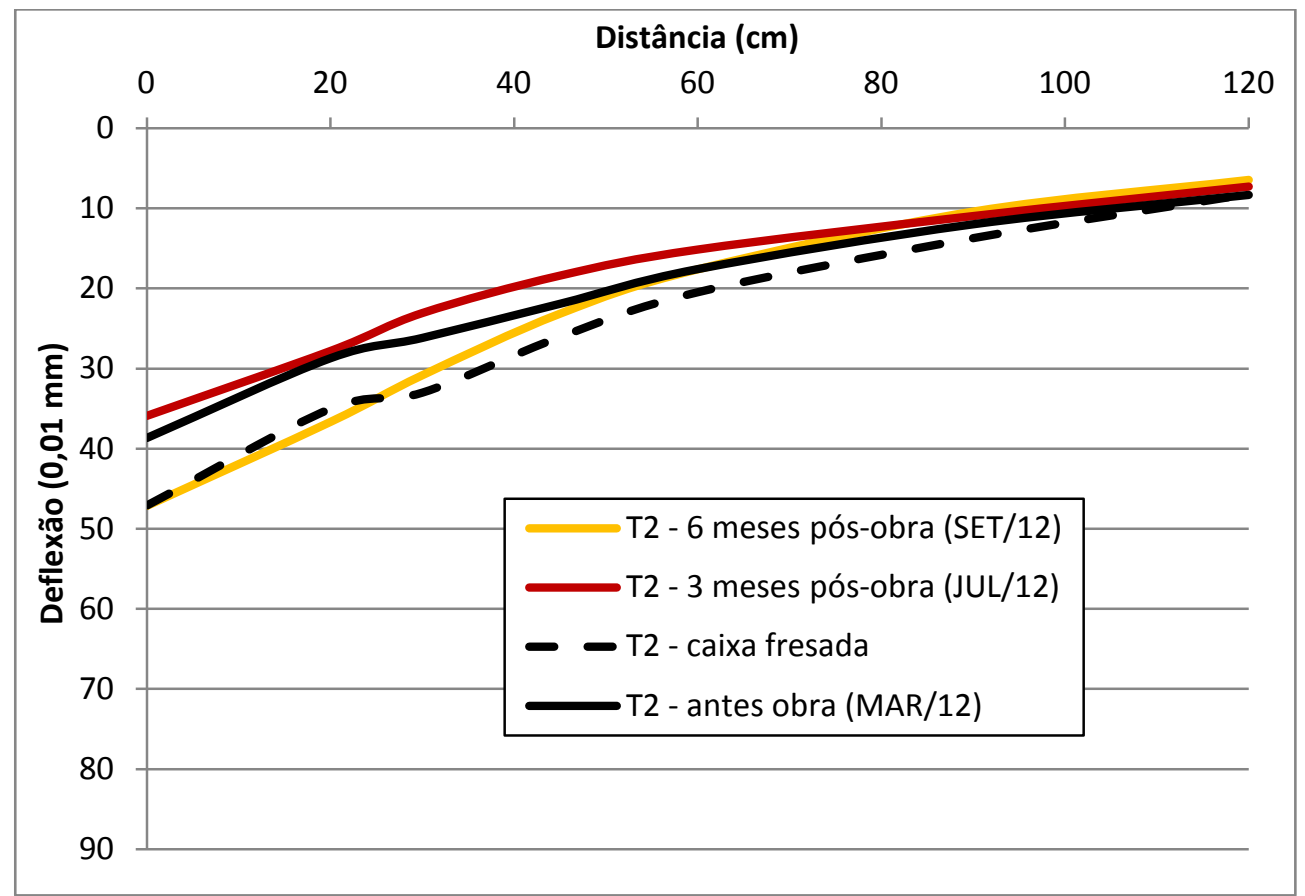

Figura 5.59 - Bacia de deflexão média do levantamento FWD para o trecho T2 (CBUQ+SAMI com geotêxtil na interface)

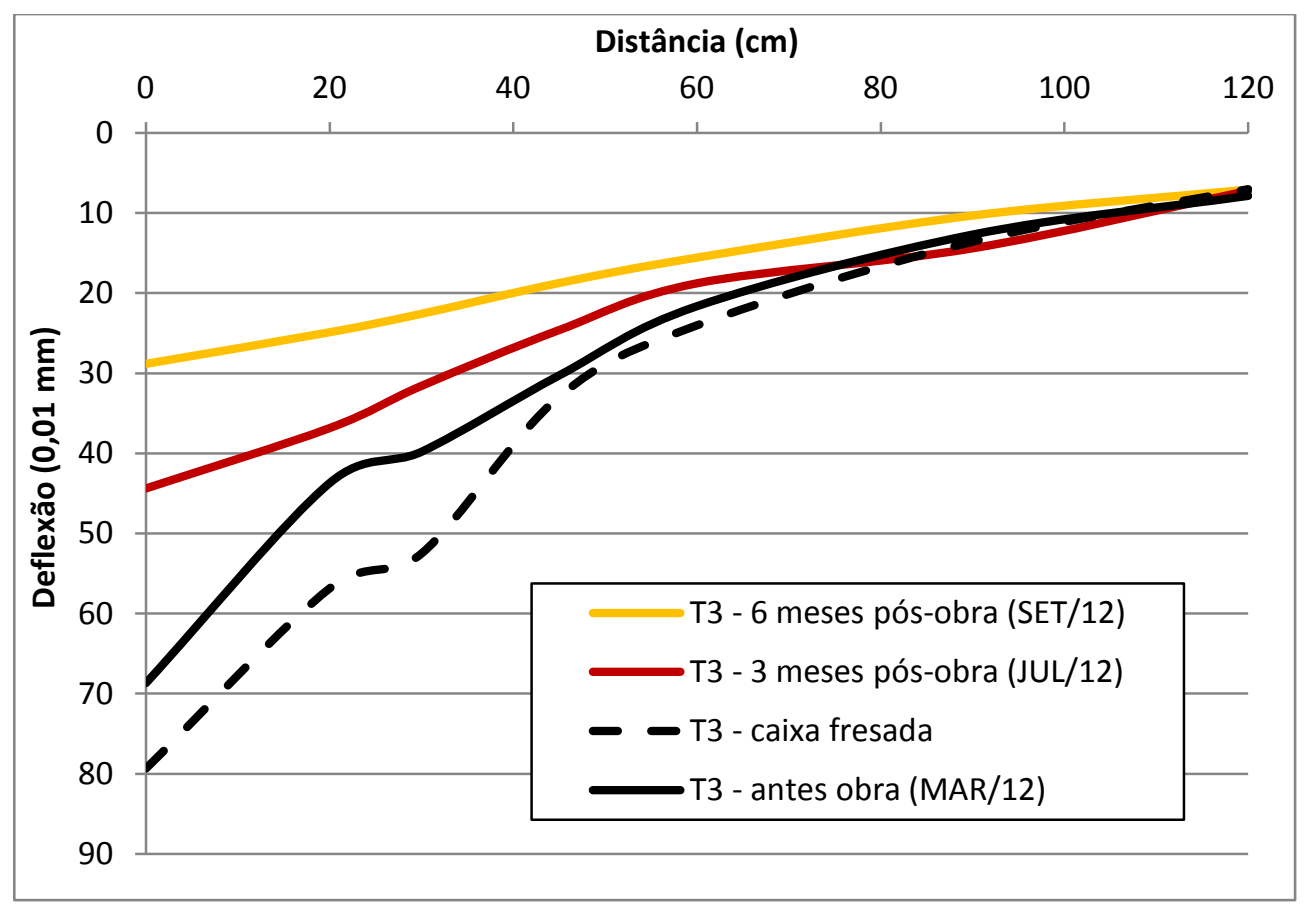

Figura 5.60 - Bacia de deflexão média do levantamento FWD para o trecho T3 (CBUQ sobre superfície fresada com geotêxtil na interface) 


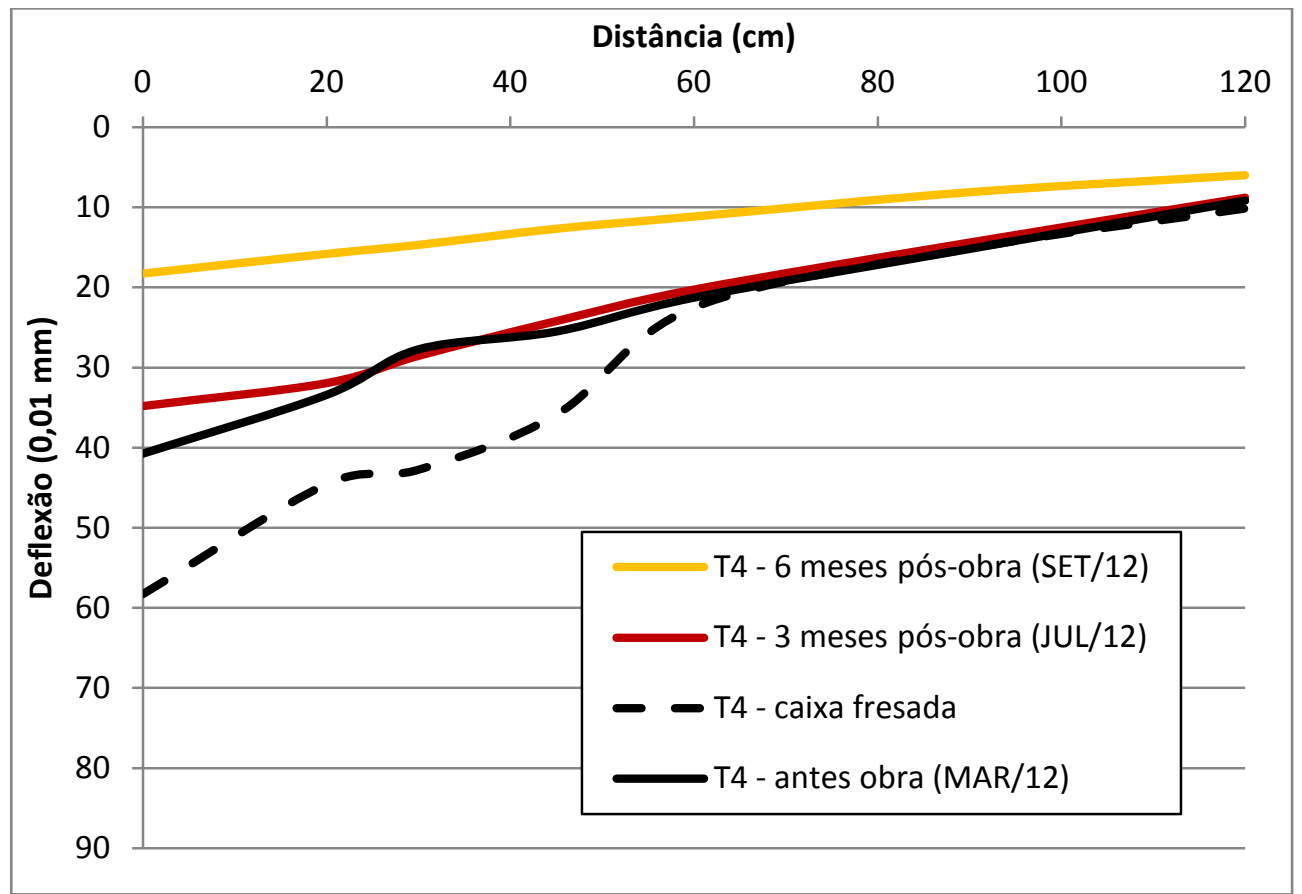

Figura 5.61 - Bacia de deflexão média do levantamento FWD para o trecho T4 (CBUQ+SAMI com grelha na interface)

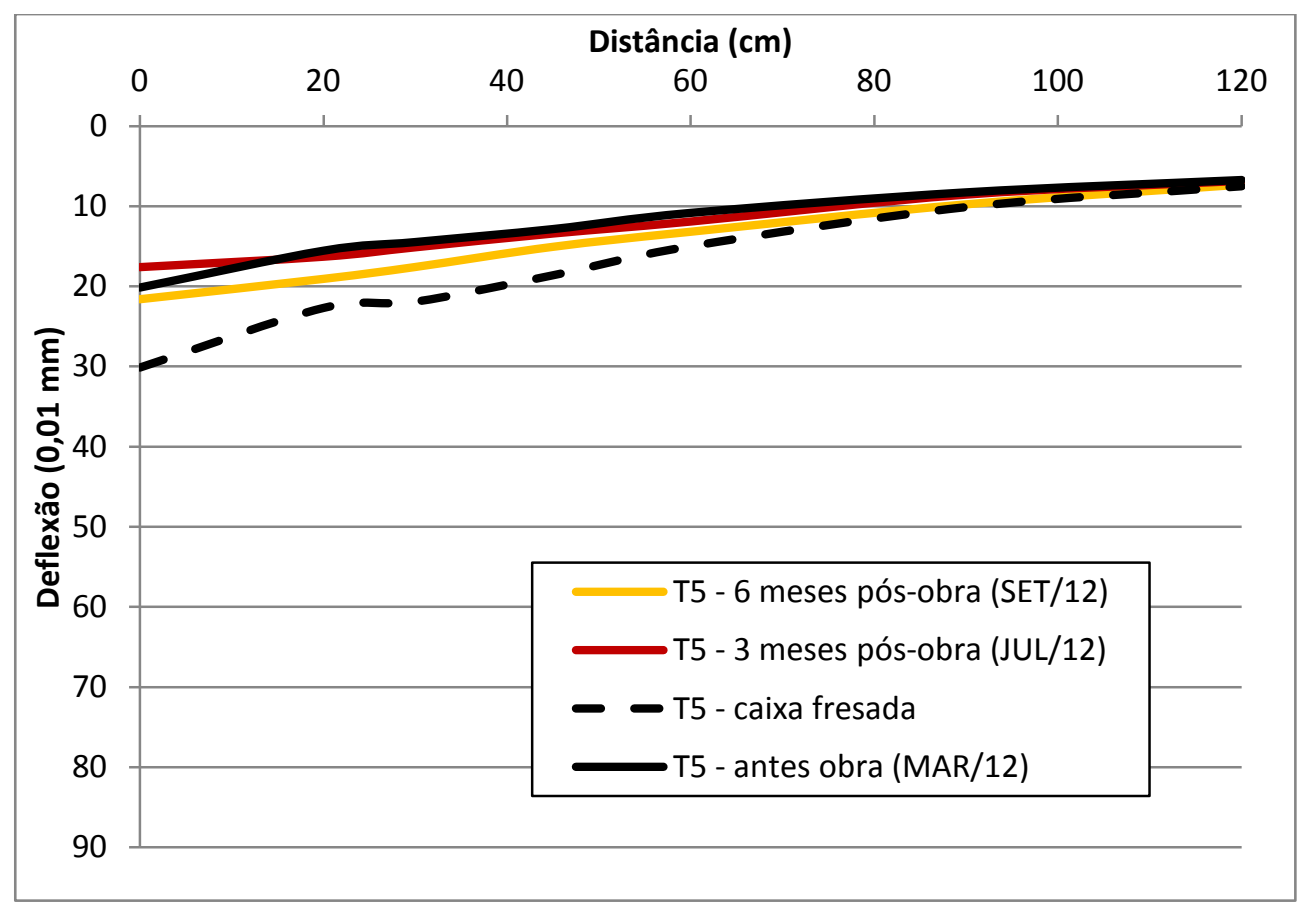

Figura 5.62 - Bacia de deflexão média do levantamento FWD para o trecho T5 (CBUQ sobre superfície fresada com grelha na interface) 


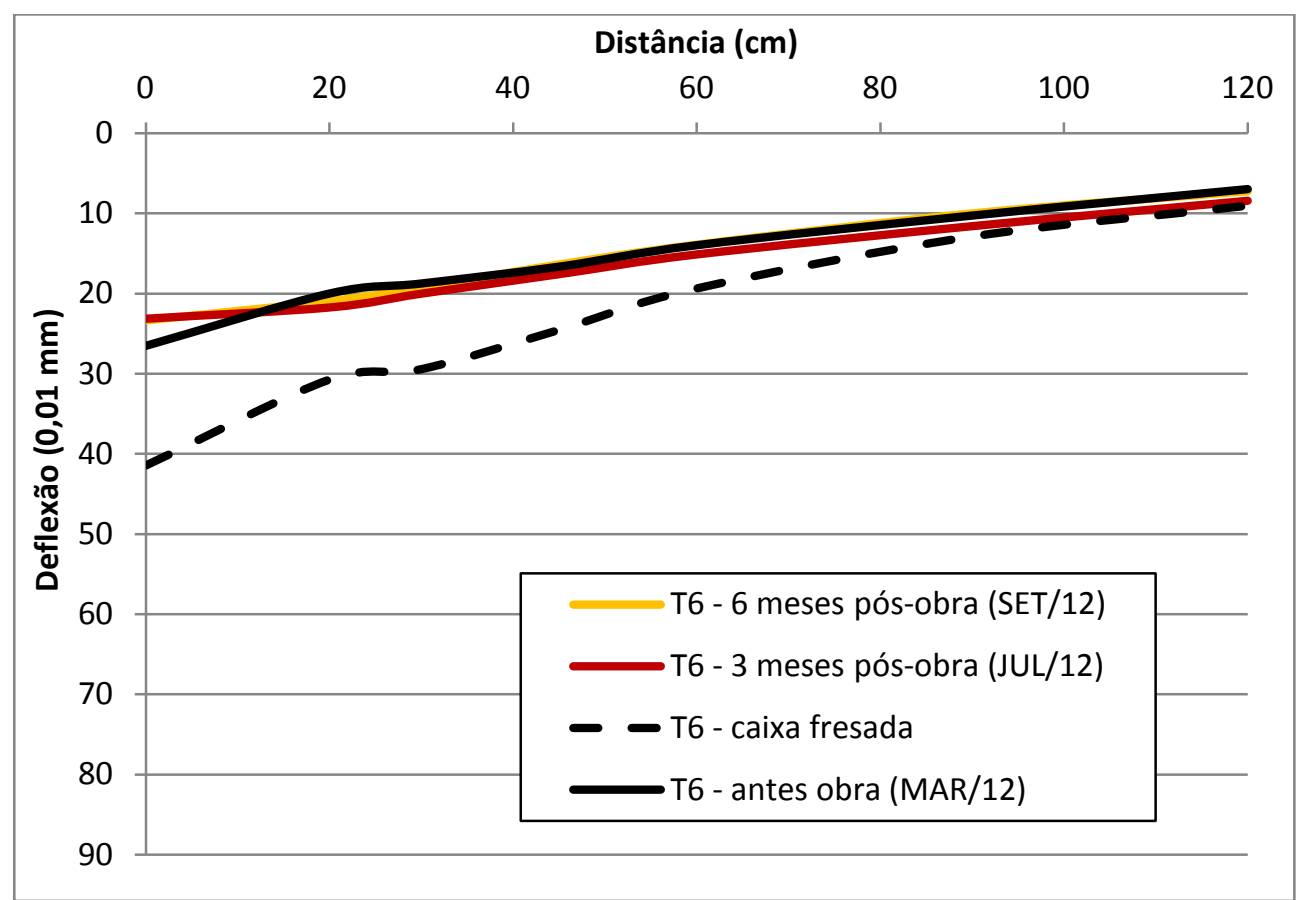

Figura 5.63 - Bacia de deflexão média do levantamento FWD para o trecho T6 (CBUQ sobre superfície fresada com pintura de ligação na interface)

A partir das figuras apresentadas, pode-se observar que os segmentos T3 e T4 apresentaram, no levantamento executado após 6 meses queda no valor das deflexões, comparando-os com os resultados obtidos após 3 meses. A redução no valor das deflexões pode ser explicada pelas condições de saturação do subleito e demais camadas. De acordo com dados do Instituto Nacional de Metereologia (INMET), o período do primeiro levantamento (julho de 2012) foi particularmente chuvoso naquela região, com média mensal de $220 \mathrm{~mm}$ de precipitação em junho. Durante o segundo levantamento (setembro de 2012) a região encontrava-se em período de seca com precipitação média mensal de $0 \mathrm{~mm}$ em agosto.

Para os segmentos T1 e T2, o resultado do segundo levantamento (6 meses) apresentou acréscimo significativo nos valores de deflexão máxima, mesmo em época de estiagem. Este pode ser um indicativo de que os segmentos já iniciaram um processo de deterioração, porém isso só poderá ser confirmado através de levantamentos posteriores.

Os segmentos T5 e T6 apresentaram valores semelhantes para ambos os levantamentos pós-obra ( 3 e 6 meses), estando ambos em um nível baixo de deflexão. 
Diante da variabilidade obtida nos levantamentos deflectométricos e, considerando que foram feitos apenas dois monitoramentos após a obra, sendo um em epóca de chuva e outro em estiagem, é necessário que sejam realizados novos levantamentos, para verificação do efeito do tráfego na evolução do processo de deterioração das diferentes soluções aplicadas no trecho experimental.

\subsubsection{Ensaio de cisalhamento direto Leutner}

Para que não houvesse grande interferência nos resultados devido a emendas e dificuldades construtivas, a retirada dos corpos de prova em campo foi feita desconsiderando os 10 primeiros e os 10 últimos metros de cada segmento. A princípio, foram feitas duas extrações por seção tipo (trechos T1 a T6), uma no eixo da pista e outra no bordo direito da pista, totalizando 12 amostras em cada campanha de extração. Na campanha de setembro (6 meses pós obra) extraíram-se 3 amostras por trecho visando aumentar a confiabilidade dos dados.

Os corpos de prova retirados em campo têm diâmetro de $100 \mathrm{~mm}$ e foram extraídos nas seguintes datas:

- Data 0 (abril de 2012), logo após a construção da obra, em período noturno (Figura 5.64);

- Data 1 (julho de 2012), 3 meses após início da obra, em período diurno, aproveitando o fechamento da pista para o levantamento FWD (Figura 5.66);

- Data 2 (setembro de 2012), 6 meses após início da obra, também em período noturno. 


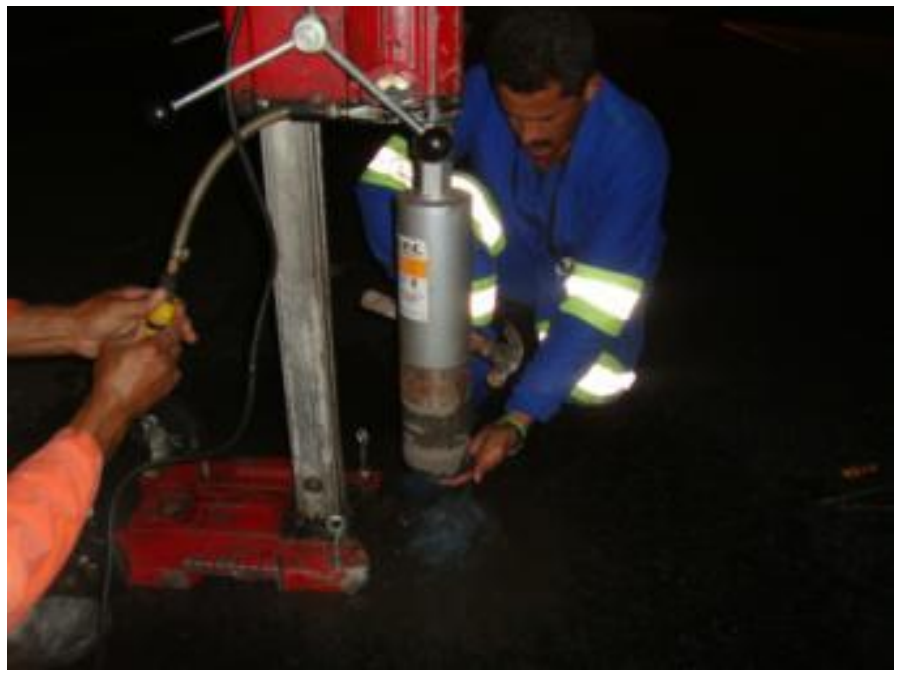

Figura 5.64 - Extração dos corpos de prova cilíndricos para ensaio de cisalhamento (abril de 2012)
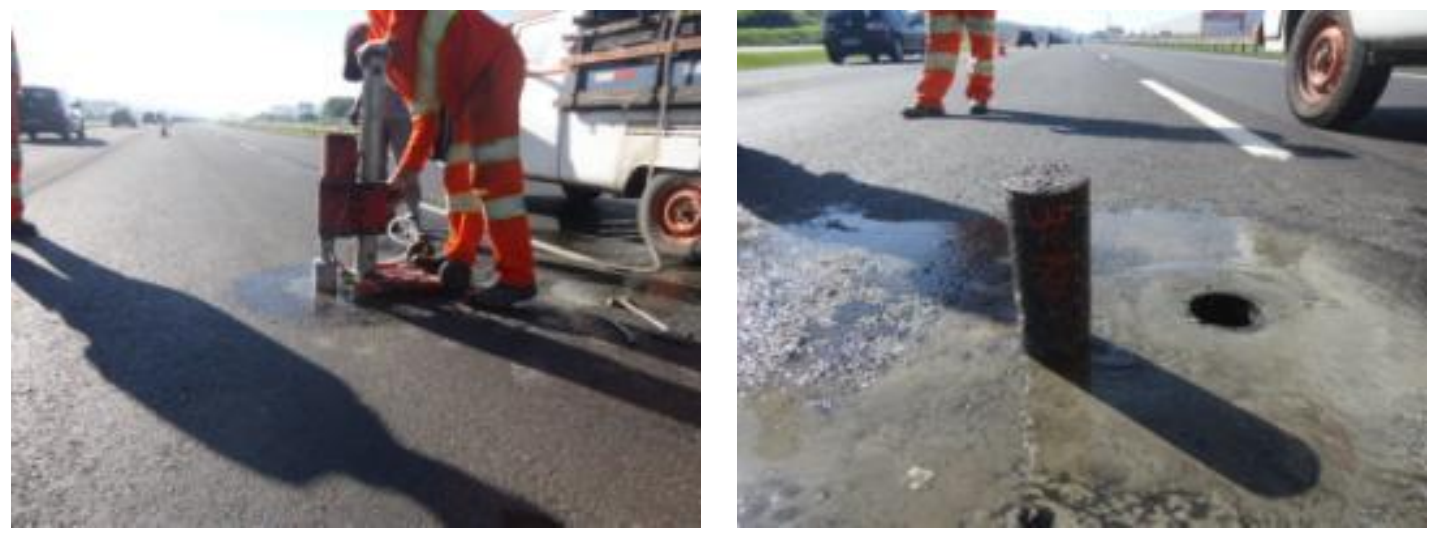

Figura 5.65 - Extração dos corpos de prova cilíndricos para ensaio de cisalhamento (julho de 2012)

Em laboratório, os CPs foram mantidos em câmara de controle de temperatura a $20^{\circ} \mathrm{C}$, por pelo menos 12 horas antes do ensaio de cisalhamento, e levados ao aparato de ensaio sem câmara, por se tratar de um procedimento com curto tempo de duração. A temperatura de $20^{\circ} \mathrm{C}$ é padronizada pela norma alemã do ensaio Leutner. $O$ ensaio foi realizado com velocidade constante de deslocamento da prensa hidráulica (810 Material Test System) igual a 50mm/min, ver Figura 5.66. 


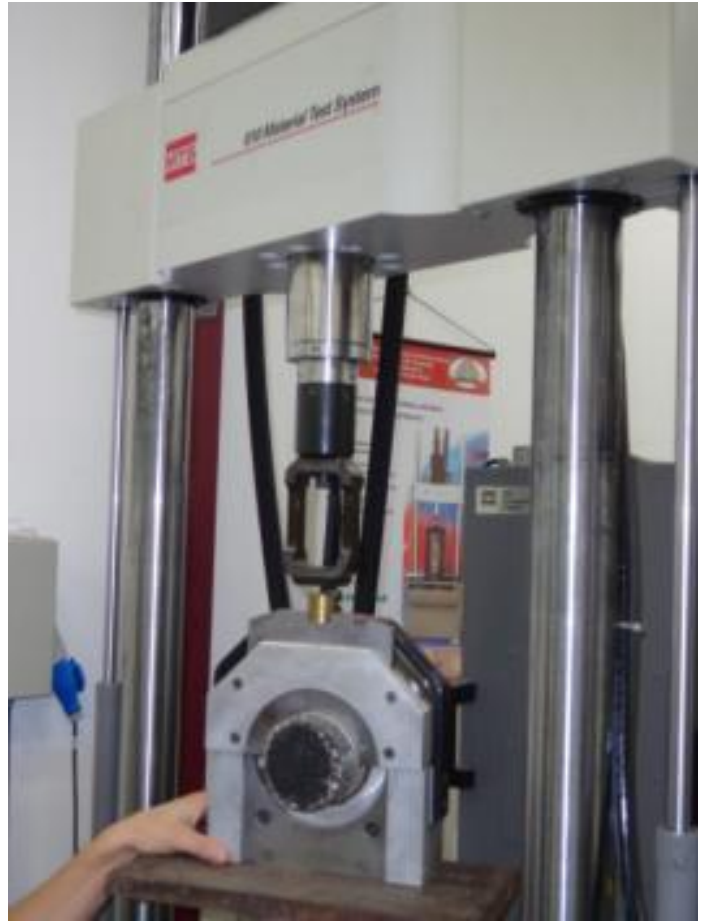

Figura 5.66 - MTS e aparato para realização do ensaio de cisalhamento Leutner

As Figuras 5.67 a 5.72 mostram exemplos das amostras em laboratório e a sequência de execução do ensaio de cisalhamento.

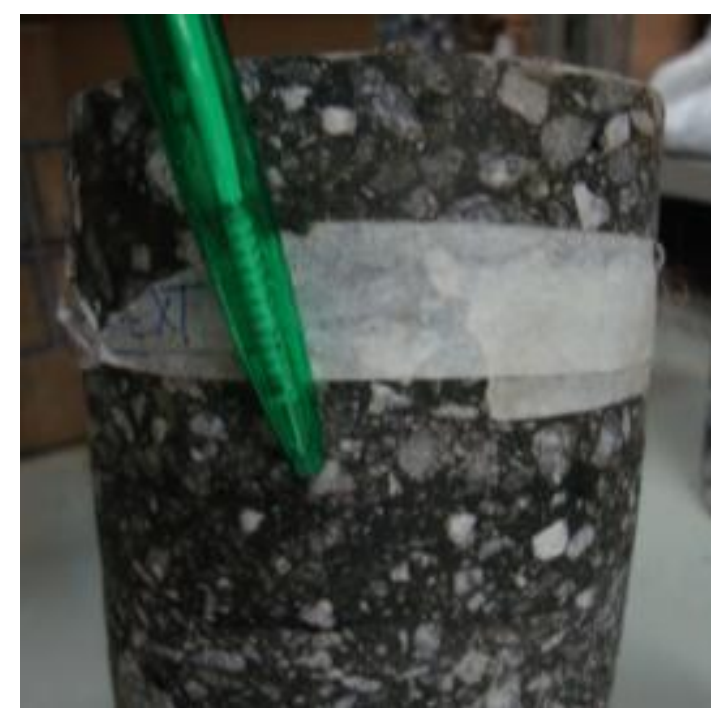

Figura 5.67 - CP antes de romper - Trecho T4 - Bordo direito da pista

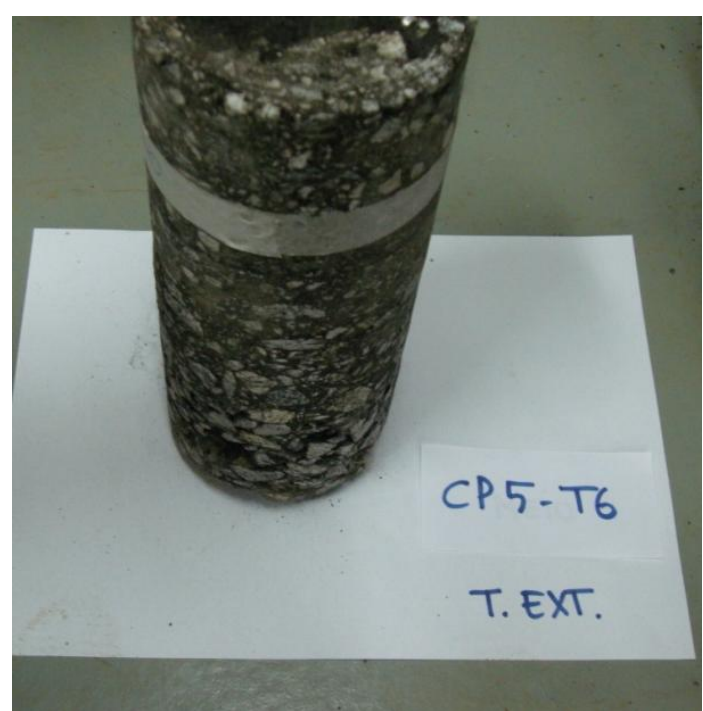

Figura 5.68 - CP antes de romper - Trecho T4 - Eixo da pista 


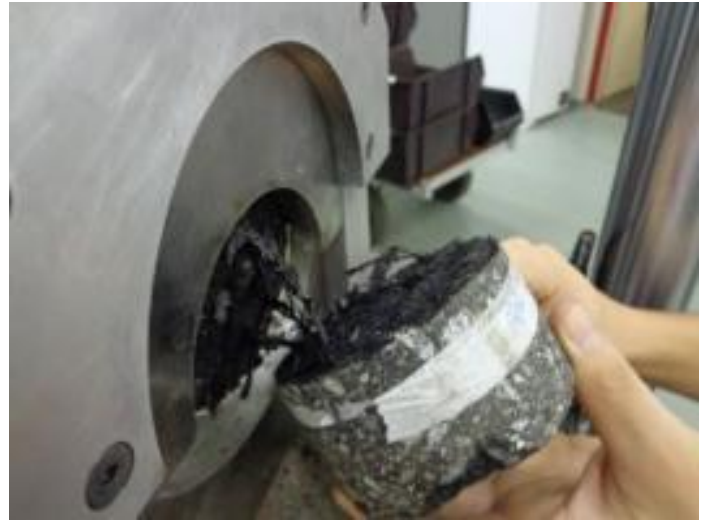

Figura 5.69 - Ruptura por cisalhamento Trecho T4 (SAMI+Grelha)

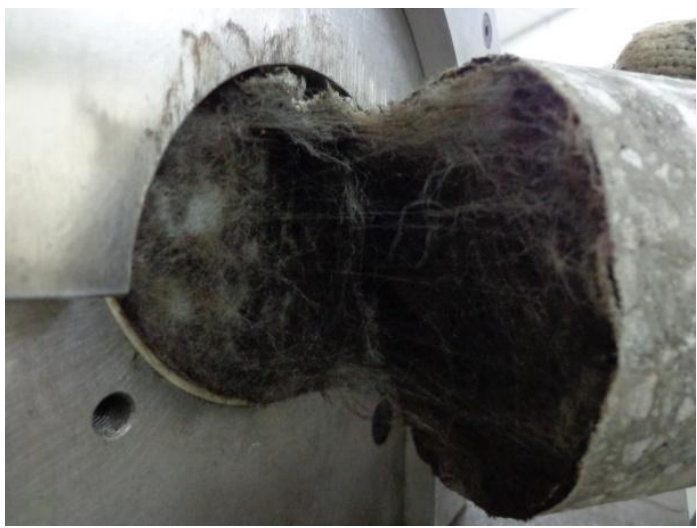

Figura 5.71 - Ruptura por cisalhamento Trecho T2 (SAMI+Geotêxtil)

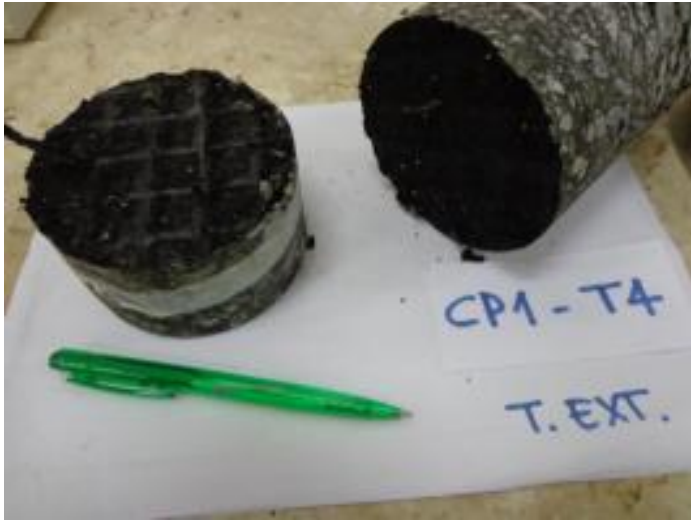

Figura 5.70 - Ruptura por cisalhamento Trecho T4 - Eixo da pista

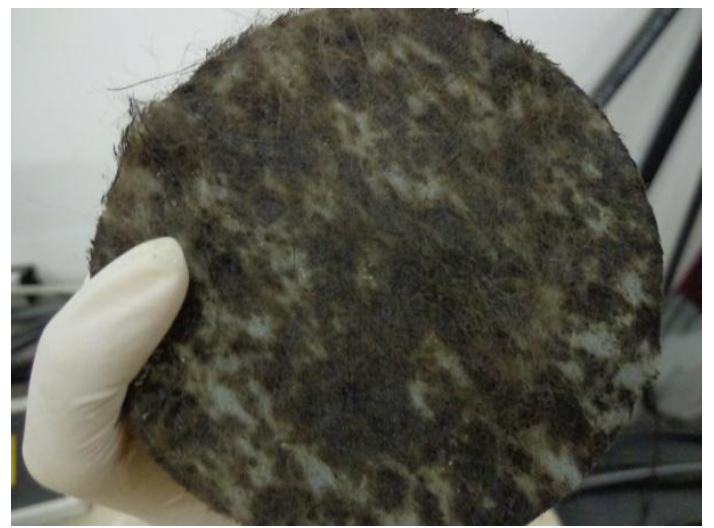

Figura 5.72 - llustração da pintura de ligação no geotêxtil de CP já rompido

Os resultados do ensaio de cisalhamento são apresentados na Tabela 5.2, em função das taxas de ligante residual aplicadas na pintura de ligação. Algumas amostras dos trechos com geotêxtil (T2 e T3), romperam durante a extração, ou durante o transporte para o laboratório (Figura 5.73). Outras amostras apresentaram delimitação irregular da interface entre camadas (Figura 5.74), que pode ter sido ocasionado por dificuldades executivas de compactação de uma camada uniforme e regular, o que dificultou a definição de um plano de ruptura. $O$ ensaio, nesses casos, resultou em valores de resistência ao cisalhamento na mistura, e não na interface entre camadas. Esses valores foram descartados durante a análise de dados. 


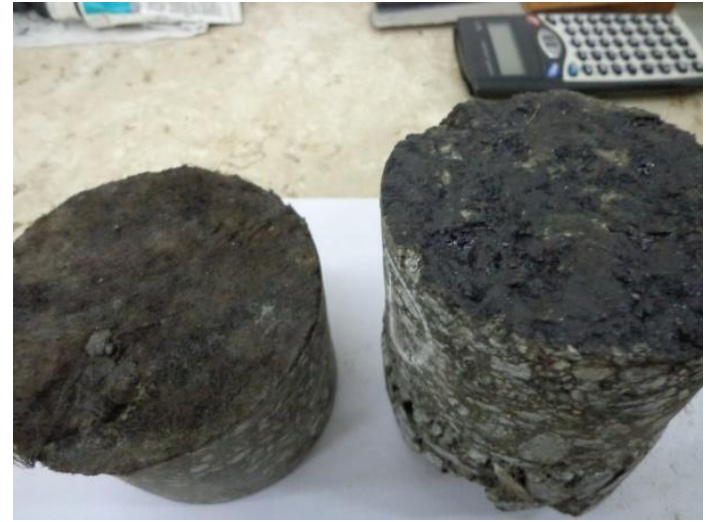

(a)

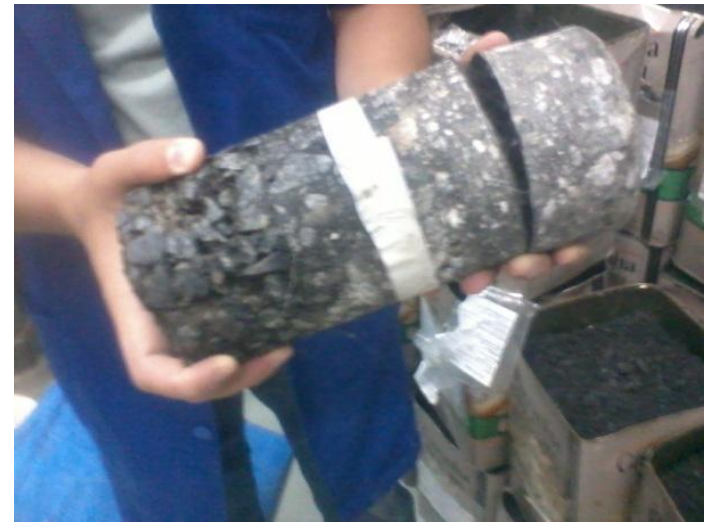

(b)

Figura 5.73 - Corpos de prova com geotêxtil rompidos (a) durante a extração em campo e (b) o transporte do campo ao laboratório

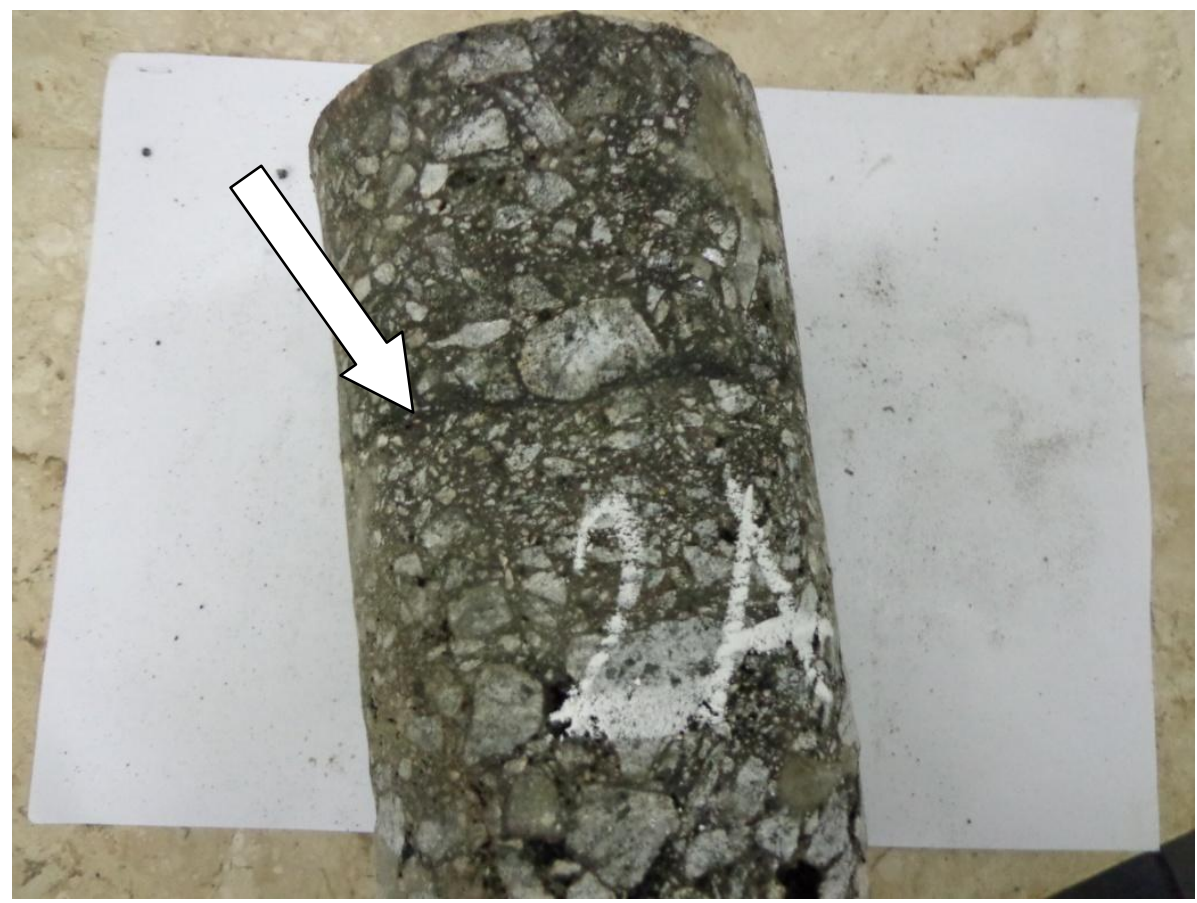

Figura 5.74 - Plano irregular de interface entre camadas 


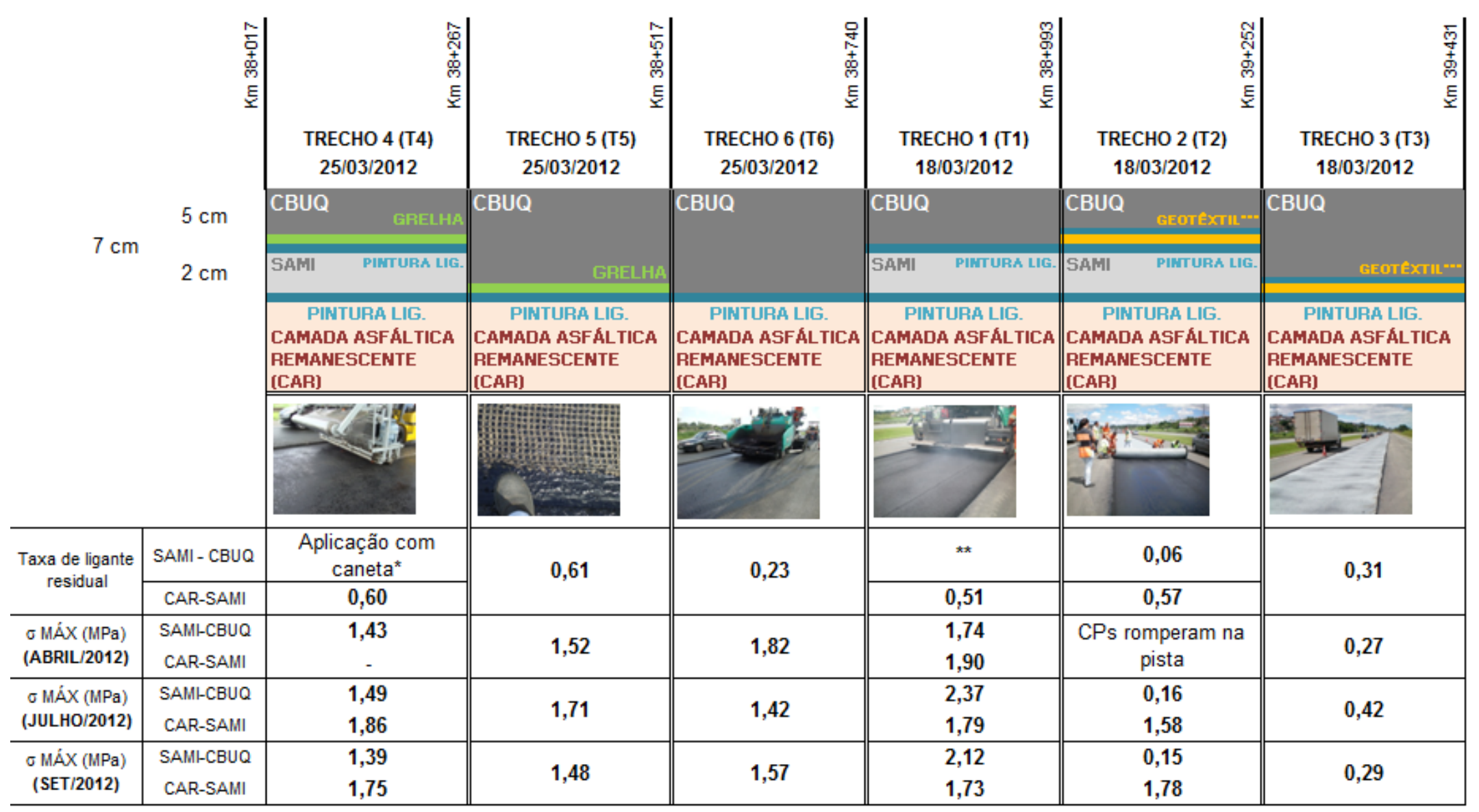

* No trecho T4 (SAMI+GRELHA), por solicitação do fabricante da grelha, aplicou-se emulsão com caneta. A taxa (baixa) neste caso não foi mensurada.

** A taxa de aplicação de emulsão no trecho T1 entre SAMl e CBUQ não foi medida durante a obra

*** Sobre o geotêxtil aplicou-se pintura de ligação com caneta.

Tabela 5.2 - Resumo dos resultados do ensaio de cisalhamento Leutner 
Dos resultados de tensão de cisalhamento obtidos em campo, percebe-se que a presença dos materiais de reforço anti-reflexão de trincas (geotêxtil e grelha) diminui a resistência ao cisalhamento (aderência) quando comparada às soluções que permitem contato direto e o intertravamento mecânico entre as camadas asfálticas. Para os casos com geotêxtil, trechos T2 e T3, percebe-se que, aliada à presença do material sintético, a baixa taxa de aplicação pode ter sido, ainda, fator comprometedor da aderência. Nos casos com grelha, a redução dos valores de tensão cisalhante máxima não é tão evidente, nem significativa. Um comparativo entre os trechos T4 e T5 permite perceber, ainda, que a baixa taxa aplicada com caneta no primeiro caso, correspondeu a valores mais baixos quando comparados ao segundo trecho, que teve aplicação com caminhão espargidor e taxa mais alta.

Não foi possível obter uma correlação entre os dados de tensão cisalhante máxima dos corpos de prova extraidos de pista e os levantamentos deflectométricos, visto que a estrutura remanescente apresentou-se variável ao longo do trecho. A variação do tipo de emulsão nos diferentes segmentos (T1, T2 e T3 com emulsão convencional; T4, T5 e T6 com emulsão modificada) também dificultou um comparativo entre as diferentes soluções.

Um comparativo pode ser realizado entre os resultados obtidos para 0 segmento T1 (SAMI+CBUQ e Emulsão 1) e as amostras moldadas em laboratório (Capítulo 4, Figura 4.7). Os resultados obtidos em campo, da ordem de 2,4 MPa em julho de 2012, foram inferiores aos valores obtidos em laboratório (3,5 MPa na taxa ótima de $0,15 \mathrm{~L} / \mathrm{m}^{2}$ de ligante residual). 


\section{CONSIDERAÇÕES FINAIS}

A aderência entre camadas asfálticas, e sua aplicação em projeto e obra, está intimamente ligada à durabilidade das soluções de recapeamentos, ou de pavimentos novos. Os estudos de aderência, desenvolvidos neste trabalho, contemplam a realização de ensaios de cisalhamento Leutner em amostras de dupla camada asfáltica, moldadas em laboratório e extraídas de um trecho experimental executado durante o desenvolvimento da pesquisa.

Da matriz de ensaios de laboratório, os resultados de resistência ao cisalhamento permitem concluir que:

- Há influência do tipo de emulsão utilizada (convencional ou modificada por polímero) na aderência entre camadas. Os maiores resultados de tensão cisalhante foram obtidos com a emulsão de maior viscosidade. Porém, esse parâmetro isolado não é suficiente para garantir boa aderência, já que uma das emulsões modificadas, também com alta viscosidade, resultou em valores menores quando comparados à emulsão convencional;

- Os resultados do ensaio de cisalhamento Leutner indicam a existência de uma taxa ótima de pintura de ligação e essa taxa é influenciada pelo tipo de emulsão. Ligantes residuais com maior viscosidade indicaram maior taxa ótima de aplicação;

- A presença de sistemas anti-reflexão de trincas na interface (geotêxtil e grelha) reduziu a aderência entre as camadas asfálticas. A queda nos valores de resistência ao cisalhamento foi mais pronunciada, porém, com o geotêxtil, que se configura como um material isolante entre as camadas e impede o intertravamento mecânico entre as superfícies asfálticas. Os resultados com geotêxtil ainda demonstraram influência no valor da taxa ótima, que aumentou em relação às amostras somente com pintura na interface. Os resultados com grelha não tiveram redução significativa nos valores de aderência, nem no valor da taxa ótima. Vale salientar que para ensaios com grelha na interface, a direção de 
cisalhamento mostrou-se um parâmetro relevante nos resultados. Com relação ao uso do geotêxtil entre camadas asfálticas como solução antireflexão de trincas, este deve ser avaliado com cautela não exatamente pelo aumento da taxa de aplicação de pintura de ligação, mas pelos reduzidos valores de tensão cisalhante máxima obtidos;

- A dimensão da amostra testada no ensaio de cisalhamento tem influência significativa nos resultados de aderência obtidos através do Leutner. Os corpos de prova com $100 \mathrm{~mm}$ de diâmetro resultaram em maiores valores de resistência ao cisalhamento quando comparados aos CPs de $150 \mathrm{~mm}$ de diâmetro. Acredita-se que exista uma maior concentração de tensões, inerentes do ensaio de cisalhamento, que são evidenciadas em amostras menores;

- A textura superficial das misturas asfálticas tem influência significativa na aderência entre camadas. Superfícies mais rugosas (maior macrotextura) apresentam maiores valores de aderência, devido ao intertravamento mecânico entre as camadas. O aumento de textura aumenta, além da tensão cisalhante máxima, a taxa ótima de aplicação de pintura de ligação.

Cabe ressaltar, ainda, as dificuldades encontradas para a realização do ensaio, principalmente no que tange à extração dos corpos de prova cilíndricos. Esses devem estar muito bem nivelados, permitindo a delimitação de um plano de cisalhamento bem definido e evitando que a ruptura ocorra na mistura e não na interface. Acredita-se que a aplicação de uma força normal ao plano de cisalhamento reduziria a variabilidade dos resultados obtidos no ensaio de cisalhamento direto Leutner.

Os resultados do monitoramento do trecho experimental obtidos indicam que:

- A baixa taxa de aplicação de pintura de ligação nos trechos com o geotêxtil, devido à dificuldade executiva, levou a resultados de aderência muito baixos e algumas amostras romperam ainda durante a extração, mostrando a grande importância da pintura ligação no comportamento da estrutura do pavimento; 
- Os resultados obtidos nos segmentos com grelha indicam que essa solução de reforço não reduziu de forma significativa os valores de tensão cisalhante máxima nos CPs extraídos de campo. Nos trechos onde houve aplicação da taxa de pintura de ligação com caneta, porém, os valores de aderência foram mais baixos quando comparados aos de aplicação com caminhão espargidor em taxas próximas a ideal. Recomenda-se, portanto, a não utilização da caneta como aplicação para pintura de ligação;

- Nos resultados do levantamento com o FWD percebe-se que os trechos que apresentavam valores mais elevados de deflexão antes da intervenção, continuam sendo os de deflexão mais altas. Todas as soluções de restauração investigadas, porém, encontram-se em condições aceitáveis estruturalmente, até a data de redação deste documento.

Os CPs de campo apresentam superfícies muito irregulares, devido a dificuldades de executar a camada asfáltica com espessura completamente uniforme e nivelada. 


\section{REFERÊNCIAS BIBLIOGRÁFICAS}

ABNT: ASSOCIAÇÃO BRASILEIRA DE NORMAS TÉCNICAS. NBR 12824:

Geotêxteis - Determinação da resistência à tração não confinada - Ensaio de tração de faixa larga - Método de ensaio. Rio de Janeiro, 1993, 5 p.

NBR 14896: Emulsões asfálticas modificadas com polímero Determinação do resíduo seco por evaporação. Rio de Janeiro, 2004.

NBR 14376: Emulsões asfálticas - Determinação do resíduo seco por evaporação - Método Expedito. Rio de Janeiro, 2007, 3 p.

BAE, A.; MOHAMMAD, L.N.; ELSEIFI, M.A.; BUTTON, J.; PATEL, N. Effects of Temperature on Interface Shear Strength of Emulsified Tack Coats and Its Relationship to Rheological Properties. Transportation Research Record: Journal of the Transportation Research Board, No. 2180, pp. 102-109, 2010.

Transportation Research Board of the National Academies, Washington, D.C., 2010.

BAHIA, H. U.; PERDOMO, D.; TURNER, P. Applicability of Superpave Binder Testing Protocols to Modified Binders. Transportation Research Record: Journal of the Transportation Research Board, No. 1586, pp. 16-23, 1997. Transportation Research Board of the National Academies, Washington, D.C., 1997.

BALBO, J. T. Pavimentação Asfáltica: materiais, projeto e restauração. Oficina de Textos, São Paulo, 2007.

BARKSDALE, R. D. The Aggregate Handbook. National Stone Association. Washington D.C., 1991.

BAZARRA, D.Z.; PERÉZ, M.C.; FRESNO, D.C.; ZAMANILLO, A.V. New procedure for measuring adherence between a geosynthetic material and a bituminous mixture. In: Geotextiles and Goemenbranes. 28. Elsevier. pp. 483-489. 2010.

BERNUCCI, L. B.; MOTTA, L. M. G.; CERATTI, J. A. P.; SOARES, J. B. Pavimentação Asfáltica - Formação Básica para Engenheiros. Rio de Janeiro, RJ. 2008.

BOGNACKI, C. J.; FRISVOLD, A.; BENNERT, T. Investigation of asphalt pavement slippage Failures on Runway 4R-22L, Newark International Airport. 
2007 FAA Worldwide Airport Technology Transfer Conference. Atlantic City, New Jersey, USA, 2007.

CALTRANS. Tack Coat Guidelines. Division of Construction California Departament of Transportation. State of California, 2009.

CHEN, J. ; HUANG, C. Effect of Surface Characteristics on Bonding Properties of Bituminous Tack Coat. Transportation Research Record: Journal of the Transportation Research Board, No. 2180, pp142-149, 2010. Transportation Research Board of the National Academies, Washington, D.C., 2010.

COLLOP, A.C.; THOM, N.H.; SANGIORGI, C. Assessment of Bond Condition using the Leutner Shear Test. In: PROCEEDINGS OF THE INSTITUTION OF CIVIL ENGINEERS. Volume 156 No. 4, pp. 211-217. Londres, 2003.

COLLOP, A.C.; SUTANTOA, M.H.; AIREYA, G.D.; ELLIOTTB, R.C. Shear Bond Strength between Asphalt Layers for Laboratory prepared Samples and Field Cores. Construction and Building Materials. Volume 23 Issue 6. 2009. PP. 2251-2258.

CORREIA, N. S. Comportamento de Geotêxteis Não Tecidos Impregnados com Emulsão Asfáltica usados como Aistema Anti-reflexão de Trincas. 2010.131 p. Dissertação (Mestrado) - Universidade de São Paulo. São Carlos, 2010.

COSTA, C. M. L.; LODI, P. C.; COSTA, Y. D. J.; BUENO, B. S. Avaliação de Recomendações Normativas sobre o Uso de Ensaios no Controle de Qualidade de Fabricação de Geossintéticos. Revista Polímeros: Ciência e Tecnologia, vol. 18, no 2, p. 158-169, 2008.

DER-SP: DEPARTAMENTO DE ESTRADAS DE RODAGEM DO ESTADO DE SÃO PAULO. ET-DE-P00/20 (2005) - Imprimação Betuminosa Ligante - Especificação Técnica - Departamento de Estradas de Rodagens do Estado de São Paulo, São Paulo, SP.

ET-P00/043 (2006) - Tratamento Anti-reflexão de Trincas com Geossintético - Especificação Técnica - Departamento de Estradas de Rodagens do Estado de São Paulo, São Paulo, SP.

DER-PR: DEPARTAMENTO DE ESTRADAS DE RODAGEM DO PARANÁ. ESP17/05 (2005) - Pavimentação: Pinturas Asfálticas - Especificação de Serviço Departamento de Estradas de Rodagens do Estado do Paraná. 
DIAKHATE, M.; PHELIPOT, A.; MILLIEN, A.; PETIT, C. Shear Fatigue Behaviour of Tack Coats in Pavements. In: Road Materials and Pavement Design 7. Gainesville, FL, 2005.

DNIT: DEPARTAMENTO NACIONAL DE INFRAESTRUTURA DE TRANSPORTES. ES-395/99 (1999) - Pintura de Ligação com Asfalto Polímero - Especificação de Serviço - Departamento Nacional de Infraestrutura de Transportes (antigo DNER). Instituto de Pesquisas Rodoviárias, Rio de Janeiro, RJ, 1999.

Manual de Restauração de Pavimentos Asfálticos - Publicação IPR-720 - Departamento Nacional de Infraestrutura de Transportes. Instituto de Pesquisas Rodoviárias, Rio de Janeiro, RJ, 2006.

. ES-144/2010 - Pavimentação Asfáltica: Imprimação com Ligante asfáltico convencional - Especificação de Serviço - Departamento Nacional de Infraestrutura de Transportes (antigo DNER). Instituto de Pesquisas Rodoviárias, Rio de Janeiro, RJ, 2010.

. ES-145/2010 - Pavimentação: Pintura de Ligação com Ligante Asfáltico Convencional - Especificação de Serviço - Departamento Nacional de Infraestrutura de Transportes (antigo DNER). Instituto de Pesquisas Rodoviárias, Rio de Janeiro, RJ.

EM 128/2010 - Emulsões Asfálticas Catiônicas Modificadas por

Polímeros Elastoméricos - Especificação de Material - Departamento Nacional de Infraestrutura de Transportes (antigo DNER). Instituto de Pesquisas Rodoviárias, Rio de Janeiro, RJ.

FIORIN, M. M. Avaliação de Desempenho de Recapeamentos Aslfálticos com camada Intermediária de Geotêxtil Submetidos à solicitação por simulador de tráfego. 2009. 106 p. Dissertação (Mestrado). Universidade Federal do Rio Grande do Sul, Porto Alegre, 2009.

HACHIYA, Y; SATO, K. Effect of Tack Coat on Bonding Characteristics at Interface Between Asphalt Concrete Layers. In: Eighth International Conference on Asphalt Pavements Proceedings, Vol. 1, 1997, pp. 349-362.

HUANG, Y. H. Pavement Analysis and Design. Prentice Hall, Upper Saddle River, New Jersey, 1993. 
KIM, Y. R.; LEE, Y.; LEE, H. Correspondence Principle for Characterization of Asphalt Concrete. In: Journal of Materials in Civil Engineering. Volume 7. American Society of Civil Engineers. 1995. pp. 59-68. Acesso em ascelibrary.org DOI: 10.1061/(ASCE)0899-1561(1995)7:1(59).

KRUNTCHEVA, M. R.; COLLOP, A. C.; THOM, N. H. Effect of Bond Condition on Flexible Pavement Performance. In: Journal of Transportation Engineering. 2005. pp. 880-888. Acesso em ascelibrary.org DOI: 10.106/(ASCE)0733947X(2005)131:11(880).

LAVIN, P.G. Asphalt Pavements. Spon Press, New York, 2003.

MOHAMMAD, L. N.; RAQIB, M.A.; HUANG, B. Influence of Asphalt Tack Coat Materials on Interface Shear Strenght. Transportation Research Record: Journal of the Transportation Research Board, No. 1789, pp56-65. Transportation Research Board of the National Academies, Washington, D.C., 2002.

MOHAMMAD, L. N.; BAE, A..; ELSEIFI, M.A.; BUTTON, J.; PATEL, N. Effects of Pavement Surface Type and Sample Preparation Method on Tack Coat Interface Shear Strenght. Transportation Research Record: Journal of the Transportation Research Board, No. 2180, pp93-101. Transportation Research Board of the National Academies, Washington, D.C. 2010.

MOHAMMAD, L. N.; ELSEIFI, M.A.; BAE, A.; PATEL, N.; BUTTON, J.; SCHEROCMAN, J. A. Optimization of Tack Coat for HMA Placement. NCHRP National Cooperative Highway Research Program. Report 712; Project 09-40. Transportation Research Board of the National Academies. Washington, D.C., 2012.

MONTESTRUQUE, G. Estudo de Sistemas Anti-reflexão de Trincas na Restauração de Pavimentos Asfálticos. 1996. Dissertação (Mestrado) - Instituto Tecnológico de Aeronáutica. São José dos Campos-SP, 1996.

MONTESTRUQUE, G. Contribuição para a Elaboração de Método de Projeto de Restauração de Pavimentos Asfálticos utilizando Geossintéticos em Sistemas Anti-reflexão de Trincas. 2002. 138p. Tese (Doutorado) - Instituto Tecnológico de Aeronáutica. São José dos Campos-SP, 2002.

MONTESTRUQUE, G.; VASCONCELOS, K. L.; BERNUCCI, L. L. B. Characterization of Interlayer Shear Resistance with the Use of Geogrid. In: 5th International Conference Bituminous Mixtures and Pavements. Thessaloniki, Greece, 2011. 
MUENCH, S.T.; MOOMAW, T. De-Bonding of Hot Mix Asphalt Pavements in Washington State: An Initial Investigation. Washington State Departament of Transportation. Final Technical Report. Office of Research \& Library Services. 2008. $51 \mathrm{p}$.

PAUL, P. E. Eliminating Delamination in Asphalt Overlays. In: HMAT - Hot Mix Asphalt Technology. Journal of the National Asphalt Pavement Association (NAPA), Volume 15, Number 3. Maio/Junho, 2010. pp. 16-17.

PAUL, H. R.; SCHEROCMAN, J. A. Friction Testing of Tack Coat Surfaces. Transportation Research Record: Journal of the Transportation Research Board, No. 1616, pp6-12. Transportation Research Board of the National Academies, Washington, D.C., 1998.

PINTO, Salomão. Materiais Betuminosos. Instituto Militar de Engenharia, Rio de Janeiro, 2008.

RAAB, C.; PARTL, M. N. Interlayer Shear Performance: Experience with Different Pavement Structures. In: 3ํ Eurasphalt \& Eurobitume Congress. Paper 081. Vienna, 2004. Book I - pp. 535-545.

RAPOSEIRAS, A.C.; ZAMANILLO, A.V.; PÉREZ, M.A.C.; FRESNO, D.C. Influence of Surface Macro-texture and Binder Dosage on the Adhesion between Bituminous Pavement Layers. Construction and Building Materials. 2012. No 28. pp. 187-192.

RECASENS, R. M.; MARTINÉZ, A.; PÉREZ JIMÉNEZ, F. Assessing Heat-adhesive Emulsions for Tack Coats. Proceedings of the Institution of Civil Engineers. Transport 158. 2005. pp. 45-51.

RECASENS, R.M.; MARTINEZ, A.; JIMÉNEZ, F.P. Evaluation of Effect of HeatAdhesive Emulsions for Tack Coats with Shear Test. Transportation Research Record: Journal of the Transportation Research Board, No. 1970, pp64-70. Transportation Research Board of the National Academies, Washington, D.C., 2006.

ROMANOSCHI, S. A.; METCALF, J. B. Characterization of Asphalt Concrete Layer Interfaces. Transportation Research Record: Journal of the Transportation Research Board, No. 1778, Transportation Research Board of the National Academies, Washington, D.C., 2001a, pp132-139. 
ROMANOSCHI, S. A.; METCALF, J. B. Effects of Interface Condition and Horizontal Wheel Loads on the Life of Flexible Pavement Structures. Transportation Research Record: Journal of the Transportation Research Board, No. 1778, Transportation Research Board of the National Academies, Washington, D.C., 2001b, pp123-131.

SANTAGATA, F.A.; FERROTTI, G.; PARTL, M. N.; CANESTRARI, F. Statistical Investigation of Two Different Interlayer Shear Test Methods. In: Materials and Structures. v:42 pp.705-714. 2009.

SALOMON, D. R. Asphalt Emulsion Technology. Transportation Research Circular E-C102. Transportation Research Board of The National Academies. Washington, D.C., 2006. 49p.

SHAHIN, M. Y.; KIRCHNER, K.; BLACKMON, E. W.; TOMITA, H. Effect of Layer Slippage on Performance of Asphalt Concrete Pavements. Transportation Research Record: Journal of the Transportation Research Board, No. 1095, Transportation Research Board of the National Academies, Washington, D.C., 1986, pp79-85.

SHOLAR, G. P.; MUSSELMAN, J. G.; UPSHAW, P.; MOSELEY, H. Preliminary Investigation of a Test Method to Evaluate Bond Strength of Bituminous Tack Coats. Proceedings of Association of Asphalt Paving Technologists. Volume 73. 2004. P. 771-801.

TASHMAN, L., NAM, K., PAPAGIANNAKIS, T. Evaluation of the Influence of Tack Coat Construction Factors on the Bond Strength between Pavement Layers. Washington State Department of Transportation. Final Report no WA-RD 645.1. Washington D.C., 2006.

UZAN, J.; LIVNEH, M.; ESHED, Y. Investigation of Adhesion Properties Between Asphaltic Concrete Layers. In: Proceedings of the Association of Asphalt Paving Technologists. Volume 47. Lake Buena Vista, FL, 1978. P. 495-521.

VAN CAUWELAERT, F. J.; ALEXANDER, D. R.; WHITE, T. D.; BARKER, W. R. Multilayer Elastic Program for Backcalculating layer moduli in pavement evaluation. In: Nondestructive Testing of Pavements and Backcalculation of Moduli. ASTM STP 1026, A. J. Bush III and G. Y. Baladi, Eds., American Society for Testing and Materials, Philadelphia, 1989. Pp. 171-188.

VANELSTRAETE, A. H. de Bondt, COURARD, L. Prevention of Reflective Cracking in Pavements. RILEM (Research Laboratories for Materials and Structures), 
Report 18. Edited by A. Vanelstraete and L. Francken. Belgian Road Research Centre, Brussels, Belgium, 1997.

VASCONCELOS, K. L; BERNUCCI, L.B.; MOURA, E.; SANBOUSUGE, K.; CHAVES, J. M. Caracterização Mecânica de Misturas Asfálticas Contínuas e Descontínuas com Diferentes Ligantes Asfálticos. In: $7^{\circ}$ Congresso Brasileiro de Rodovias e Concessões. Foz do Iguaçu. 2011.

WEST, R. C.; ZHANG, J.; MOORE, J. Evaluation of Bond Strength Between Pavement Layers. NCAT Report No. 05-08. National Center for Asphalt Technology. Auburn, A.L., 2005.

WICKERT F. Fatores de Influência no Comportamento de Camadas AntiReflexão de Trincas com Geossintéticos. 2003. Dissertação (Mestrado) - Instituto Tecnológico de Aeronáutica. São José dos Campos-SP, 2003.

ZIARI, H.; KHABIRI, M. M. Interface Condition Influence on Prediction of Flexible Pavement Life. In: Journal of Civil Engineering and Management. Vol XIII, No 1. 2007. pp. 71-76. 
ANEXOS - ESPECIFICAÇÃO DE MATERIAIS 
A. Emulsão asfáltica catiônica convencional de ruptura rápida (E1 : RR-1C)

Departamento Técnico:

\title{
INFORMAÇÕES IMPORTANTES
}

\begin{abstract}
A cada 5 dias não trabalhados a emulsão deve ser circulada dentro do tanque por 1:00h;
Em casos de pintura de ligação entrar em contato com o Departamento Técnico;

Tancagem deve ser limpa a cada 6 meses;

Manter agregados limpos, isentos de material argiloso ou pó aderido.
\end{abstract}

\begin{tabular}{|c|c|c|c|c|c|c|c|c|}
\hline \multicolumn{7}{|c|}{ CERTIFICADO DE QUALIDADE N N 1652} & \multicolumn{2}{|c|}{ DNER-EM 369/9 } \\
\hline \multirow{3}{*}{\multicolumn{2}{|c|}{ PRODUTO }} & \multirow{2}{*}{\multicolumn{2}{|c|}{ IDENTIFICAÇÄO }} & \multirow{2}{*}{$\begin{array}{l}N^{\circ} \text { DO } \\
\text { TANQUE }\end{array}$} & \\
\hline & & & & & \multicolumn{2}{|c|}{$\begin{array}{l}\text { FABRIC } \\
\text { DATA } \\
\end{array}$} & \multicolumn{2}{|c|}{ HORA } \\
\hline & & \multicolumn{2}{|c|}{ Emulsão Asfáltica Catiônica RR - 1C } & 10 & \multicolumn{2}{|c|}{ 09/01/2012 } & \multicolumn{2}{|c|}{$16: 40$} \\
\hline \multicolumn{9}{|c|}{ EMULSÃO ASFÁLTICA } \\
\hline \multirow{2}{*}{\multicolumn{4}{|c|}{ C ARACTERISTICAS }} & \multirow{2}{*}{\multicolumn{2}{|c|}{$\begin{array}{l}\text { MÉTODO } \\
\text { DE } \\
\text { ENSAIO }\end{array}$}} & \multirow{2}{*}{ 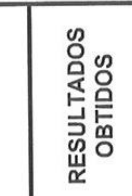 } & \multicolumn{2}{|c|}{$\begin{array}{c}\text { LIMITES } \\
\text { ESPECIFICADOS }\end{array}$} \\
\hline & & & & & & & 员 & $\sum_{\substack{x \\
\grave{x}}}^{0}$ \\
\hline \multirow{2}{*}{\begin{tabular}{l|}
0 \\
$\vdots$ \\
$\omega$ \\
1 \\
$\vdots$ \\
$\Sigma$ \\
\end{tabular}} & \multicolumn{2}{|c|}{ Viscosidade Saybolt Furol, a $50^{\circ} \mathrm{C}$} & s & \multicolumn{2}{|c|}{ NBR 14491} & 34 & 20 & 90 \\
\hline & \multicolumn{2}{|c|}{ Sedimentação, 5 dias peso max. por diferença } & $\%$ em peso & \multicolumn{2}{|c|}{ NBR 6570} & 1,12 & - & 5 \\
\hline 3 & \multicolumn{2}{|c|}{ Peneiramento, retido na peneira $0,84 \mathrm{~mm}$} & $\%$ em peso & \multicolumn{2}{|c|}{ NBR 14393} & 0 & - & 0,10 \\
\hline$\sum_{w}^{\Sigma} 4$ & \multicolumn{2}{|c|}{ Desmulsibilidade, \% peso } & $\%$ em peso & \multicolumn{2}{|c|}{ NBR 6569} & 56 & \multicolumn{2}{|c|}{50 mínimo } \\
\hline 5 & \multicolumn{2}{|c|}{ Resíduo asfáltico } & $\%$ em peso & \multicolumn{2}{|c|}{ NBR 14896} & 62,3 & 62 & - \\
\hline \multicolumn{9}{|c|}{ ATENÇÄO: Os resultados acima foram determinados através de ensaios realizados em amostras coletadas no tanque indicado. } \\
\hline \multicolumn{6}{|c|}{\begin{tabular}{|c|} 
OBSERVACOES ADICIONAIS \\
\end{tabular}} & \multicolumn{3}{|c|}{ EMISSAO DO CERTIFICADO } \\
\hline \multicolumn{6}{|c|}{$\begin{array}{l}\text { O recipiente do veículo transportador foi devidamente vistoriado. } \\
\text { A carreta segue lacrada. } \\
\text { A amostra deve ser coletada e lacrada na presença do cliente, ou } \\
\text { responsável. } \\
\text { Uma cópia do certificado deve ser entregue juntamente com a nota fiscal } \\
\text { e a outra deve retornar para CBB. }\end{array}$} & \multicolumn{3}{|c|}{$\begin{array}{l}\text { DATA:09/01/2012 } \\
\text { N.F.: } 5544 \\
\text { LACRES N } \\
\end{array}$} \\
\hline \multicolumn{9}{|c|}{ RESPONSÁVEIS TÉCNICOS } \\
\hline \multicolumn{4}{|c|}{$\begin{array}{l}\text { Eng. }{ }^{\circ} \text { Luiz Henrique Teixeira } \\
\text { CREA - 39735/D }\end{array}$} & \multicolumn{5}{|c|}{$\begin{array}{l}\text { Eng. }{ }^{\circ} \text { Vinícius Zózimo Cagliari } \\
\text { CRQ - } 09300075\end{array}$} \\
\hline
\end{tabular}

\begin{tabular}{|l|l|}
\hline IDENTIFICAÇÃO DA AMOSTRA: \\
\hline DATA DA COLETA: & 1109826 \\
\hline NO DO LACRE: & \\
\hline NOME LEGÍVEL E ASSINATURA DO MOTORISTA: & \\
\hline $\begin{array}{l}\text { NOME LEGÍVEL E ASSINATURA DO RESPONSÁVEL } \\
\text { PELO RECEBIMENTO: }\end{array}$ & \\
\hline
\end{tabular}

INFORMAÇÕES COMPLEMENTARES:

tecnico@cbbasfaltos.com.br

$41-99946173$ 


\section{B. Emulsão asfáltica catiônica de ruptura rápida modificada por polímero (E2 : RR-1C-E)}

Departamento Técnico:

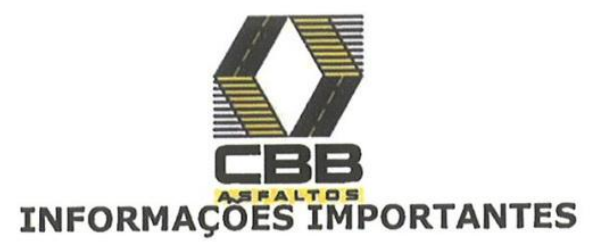

- A cada 5 dias não trabalhados a emulsão deve ser circulada dentro do tanque por 1:00h; - Tancagem deve ser limpa a cada 6 meses;

- Manter agregados limpos, isentos de material argiloso ou pó aderido.

CERTIFICADO DE QUALIDADE $\mathrm{N}^{\circ} 2035$

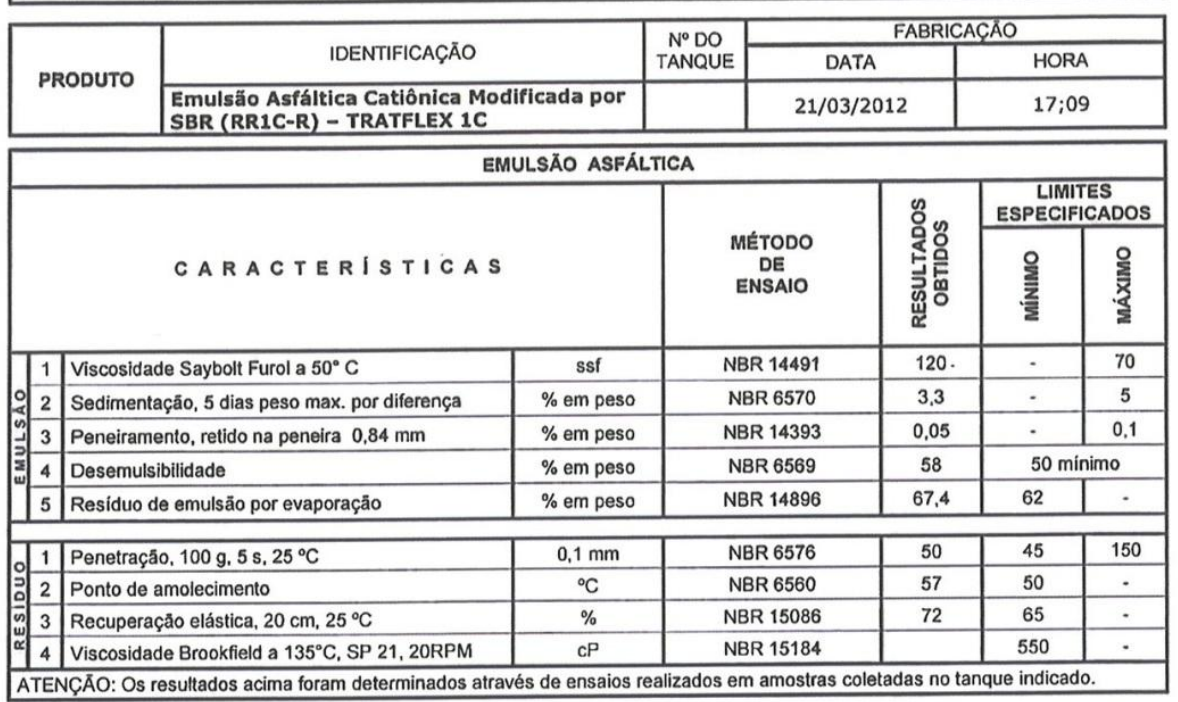

\begin{tabular}{|l|l|}
\hline \multicolumn{1}{|c|}{ OBSERVACOES ADICIONAIS } & \begin{tabular}{|l|}
\hline EMISSAO DO CERTIFICADO \\
\hline O recipiente do veículo transportador foi devidamente vistoriado. \\
A carreta segue lacrada. \\
A amostra deve ser coletada e lacrada na presença do cliente, ou \\
responsável. \\
Uma cópia do certificado deve ser entregue juntamente com a nota fiscal \\
e a outra deve retornar para CBB.
\end{tabular} \\
\hline
\end{tabular}

\begin{tabular}{|l|c|}
\hline \multicolumn{2}{|c|}{ RESPONSÁVEIS TÉCNICOS } \\
\hline $\begin{array}{c}\text { Eng. }{ }^{\circ} \text { Luiz Henrique Teixeira } \\
\text { CREA - 39735/D }\end{array}$ & $\begin{array}{c}\text { Eng. }{ }^{\circ} \text { Vinícius Zózimo Cagliari } \\
\text { CRQ - 09300075 }\end{array}$ \\
\hline
\end{tabular}

\begin{tabular}{|l|l|}
\hline \multicolumn{2}{|l|}{ IDENTIFICACÃO DA AMOSTRA: } \\
\hline DATA DA COLETA: \\
\hline N` DO LACRE: & 1655194 \\
\hline NOME LEGÍVEL. E ASSINATURA DO MOTORISTA: & \\
\hline $\begin{array}{l}\text { NOME LEGÍVEL. E ASSINATURA DO RESPONSÁVEL } \\
\text { PELO RECEBIMENTO: }\end{array}$ & \\
\hline
\end{tabular}

INFORMAÇÖES COMPLEMENTARES:

tecnico@cbbasfaltos.com,br

41- 99946173 


\section{Emulsão asfáltica catiônica de ruptura rápida modificada por polímero (E3: RR-2C-E)}

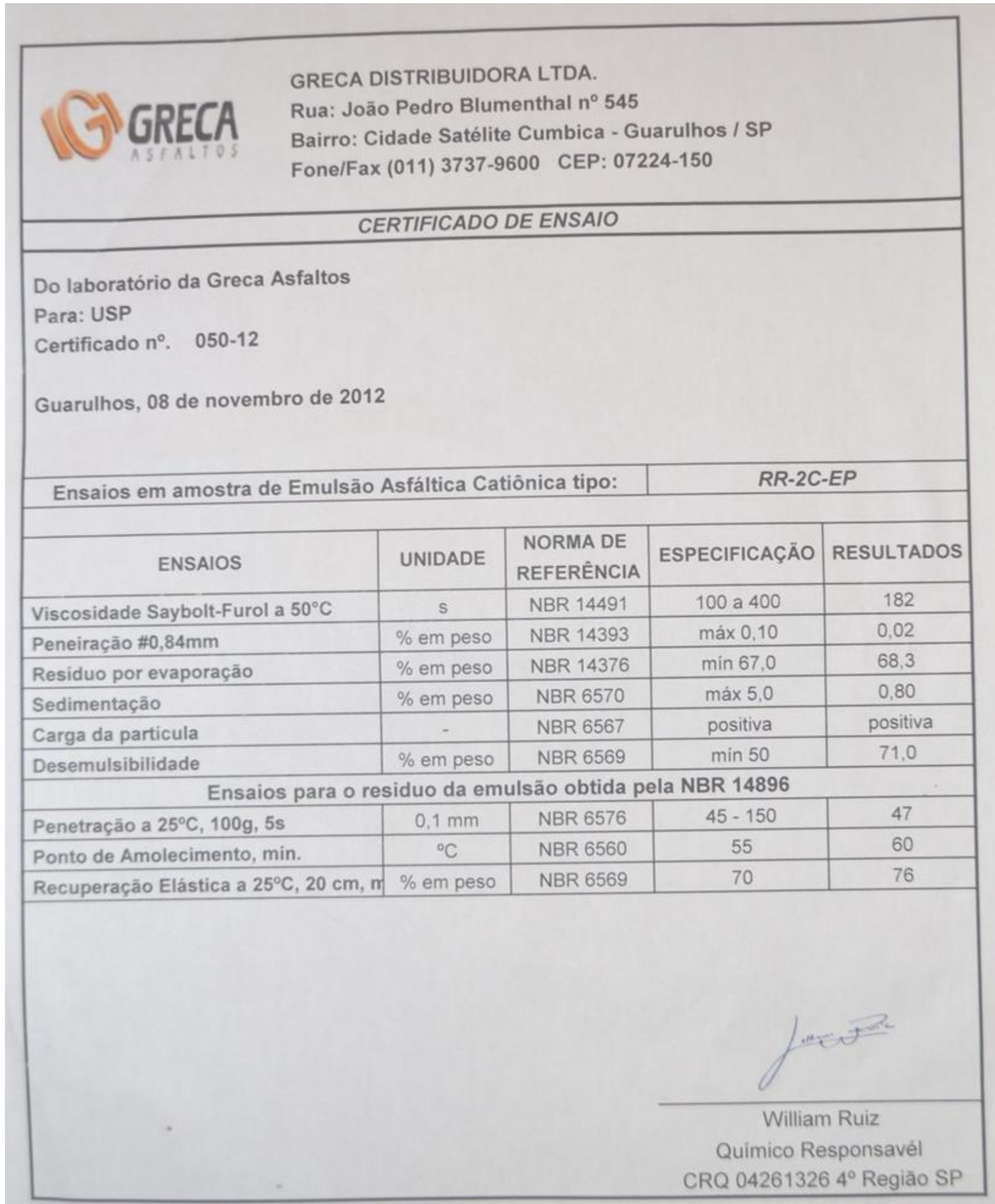




\section{Geotêxtil RT-10 (Bidim)}

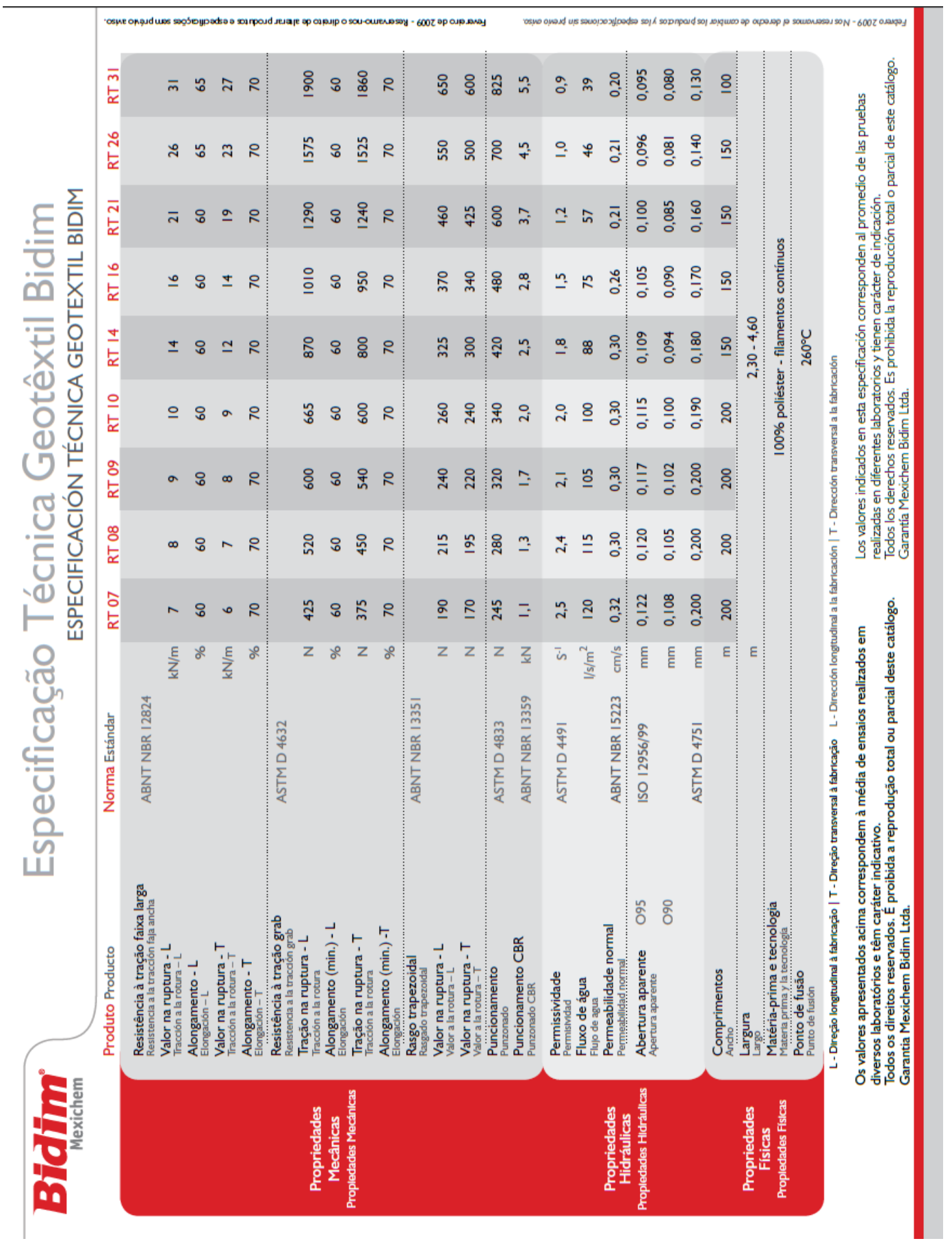




\section{E. Grelha de fibra de vidro (S\&P Reinforcement)}

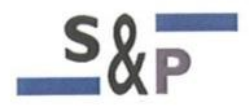

Clever Reinforcement Company AG

S\&P Glasphalt G (pre-bituminised asphalt reinforcement) can be applied to the entire surface or locally

\begin{tabular}{|c|c|c|}
\hline Technical data & $\begin{array}{l}\text { main } \\
\text { direction (MD) }\end{array}$ & $\begin{array}{l}\text { cross } \\
\text { direction (CD) }\end{array}$ \\
\hline \multicolumn{3}{|l|}{ Mechanical properties } \\
\hline Tensile modulus fibre roving & $73 ’ 000$ & $73 ’ 000$ \\
\hline Elongation at rupture fibre roving (\%) & $3.5-4.5$ & $3.5-4.5$ \\
\hline $\begin{array}{l}\text { Ultimate tensile force } \\
\text { (Test report: tbu 1.1/26564/0289.0.1-2008e, } \\
\text { EN ISO } 10319 \text { modified) }\end{array}$ & $\begin{array}{c}111(2.7 \%) \\
120 \text { (theoretical at failure } \\
\text { glass roving } 3.5 \%\end{array}$ & $\begin{array}{c}111(2.7 \%) \\
120 \text { (theoretical at failure } \\
\text { glass roving } 3.5 \%\end{array}$ \\
\hline
\end{tabular}

The theoretical tensile force bases upon the theoretical characteristic value of fibre guaranteed by its roving manufacturer.

Tack coat

(Recommendation by S\&P)

Remark: Different European coats resp. guidelines for asphalt pavement recommend for multilayer asphalts a shear bond $>15 \mathrm{kN}$ (method Leutner) resp. $>1.3 \mathrm{MPa}$ (pull off test).

This recommended shear bond will be achieved with S\&P Glasphalt G in praxis (Test reports are available). The positive result will be achieved without additional SAMI surface dressing on top of the asphalt reinforcement.
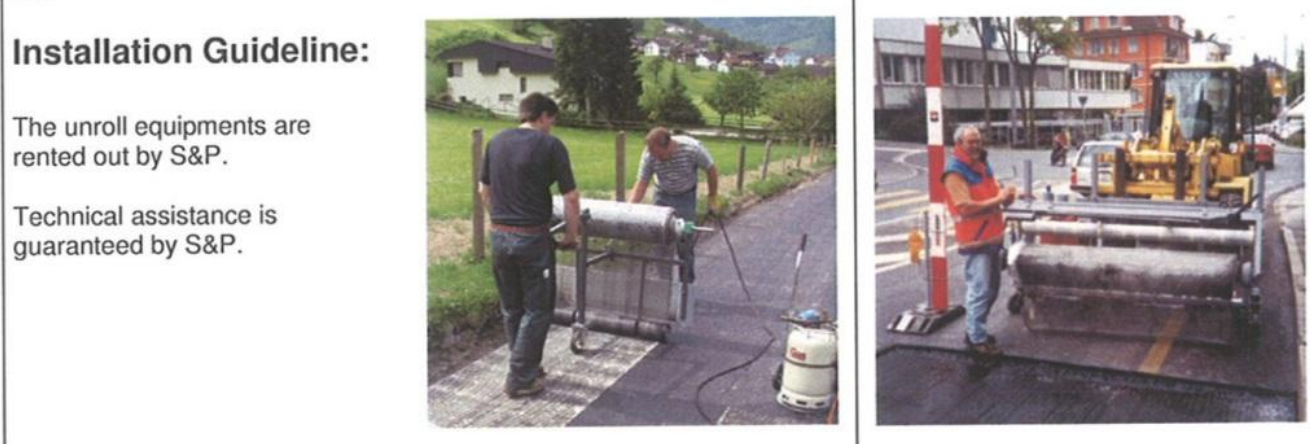

\begin{tabular}{|l|c|c|}
\hline Width of roll & $(\mathrm{m})$ & $0.97 / 1.95$ \\
\hline Length of roll & $(\mathrm{m})$ & 50 \\
\hline
\end{tabular}




\section{F. Ligante utilizado nas misturas de CBUQ}

Departamento Técnico:

\section{INFORMAÇÕES IMPORTANTES}

- Tancagem deve ser limpa a cada 6 meses;

- Manter agregados limpos, isentos de material argiloso ou pó aderido.

- Manter a temperatura quando em estocagem de $150^{\circ} \mathrm{C}$ a $163^{\circ} \mathrm{C}$;

DIARIAMENTE:

- Manter o nível do óleo dos agitadores na posição correta.

CONTROLE DE QUALIDADE No 1998

\begin{tabular}{|c|c|c|c|c|c|}
\hline \multirow{3}{*}{ PRODUTO } & IDENTIFICAÇÄO & No DO & FABRICAÇÄO & \multicolumn{2}{c|}{ COLETA DA AMOSTRA } \\
\cline { 2 - 5 } & Asfalto modificado com polímero & DANQUE & DATA & HORA \\
\cline { 2 - 6 } & POLIFLEX $\mathbf{6 0 / 8 5}$ & & $16 / 03 / 2012$ & $16 / 03 / 2012$ & $13: 25$ \\
\hline
\end{tabular}

\begin{tabular}{|c|c|c|c|c|c|c|c|}
\hline \multicolumn{8}{|c|}{ POLIFLEX $60 / 85$} \\
\hline \multirow{2}{*}{\multicolumn{4}{|c|}{ C ARACTERISTICAS }} & \multirow{3}{*}{$\begin{array}{c}\begin{array}{c}\text { MÉTODO } \\
\text { DE } \\
\text { ENSAIO }\end{array} \\
\text { NBR } 6576 \\
\end{array}$} & \multirow{3}{*}{$\begin{array}{c}\text { RESULTADOS } \\
\text { OBTIDOS }\end{array}$} & \multicolumn{2}{|c|}{ LIMITES } \\
\hline & & & & & & MíNIMO & MÁXIMO \\
\hline 1 & Penetração, $100 \mathrm{~g}, 5 \mathrm{~s}, 25^{\circ} \mathrm{C}, 0,1 \mathrm{~mm}$ & \multicolumn{2}{|r|}{$\mathrm{mm}$} & & & 40 & 70 \\
\hline 2 & Ponto de Fulgor & \multicolumn{2}{|r|}{${ }^{\circ} \mathrm{C}$} & NBR 11341 & 258 & 235 & - \\
\hline 3 & Ponto de Amolecimento & \multicolumn{2}{|r|}{${ }^{\circ} \mathrm{C}$} & NBR 6560 & 61 & 60 & 85 \\
\hline 4 & Recuperação Elástica, $20 \mathrm{~cm}, 25^{\circ} \mathrm{C}$ & \multicolumn{2}{|r|}{$\%$} & NBR 15086 & 87,5 & 85 & - \\
\hline 5 & Ductilidade a $25^{\circ} \mathrm{C}, 5 \mathrm{~cm} / \mathrm{min}$. & \multicolumn{2}{|r|}{$\mathrm{cm}$} & NBR 6293 & $>100$ & 100 & - \\
\hline \multirow{3}{*}{6} & \multirow{3}{*}{ Viscosidade Brookfield (cP) } & \multicolumn{2}{|c|}{$135^{\circ} \mathrm{C}$ - spindle $21,20 \mathrm{rpm}$} & \multirow{3}{*}{ NBR 15184} & 1637 & - & 3000 \\
\hline & & \multicolumn{2}{|c|}{$150^{\circ} \mathrm{C}$ - spindle $21,50 \mathrm{rpm}$} & & 748 & & 2000 \\
\hline & & \multicolumn{2}{|c|}{$177^{\circ} \mathrm{C}$ - spindle $21,100 \mathrm{rpm}$} & & 203 & - & 1000 \\
\hline 7 & $\begin{array}{l}\text { Ensaio de estabilidade a estocagem e } \\
\text { armazenagem ( } \neq \text { Topo e do Fundo). }\end{array}$ & \multicolumn{2}{|c|}{ Pto de amolec. ${ }^{\circ} \mathrm{C}$} & $\begin{array}{l}\text { NBR } 15166 \\
\text { NBR } 6560\end{array}$ & 4 & - & 5 \\
\hline \multicolumn{8}{|c|}{ ENSAIOS APÓS RTFOT } \\
\hline 8 & \multicolumn{2}{|l|}{ Variação em massa, máx. } & $\%$ & NBR 15235 & 0,6 & - & 1,0 \\
\hline 9 & \multicolumn{2}{|l|}{ Variação do Ponto de Amolecimento } & C & NBR 6560 & 7 & - & 9 \\
\hline 10 & \multicolumn{2}{|l|}{ Percentagem de Penetração Original } & $\%$ & NBR 6576 & 83 & 60 & - \\
\hline 11 & \multicolumn{2}{|c|}{ Percentagem de Rec. Elástica Original a $25^{\circ} \mathrm{C}$} & $\%$ & NBR 15086 & 94 & 80 & - \\
\hline
\end{tabular}
indicado.

\begin{tabular}{|c|l|}
\hline OBSERVACOES ADICIONAIS & EMISSAO DO CERTIFICADO \\
\hline PRODUTO ESTAGIADO NÃO DEIXAR LASTRO NA TANCAGEM & $\begin{array}{l}\text { NF.: 6114 } \\
\text { LACRES No 62201; 62207; 62236;. }\end{array}$ \\
\hline
\end{tabular}

\begin{tabular}{|c|c|}
\hline \multicolumn{2}{|c|}{ RESPONSÁVEIS TÉCNICOS } \\
\hline $\begin{array}{c}\text { Eng. }{ }^{\circ} \text { Luiz Henrique Teixeira } \\
\text { CREA - 39735/D }\end{array}$ & $\begin{array}{c}\text { Eng. }{ }^{\circ} \text { Vinícius Zózimo Cagliari } \\
\text { CRQ - 09300075 }\end{array}$ \\
\hline
\end{tabular}

\begin{tabular}{|l|l|l|l|l|l|l|}
\hline IDENTIFICAÇÃO DA AMOSTRA: & HORA: & $:$ & TEMPERATURA ( $\left.{ }^{\circ}\right)$ & & FROTA: \\
\hline DATA DA COLETA: & & & \\
\hline NOME LEGÍVEL E ASSINATURA DO MOTORISTA: & & \\
\hline $\begin{array}{l}\text { NOME LEGÍVEL E ASSINATURA DO RESPONSÁVEL } \\
\text { PELO RECEBIMENTO: }\end{array}$
\end{tabular}

INFORMAÇÕES COMPLEMENTARES: henrique@cbbasfaltos.com.br (41) - 99946173 


\section{G. Caracterização das misturas de CBUQ}

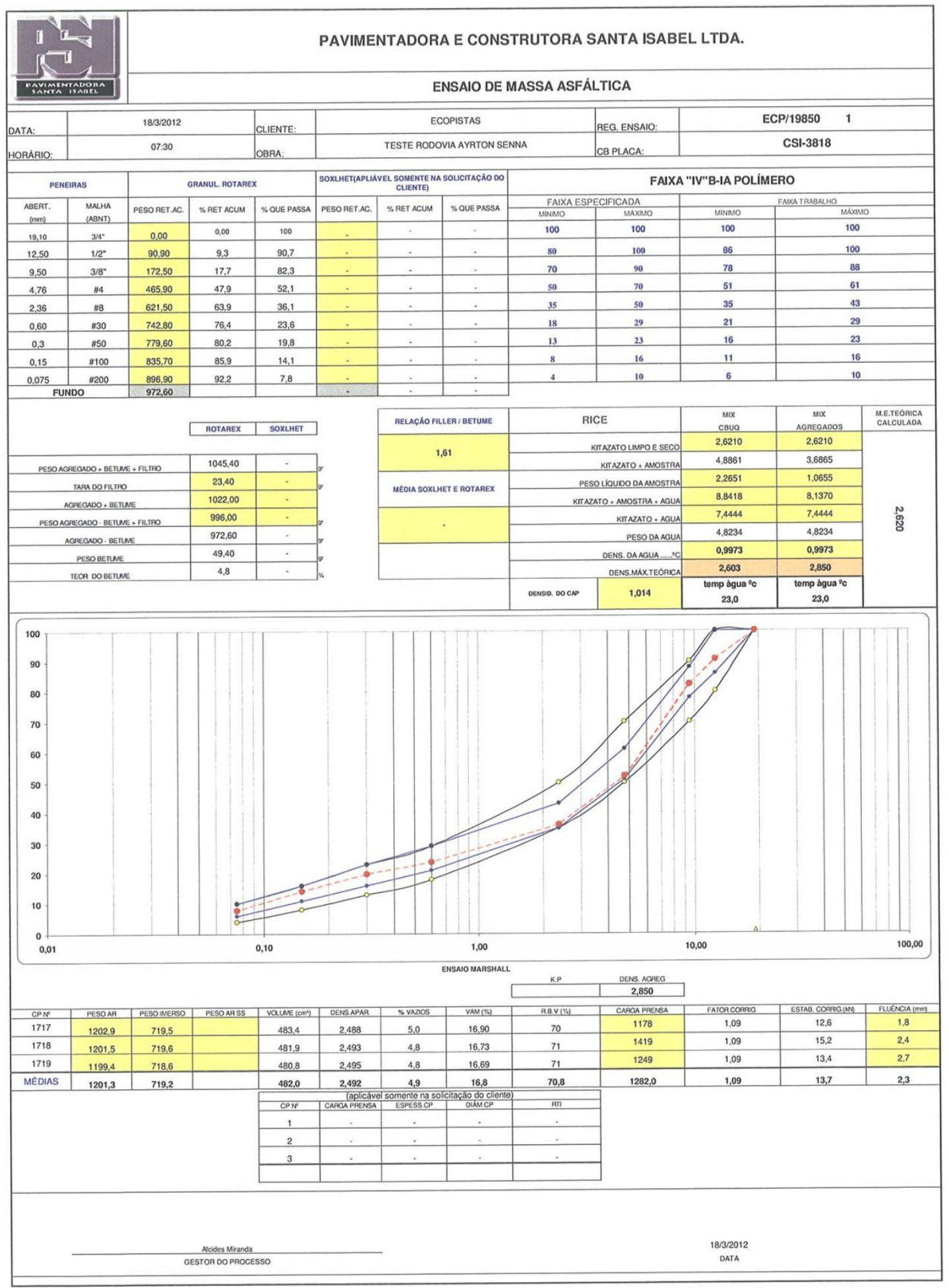




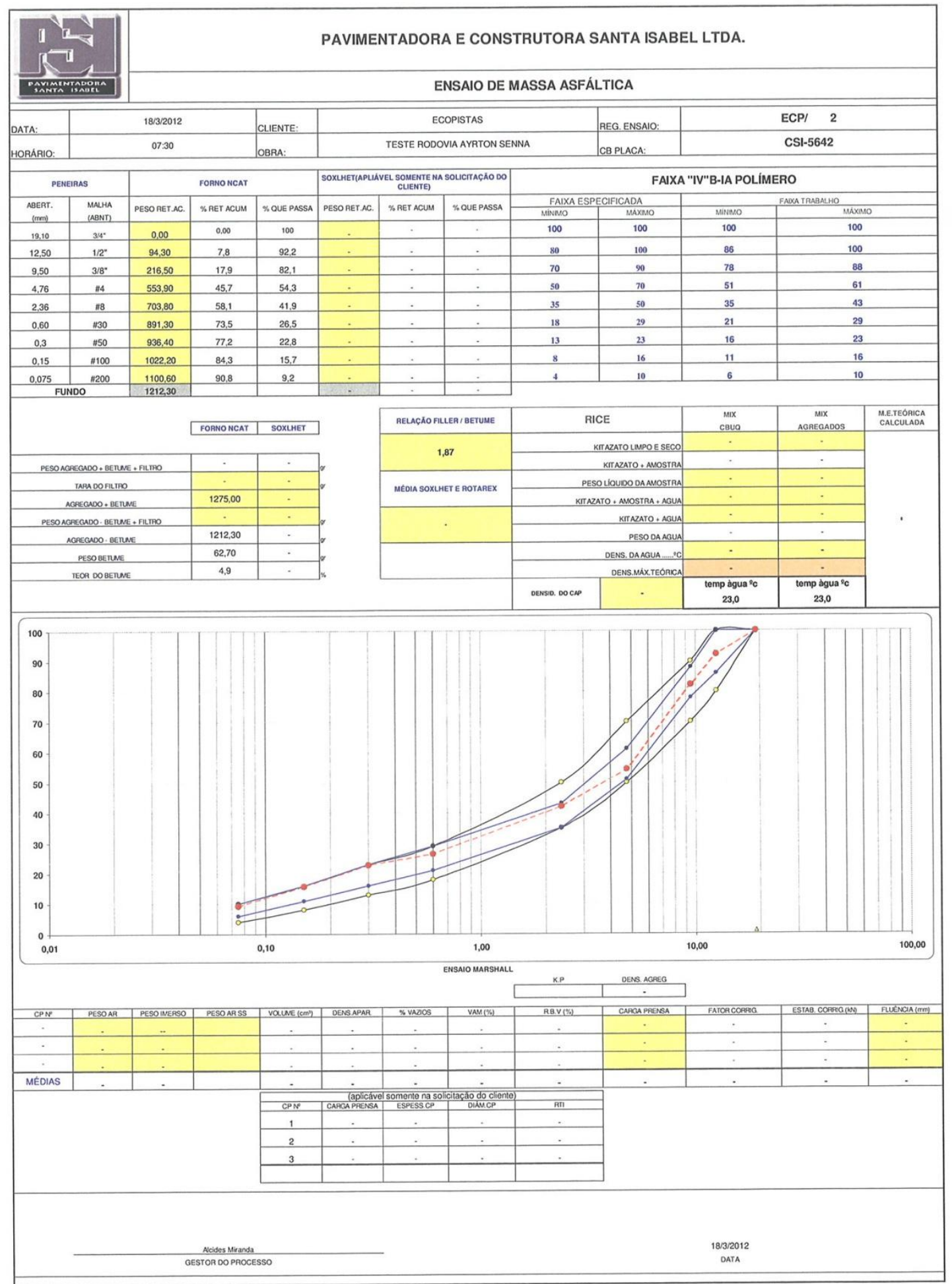




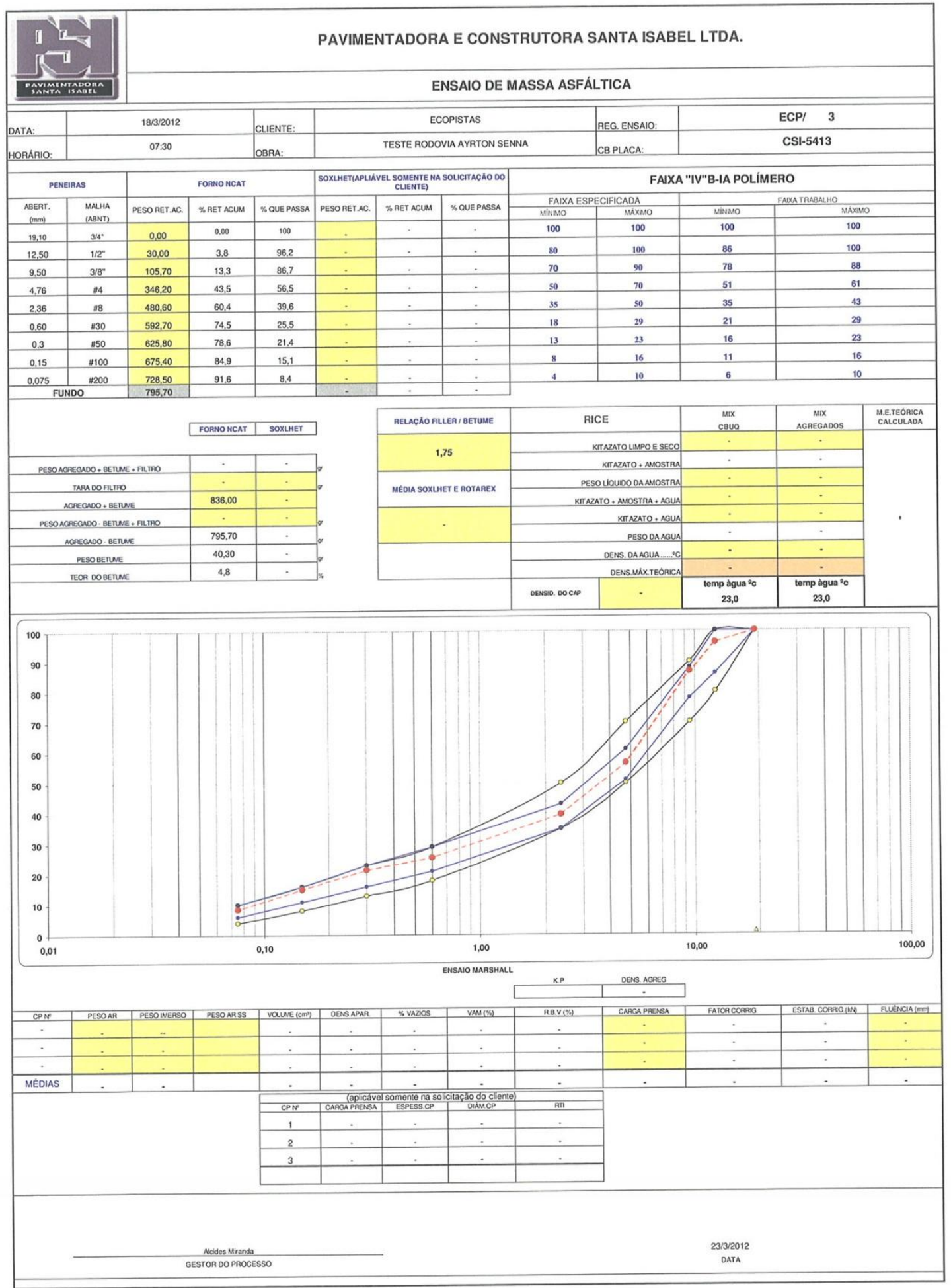




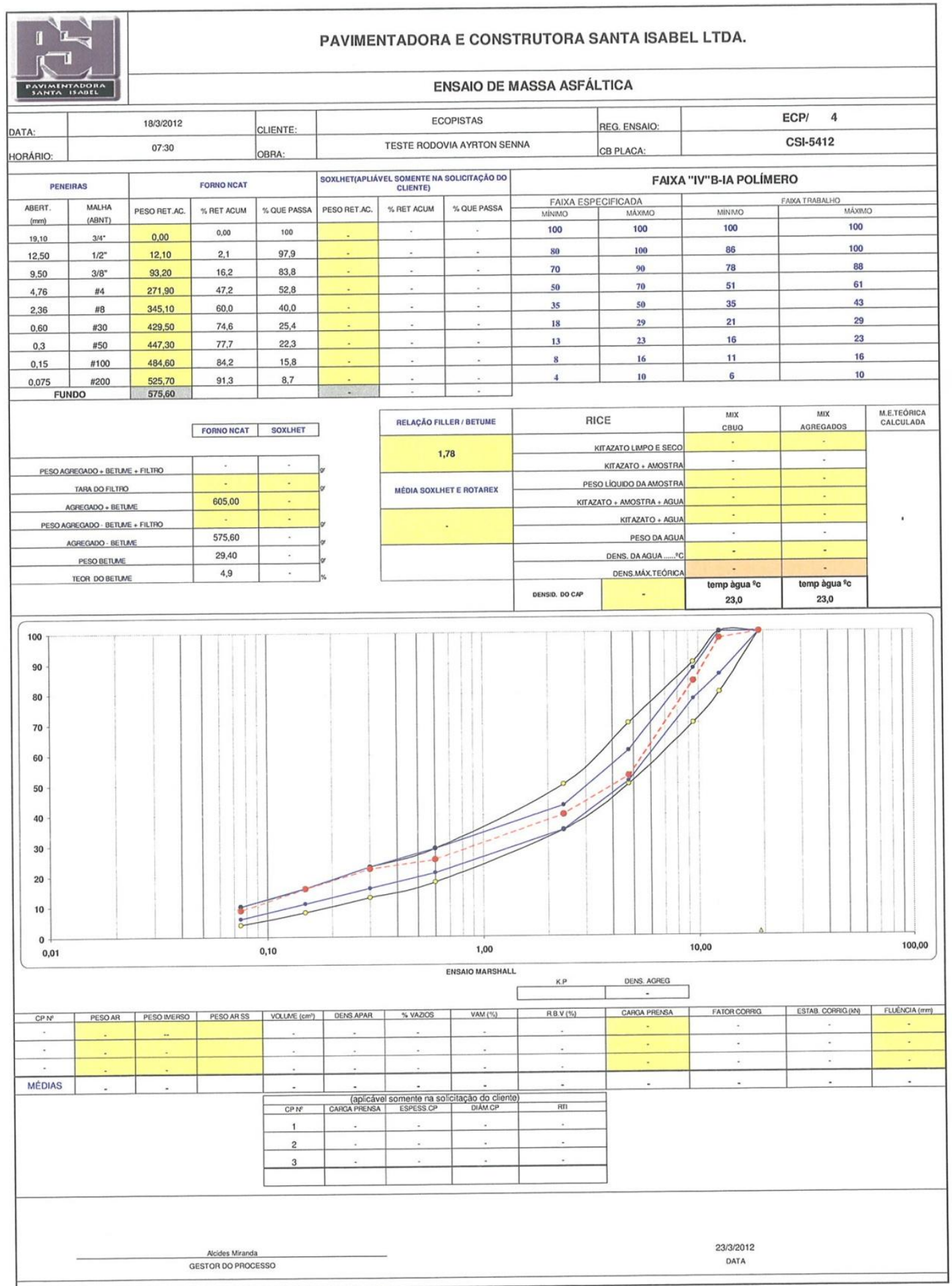




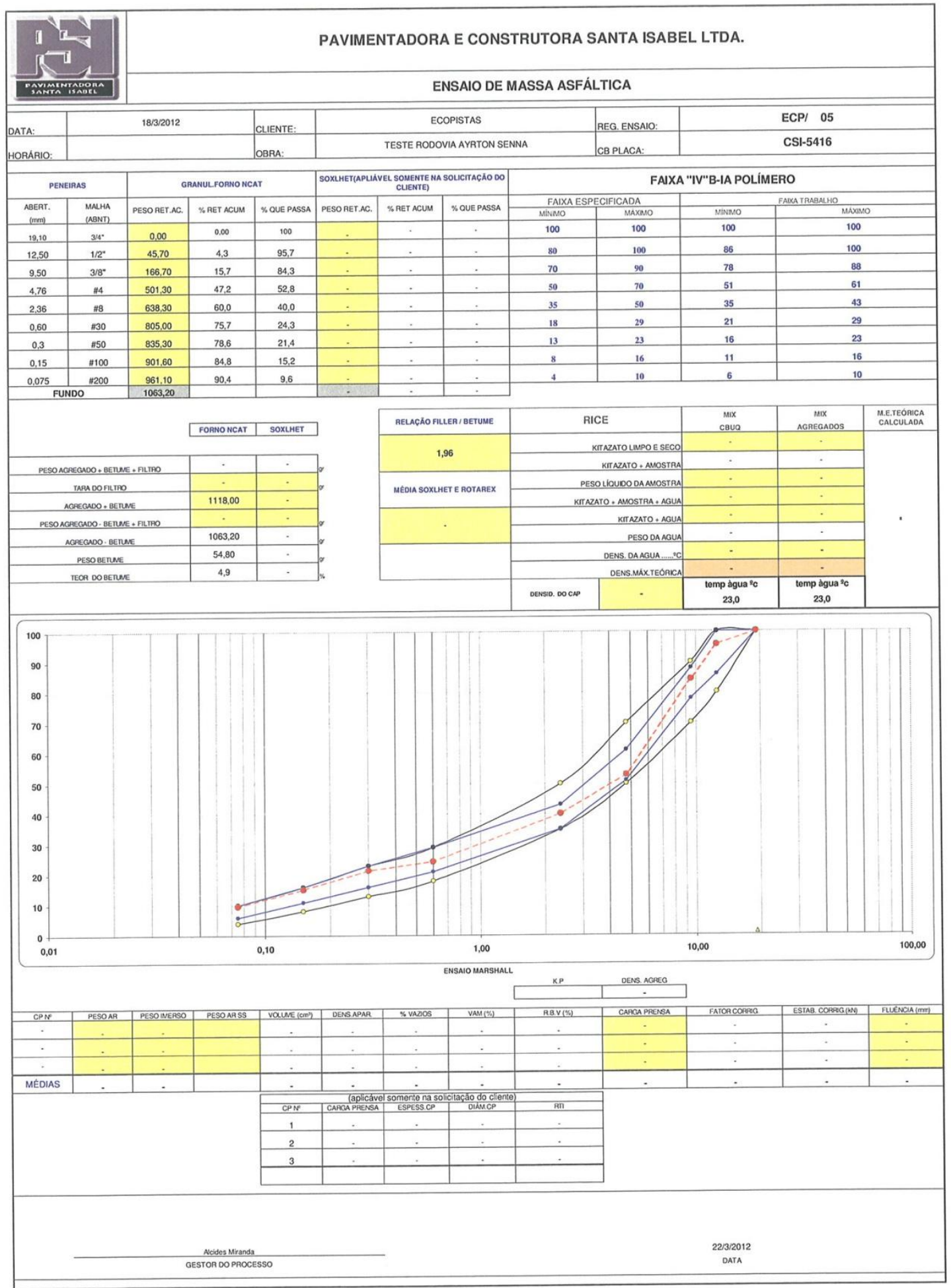




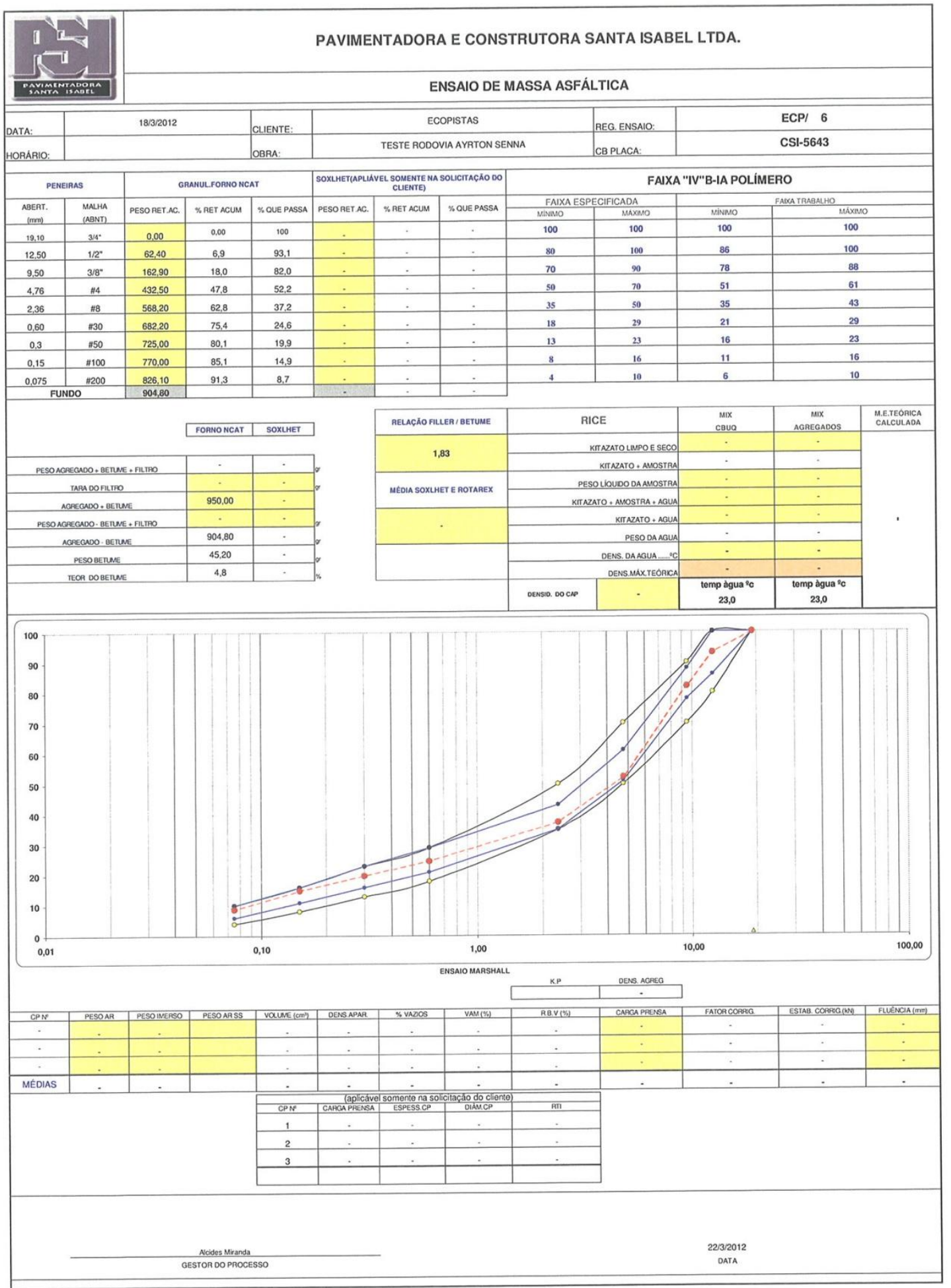




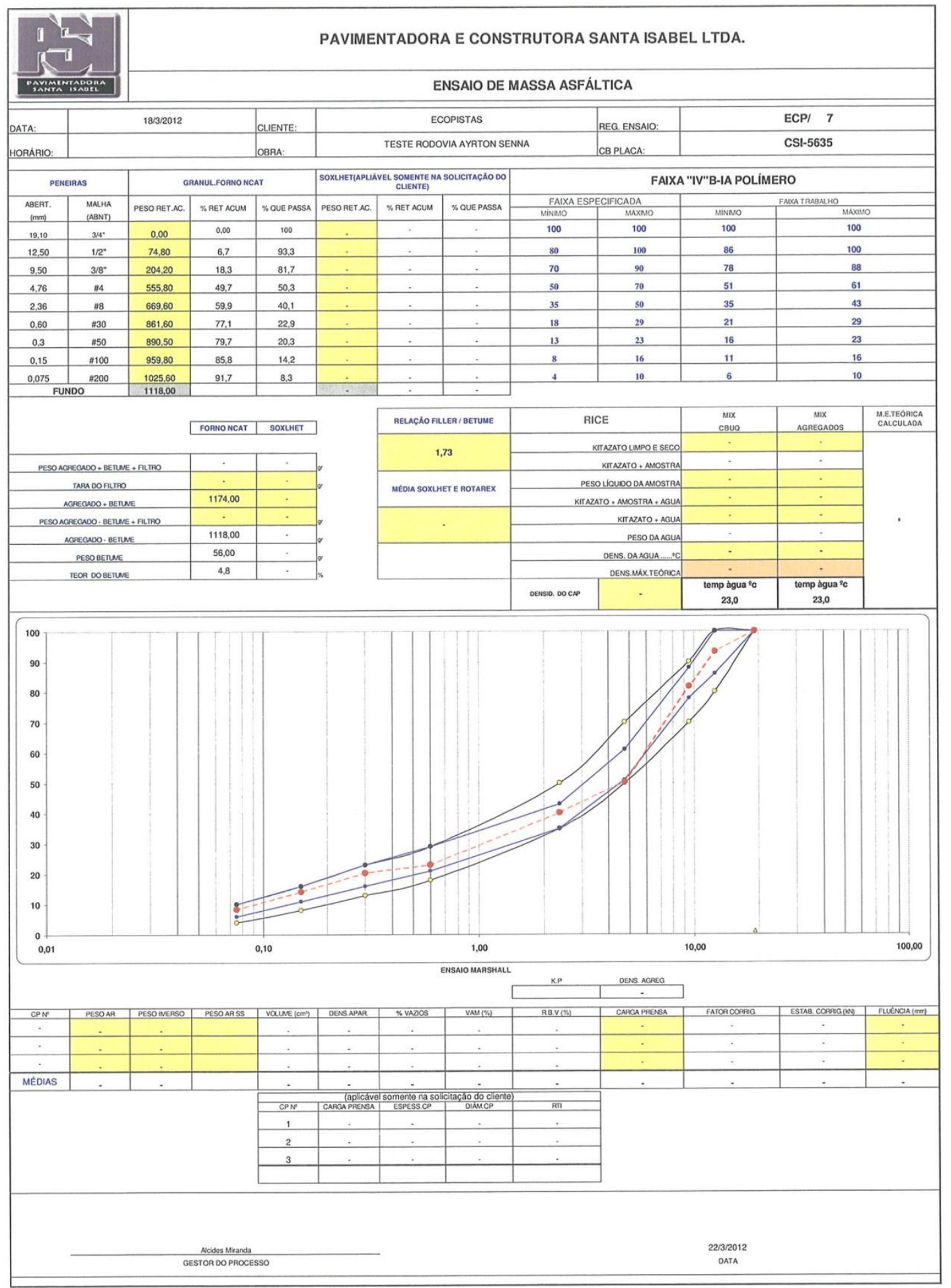




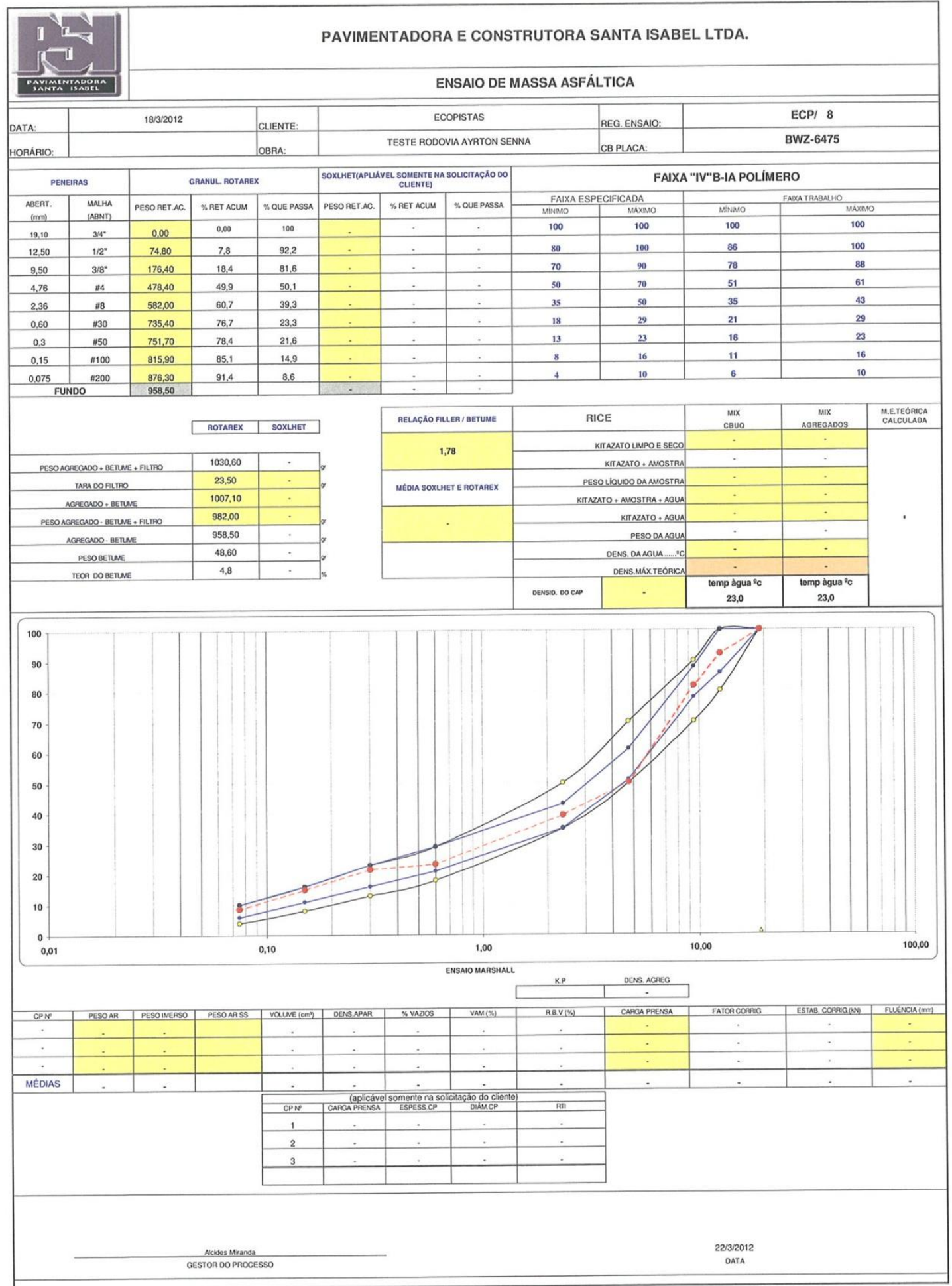




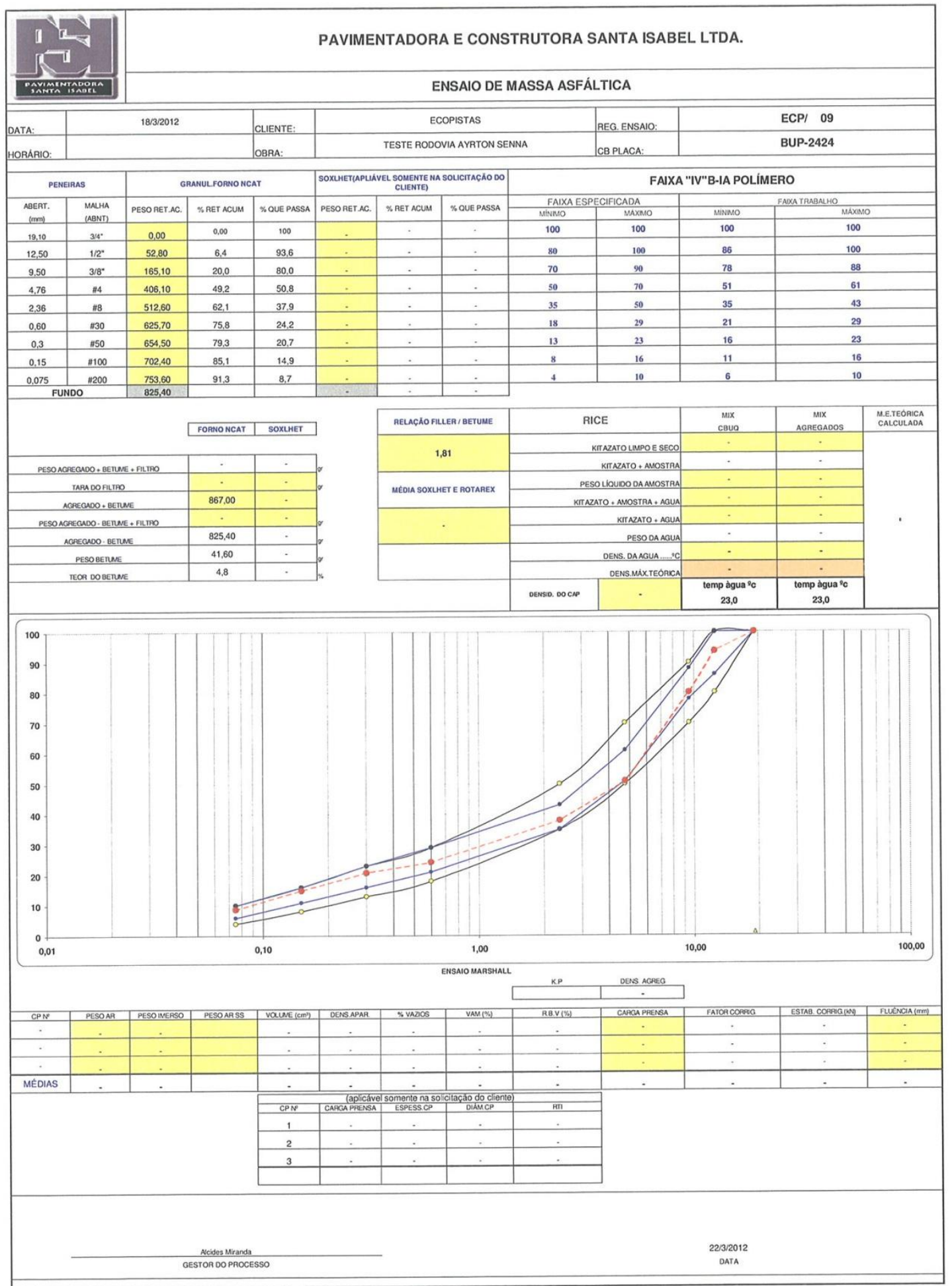




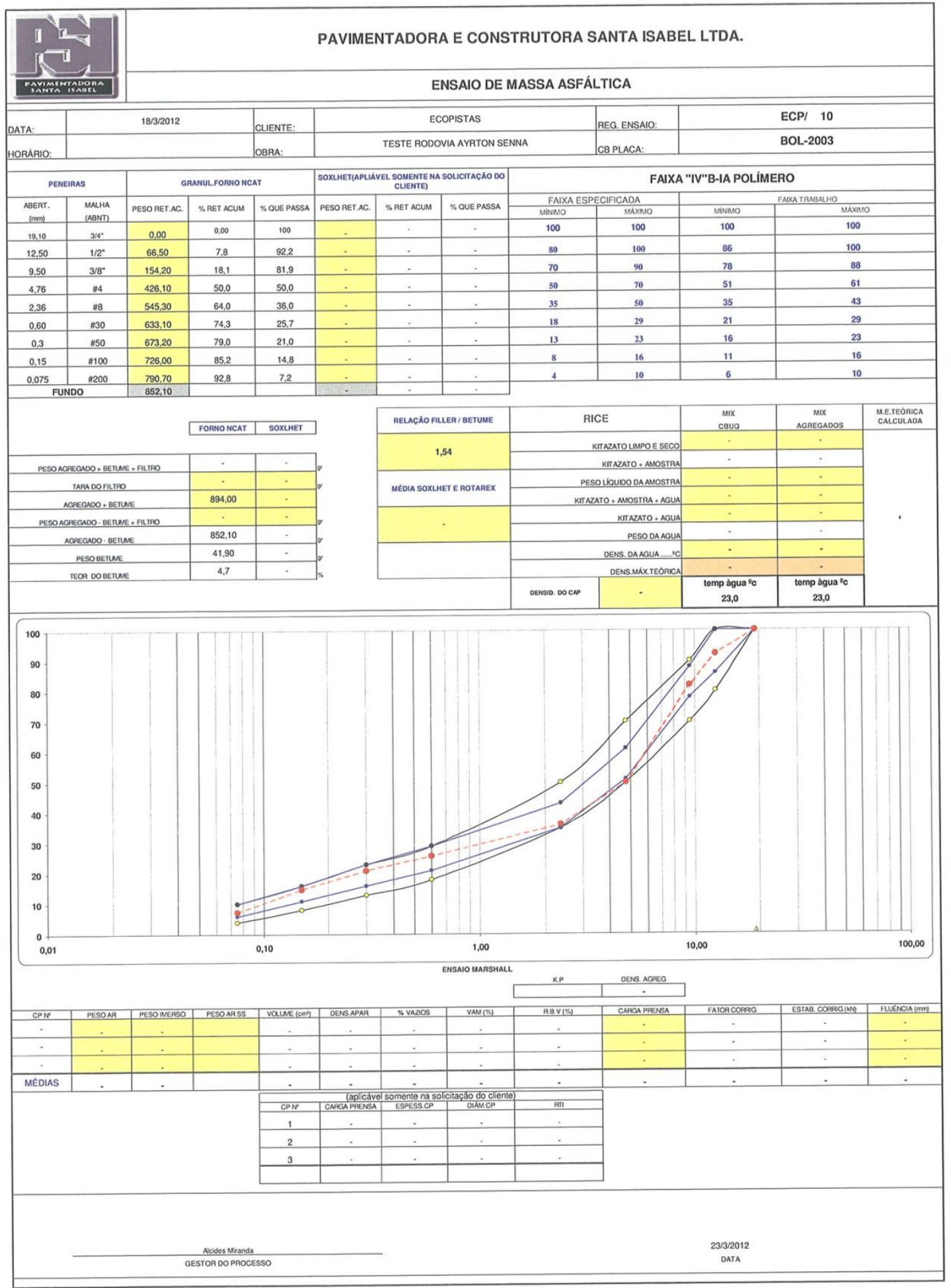




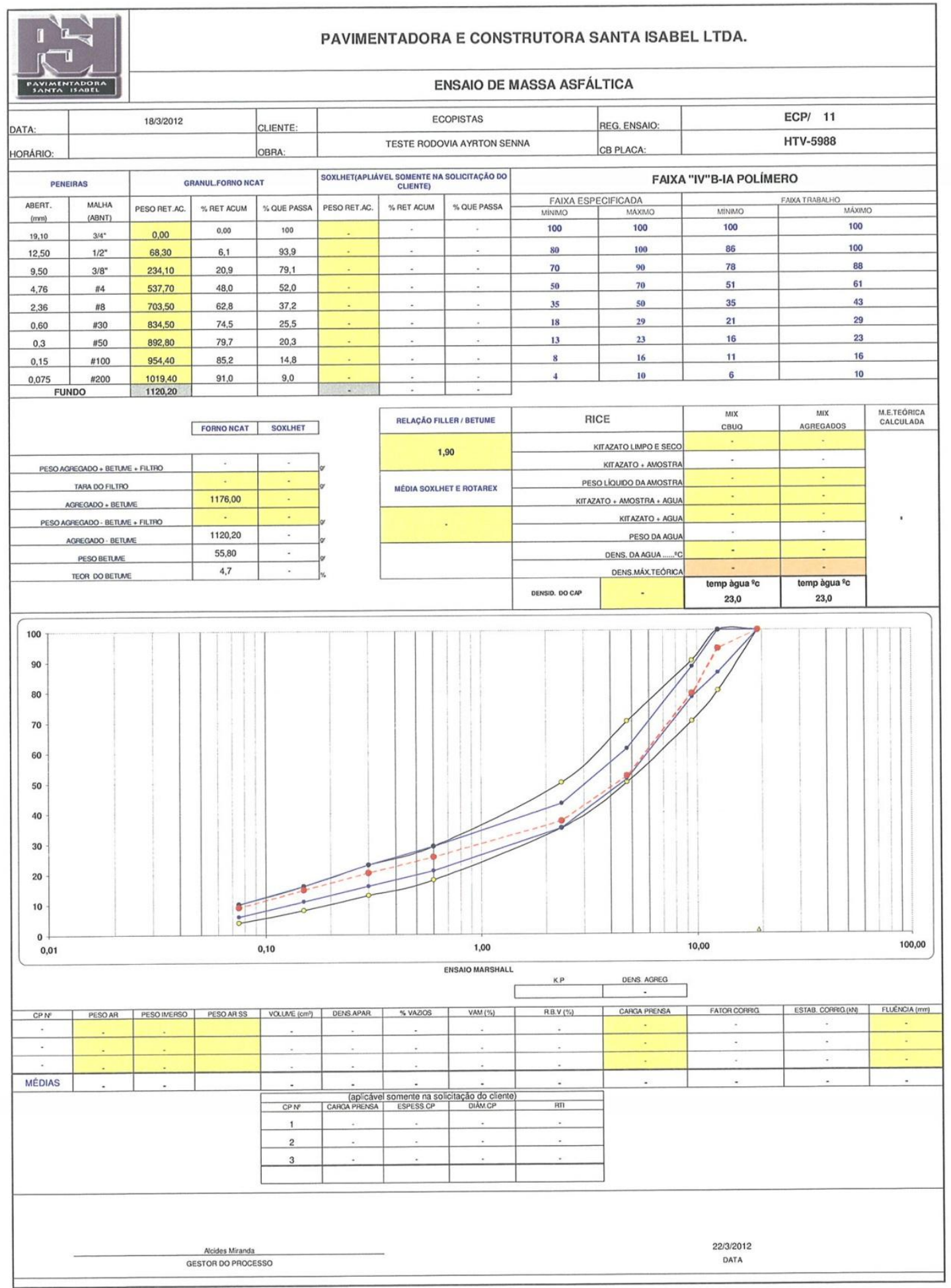




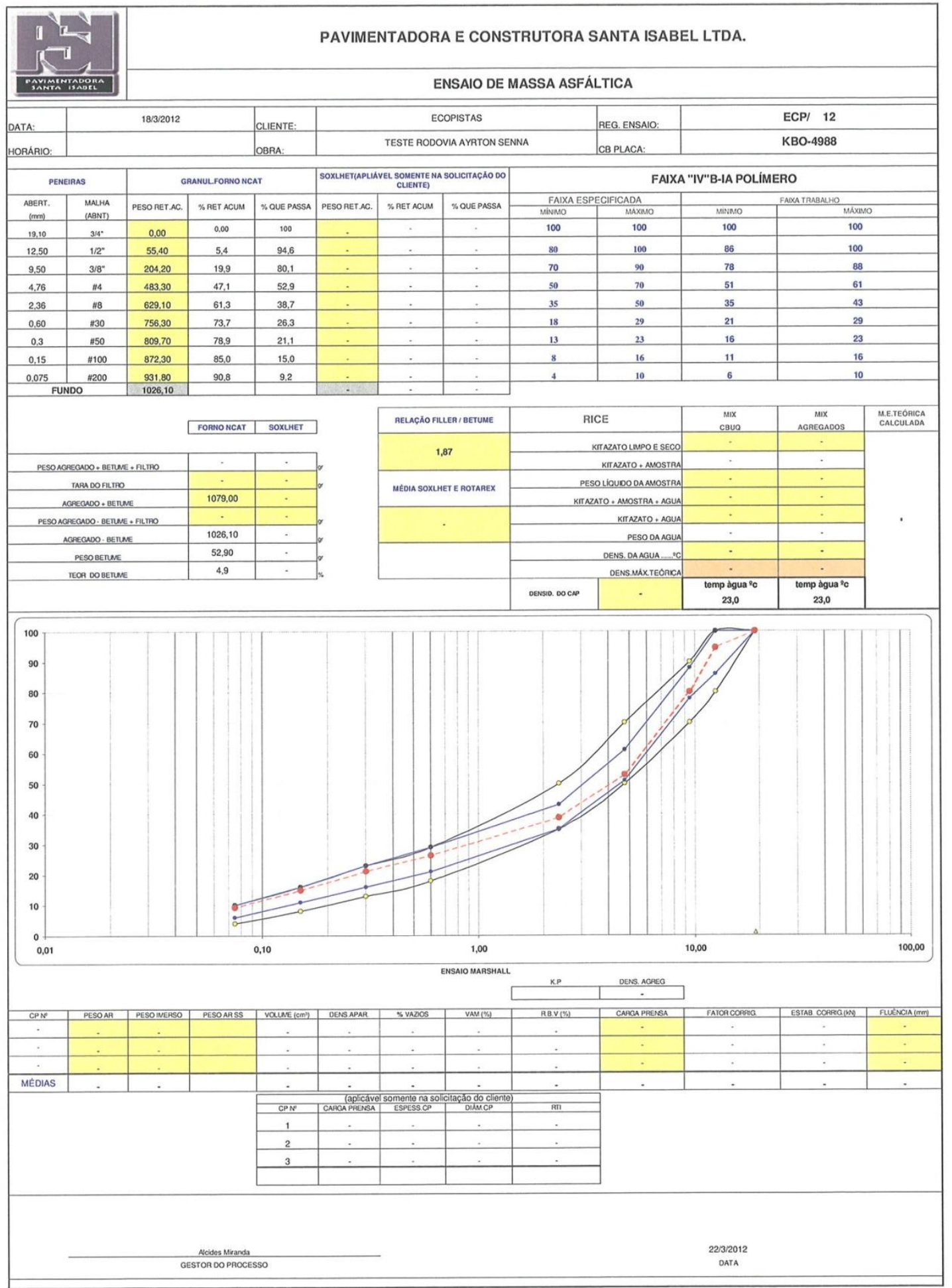




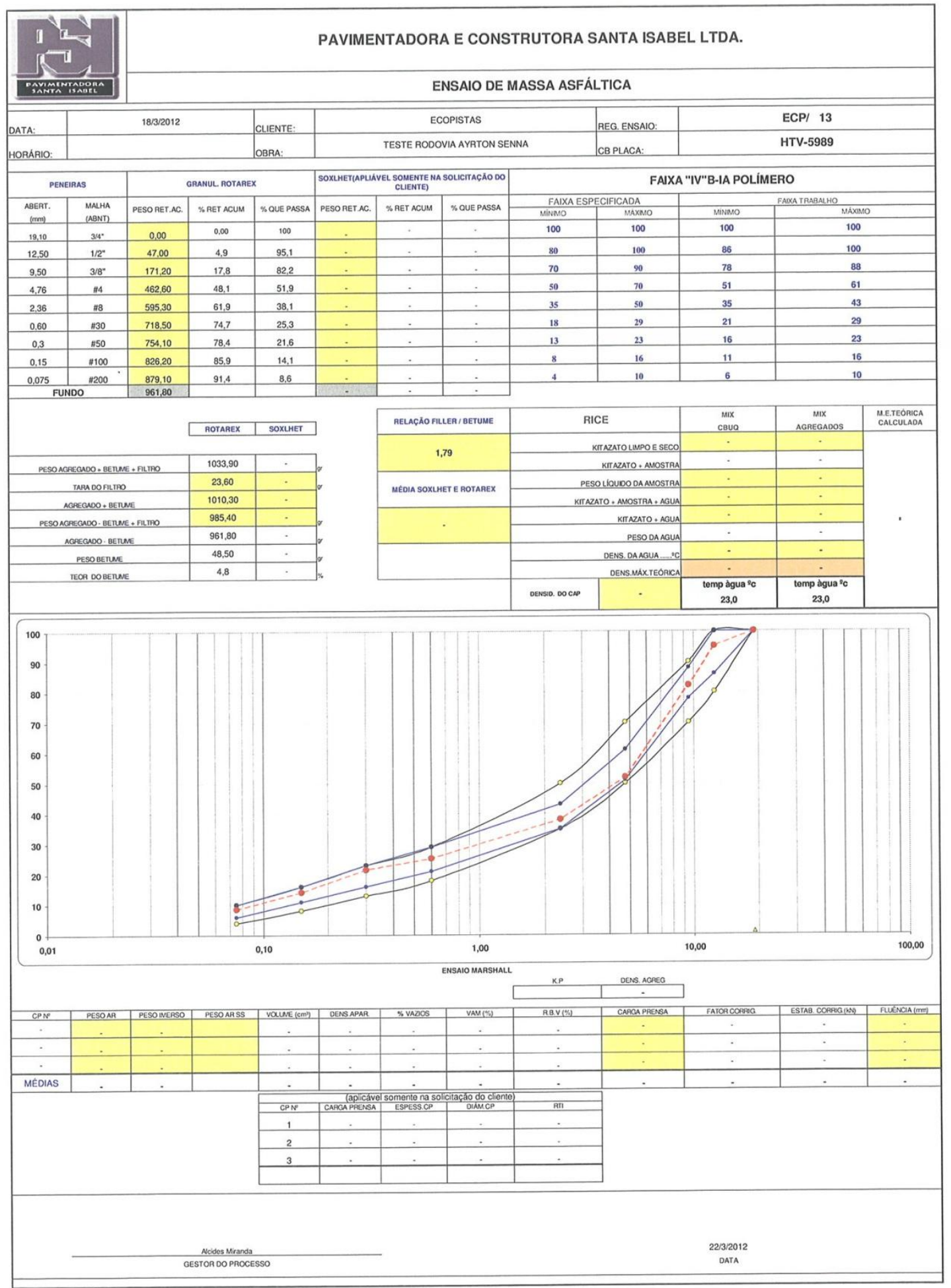




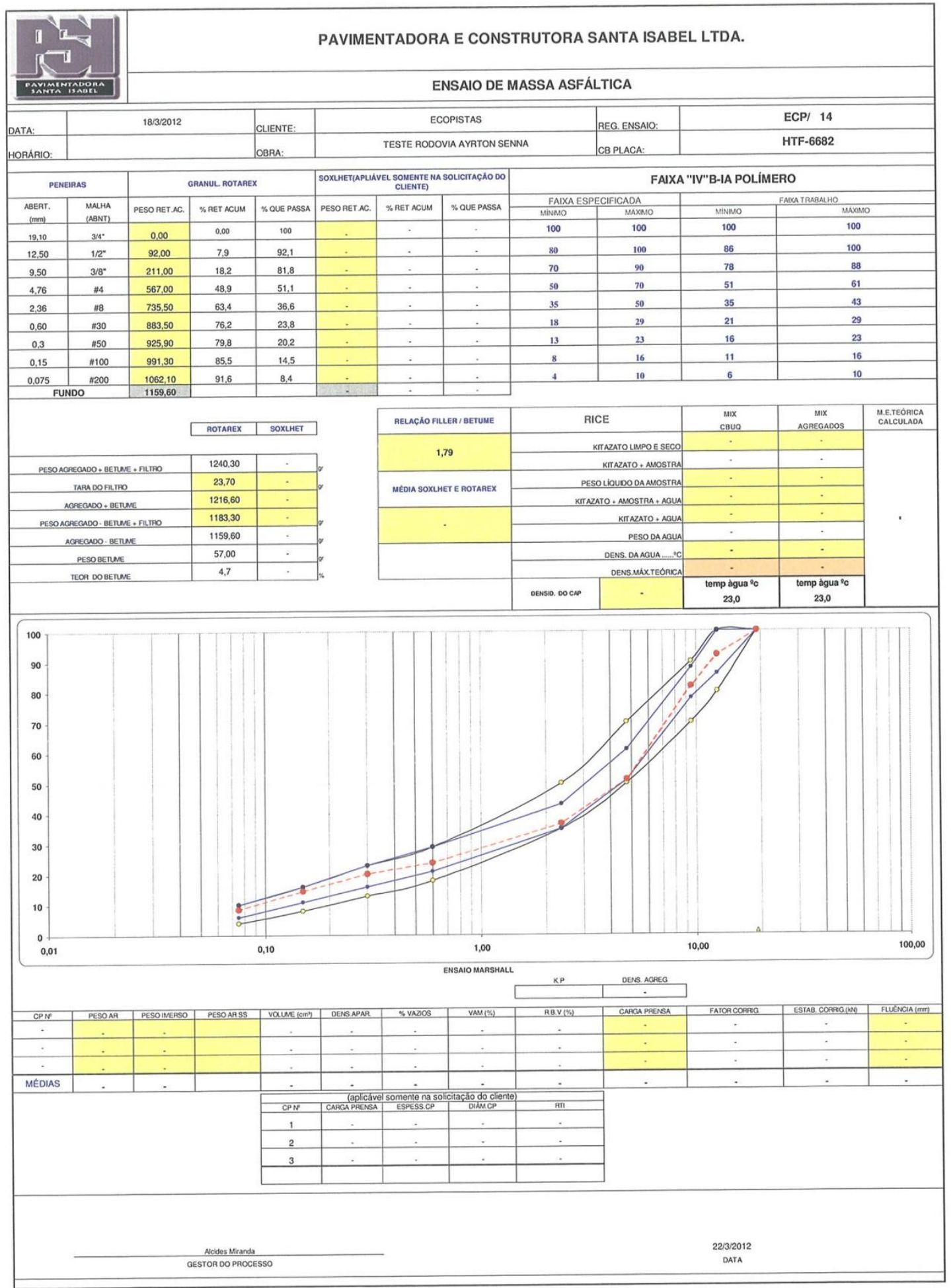




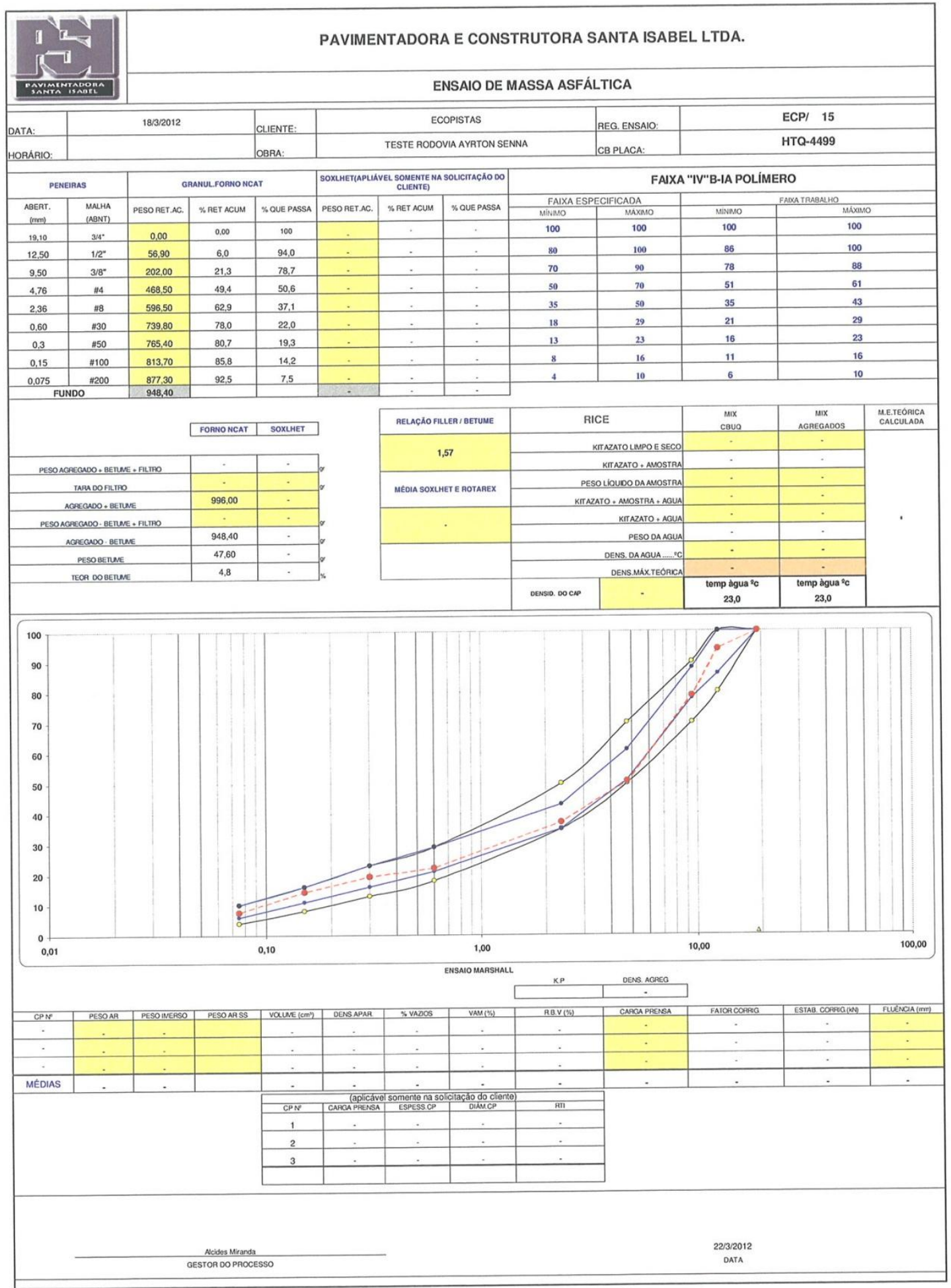




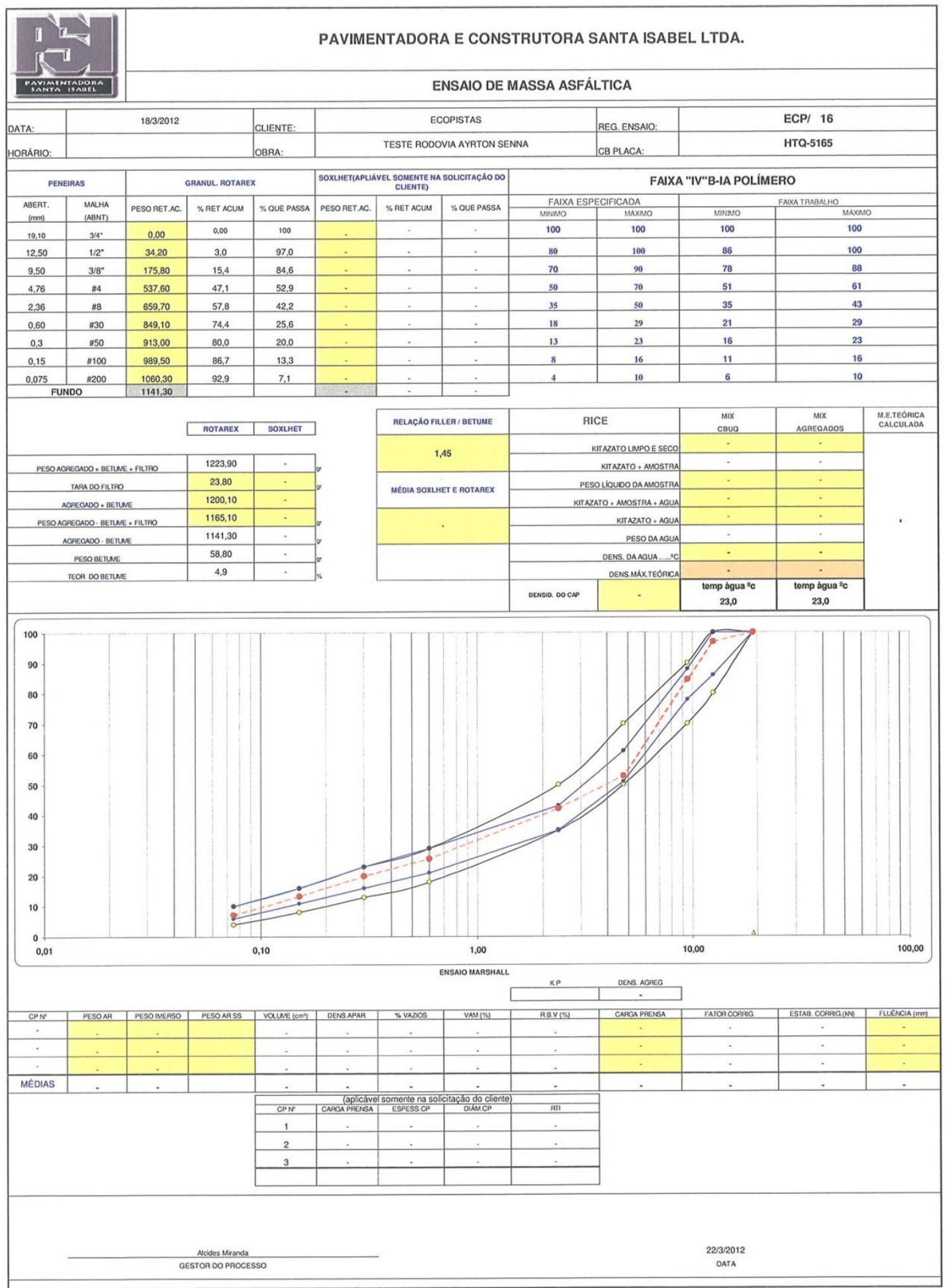




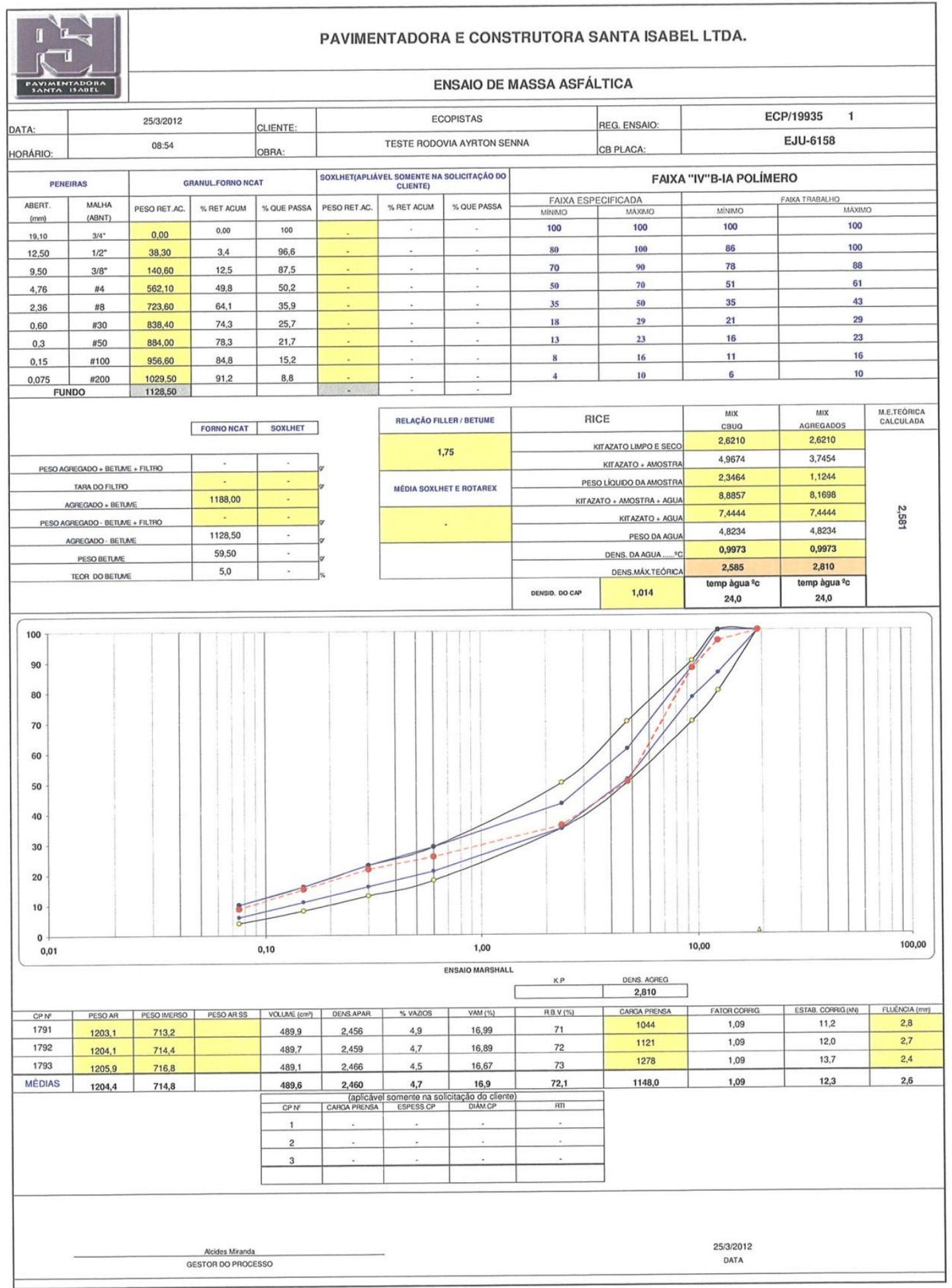




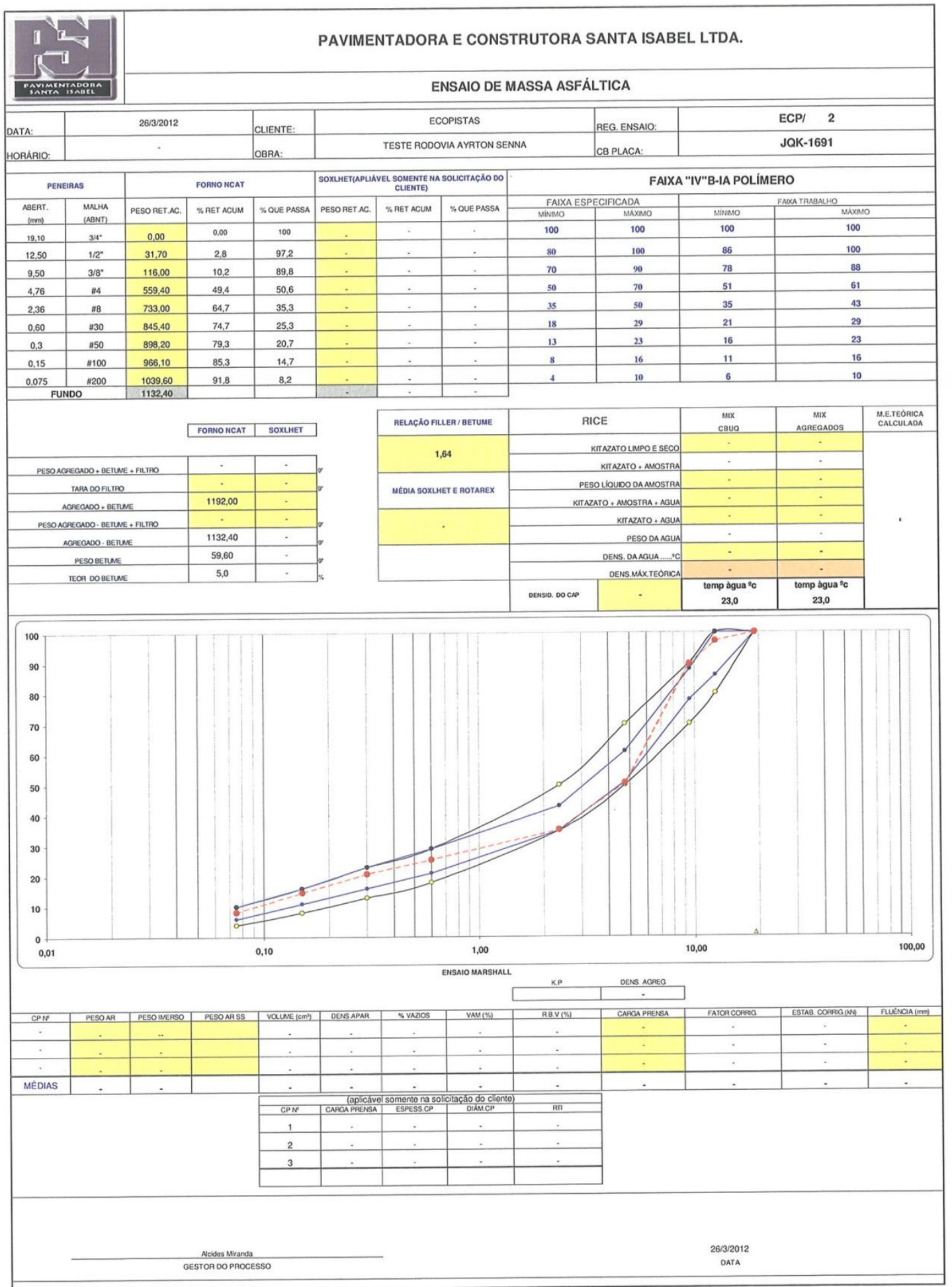




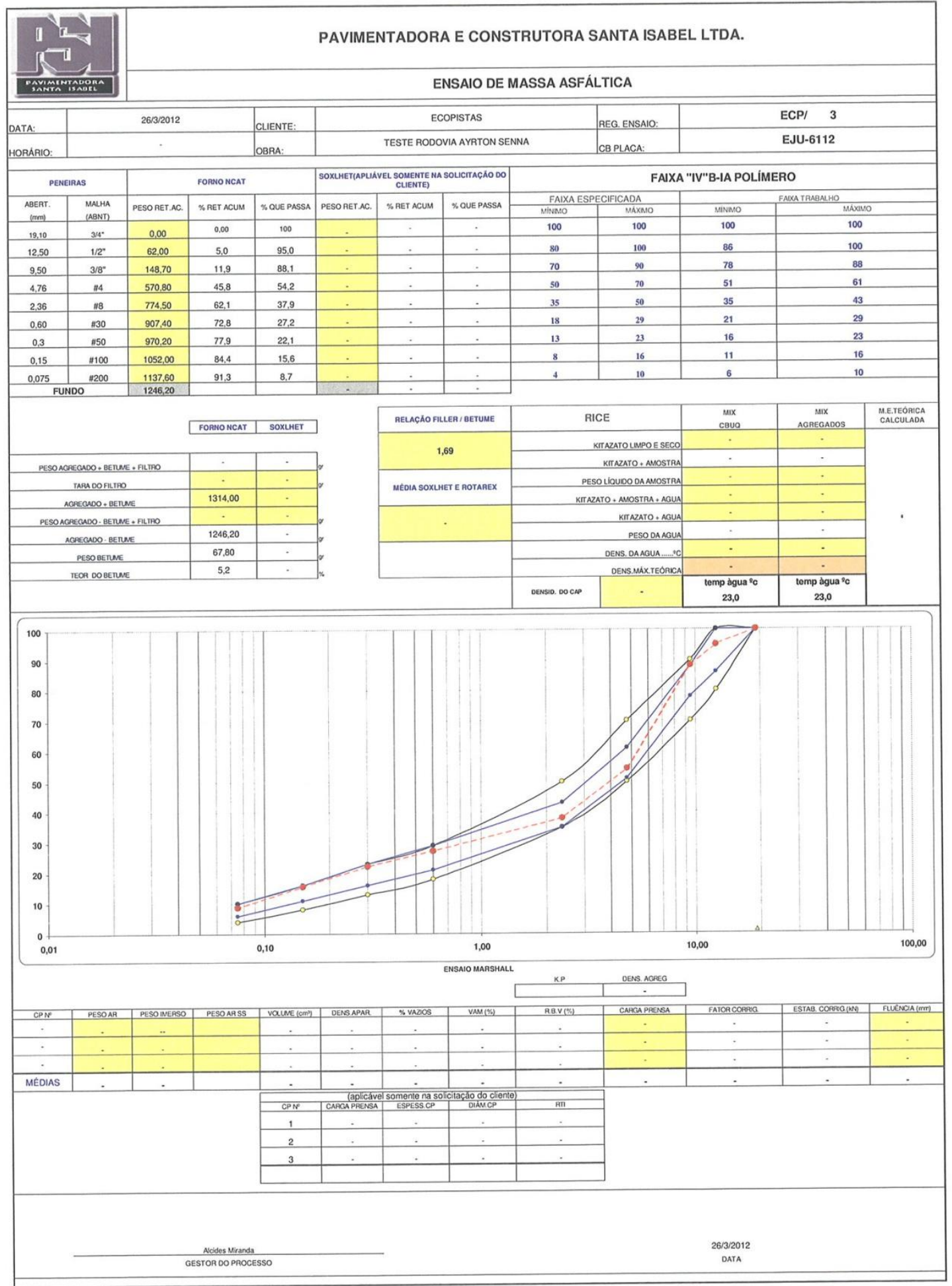




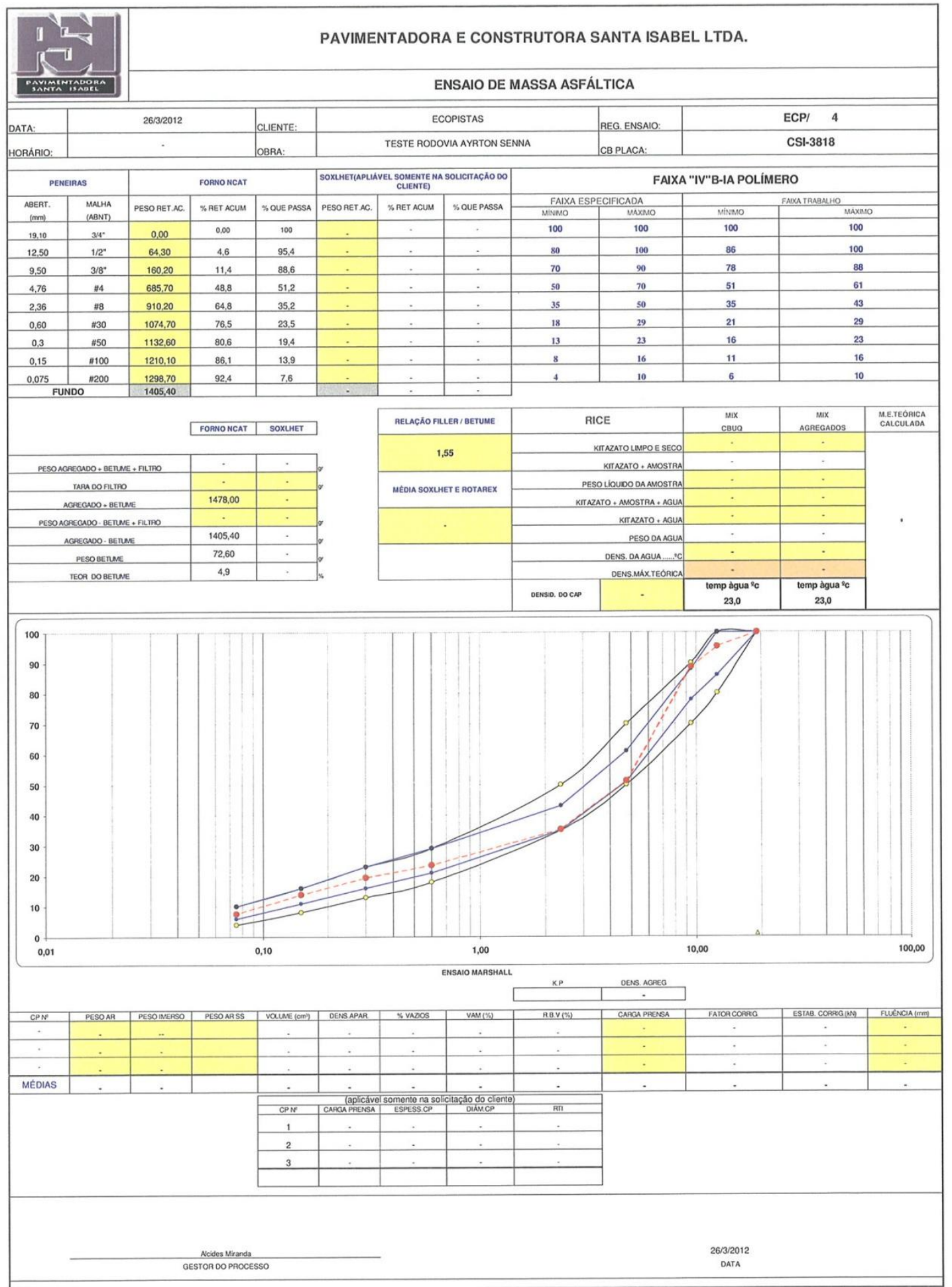




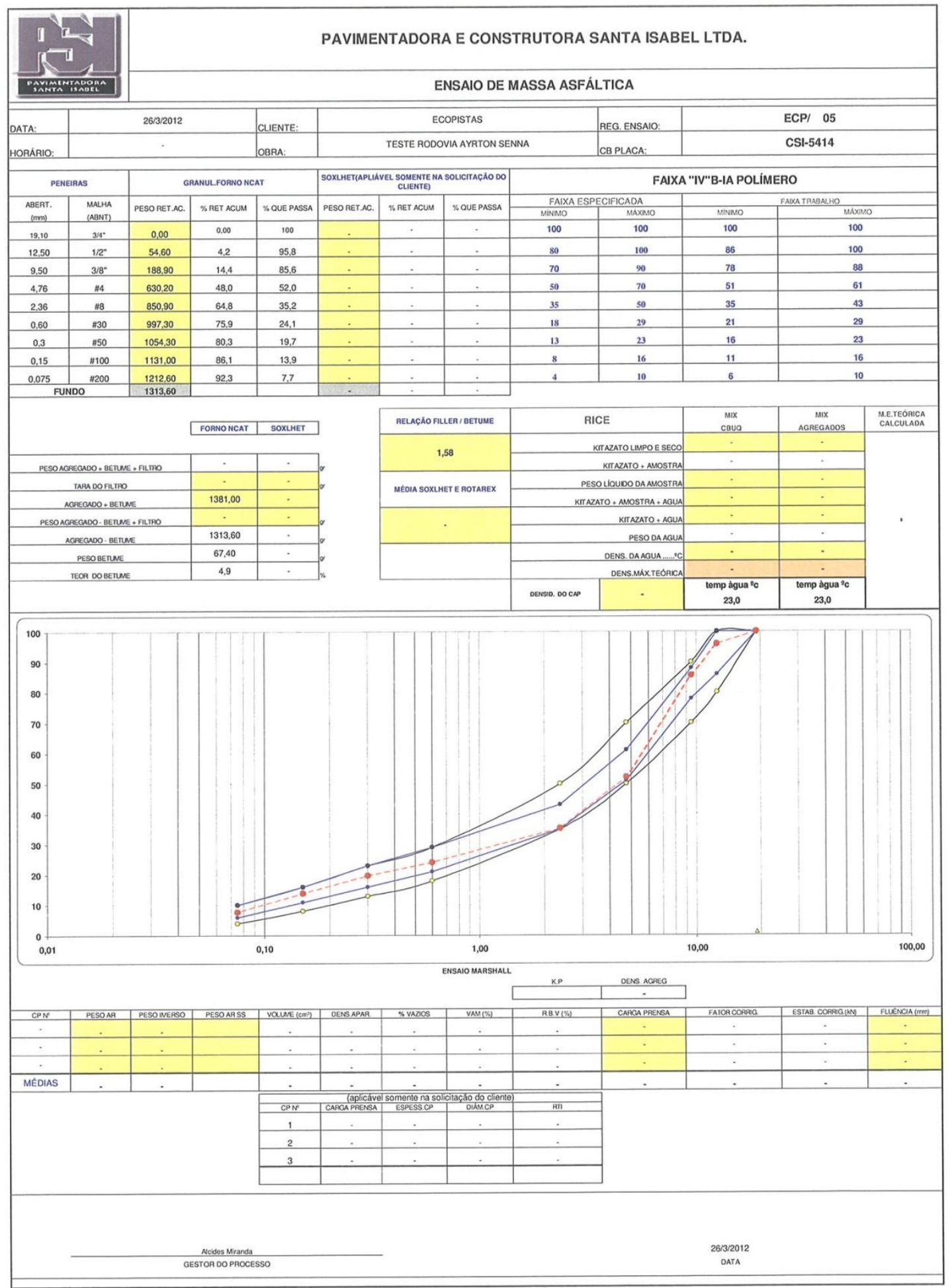




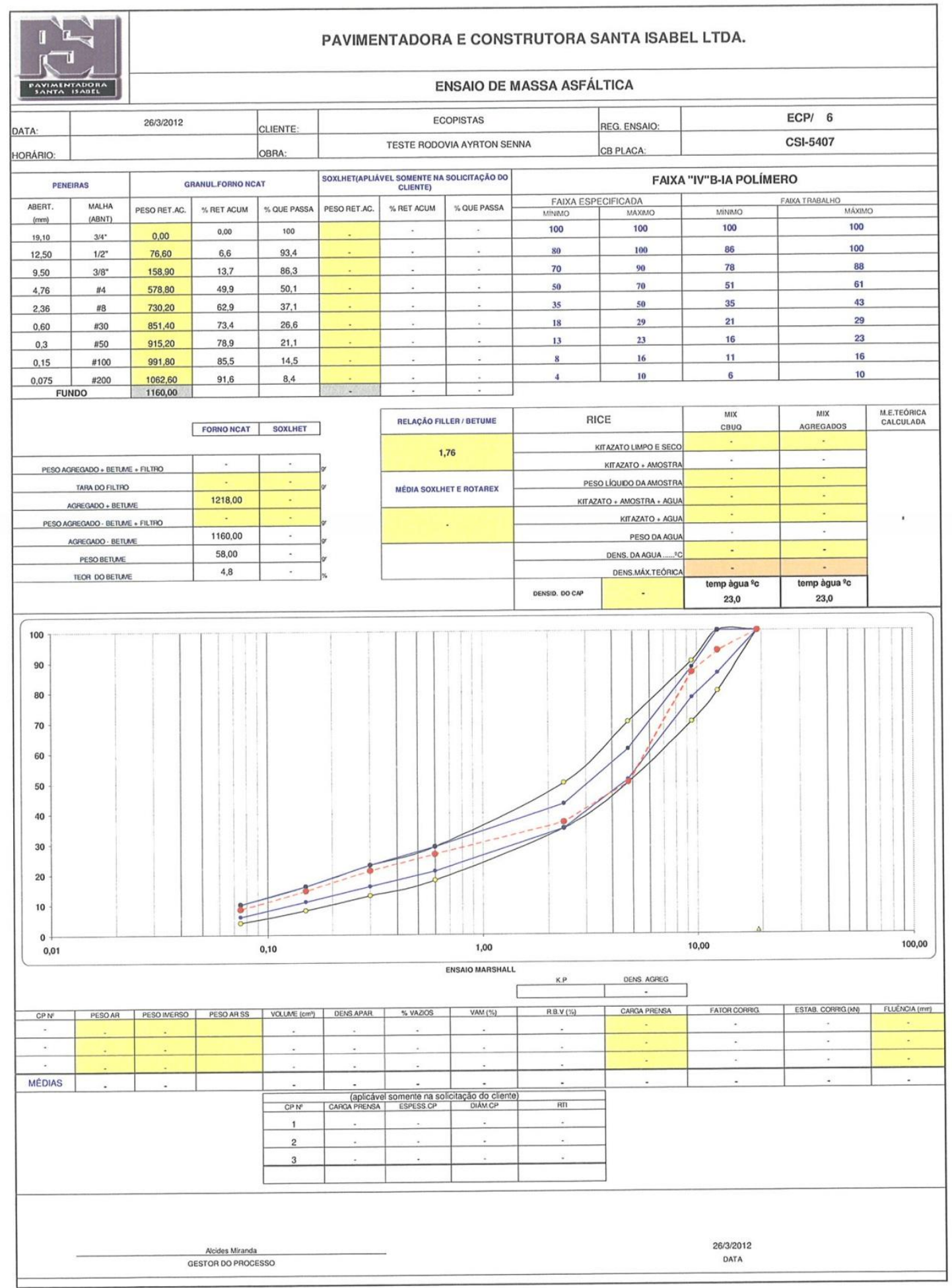




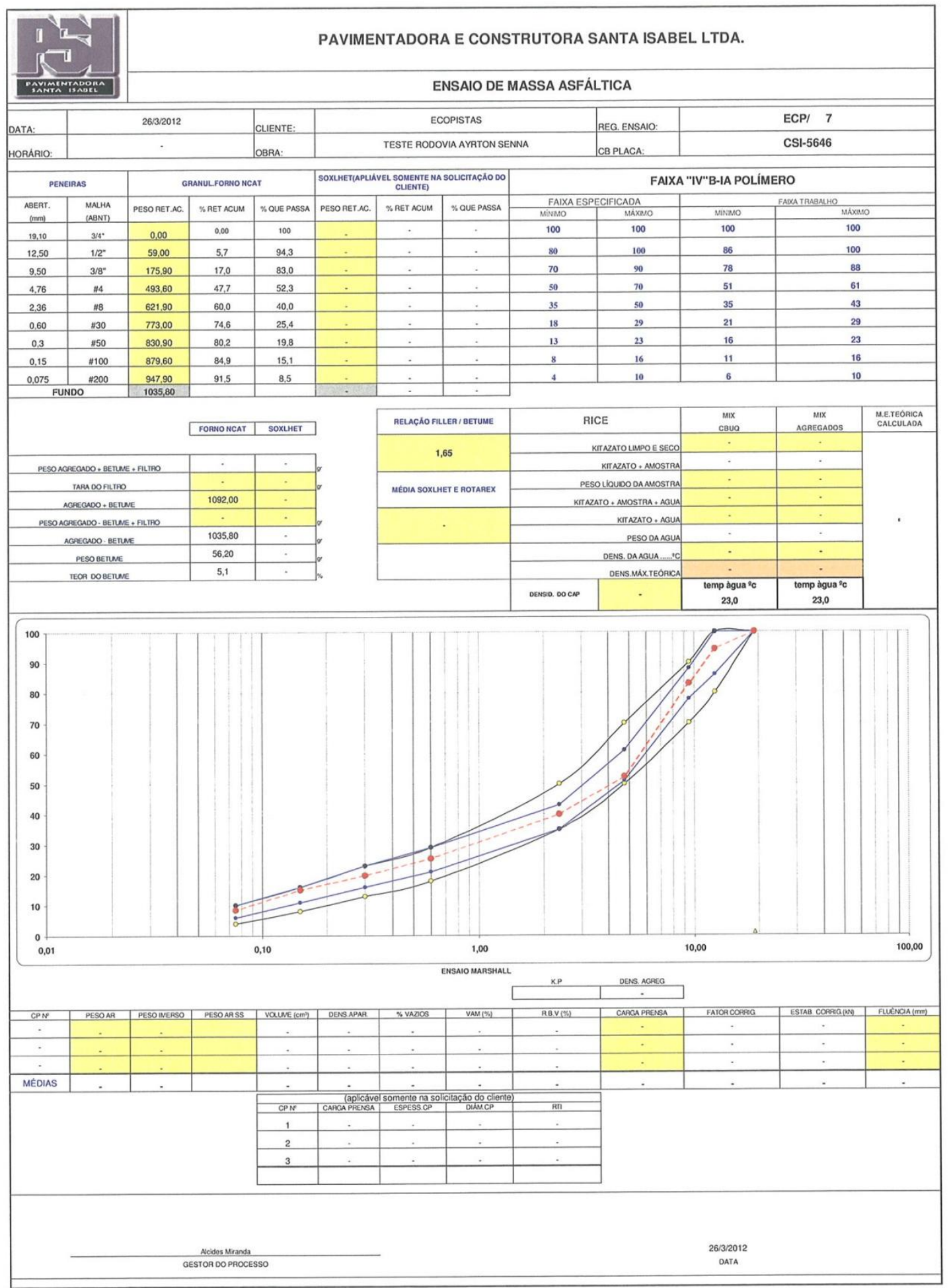




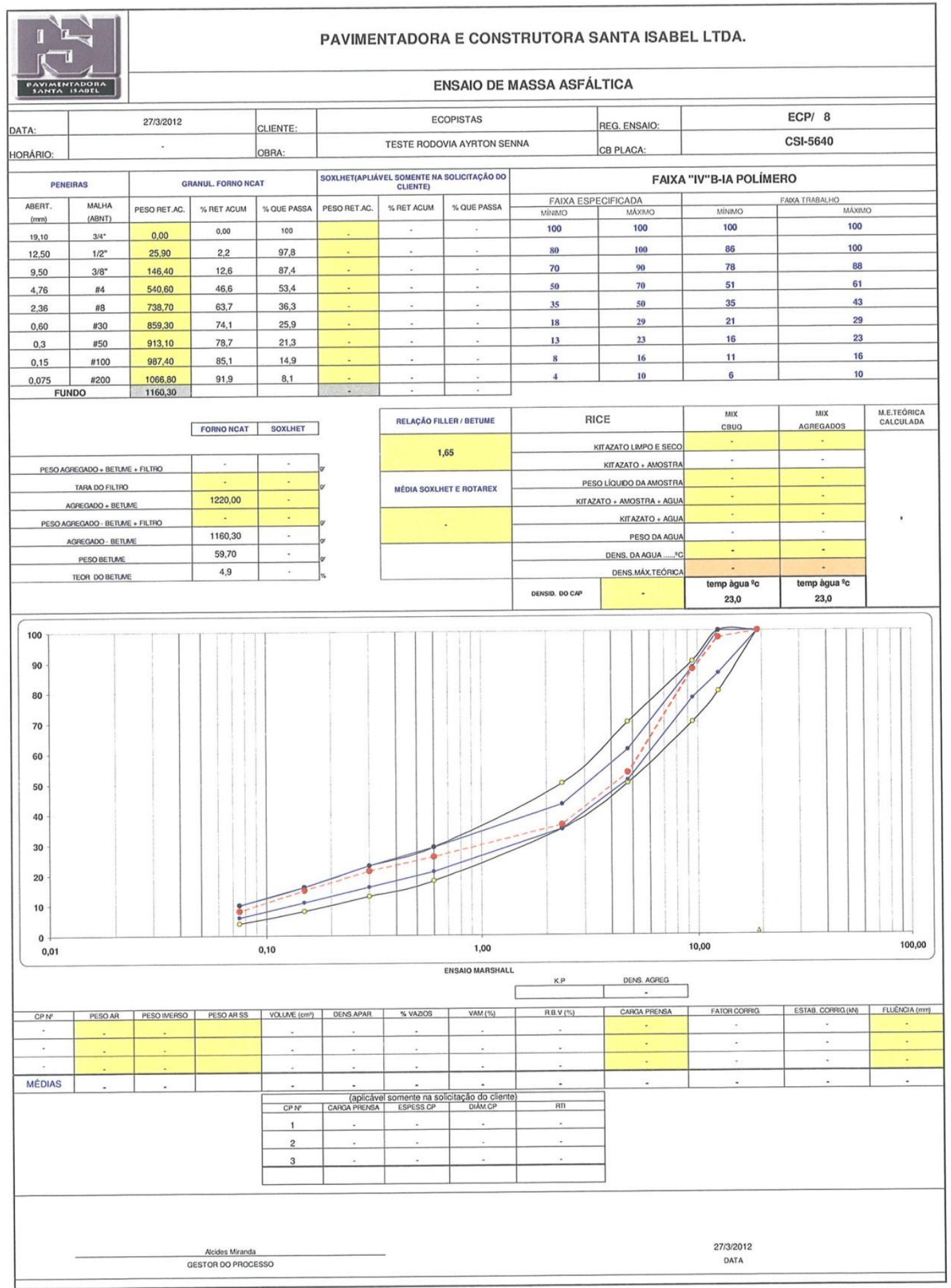




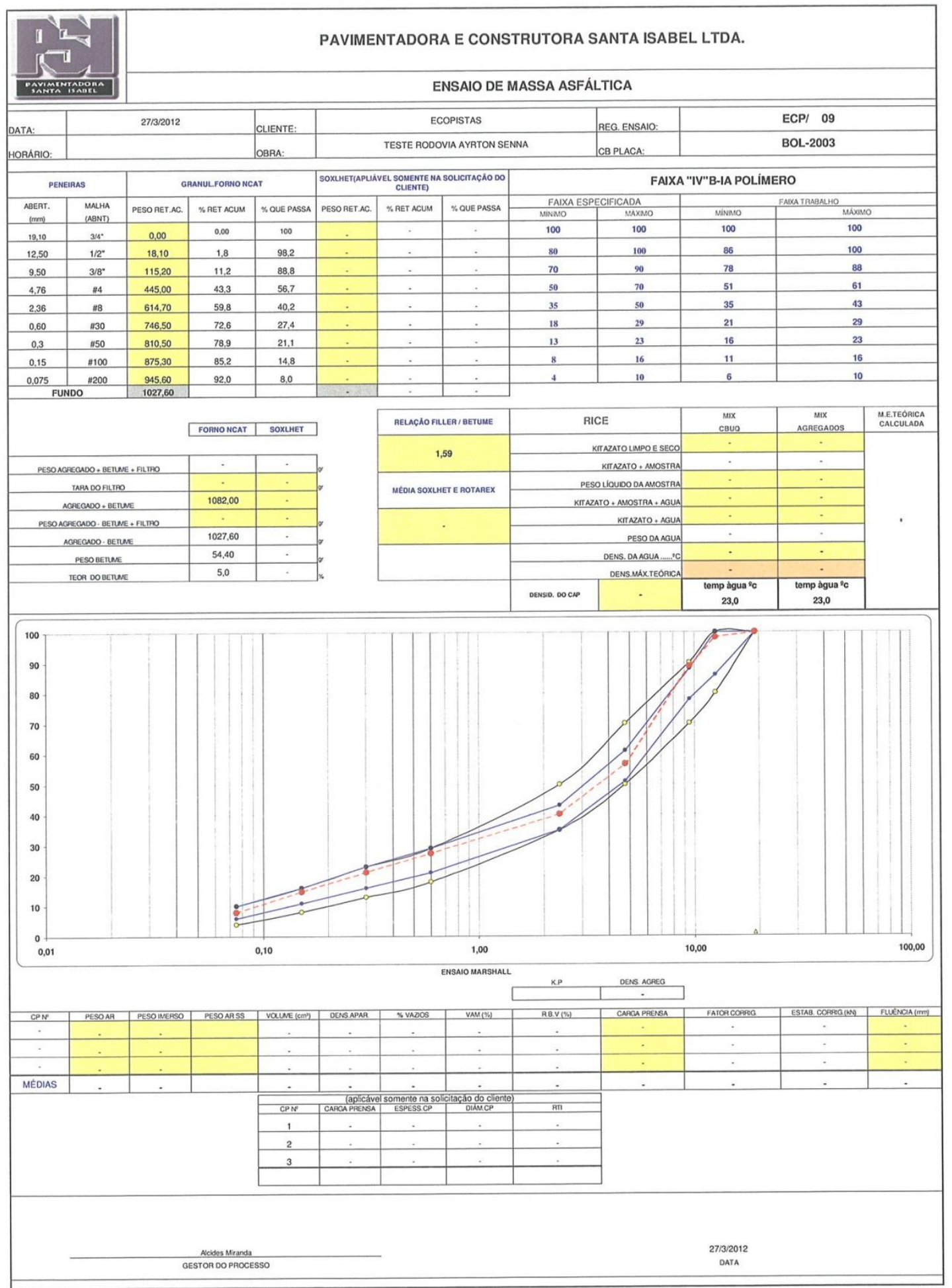




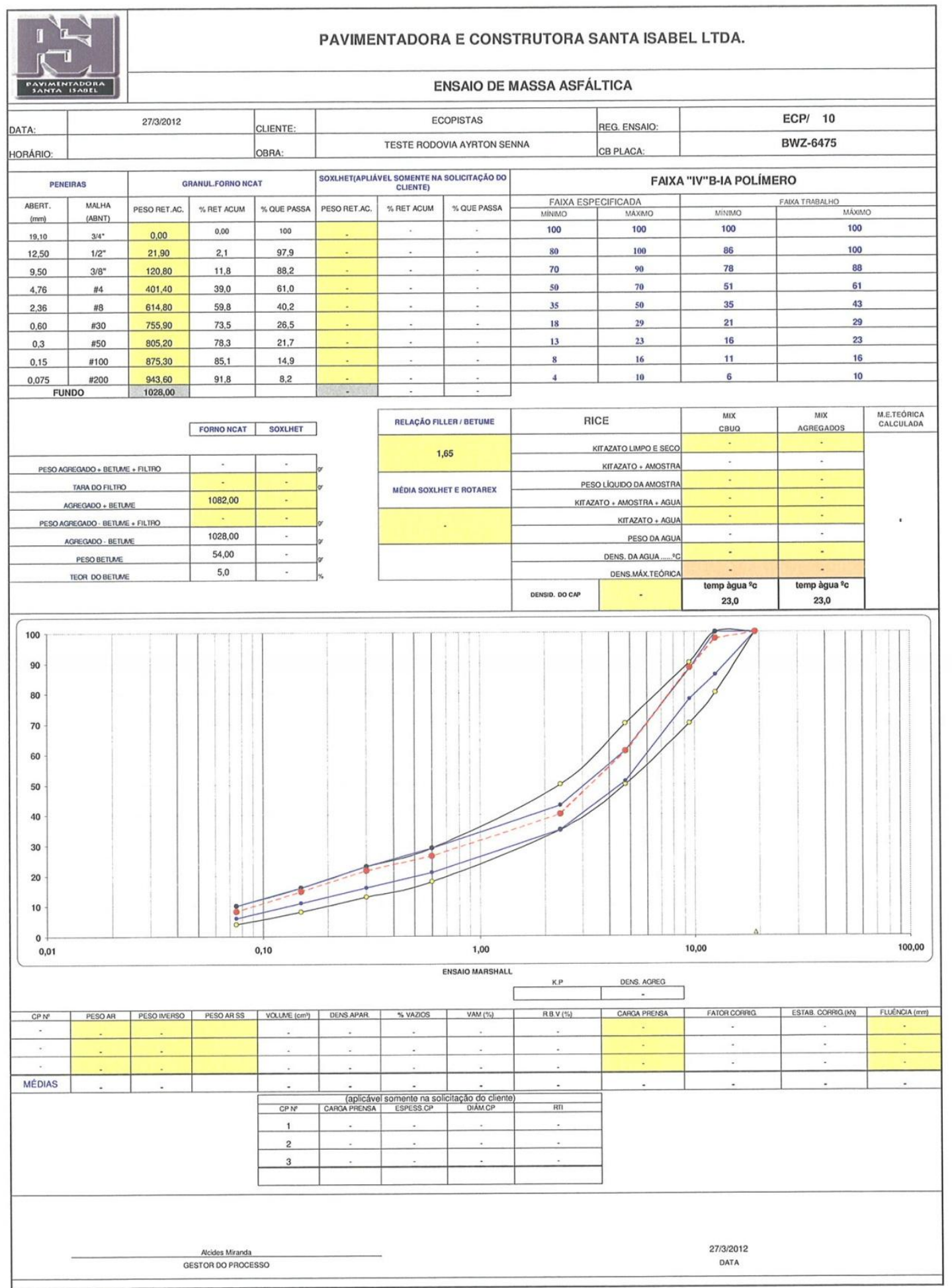




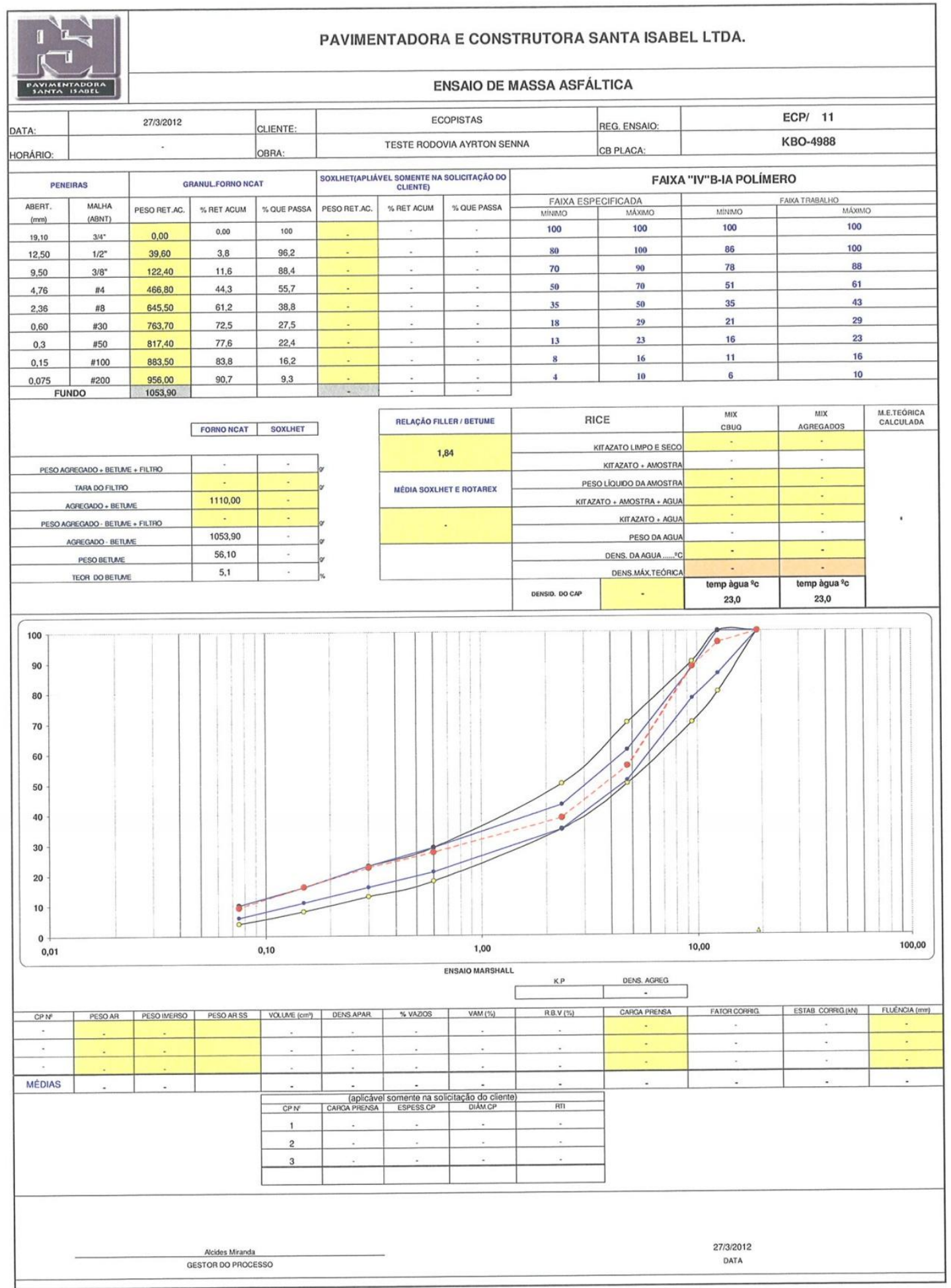




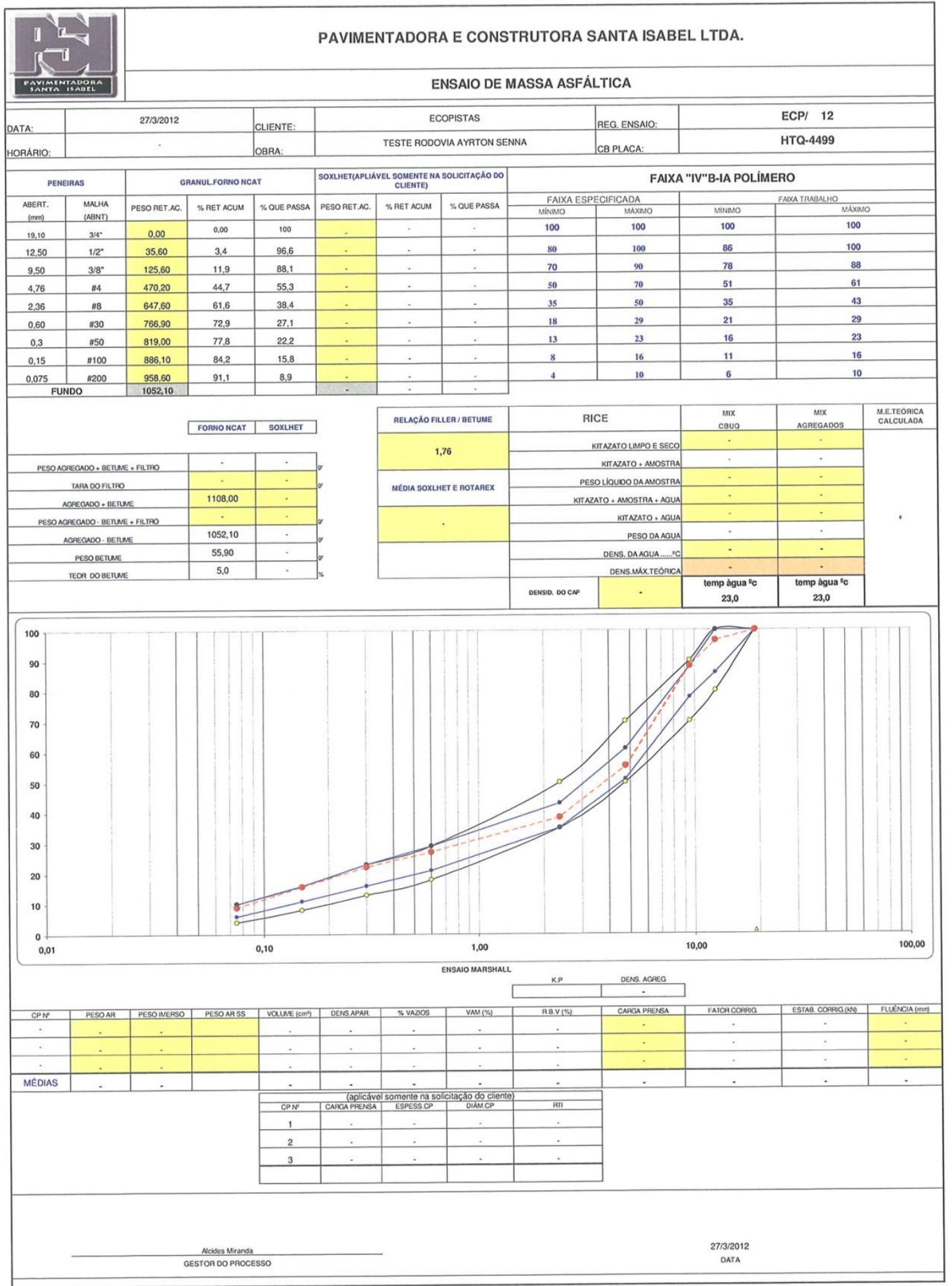




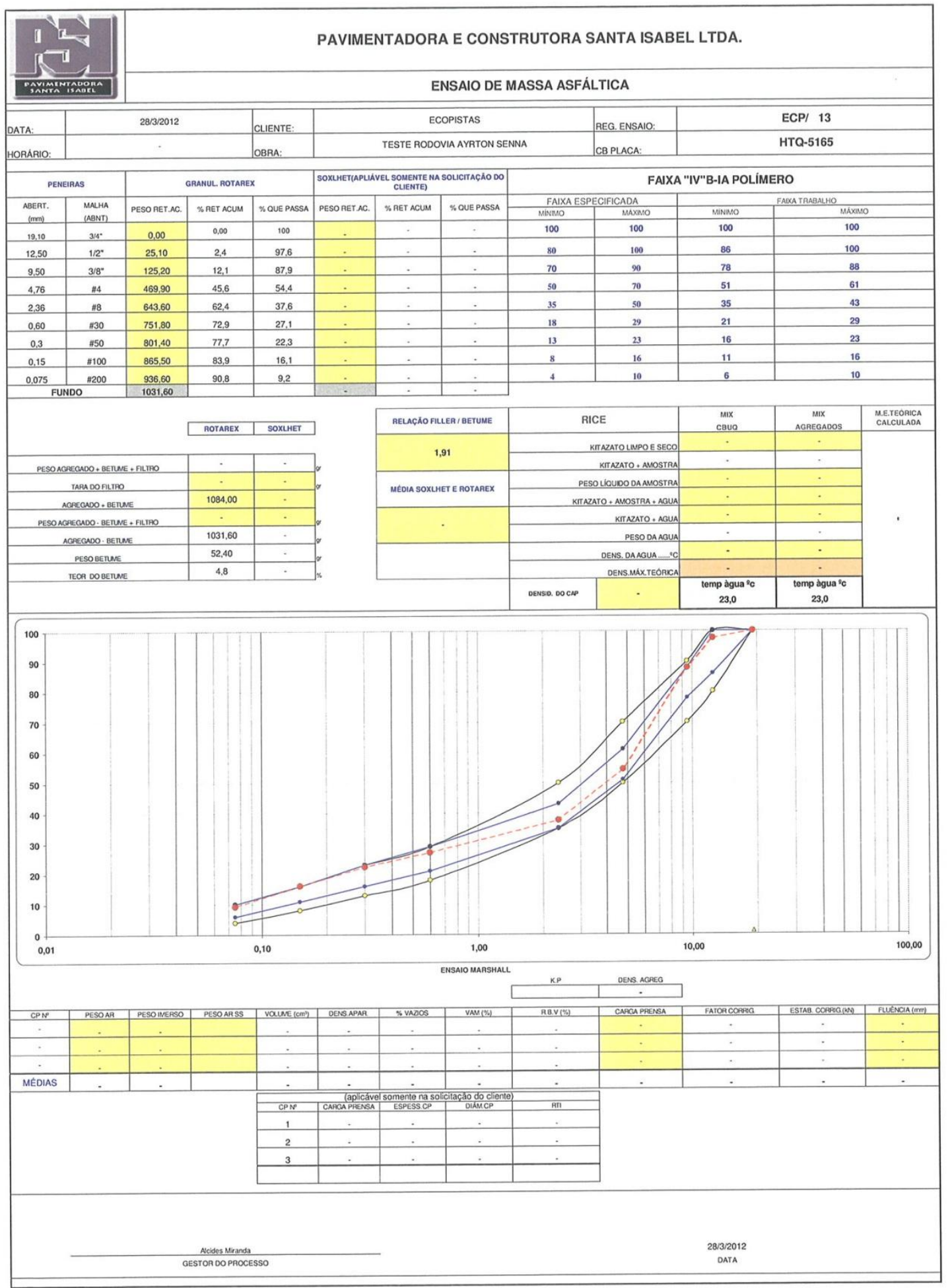




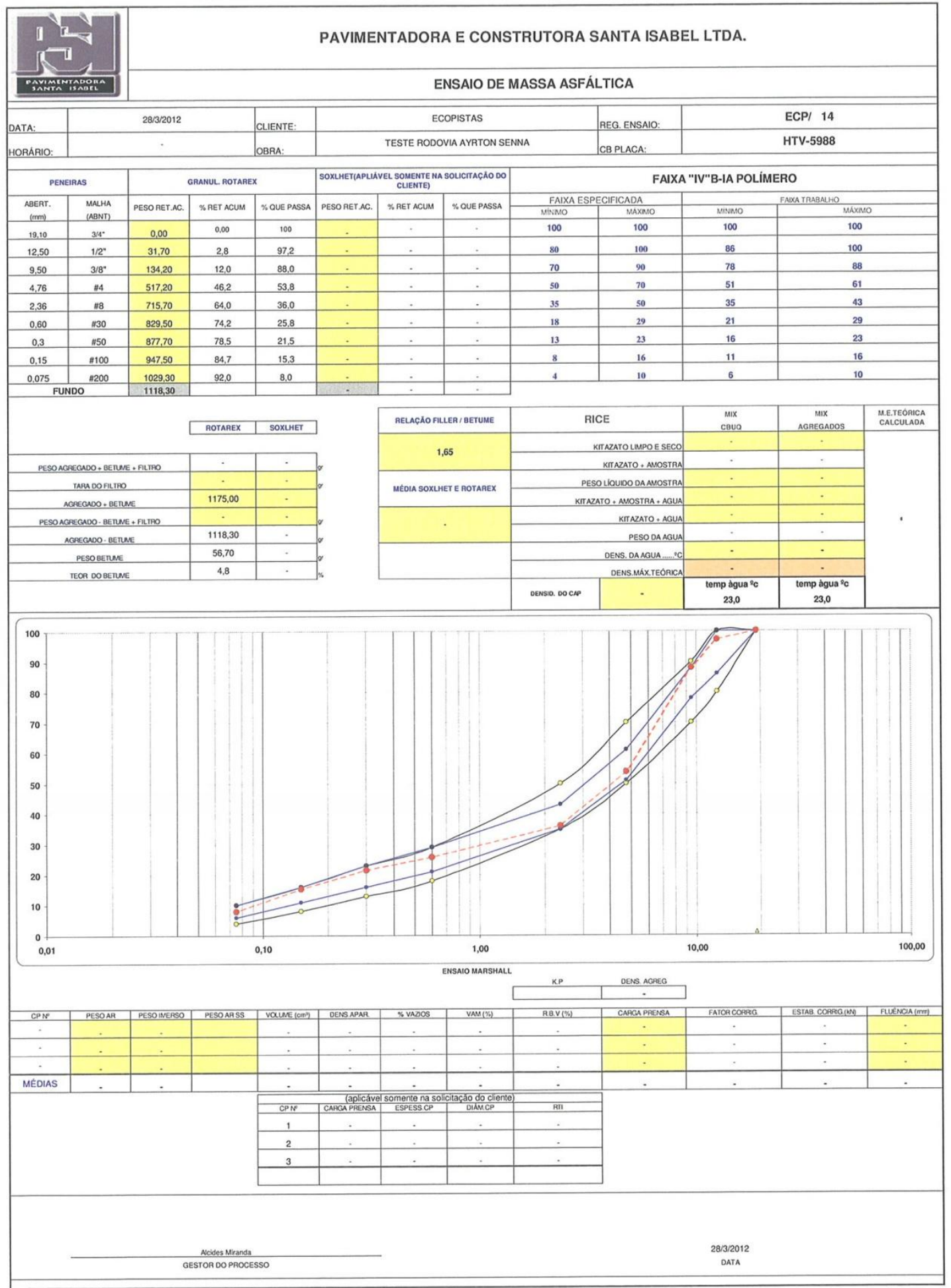




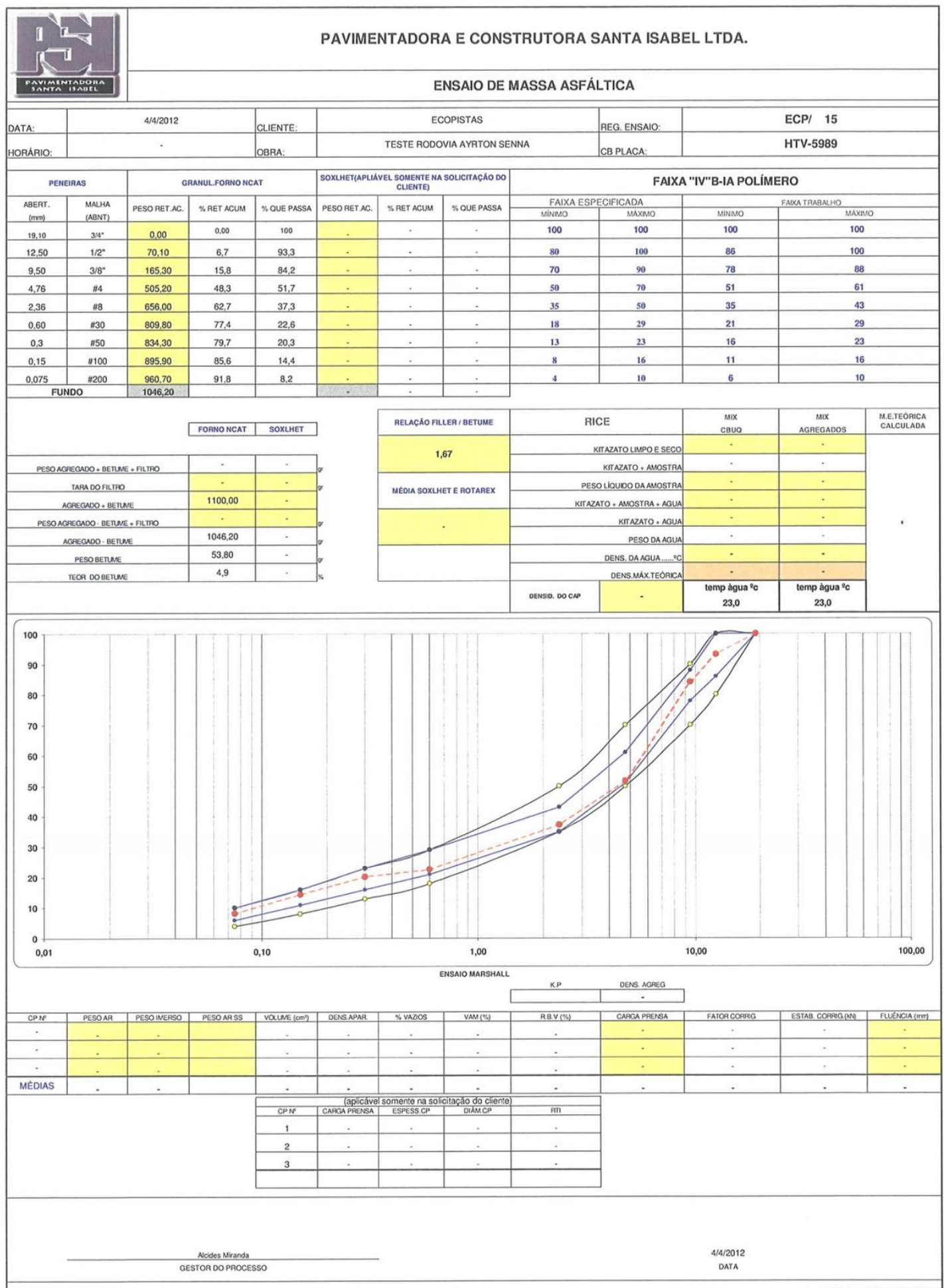




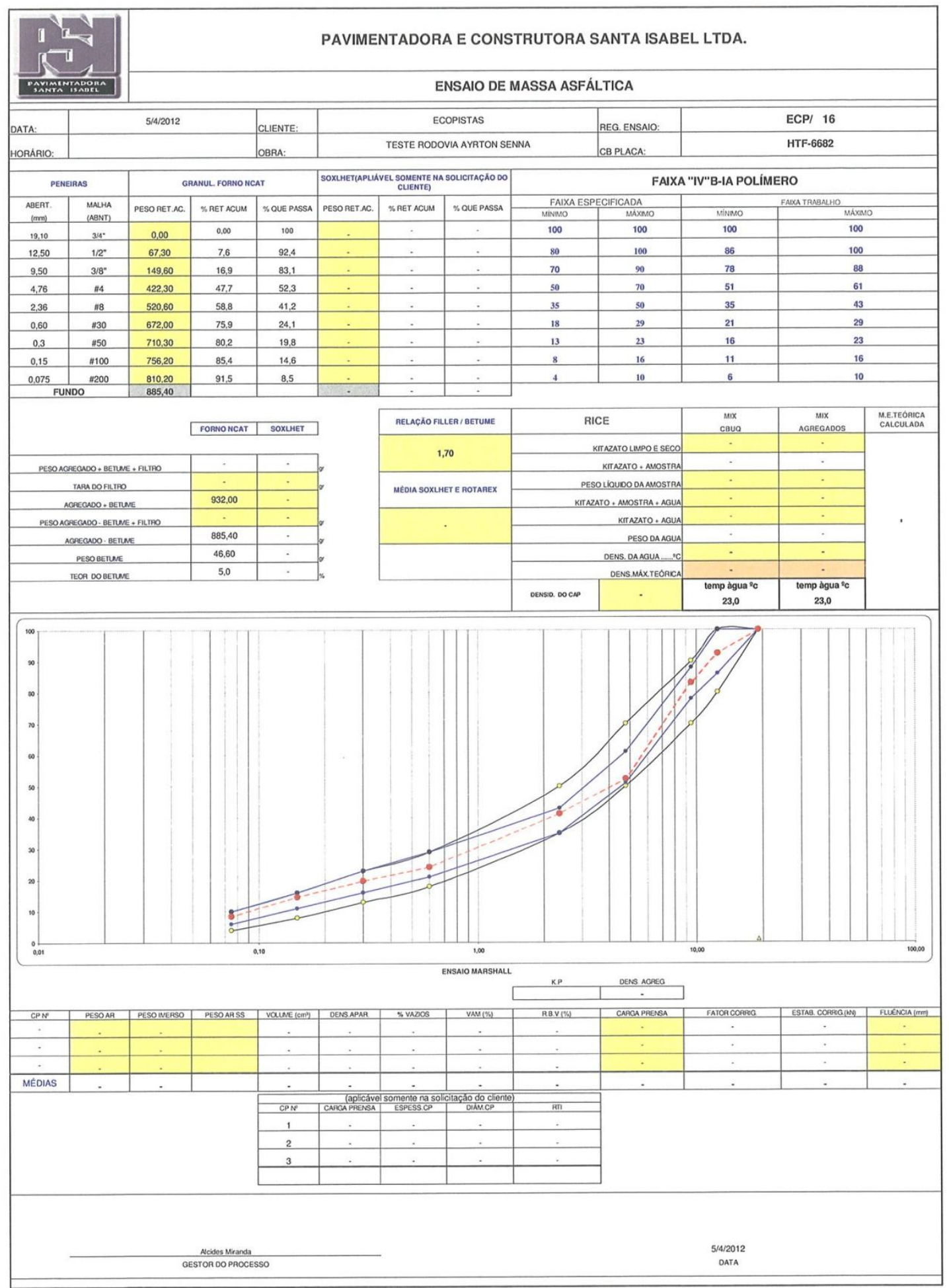




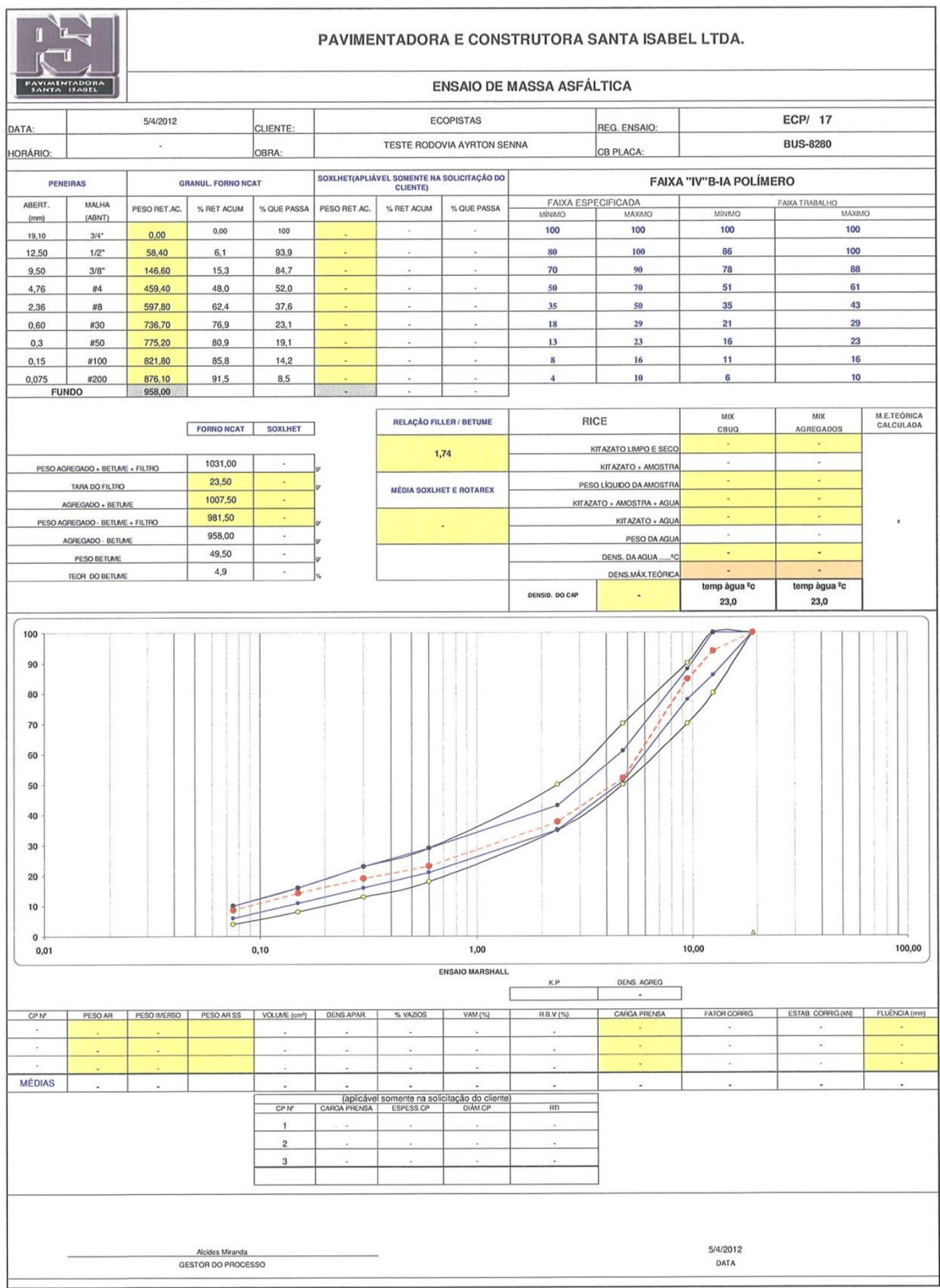


H. Ligante utilizado nas misturas de SAMI

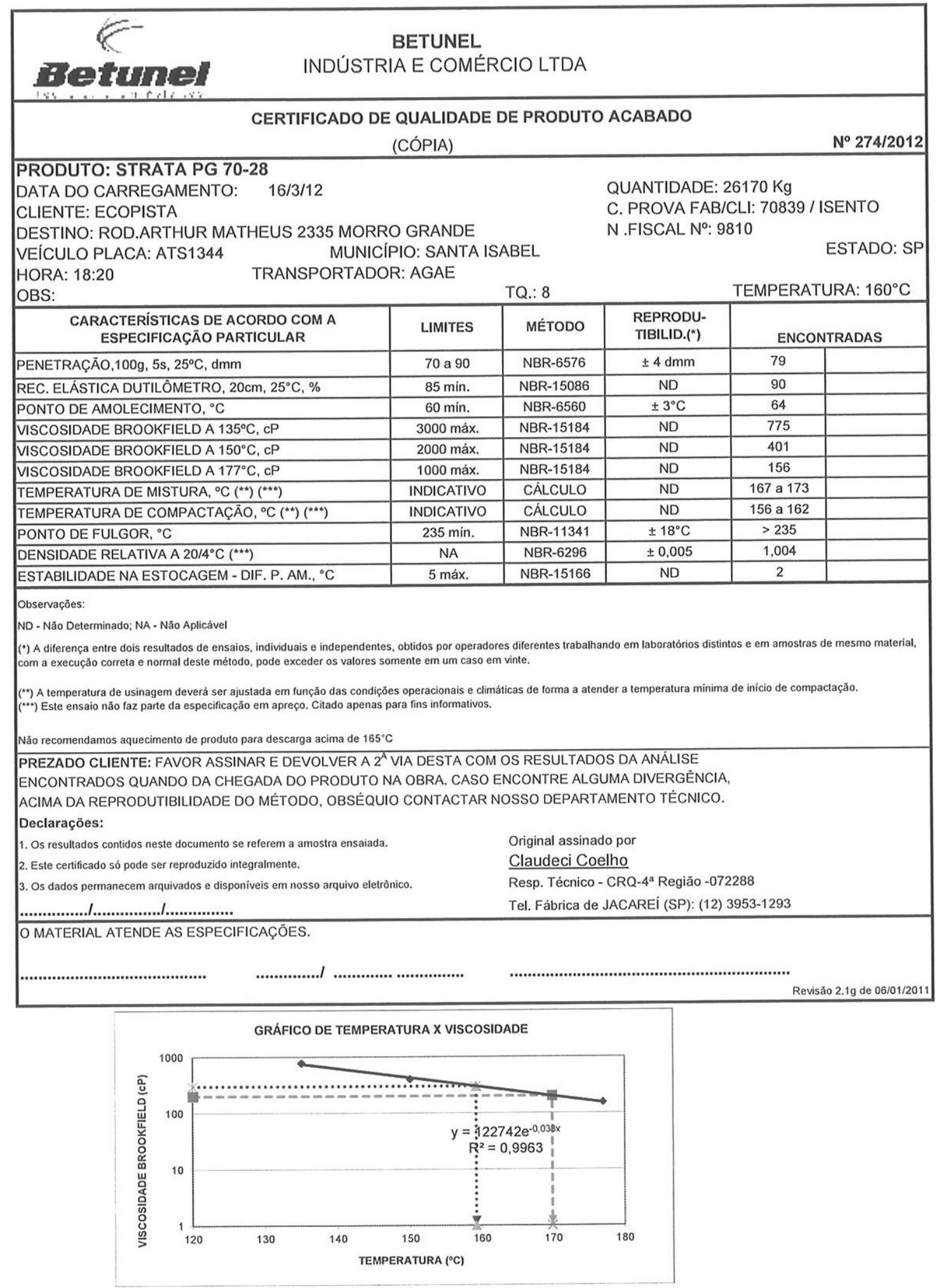




\section{Caracterização das misturas de SAMI}

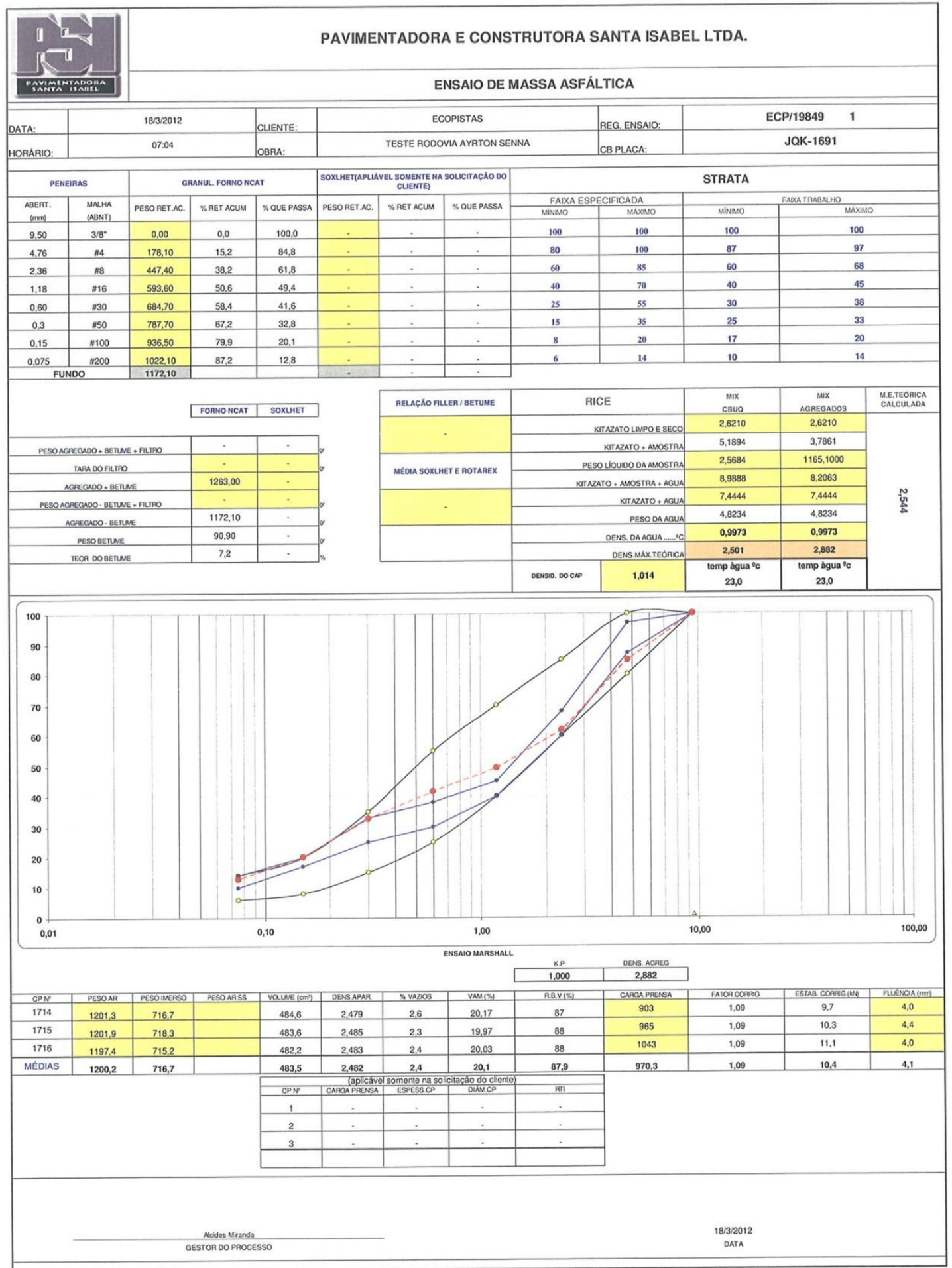




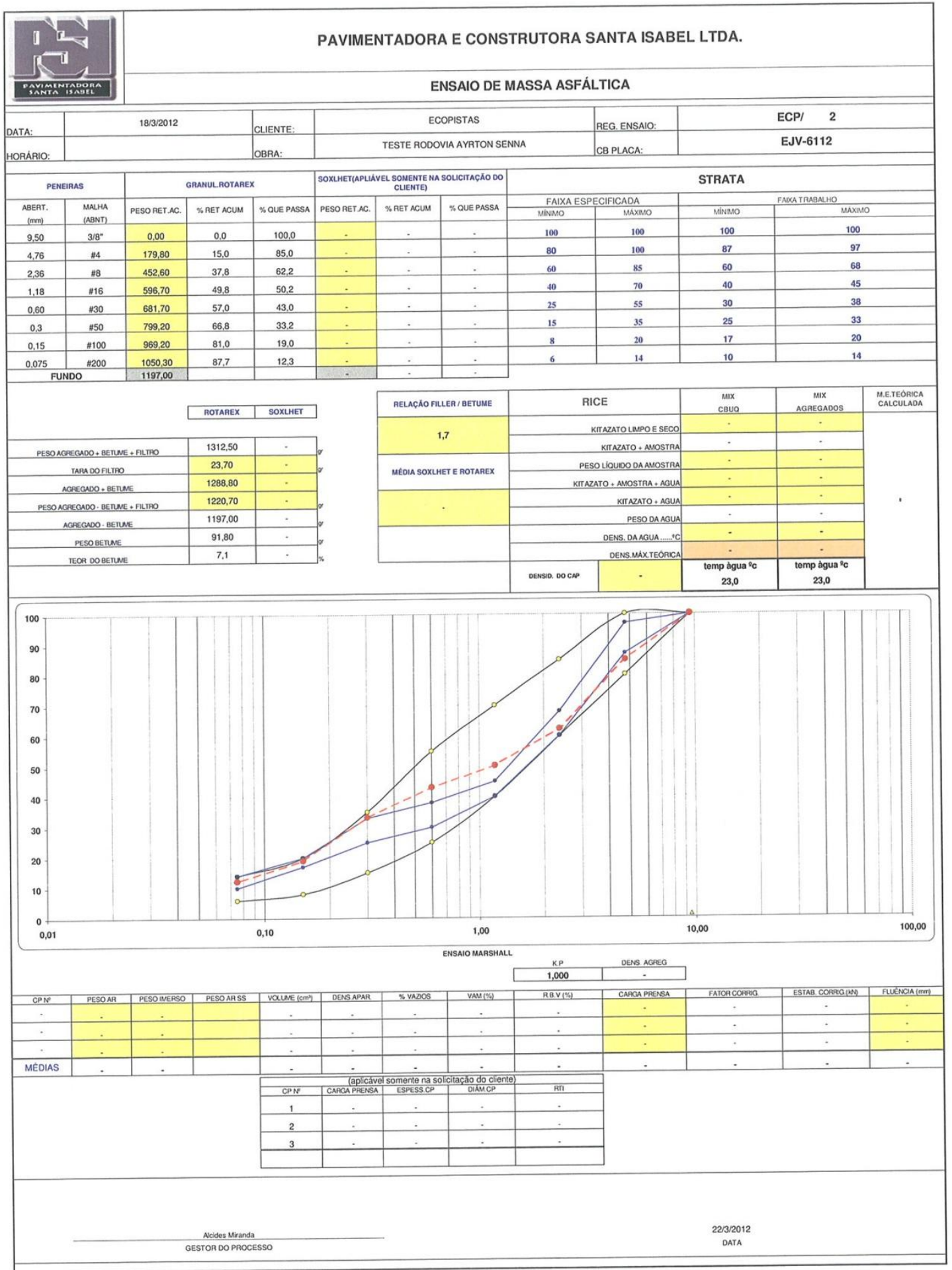




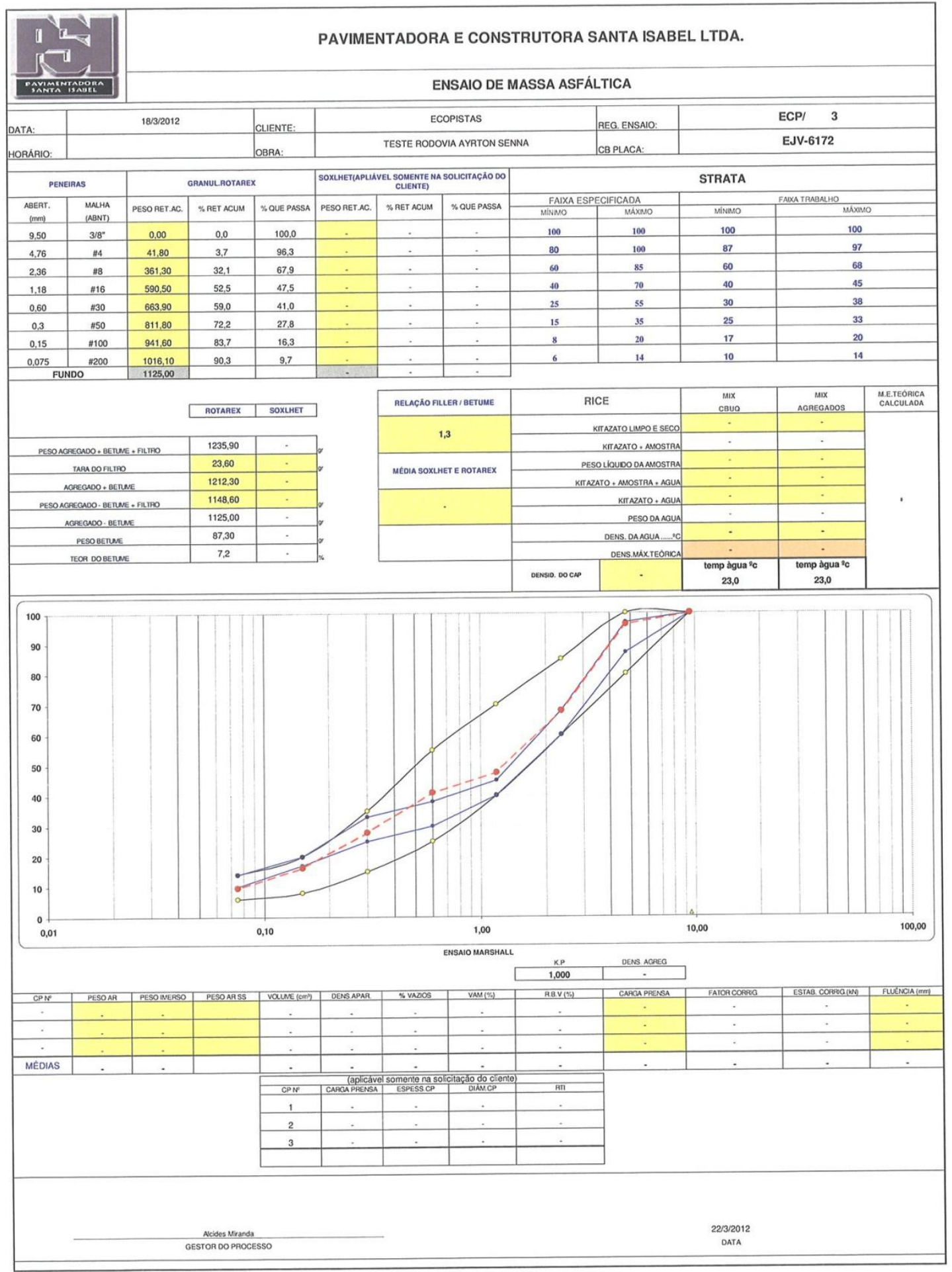




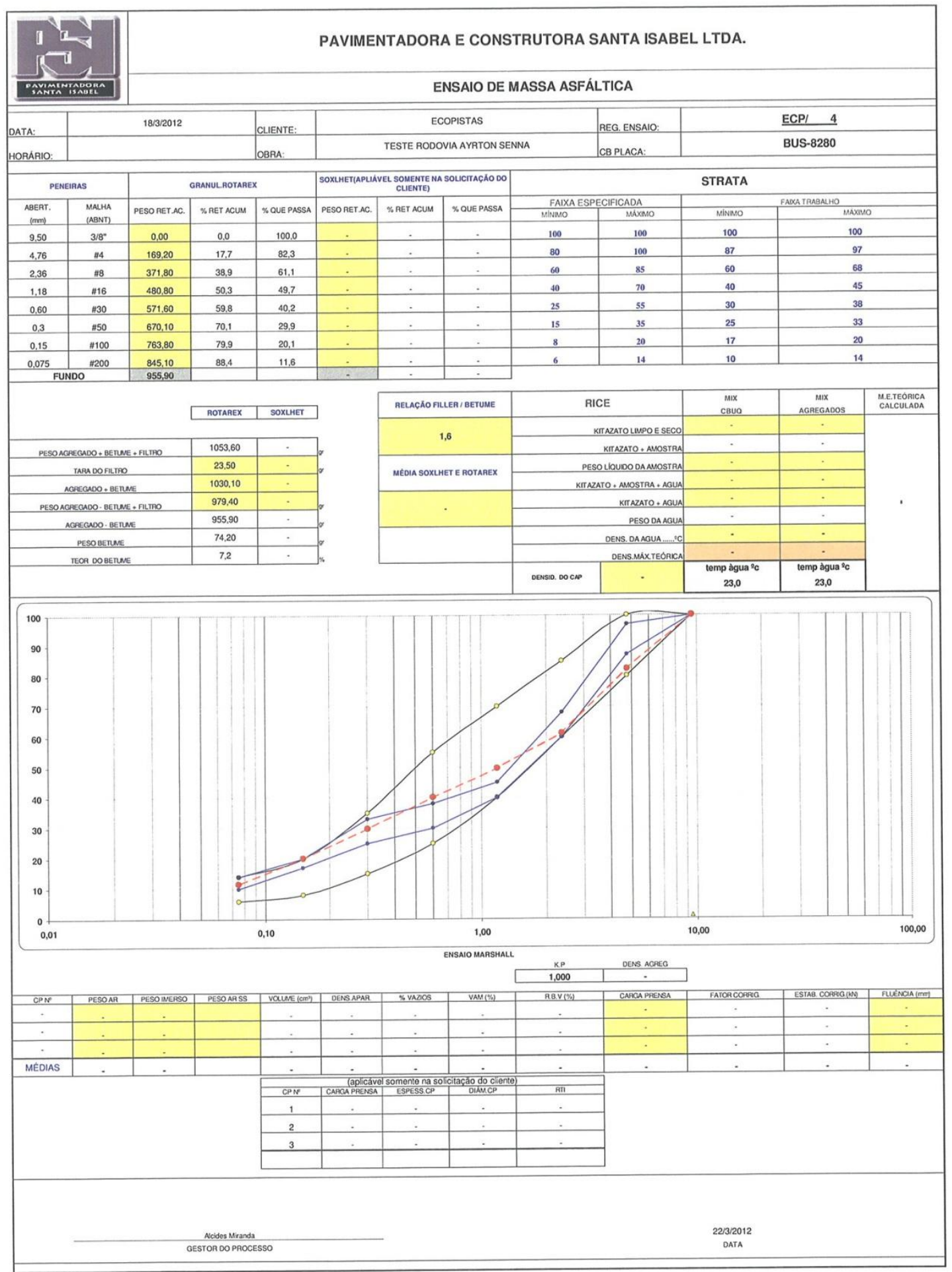




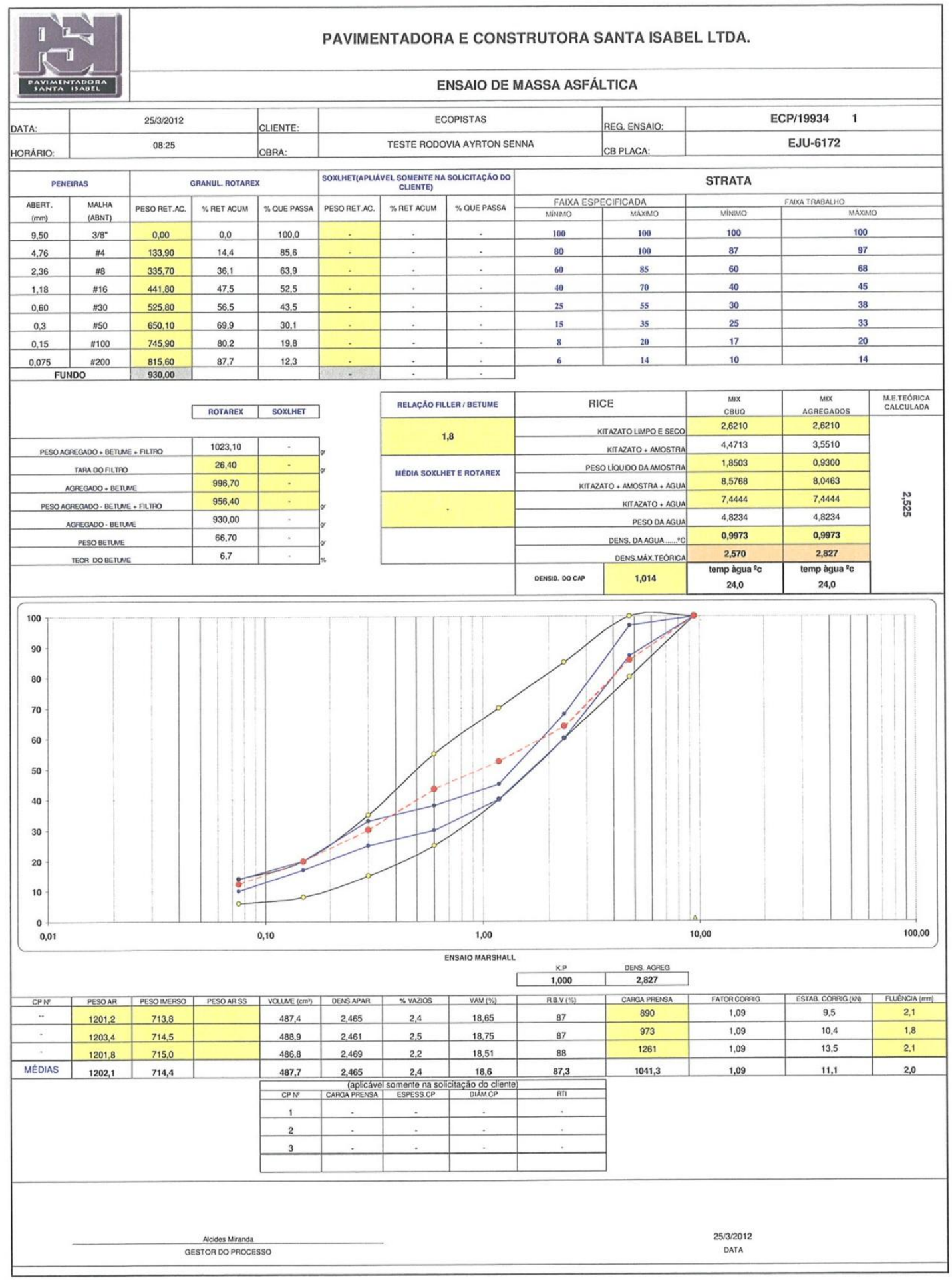

